Paisagem, Cartografia e Projeto: uma leitura da bacia hidrográfica do córrego Monjolinho em São Carlos, SP

Dissertação de mestrado

MARIA CECÍLIA PEDRO BOM DE LIMA

Universidade de São Paulo

Instituto de Arquitetura e Urbanismo

São Carlos, 2019

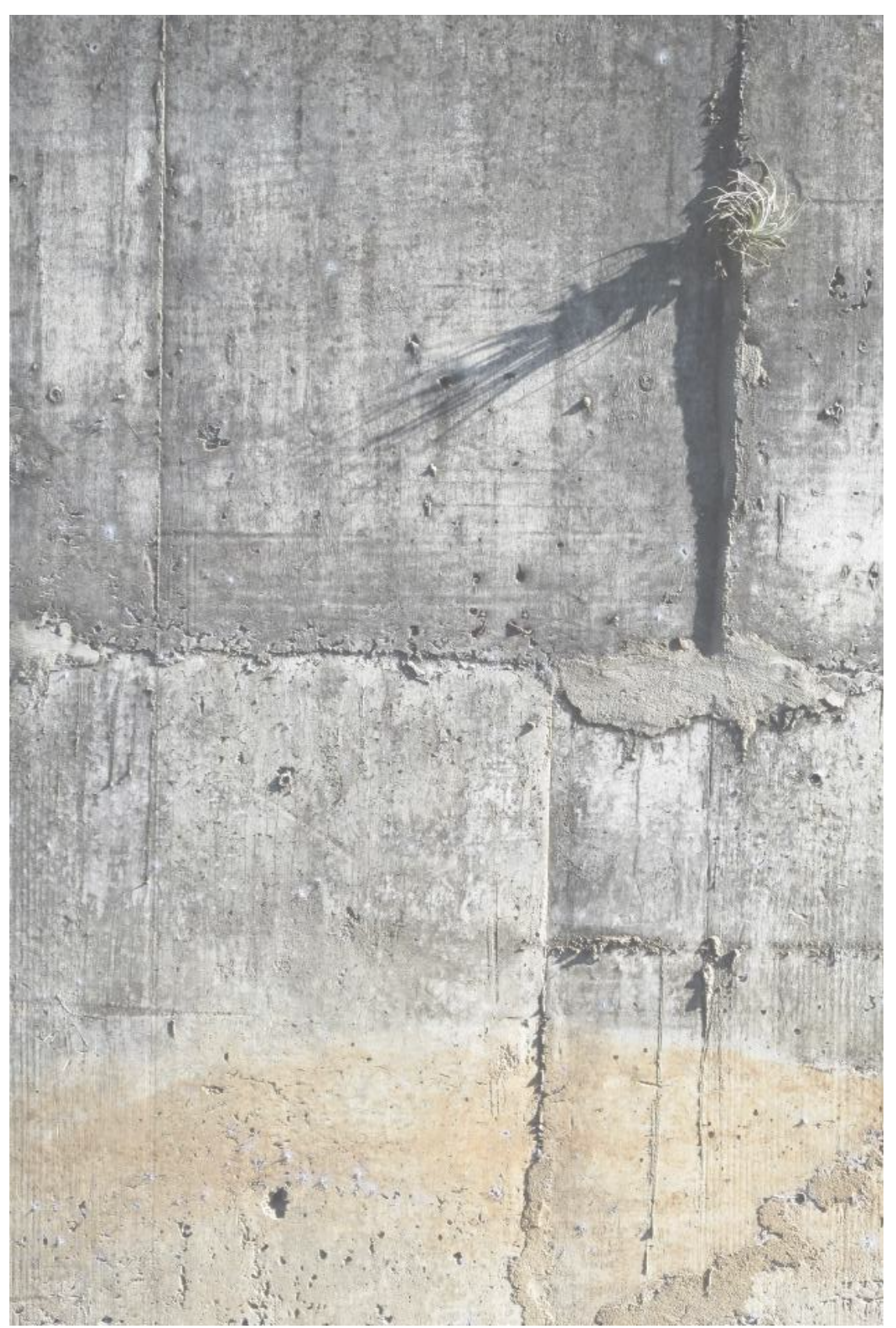



MARIA CECÍLIA PEDRO BOM DE LIMA

\section{Paisagem, Cartografia e Projeto: uma leitura da bacia hidrográfica do córrego Monjolinho em São Carlos, SP}

Versão Corrigida

Dissertação apresentada ao Programa de Pós Graduação em Arquitetura e Urbanismo do Instituto de Arquitetura e Urbanismo da Universidade de São Paulo para a obtenção do título de Mestre.

Área de concentração:Teoria e História da Arquitetura e do Urbanismo

Orientadora: Profa. Drạ. Luciana Bongiovanni Martins Schenk 


\section{AUTORIZO A REPRODUCAO TOTAL OU PARCIAL DESTE TRABALHO, \\ POR QUALQUER MEIO CONVENCIONAL OU ELETRONICO, PARA FINS DE ESTUDO E PESQUISA, DESDE QUE CITADA A FONTE}

Ficha catalográfica elaborada pela Biblioteca do Instituto de Arquitetura e Urbanismo com os dados fornecidos pelo(a) autor(a)

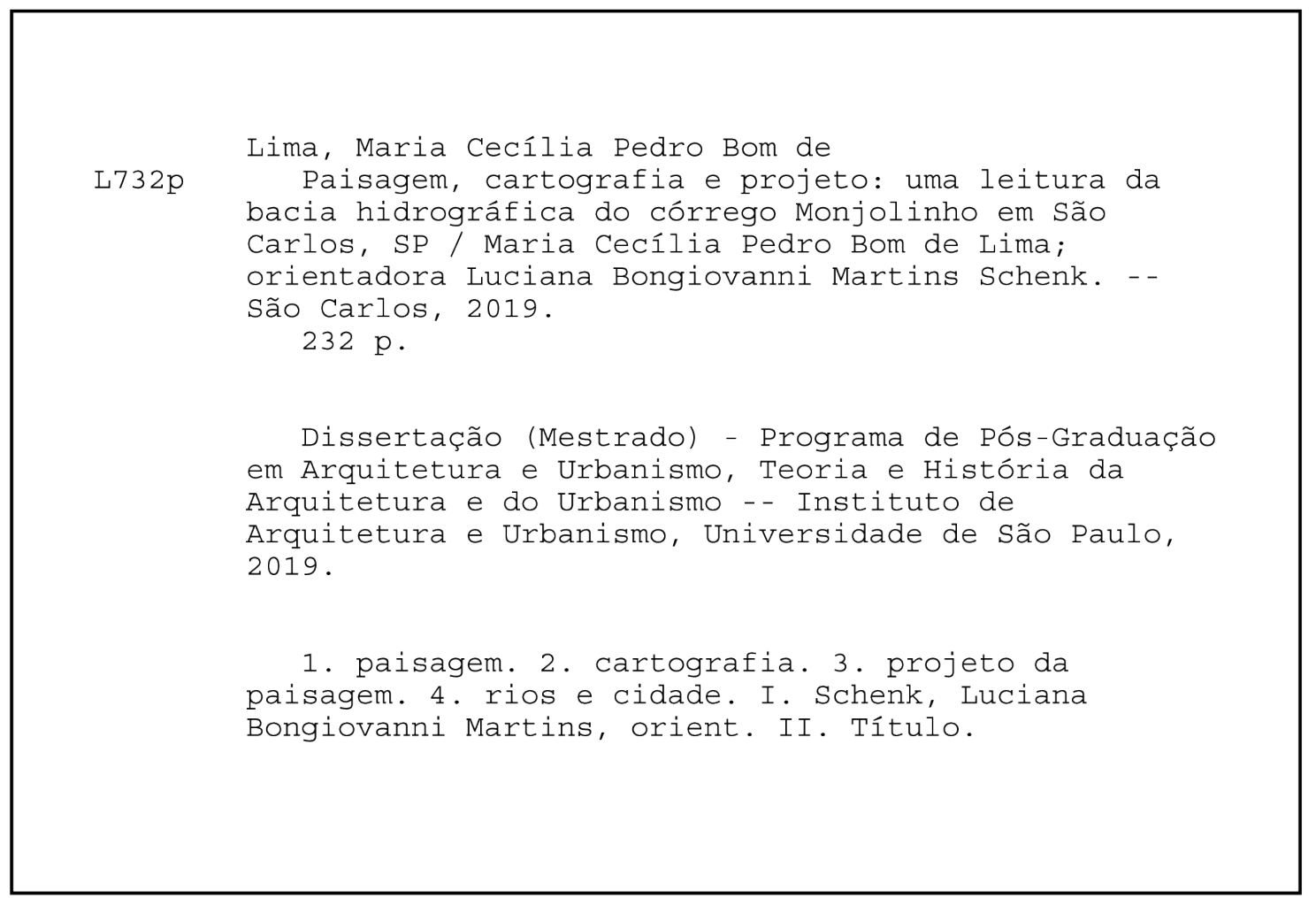

Bibliotecária responsável pela estrutura de catalogação da publicação de acordo com a AACR2:

Brianda de Oliveira Ordonho Sígolo - CRB - 8/8229 
Título da dissertação: "Paisagem, cartografia e projeto: uma leitura da bacia hidrográfica do córrego Monjolinho em São Carlos, SP".

Data da defesa: 14/06/2019

Orientador: Profa. Dra. Luciana Bongiovanni Martins Schenk

Comissão Julgadora:

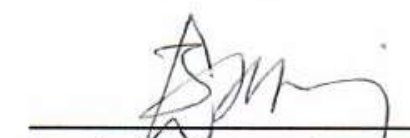

Profa. Dra. Luciana Bongiovanni Martins Schenk (IAU/USP)/

Prof. Dr. Luciano Bernardino da Costa (IAU/USP)

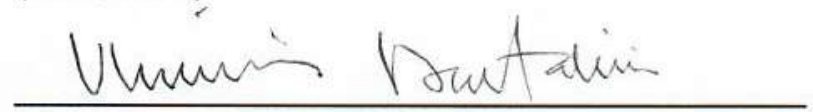

Prof. Dr. Vladimir Bartalini

(FAU/USP)

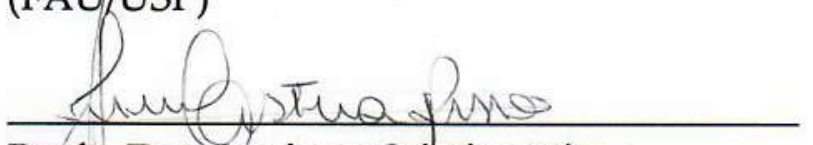

Profa. Dra. Luciene Cristina Risso

UNESP (Rio Claro)

Coordenador e Presidente da Comissão de Pós-Graduação do Programa de Pós-

Graduação em Arquitetura e Urbanismo: Prof. Dr. Tomás Antonio Moreira.
Não votante
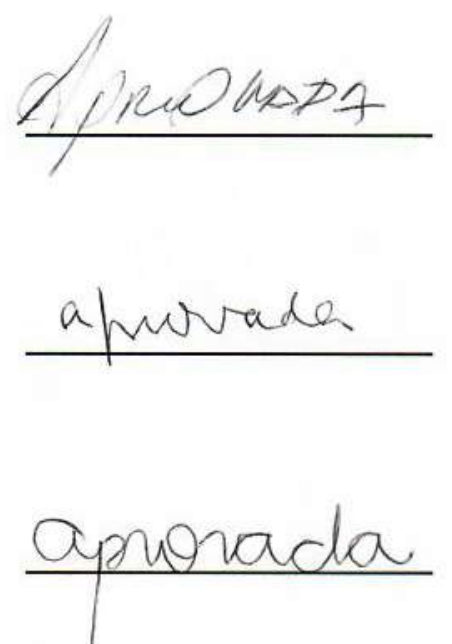



\section{AGRADECIMENTOS}

Agradeço à minha orientadora, a professora Luciana Schenk, pelo conhecimento compartilhado, pelas relevantes contribuições para minha formação desde a graduação e pela parceria constituída ao longo dos anos.

À Coordenação de Aperfeiçoamento de Pessoal de Nível Superior (CAPES) pelo auxílio financeiro concedido.

Ao Instituto de Arquitetura e Urbanismo, aos professores e funcionários da biblioteca e da secretaria de pós graduação que deram suporte ao desenvolvimento deste trabalho e ao grupo de pesquisa YBY. Agradeço em especial ao professor Luciano Costa pelas ricas conversas sobre fotografia.

Aos professores Vladimir Bartalini e Maria Franco por me receberem em suas disciplinas do Programa de Pós Graduação da FAUUSP, as quais consistiram em grandes constribuições para a presente pesquisa. À professora Luciene Risso por ter aceitado minha participação em sua disciplina do Programa de Pós Graduação em Geografia da Unesp de Rio Claro, que permitiu diálogos interdisciplinares instigantes. À professora Renata Bovo Peres (UFSCar) por ter possibilitado, em conjunto com Luciana, a organização do Grupo de Trabalho sobre os Parques Urbanos de São Carlos, do qual tive a oportunidade de participar durante o ano de 2018, enriquecendo o processo de pesquisa, bem como minha formação pessoal.

Aos amigos, em especial ao Guilherme, Eveline, Mariane e Marcos, pela companhia e pelos conselhos.

Aos meus pais Maria Lucia e Marcos César e minha irmã Ana Laura, cujo apoio foi imprescindível para a realização desse processo. 



\section{REsUmo}

LIMA, Maria Cecília Pedro Bom de. Paisagem, Cartografia e Projeto: uma leitura da bacia hidrográfica do Córrego Monjolinho em São Carlos, SP. Dissertação de mestrado. Instituto de Arquitetura e Urbanismo, Universidade de São Paulo, 2019.

Este trabalho propõe uma reflexão sobre a relação entre rios e cidade, considerando o processo de projeto em Arquitetura da Paisagem. Historicamente, delimitou-se uma relação conflituosa entre processos urbanos e processos naturais, resultante de um modo predominante de construir o espaço urbano, que interpreta o território segundo uma visão de sobrevoo e busca controlar os processos naturais pela técnica. Com isso, os cursos d'água foram identificados como obstáculos, tendo sua presença suprimida do cotidiano urbano. No entanto, essa lógica não é capaz de contemplar todos os aspectos da paisagem, a qual é constituída por manifestações imprevisíveis à leitura estritamente técnica. Trata-se das paisagens de margem, espaços indeterminados e caracterizados por processos efêmeros, que constituem o mundo vivido contemporâneo. Esta pesquisa identifica que a cartografia, entendida como método, consiste em uma estratégia capaz de abarcar a complexidade que define a noção de paisagem, incluindo no processo de projeto esses espaços que se colocam à margem da construção da cidade. Partindo de uma investigação sobre as noções de Paisagem e Cartografia, busca-se promover uma leitura sobre a bacia hidrográfica do Córrego Monjolinho na cidade de São Carlos, SP, segundo a perspectiva projetual, de modo a revelar paisagens que explicitam as diversas qualidades da relação entre rios e cidade.

Palavras-chave: paisagem; cartografia; projeto da paisagem; rios e cidade. 



\section{ABSTRACT}

LIMA, Maria Cecília Pedro Bom. Landscape, Cartography and Design: an interpretation on Monjolinho river basin in São Carlos, SP. Master dissertation. Instituto de Arquitetura e Urbanismo, Universidade de São Paulo, 2019.

This research proposes a critical consideration on the relationship between rivers and city and the design process in Landscape Architecture. A conflicting relationship between urban processes and natural processes has been delineated historically as a result from a predominant way of constructing urban space that interprets the territory according to a top-down approach and seeks to control natural processes by technique. This approach identifies rivers with obstacles and supresses their presence from the urban daily life. However this way of constructing cities is not able to control all aspects of the landscape which engages features that are unpredictable to the strictly technical approach. These aspects refer to transitional landscapes which are undetermined and characterized by the ephemeral processes of the contemporary lived world. This research considers cartography as a method capable of encompassing the complexity that defines the notion of landscape in order to include its indeterminated features in the design process. Starting from an investigation about the notions of Landscape and Cartography, the research intends to promote an interpretation on Monjolinho river basin in the city of São Carlos, SP according to landscape design process and intends to reveal landscapes that express the various qualities of the relation between rivers and city.

Keywords: landscape; cartography; landscape design; rivers and city. 



\section{LISTA DE FIGURAS}

Figura 1

$23 \mathrm{~K}$ | $200260 \mathrm{~m} \mathrm{E}$ | $7563671 \mathrm{~m} \mathrm{~S}(2017)^{1}$

Fonte: da autora.

Figura 2

$23 \mathrm{~K} \mid 199126 \mathrm{~m} \mathrm{E}$ | 7561842 m S (2017)

Fonte: da autora.

Figura 3 ... p. 104

Bacias hidrográficas no Município de São Carlos. Fonte: PMSC, 2011.

Figura 4 .................................................. p. 105 Principais córregos da bacia hisdrográfica do córrego Monjolinho.

Fonte: elaborado a partir de carta de hidrografia do IBGE e imagem do Google Earth, 2017.

Figura 5 ................................................. p. 110 Ruas em quadrícula próximas ao córrego Gregório. Fonte: acervo da Fundação Pró-Memória de São

1 A localização das fotografias produzidas pela autora estão indicadas pelo sistema de coordenadas UTM, datum WGS 84, retiradas do Google Earth, seguido pelo ano em que foi efetuado o registro fotográfico.
Carlos, 1989.

Figura 6

p. 110 Figura 14

p. 120

Enchente.

AEIs Ambientais do Plano Diretor de 2016.

Fonte: acervo da Fundação Pró-Memória de São Fonte: PMSC, 2016.

Carlos, sem data.

Figura 7 ....

Figura 15

Matéria do jornal A Folha de 01/09/1968.

Fonte: acervo da Fundação Pró-Memória de São Carlos, 1968.

Figura 8 ....

Matéria do jornal A Folha de 20/04/1968.

Fonte: acervo da Fundação Pró-Memória de São Carlos, 1968.

Figura 9 .....

Matéria do jornal A Folha de 24/07/1968.

Fonte: acervo da Fundação Pró-Memória de São Carlos, 1968.

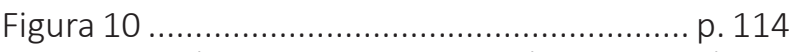
Construção de vias marginais no córrego Gregório.

Fonte: acervo da Fundação Pró-Memória de São Carlos, 1974.

Figura 11

Obras de galerias na Av. São Carlos.

Fonte: acervo

Figura 12

Ações previstas no TAC das Avenidas Marginais.

Fonte: elaborado a partir de informações do Relatório do Plano Municipal de Saneamento de São Carlos, 2012; carta de hidrografia da PMSC, 2015 e imagem do Google Earth.

Figura 13

AEIs Urbanas do Plano Diretor de 2005.

Fonte: PMSC, 2005 p. 114

de são p. 117

Intervenções previstas pelo Plano Diretor de Drenagem Urbana Ambientalmente Sustentável do Município de São Carlos.

Fonte: Secretaria Municipal de Obras Públicas de São Carlos, 2010.

Figura 16 p. 125

Enchente no bairro Lagoa Serena em 1975 (córrego Simeão)

Fonte: acervo da Fundação Pró-Memória de São Carlos, 1975.

Figura 17 .................................................. p. 125 Enchente em 1999 (encontro dos córregos Gregório e Mineirinho com Monjolinho)

Fonte: acervo da Fundação Pró-Memória de São Carlos, 1999.

Figura 18 p. 125 Enchente na avenida Getúlio Vargas em 1975 (córrego Simeão)

Fonte: acervo da Fundação Pró-Memória de São Carlos, 1968.

Figura 19 p. 126

Pontos suscetíveis a enchentes.

Fonte: elaborado a partir de carta de hidrografia do IBGE; imagem do Google Earth e informações de matéria do G1; (1) OSCIP Veredas; (2) A Folha Paulista, 2015; (3) G1/EPTV, 2013

Figura 20

p. 119

$23 \mathrm{~K}$ | $201075 \mathrm{~m} \mathrm{E} \mid 7565059 \mathrm{~ms}(2017$

Fonte: da autora. 
Figura 21

Sequência de paisagens.

Fonte: elaborado a partir de carta de hidrografia do IBGE e imagem do Google Earth.

Figura 22

$23 \mathrm{~K}$ | 200095 m E | 7563547 m S (2017)

Fonte: da autora.

Figura 23 .....

23 K | 200211 m E | 7563457 m S (2017)

Fonte: da autora.

Figura 24

23 K | 200134 m E | 7563340 m S (2017)

Fonte: da autora.

Figura 25 .....

23 K | 199976 m E | 7563198 m S (2017)

Fonte: da autora.

p. 140

Figura 26

23 K | 200323 m E | 7563816 m S (2017)

Fonte: da autora.

Figura 27

23 K | 200475 m E | 7563879 m S (2017)

Fonte: da autora.

Figura 28 .

23 K | 200256 m E | 7563747 m S (2017)

Fonte: da autora.

Figura 29

23 K | 200576 m E | 7564083 m S (2017)

Fonte: da autora.

Figura 30

$23 \mathrm{~K} \mid 200598$ m E | 7564419 m S (2017)

Fonte: da autora.
129 Figura 31

23 K | 199330 m E | 7562409 m S (2017)

Fonte: da autora.

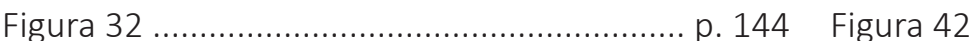

Fonte: da autora.

23 K | 199375 m E | 7562357 m S (2017)

Fonte: da autora.

Figura 34

Fonte: São Carlos Urgente, 2015.

Figura 35

Enchente na Rotatória do Cristo em 1999.

Fonte: acervo da Fundação Pró-Memória de São Carlos, 1999.

p. 141 Figura 36

Alguns espaços livres que cumprem a função projetada.

Fonte: elaborado a partir de imagem do Google Earth.

Figura 37

23 K | 200699 m E | 7564489 m S (2017)

p. 141 Fonte: da autora.

Figura 38

23 K | 199980 m E | 7562516 m S (2018)

p. 142 Fonte: da autora.

Figura 39 .....

23 K | 200181 m E | 7560893 m S (2017)

p. 143 Fonte: da autora.

Figura 40

23 K | 199929 m E | 7560818 m S (2017)

Fonte: da autora. p. 144 Figura 41

23 K | 200064 m E | 7563273 m S (2017)

Fonte: da autora.

23 K | 199873 m E | 7562987 m S (2017)

Fonte: da autora.

p. 145 Figura 43

23 K | 199874 m E | 7562954 m S (2017)

Fonte: da autora.

p. 145 Figura 44

$23 \mathrm{~K} \mid 199914$ m E | 7563104 m S (2017)

Fonte: da autora.

p. 145 p. 147

p. 150

p. 150

p. 151

Figura 45 ..................................................... p. 153 Alguns espaços livres que não cumprem a função projetada.

Fonte: elaborado a partir de imagem do Google Earth.

Figura 46 ................................................. p. 154 23 K | 199872 m E | 7564596 m S (2018)

Fonte: da autora.

Figura 47 p. 154

23 K | 199438 m E | 7563911 m S (2018)

Fonte: da autora.

Figura 48 p. 155

23 K | 200228 m E | 7563137 m S (2018)

Fonte: da autora.

Figura 49 p. 155

23 K | 199016 m E | 7561405 m S (2018) Fonte: da autora.

Figura 50

p. $14923 \mathrm{~K}|200211 \mathrm{~m} \mathrm{E}| 7563457$ m S (2017) Fonte: da autora. 
Figura 51 23 K | 200513 m E | 7564013 m S (2017) Fonte: da autora.

Figura 52 23 K | 200211 m E | 7563457 m S (2017) Fonte: da autora.

Figura 53 23 K | 200939 m E | 7564595 m S (2018) Fonte: da autora.

Figura 54 23 K | 201187 m E | 7565046 m S (2018) Fonte: da autora.

Figura 55 23 K | 201475 m E | 7565439 m S (2018)

Fonte: da autora.

Figura 56 23 K | 201475 m E | 7565439 m S (2018) Fonte: da autora.

Figura 57 23 K | 201096 m E | 7564882 m S (2018) Fonte: da autora.

Figura 58 23 K | 201289 m E | 7564808 m S (2017) Fonte: da autora.

Figura 59 23 K | 201081 m E | 7564961 m S (2018) Fonte: da autora.

Figura 60 23 K | 199547 m E | 7562807 m S (2018) Fonte: da autora.

p. 161

Figura 61 23 K | 198803 m E | 7561565 m S (2018)

Fonte: da autora. p. 158 Figura 62 23 K | 199011 m E | 7561411 m S (2018) Fonte: da autora.

p. 158 Figura 63

23 K | 201141 m E | 7564958 m S (2018) Fonte: da autora.

p. 158 Figura 64 23 K | 201098 m E | 7564849 m S (2017) Fonte: da autora.

p. 159 Figura 65 23 K | 205377 m E | 7564905 m S (2017) Fonte: da autora.

p. 159 Figura 66 23 K | 205377 m E | 7564905 m S (2017) Fonte: da autora.

p. 159 Figura 67 23 K | 201055 m E | 7564852 m S (2018) Fonte: da autora.

p. 160 Figura 68 23 K | 201075 m E | 7565049 m S (2018) Fonte: da autora.

p. 160 Figura 69 23 K | 201081 m E | 7564954 m S (2018) Fonte: da autora.

p. 160 Figura 70 23 K | 201142 m E | 7565238 m S (2018) Fonte: da autora.

Figura 71 $23 \mathrm{~K} \mid 198598$ m E | 7561549 m S (2018) Fonte: da autora.

Figura 72 23 K | 200987 m E | 7564759 m S (2017) Fonte: da autora. p. 161 Figura 73 ................................................ p. 167 23 K | 201013 m E | 7564793 m S (2017) Fonte: da autora.

p. 162 Figura $74 \ldots \ldots \ldots \ldots \ldots \ldots \ldots \ldots \ldots \ldots$ p. 167 23 K | 201144 m E | 7565231 m S (2018) Fonte: da autora.

p. 162 Figura $75 \ldots . . . \ldots \ldots \ldots \ldots . . . . .168$ 23 K | 201119 m E | 7564880 m S (2017) Fonte: da autora.

p. 163

igura 76 $23 \mathrm{~K} \mid 201119$ m E | 7564880 m S (2018) Fonte: da autora.

p. 163

Figura 77 23 K | 200872 m E | 7564467 m S (2018)

Fonte: da autora.

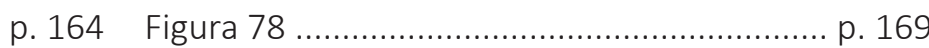
23 K | 200872 m E | 7564467 m S (2018) Fonte: da autora.

p. 164 Figura 79 23 K | 201096 m E | 7564882 m S (2017) Fonte: da autora.

p. 165 Figura 80 23 K | 201096 m E | 7564882 m S (2018) Fonte: da autora.

p. 165

Figura 81 p. 171 23 K | 201366 m E | 7565297 m S (2018) Fonte: da autora.

p. 166 Figura 82 K 201366 m E | 7565297 m S (2017) Fonte: da autora.

p. 166 Figura 83 23 K | 198610 m E | 7561597 m S (2018) Fonte: da autora. 
Figura 84 .....

23 K | 201366 m E | 7565297 m S (2018)

Fonte: da autora.

Figura 85

23 K | 201092 m E | 7564840 m S (2017)

Fonte: da autora.

Figura 86

$23 \mathrm{~K} \mid 199528$ m E | 7563635 m S (2018)

Fonte: da autora.

Figura 87

23 K | 201173 m E | 7565020 m S (2018)

Fonte: da autora.

Figura 88

23 K | 201019 m E | 7564749 m S (2018)

Fonte: da autora.

Figura 89

23 K | 201141 m E | 7564958 m S (2018)

Fonte: da autora.

Figura 90 .....

23 K | 200872 m E | 7564467 m S (2018)

Fonte: da autora.

Figura 91

23 K | 199204 m E | 7561613 m S (2018)

Fonte: da autora.

Figura 92

23 K | 201285 m E | 7564823 m S (2017)

Fonte: da autora.

Figura 93 ....

23 K | 200990 m E | 7564701 m S (2018)

Fonte: da autora.

Figura 94

$23 \mathrm{~K} \mid 200990$ m E | 7564701 m S (2018)

Fonte: da autora. p. 172

Figura 95

23 K | 199204 m E | 7561613 m S (2018)

Fonte: da autora.

p. 173 Figura 105

23 K | 199740 m E | 7563426 m S (2018)

Fonte: da autora.

p. 172 Figura 96

23 K | 199683 m E | 7562580 m S (2018)

Fonte: da autora.

p. 173 Figura 106

23 K | 199944 m E | 7563342 m S (2017)

Fonte: da autora.

p. 172 Figura 97

23 K | 198599 m E | 7561544 m S (2018)

Fonte: da autora.

p. 173 Figura 107

23 K | 199356 m E | 7563245 m S (2018)

Fonte: da autora.

p. 172 Figura 98

23 K | 201019 m E | 7564749 m S (2018)

Fonte: da autora.

p. 173

Figura 108

p. 172 Figura 99

Vistas

p. 175

Fonte: elaborado a partir de carta de hidrografia da PMSC e imagem do Google Earth.

Figura 100

23 K | 199864 m E | 7564623 m S (2018)

Fonte: da autora.

Figura 101

23 K | 200748 m E | 7564263 m S (2017)

Fonte: da autora.

Figura 102

23 K | 201144 m E | 7564441 m S (2018)

Fonte: da autora.

Figura 103 .....

23 K | 199352 m E | 7563994 m S (2018)

Fonte: da autora.

Figura 104

23 K | 200292 m E | 7563936 m S (2017)

Fonte: da autora.

p. 173

\section{Recortes.}

Fonte: elaborado a partir de carta de hidrografia da PMSC e imagem do Google Earth.

Figura 109

p. 183

Recorte 1.

Fonte: elaborado a partir de imagem do Google Earth e carta de áreas públicas, SMHDU, 2015.

Figura 110 ............................................... p. 184 23 K | 201346 m E | 7565347 m S (2017)

Fonte: da autora.

Figura 111

23 K | 201346 m E | 7565347 m S (2018

p. 184

Fonte: da autora.

Figura 112 p. 184

23 K | 201349 m E | 7565358 m S (2018)

Figura 113 .......

23 K | 201389 m E | 7565382 m S (2018) Fonte: da autora.

Figura 114

Recorte 2.

Fonte: elaborado a partir de imagem do Google

Earth e carta de áreas públicas, SMHDU, 2015.
Fonte: da autora. 
Figura 115 $23 \mathrm{~K}$ | $201121 \mathrm{~m} \mathrm{E}$ | 7565255 m S (2018) Fonte: da autora.

Figura 116 23 K | 201135 m E | 7565236 m S (2018) Fonte: da autora.

Figura 117 23 K | 201142 m E | 7565238 m S (2018) Fonte: da autora.

Figura 118 23 K | 201144 m E | 7565231 m S (2018) Fonte: da autora.

Figura 119 23 K | 201149 m E | 7565228 m S (2018)

Fonte: da autora.

Figura 120 $23 \mathrm{~K}$ | 201154 m E | 7565233 m S (2018)

Fonte: da autora.

Figura 121

Recorte 3

Fonte: elaborado a partir de imagem do Google Earth e carta de áreas públicas, SMHDU, 2015.

Figura 122 23 K | 201119 m E | 7564880 m S (2017

Fonte: da autora.

p. 192

Figura 123 23 K | 201108 m E | 7564877 m S (2017)

Fonte: da autora.

Figura 124 $23 \mathrm{~K} \mid 201119 \mathrm{~m} \mathrm{E}$ | 7564880 m S (2018) Fonte: da autora. p. 188 Figura 125 p. $192-193$ 23 K | 201098 m E | 7564869 m S (2017) Fonte: da autora.

p. 188 Figura 126 23 K | 201075 m E | 7565059 m S (2017) Fonte: da autora.

Figura 127

Recorte 4.

Fonte: elaborado a partir de imagem do Google

Earth e carta de áreas públicas, SMHDU, 2015.

Figura 128

23 K | 200932 m E | 7564570 m S (2017)

Fonte: da autora.

Figura 129

23 K | 201043 m E | 7564770 m S (2017)

Fonte: da autora.

Figura 130

23 K | 200939 m E | 7564595 m S (2018)

Fonte: da autora.

Figura 131

23 K | 200939 m E | 7564595 m S (2018)

Fonte: da autora.

Figura 132

$23 \mathrm{~K} \mid 200939$ m E | 7564595 m S (2018)

Fonte: da autora.

p. 192 Figura 133

23 K | 200949 m E | 7564610 m S (2018)

Fonte: da autora.

p. 192 Figura 134

Recorte 5.

Fonte: elaborado a partir de imagem do Google Earth e carta de áreas públicas, SMHDU, 2015. p. 193

Figura 135 ................................................... p. 200 23 K | 200926 m E | 7564562 m S (2018) Fonte: da autora.

Figura 136 ................................. p. 200

23 K | 200924 m E | 7564552 m S (2018)

Fonte: da autora.

Figura 137 p. 201 23 K | 200904 m E | 7564555 m S (2018) Fonte: da autora.

Figura 138

p. $19623 \mathrm{~K}|200920 \mathrm{~m} \mathrm{E}| 7564549$ m S (2018) Fonte: da autora.

Figura 139 p. 203

p. 196 Recorte 6

Fonte: elaborado a partir de imagem do Google Earth e carta de áreas públicas, SMHDU, 2015.

p. 197 p. 204 $23 \mathrm{~K}$ | 200636 m E | 7564450 m S (2017) Fonte: da autora.

p. 197 Figura 141 p. 204 $23 \mathrm{~K}$ | 200702 m E | 7564487 m S (2017) Fonte: da autora.

p. 197 Figura 142 .......................................... p. 205 23 K | 200700 m E | 7564322 m S (2017)

Fonte: da autora.

p. 197

Figura 143 $23 \mathrm{~K} \mid 200840$ m E | 7564450 m S (2018)

Fonte: da autora.

199 Figura 144 p. 207 Recorte 7.

Fonte: elaborado a partir de imagem do Google Earth e carta de áreas públicas, SMHDU, 2015. 
Figura 145

23 K | 200228 m E | 7563137 m S (2018)

Fonte: da autora.

Figura 146

23 K | 200270 m E | 7563140 m S (2018)

Fonte: da autora.

Figura 147

Recorte 8.

Fonte: elaborado a partir de imagem do Google

Earth e carta de áreas públicas, SMHDU, 2015.

Figura 148

23 K | 199683 m E | 7562580 m S (2018)

Fonte: da autora.

Figura 149

p. 212

$23 \mathrm{~K}$ | 199683 m E | 7562580 m S (2018)

Fonte: da autora.

Figura 150

p. $212-213$

23 K | 199920 m E | 7562879 m S (2017)

Fonte: da autora.

Figura 151

$23 \mathrm{~K} \mid 199547$ m E | 7562807 m S (2018)

Fonte: da autora.

Figura 152

23 K | 199514 m E | 7562815 m S (2018)

Fonte: da autora.

Figura 153

Recorte 9.

Fonte: elaborado a partir de imagem do Google Earth e carta de áreas públicas, SMHDU, 2015.

Figura 154 p. 216

$23 \mathrm{~K}$ | 199036 m E | 7561670 m S (2018)

Fonte: da autora.
Figura 155 ................................................... p. 217

23 K | 198792 m E | 7561571 m S (2018)

Fonte: da autora.

Figura 156

p. 217

23 K | 198595 m E | 7561537 m S (2018)

Fonte: da autora. 


\section{SUMÁRIO}

INTRODUÇÃO

1 - Paisagem, cartografia e projeto

PAISAGEM

Uma ideia polissêmica

Entre objetivo e subjetivo

Novas paisagens: à margem

CARTOGRAFIA

Ciência e arte: do contato à ruptura

Novas cartografias, novas articulações com a arte

PROJETO

Projetar a paisagem na contemporaneidade

Uma proposta de estratégia metodológica de projeto da Paisagem

2 - RIOS E CIDADE, ENTRE CONFLITO E CONGRUÊNCIA

A CONSTRUÇÃO DA RELAÇÃO ENTRE RIOS E CIDADES

A construção de um conflito

Alternativas para planejar e construir a cidade

Releituras de paisagens

SÃO CARLOS E MONJOLINHO

Caracterização de São Carlos

A urbanização de São Carlos: do café à indústria 
Aceleração da urbanização e industrialização de São Carlos

A crescente expansão periférica e a elaboração de planos

DESCOBRINDO PAISAGENS

Uma sequência de paisagens $\quad 131$

Categorias e desdobramentos $\quad 135$

\section{RECORTES}

181

Potenciais paisagens

181

Recorte 1: uma ponte sobre o córrego $\quad 182$

Recorte 2: um quintal 186

Recorte 3: contraste de escalas $\quad 190$

Recorte 4: confinamento 194

Recorte 5: a Avenida e a Alameda 198

Recorte 6: ponto de inflexão 202

Recorte 7: uma praça caminho 206

Recorte 8: duas vertentes $\quad 210$

$\begin{array}{ll}\text { Recorte 9: memória } & 214\end{array}$

$\begin{array}{ll}\text { CONSIDERAÇÕES FINAIS } & 218\end{array}$

REFERÊNCIAS BIBLIOGRÁFICAS 224 


\section{INTRODUÇÃO}

A paisagem consiste em tema complexo, cuja investigação envolve resgatar sua dimensão multidisciplinar, relacionada às questões que explicitaram modos de interpretar o mundo, característicos de cada época. A paisagem se refere às heranças e costumes de uma sociedade, ao mesmo tempo em que traduz processos inventivos, concepções em constante elaboração, inseridas em um mundo em transformação permanente. Entendida como construção cultural (BERQUE, 1994; BESSE, 2014), a paisagem é apreendida através do conjunto de elementos que testemunham material e simbolicamente a relação entre o ser humano e a natureza em seus diversos aspectos.

É essencial ter em mente essa pluralidade que engendra a noção de paisagem ao refletir acerca do projeto em Arquitetura da Paisagem, que sempre lidou com a relação entre ser humano e natureza, de acordo com concepções específicas sobre o que seria essa natureza em distintas épocas, presentes nas reflexões sobre a paisagem. Tais reflexões mostram que a ideia de natureza não se limita à noção de meio ambiente natural.

Esse campo de atuação trabalha com aquilo que a sociedade tem contato direto de maneira ininterrupta, o mundo vivido. Considera-se que o paisagista busca conhecer os aspectos objetivos e subjetivos que constituem a paisagem, para propor intervenções que dialogam com o contexto existente, mas também, que desencadeiam novas leituras que tornam visíveis, enquanto paisagens, certas composições que passam despercebidas, graças às leituras habituais do cotidiano, ou graças aos obstáculos impostos por uma cultura dominante que não valida o valor paisagístico de certos elementos.

Em Arquitetura da Paisagem, a investigação sobre a paisagem que considera um processo histórico de constituição, acompanhada pelo propósito de criação de novas paisagens, pode ancorar propostas de construção da cidade alternativas aos modelos hegemônicos que simplificam e esvaziam a paisagem e que já foram alvo de inúmeras críticas. Tais modelos correspondem principalmente aos esquemas utilitaristas concebidos na primeira 
metade do século XX. Referem-se a um processo de projeto que, segundo uma visão de sobrevoo distanciada das singularidades do território, pretende organizar a cidade e controlar os processos naturais e sociais pela técnica.

Embora exista um amplo questionamento sobre esses modelos pela historiografia da Arquitetura e Urbanismo, ainda é possível identificar nas cidades contemporâneas o prolongamento de suas lógicas. Somamse a isso as ações pautadas prioritariamente pelas lógicas do mercado do contexto atual de financeirização da economia, que renovam tais lógicas e estabelecem um cenário conflituoso com as propostas que visam reconstituir as paisagens ditas naturais ou pretendem alcançar um equilíbrio entre cidade e natureza. Aspectos ambientais, econômicos, políticos e socioculturais, em conjunto com a perspectiva de projeto e planejamento, corroboram a constituição de paisagens complexas, que explicitam a tensão resultante de intencionalidades diversas e contraditórias.

Atualmente, as cidades apresentam situações em que o retorno a um estado natural (primordial) da paisagem é improvável (HOUGH, 1984)ํ. Mesmo que as abordagens segundo o viés ecológico, centradas na busca pelo funcionamento equilibrado dos processos naturais, sejam essenciais no contexto contemporâneo, o projeto da paisagem não se esgota nessa direção e se estende à relação ampla entre ser humano e mundo. A paisagem não está necessariamente vinculada a um território naturalizado que se contrapõe à ação humana. Ela consiste no meio pelo qual as práticas do ser humano alteram o território e vice-versa (BERQUE, 2004). As paisagens podem estar presentes tanto em registro naturalizado como completamente artificioso.

Os cursos d'água podem ser interpretados como lugares exemplares para se pensar essas paisagens, pois articulam processos urbanos e naturais. Os rios e córregos revelam as lógicas que conformaram o espaço urbano e reúnem concreta e simbolicamente testemunhos da construção da relação entre natureza e cidade. Nesse sentido, a rede hídrica apresenta o potencial de evidenciar questões ambientais e socioculturais que podem orientar o desenvolvimento de projetos no campo da Arquitetura da Paisagem.

1 Existem alguns exemplos pelo mundo de obras de renaturalização, como o parque do rio Cheonggyecheon em Seul, Coreia do Sul, no entanto, evidencia-se o registro de artifício. 
O trabalho de identificar essas ações e, em especial, suas cicatrizes e vestígios, mostra-se complexo e necessário para se pensar o projeto da paisagem, considerando seu significado múltiplo, que envolve as dimensões técnica, cultural e estética.

A paisagem participa do cotidiano das pessoas e é fundamental reconhecer que seus significados e formas não estão relacionados somente a funções e à instrumentalidade. Identificada como meio onde se realiza a vida, envolve apreensões diversas, vinculadas tanto a sensações provocadas pelo que é concreto, como percepções associadas a significados, impressões, lembranças, identidades. Acessar essa diversidade de apreensões é o que torna o projeto da paisagem desafiador, pois implica identificar uma estratégia metodológica que abrigue tal complexidade, sem reduzi-la e esvazia-la.

Parte-se do princípio de que o processo de projeto da paisagem tem a qualidade de tornar apreensíveis experiências que se encontram em estado de potência e que passam despercebidas em meio aos processos cotidianos e que são suplantadas por visões culturais hegemônicas. No contexto contemporâneo, a investigação que pretende revelar paisagens encontra um campo amplo nas chamadas paisagens de margem, que não estão somente nas bordas da cidade, mas consistem naqueles lugares que foram desconsiderados ou abandonados pelas lógicas de produção do espaço urbano. São supostamente genéricas e invisíveis à leitura habitual da cidade, seja pela ausência de funções, ou pelo caráter de abandono. Se interpretados enquanto paisagens, esses espaços fazem emergir qualidades elementares do mundo vivido, da existência urbana e sua relação com a natureza: a efemeridade, a intagibilidade, a invisibilidade (NOGUÉ, 2008). São paisagens que se manifestam nas frestas entre espaços funcionalizados e sua existência é cambiante e apreensível fora (ou por baixo) dos ritmos produtivos (CERTEAU, 2007; CARERI, 2013). São paisagens que se referem à realidade contemporânea, mas que não recebem valor paisagístico de um olhar historicamente consolidado.

Frente à noção complexa de paisagem e seu projeto, questiona-se qual ferramenta e operação seriam adequadas a esse processo de criação que pretende lidar com aspectos tão diversos, descobrindo e revelando paisagens latentes. Mostra-se essencial a dissolução de concepções pré-estabelecidas que não são condizentes com o contexto atual e predominante. 
Diante disso, identifica-se na cartografia uma possibilidade. Mais do que representação gráfica do território, ela pode ser entendida como um modo de conhecer e intervir no território (BESSE, 2014) e, a partir do momento em que é entendida como método (PASSOS; KASTRUP; ESCÓSSIA, 2015), contribui para um processo de projeto cujas escolhas articulam distintos aspectos de uma realidade. A cartografia enquanto estratégia metodológica tem como questão nevrálgica a inserção e participação do observador no mundo observado. Articular cartografia e projeto da paisagem significa escapar de uma abordagem que sobrevoa o território e, de cima, define ações frequentemente pautadas por generalizações.

Partindo da exploração teórica sobre os temas da paisagem e da cartografia, que articulados, engendram o tema do projeto, esta pesquisa direciona o olhar para um objeto empírico, o território da bacia hidrográfica do córrego Monjolinho, na cidade de São Carlos, localizada no interior do Estado de São Paulo. Propõe-se a leitura desse território, orientada segundo a investigação do processo de construção dessa paisagem e segundo a descrição de sua existência no presente. Ao articular essas duas perspectivas, busca-se identificar lugares potenciais que explicitam a experiência diversificada contida na relação entre rios e cidade. Esse conjunto de espaços livres é evidenciado a partir de uma exploração do território segundo o Método Cartográfico, considerando as múltiplas dimensões que a ideia de paisagem recolhe do contexto da cidade e identificando no caminhar e no registro fotográfico, práticas que dão acesso às paisagens do mundo vivido.

A investigação sobre da relação entre rios e cidade se mostra relevante para a reflexão acerca do projeto da paisagem, na medida em que tal relação consiste na materialização de processos que caracterizam uma construção histórica, bem como revela a presença de espaços que se mantém à margem desses processos, viabilizando outros modos de experiência paisagística que escapam às leituras habituais. Reconhece-se nessa variedade de experiências o fio condutor para a identificação de um conjunto de espaços que contribuam para a fruição das paisagens da cidade, considerando seus múltiplos aspectos, seja como paisagens historicamente reconhecidas, seja como paisagens que não participam das narrativas oficiais. A apreensão dessa variedade seria possivel segundo uma estratégia metodológica de projeto que se aproxima do lugar e que não se restringe a concepções pré-estabelecidas e dominantes. 
O Capítulo 1 deste trabalho apresenta as bases teóricas consideradas para o desenvolvimento de uma estratégia metodológica para o projeto em Arquitetura da Paisagem. Para tanto, dois temas são identificados como nucleares para essa abordagem. O primeiro deles diz respeito à polissemia da ideia de Paisagem, que transita entre objetividade e subjetividade e abarca desde as formas estéticas de representação até a experiência das atuais paisagens de margem. O segundo tema consiste nas questões trazidas pela historiografia sobre a Cartografia, entendida não só como forma de representação e quantificação do território segundo uma visão de sobrevoo, mas compreendida, sobretudo, como método que promove o conhecimento da paisagem segundo uma aproximação e um contato direto com o mundo vivido. O entrelaçamento desses dois temas, ambos relacionados a modos de ver e conceber o mundo, constrói a base teórica para se pensar o Projeto da paisagem no contexto contemporâneo, considerando as transformações das intenções que nortearam as disciplinas de Arquitetura e Urbanismo, as quais, primeiramente, seguiram propósitos de ordenamento do território e buscaram o controle da natureza pela técnica, sendo posteriormente questionadas pelo conteúdo pautado na generalização e simplificação do cotidiano urbano. Os três temas, a Paisagem, a Cartografia e o Projeto, são permeados pelo campo artístico que, em diversos momentos, contribuiu para a constituição de modos de ver o mundo, criando instabilidades e promovendo a invenção de novos olhares e modos de intervir na paisagem.

O Capítulo 2 confronta as bases teóricas com o estudo do fenômeno, isto é, a relação entre a cidade de São Carlos e seus cursos hídricos, tendo em vista potenciais paisagens. Primeiramente, discorre-se sobre a relação entre rios e cidades, segundo a abordagem de autores que descrevem de maneira crítica o conflito entre cidade e natureza instituído pelas técnicas convencionais, que, vinculadas a contextos específicos, impermeabilizam o solo e ocultam as águas com tubulações subterrâneas, tornando invisíveis os processos naturais em meio urbano. Em seguida, são apresentadas reflexões sobre as proposições de planejamento e projeto urbano emergentes que passaram a buscar o equilíbrio entre processos urbanos e processos naturais e proposições que buscam pensar o projeto da paisagem para além do registro ecológico. Diante destas questões, é apresentado o processo de urbanização de São Carlos, apontando momentos representativos da relação entre a rede hídrica e a cidade, que traduzem os valores e agentes predominantes na constituição da paisagem.

O Capítulo 3 apresenta relatos sobre as paisagens do Córrego Monjolinho. Trata-se de uma leitura do 
território estudado, uma cartografia elaborada segundo a articulação de imagens e narrativas. Pretende-se, com esses relatos, complementar o estudo sobre o histórico de construção da relação entre córregos e a cidade de São Carlos, para identificar, a partir desse recorte, as diversas qualidades dessa paisagem no momento presente, que ultrapassam as leituras habituais e não se limitam ao viés ecológico do projeto da paisagem. Por meio de fotografias e narrativas, propõe-se indicar e revelar potenciais paisagens que possam compor um conjunto de espaços livres articulados pela rede hídrica da bacia do Córrego Monjolinho. 


\section{1 - Paisagem, cartografia e projeto}

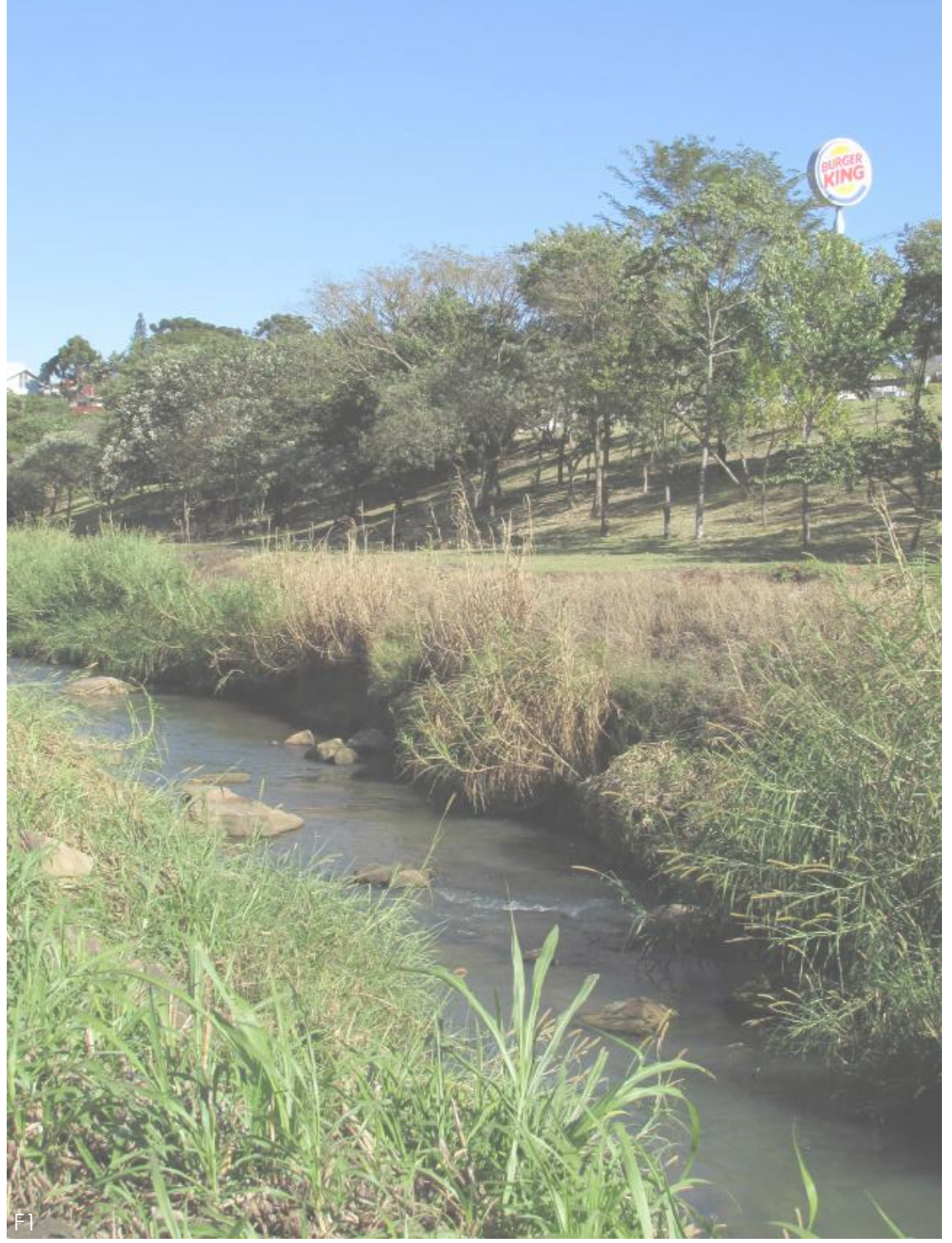




\section{PAISAGEM}

\section{Uma ideia polissêmica}

Paisagem é uma ideia complexa que envolve distintos campos disciplinares e suas respectivas abordagens específicas e depende de cada época e seus valores. Diversos fatores contribuem para a constituição de paisagens, como questões socioculturais, políticas, econômicas e técnicas que, de modo geral, constroem modos de ver (e viver) o mundo (BESSE, 2014).

Considera-se relevante especificar o significado do termo para a Arquitetura da Paisagem de modo a refletir sobre qual seria o objeto de intervenção desse campo e como tal processo pode ser realizado. Uma investigação desse tipo busca explicitar que a intervenção no mundo vivido não depende apenas de lógicas utilitárias e não envolve isoladamente a dimensão objetiva ou subjetiva da paisagem. A articulação entre objetividade e subjetividade, vinculadas ao aspecto cultural, traz importantes contribuições para as ações de leitura e intervenção que fazem parte do campo projetual.

Em Arquitetura e Urbanismo, frequentemente são adotadas as definições objetivas de paisagem, elaboradas em outros campos disciplinares, que a definem como um conjunto de elementos concretos que testemunham a passagem do tempo e a sobreposição de camadas (SANTOS, 2002) ou como elementos constituintes de um ecossistema, os quais necessitam de determinadas condições para seu funcionamento adequado (SPIRN, 1995; HOUGH, 1998)1. Compreender a paisagem segundo esses vieses implica no risco de intervir somente em sua perspectiva ambiental, ou de lidar com a paisagem de modo incompleto, sem explorar questões de percepção e

1 As abordagens de Anne Spirn e Michael Hough geralmente são lidas como referências para a concepção da paisagem enquanto ecossistema, vinculada à ecologia. Porém, é importante destacar que as questões trazidas por esses autores não se esgotam nesse viés sendo que percorrem discussões sobre a qualidade subjetiva da paisagem, no sentido de identificar valores e modos de percepção da natureza pela população das cidades. Inclusive, Anne Spirn declara sua intenção de se redimir por sua abordagem por demais pragmática que caracteriza o livro "The granite garden" (1995), e afirma trazer a dimensão poética em sua obra "The language of landscape" (1998). 
significado. As abordagens objetivas parecem desconsiderar fatores efêmeros e incertos que, como será exposto, são partes constituintes do mundo vivido, logo, da própria paisagem.

Tais definições objetivas tomam empréstimo de ideias desenvolvidas em parte da geografia e ecologia. De fato, são conceitos essenciais para se promover intervenções nas paisagens, no entanto, necessitam de uma complementação.

De forma paralela, as concepções estritamente subjetivas da paisagem a consideram como objeto estético e como representação, correndo o risco de eleger uma leitura dominante que suplanta as múltiplas experiências que são pouco reconhecidas pela cultura hegemônica. Além disso, trata-se de uma interpretação restrita ao campo da história da arte, que também parece pouco suficiente para se pensar o projeto paisagístico que se depara com realidades divergentes das narrativas "oficiais".

No contexto em que o discurso científico predomina na definição do que seria a paisagem, mostrase essencial resgatar sua dimensão de experiência estética, no sentido de abarcar suas "tonalidades afetivas" (BARTALINI, 2013a, p. 81), que estão relacionadas a uma imbricação entre o ser humano e o mundo, entre aspectos subjetivos e objetivos da existência.

Reflexões realizadas em diversos campos como filosofia, história, psicologia, na geografia de matriz cultural, entre outros, trazem ideias relevantes para Arquitetura e Urbanismo, ampliando a noção de Paisagem e as perspectivas de seu projeto.

Percorrendo o trabalho de diversos autores que resgatam o caminho histórico que caracteriza a ideia de Paisagem, é possível identificar uma questão comum que se coloca como central: a paisagem diz respeito, sobretudo, a modos de ver e representar (ou apresentar) o mundo, em diálogo com os valores construídos pela sociedade; é a relação entre o mundo e a humanidade. E essa relação acompanha as transformações que caracterizam as épocas e inclui, de modo concomitante, interações objetivas e subjetivas (BESSE, 2014).

Diante da multiplicidade de abordagens, a articulação entre as distintas concepções de paisagem é proposta 
por Jean Marc-Besse (2014), que promove uma reflexão acerca do tema em seu ensaio "As cinco portas da paisagem", no qual apresenta "cinco problemáticas paisagísticas que coexistem no pensamento contemporâneo e que não se superpõem (...), embora possam ser, às vezes, articuladas umas às outras" (BESSE, 2014, p. 12): a paisagem como representação cultural e social; território fabricado e habitado; meio ambiente material e vivo das sociedades humanas; experiência fenomenológica e projeto. Essas cinco formas de compreender a paisagem perpassariam a teoria e prática do arquiteto da paisagem, os quais não se limitariam a um conjunto específico de saberes.

... essas diferentes abordagens podem se encontrar, ou até se sobrepor, num mesmo autor, e a fortiori neste operador da complexidade que é o paisagista. Efetivamente, este último está constantemente às voltas com expectativas estéticas (inclusive as próprias) e horizontes morais ou políticos, mas também com as realidades materiais e estruturais específicas das localizações em que intervém, e da mesma forma com os afetos particulares suscitados pela experiência sensível dos lugares em que se encontra (BESSE, 2014, p. 64).

Desse modo, um dos desafios colocados para o trabalho com a paisagem no contexto contemporâneo é identificar a que ela se refere; o que são as paisagens sobre as quais podemos falar na cidade contemporânea, considerando as questões socioculturais, estéticas e técnicas abarcadas.

Esse questionamento pode ser acompanhado pela descrição da transformação da ideia de paisagem, cujo entendimento ocidental inicia-se nas formas de representação do mundo renascentista, até alcançar a contemporânea percepção das paisagens de margem. Ao longo desse percurso, é relevante destacar a imbricação das dimensões objetivas e subjetivas que definem a ideia de paisagem.

\section{Entre objetivo e subjetivo}

A história da arte reconhece que a origem da noção de paisagem no Ocidente localiza-se no período do Renascimento e diz respeito, antes de tudo, a um discurso, uma representação (BESSE, 2006; BERQUE, 1994). Segundo Jean-Marc Besse (2006), a paisagem definida pelo campo artístico pertencente a esse contexto 
consiste em uma construção subjetiva de caráter estritamente estético. Tendo como principal expressão a pintura de paisagens, ela se define essencialmente pelo domínio visual, relacionado a uma atitude contemplativa desinteressada.

Besse afirma que essa concepção estética da paisagem, vinculada ao discurso e à subjetividade, já era questionada por posturas mais objetivas desde o século XVII, contexto em que a cartografia e a pintura se apresentavam como duas ferramentas de representação que se articulavam num esforço de descrição do mundo. Tais posturas objetivas centravam-se na concepção da paisagem enquanto materialidade que deveria ser observada e descrita. Mesmo que sua descrição gerasse formas subjetivas de representação e narratividade, a paisagem em si existia em sua concretude e era objeto de interesse do conhecimento científico.

A visão objetiva da paisagem se sobressai justamente quando ela é identificada com um discurso científico. Tal discurso se faz presente no desejo pela descoberta do mundo, manifestado desde o período renascentista, bem como nos propósitos de organização e projeto desse mundo, em atendimento às necessidades humanas. A objetividade da paisagem estaria, portanto, em sua concretude e instrumentalidade. Nesse sentido, em "As cinco portas da paisagem", Besse apresenta a paisagem enquanto objetividade em duas "portas": território fabricado e habitado; meio ambiente material e vivo das sociedades humanas.

Na primeira dessas duas "portas", da paisagem enquanto território fabricado e habitado, o autor se apoia nas concepções do historiador John Brinckerhoff Jackson (1909- 1996), que considera a paisagem como uma construção cultural em seu sentido material, resultado de ações planejadas ou inconscientes:

É verdade que a paisagem também é uma maneira de ver e imaginar o mundo. Mas é primeiramente uma realidade objetiva, material, produzida pelos homens. Toda paisagem é cultural, não essencialmente por ser vista por uma cultura, mas essencialmente por ter sido produzida dentro de um conjunto de práticas (econômicas, políticas, sociais), e segundo valores que, de certa forma, ela simboliza (BESSE, 2014, p. 30).

Tal concepção dialoga com o campo da geografia, que teve Alexander von Humboldt (1769 - 1859) como um dos pioneiros que contribuíram para sua constituição enquanto disciplina no século XIX. Em sua teoria e prática, apresentava a paisagem enquanto objetividade, referente a um mundo natural a ser investigado e descrito, isto 
é, uma fisionomia. Embora Humboldt apresentasse uma concepção subjetiva de paisagem em complementação à sua materialidade ${ }^{2}$, é a dimensão objetiva que parece predominar nos desdobramentos da disciplina, isto é, na consolidação da chamada geografia física e nos primórdios da geografia cultural.

A geografia cultural alemã, no final do século XIX e início do século XX, introduziu nas discussões sobre a paisagem, o papel do homem e seus valores na configuração do mundo ${ }^{3}$. Buscava-se entender a cultura através dos utensílios e técnicas utilizadas pelos homens para dominar o meio. Seguindo essa linha, o americano Carl Sauer (1889 - 1975) levou para os Estados Unidos as reflexões sobre a paisagem que estavam sendo realizadas na Alemanha e que possuíam forte influência das teorias darwinistas (CLAVAL, 2001). Sauer afirmava que o interesse da geografia estava nas marcas deixadas pelo homem na terra, desconsiderando as crenças, costumes e conteúdos simbólicos. A definição do autor sobre o conceito de paisagem cultural era orientado por uma visão que elencava a cultura como agente, a área natural como meio e a paisagem cultural como resultado (SAUER, 2004).

A paisagem passa a ser entendida como artefato, resultado da ação humana pautada na noção de fisionomia: a paisagem consiste em um texto, cuja leitura proporciona o conhecimento dos processos que não podem ser vislumbrados em sua superfície. Trata-se de uma postura "realista" do ponto de vista filosófico, segundo Besse, que o autor identifica não só na geografia, mas na sociologia, história (exceto na história da arte), no planejamento, arquitetura, campos cuja relação com a paisagem é explicitada "por uma intenção de

2 Conforme SCHENK (2008), “Embora o naturalista prussiano defendesse o mérito da experiência sobre a representação, percebia na arte de pintar paisagens e apresentá-las ao observador remoto, um meio de fazê-lo participar desse momento único de comunhão e totalidade; ele recomendava aos pintores que, evitando as estufas ou obras de botânica, trabalhassem nos sítios de onde extraiam suas paisagens, de modo que pudessem entrar em comunicação com a natureza e, graças a isso, obter uma representação que possuísse a emoção dos lugares mesmo" (SCHENK, 2008, p. 9). A respeito da imbricação entre a noção de paisagem e a dimensão estética, Bartalini (2013b) afirma que "...mesmo reconhecendo e defendendo a necessidade e a importância de uma atitude científica, seja analítica ou relacional, os propositores do conceito de fisionomia aplicado à paisagem recorrem à seleção das "variáveis" e à síntese promovida pelo olhar para chegar à visão de conjunto, com o que já se gravita num campo que, se não é o da arte, não é totalmente estranho a ele" (BARTALINI, 2013b, p. 42).

3 Segundo Paul Claval (2001), um dos protagonistas dessa geografia que passa a considerar o homem na constituição da paisagem é Friedrich Ratzel, que introduz o conceito de "antropogeografia". 
conhecimento e de intervenção, ou seja, de projeto, sobre o território" (BESSE, 2006, p. 64).

A outra "porta" proposta por Besse, que concebe a paisagem enquanto objetividade é da paisagem como meio ambiente material e vivo das sociedades humanas. Ela se refere à noção de "ecúmeno" abordada desde o século XVI, segundo a qual se buscava abarcar com o olhar a superfície terrestre que reúne um mundo humano e um mundo natural. O ecúmeno diz respeito a "um mundo vivido, fabricado e habitado por sociedades humanas em constante mudança” (BESSE, 2014, p. 37).

Se, em um primeiro momento, identificava-se o ecúmeno em uma pequena parcela do globo, concebendoos (ecúmeno e globo) enquanto universos separados, essa perspectiva foi sendo transformada a partir do Renascimento. No contexto de descoberta de novos mundos, ocorreu um processo de reconhecimento da presença humana por quase toda a superfície terrestre, o que promoveu a fusão entre a ideia e a representação do globo e do ecúmeno (BESSE, 2014).

As reflexões sobre o ecúmeno antecipam a noção ecológica de paisagem, que no Século XIX passa a trazer novas questões para se pensar cientificamente a relação entre o ser humano e a base terrestre ${ }^{4}$. Enquanto disciplina que volta sua atenção à noção de fluxos de matéria e energia e de ecossistema do qual o ser humano faz parte, a ecologia concebe o processo de transformação da superfície terrestre segundo uma interação mútua: a natureza transforma e é transformada pela humanidade.

Permeado pelas discussões da ecologia, o contexto contemporâneo torna evidente a questão sobre a coincidência entre o ecúmeno e o globo. Nesse sentido, autores do campo da paisagem do século XX (MCHARG, 1992; SPIRN, 1995; HOUGH, 1998), que constroem suas reflexões sobre a paisagem a partir da ecologia, consideraram o ser humano como integrante dos ecossistemas, abandonando a ideia de que a paisagem se coloca como alteridade, como um outro que seria modificado unilateralmente pela ação humana.

No entanto, Besse identifica, ainda hoje, a presença de uma diferença entre o globo e o ecúmeno que

4 Foi o cientista alemão Ernst Haeckel, em 1869 em sua obra “Generelle Morphologie der Organismen", quem primeiro usou este termo para designar o estudo das relações entre os seres vivos e o ambiente. 
se mantém, mesmo que de maneira tênue. A questão se apoia na ideia de que toda ação humana incide sobre uma base pré-existente, um "substrato" a partir do qual é construída a "obra paisagística" (BESSE, 2014, p. 38). Segundo Besse, isso se torna evidente nos eventos chamados de "catástrofes naturais", ocorrências totalmente desvinculadas da presença humana.

Considerar esse substrato como paisagem deixa patente sua dimensão objetiva, sendo que tal noção serviu de base para as ciências como a geomorfologia, a pedologia, a climatologia, a botânica, a ecologia, entre outras (BESSE, 2014).

A paisagem possui uma substancialidade e uma espessura intrínsecas: é um conjunto complexo e articulado de objetos ou, pelo menos, um campo da realidade material, mais amplo e mais profundo que as representações que a acompanham. A paisagem também é o vento, a chuva, a água, o calor, o clima, as rochas, o mundo vivo, tudo o que cerca os seres humanos: resumindo, todo um meio ambiente cujas evoluções, na verdade, são afetadas, mais ou menos diretamente, pela ação, a emoção e o pensamento humanos; mas, afinal de contas, esse meio ambiente - somos também forçados a reconhecer - existe e se desenvolve sem o ser humano, estava aí antes dele e sobreviverá a ele de uma forma ou de outra (BESSE, 2014, p. 39).

As abordagens apresentadas até aqui concebem a paisagem segundo sua dimensão objetiva, isto é, concreta e instrumental, objeto de interesse científico, seja como ambiente produzido unilateralmente pela ação humana, seja como mundo que se desenvolve apesar da presença do ser humano ou que se articula à sua existência. Como indicado anteriormente, tais concepções objetivas não são independentes de uma construção subjetiva, que cria formas de representação, promovendo interpretações sobre o mundo. Nesse sentido, é importante evidenciar que a subjetividade contida na ideia de paisagem não é secundária e expande o sentido estético do fazer artístico, incialmente apresentado no Renascimento e que, contemporaneamente, apresenta outros desafios.

A paisagem seria construção cultural, no sentido subjetivo de um "véu mental que o ser humano coloca entre ele mesmo e o mundo" (BESSE, 2014, p. 13). Segundo Augustin Berque (1994), geógrafo e filósofo francês, uma sociedade é considerada paisagística, especificamente no mundo ocidental, ao apresentar pelo menos um de quatro fatores: o uso de palavras que referenciam a paisagem; a descrição de paisagens pela literatura; a 
representação pictórica de paisagens e a prática concreta de construção da paisagem, isto é, os jardins.

Ao considerar esses quatro fatores, Berque aborda o tema da paisagem segundo o viés da representação. A paisagem seria, nesse sentido, um elemento que promove a mediação entre o mundo transformado pela sociedade e a maneira como ele é visto e interpretado por ela. Nesse sentido, Berque introduz a ideia de médiance:

O meio é uma entidade relacional, construída pelas várias mediações que são estabelecidas entre seus constituintes subjetivos e objetivos. A paisagem é uma delas. Todas essas mediações - o meio, portantosão animadas por um certo sentido, o que faz com que o ambiente evolua. Eu chamo isso médiance (termo forjado a partir da raiz latina de meio). A médiance anima a paisagem ${ }^{5}$.

No livro "A paisagem como cifra de harmonia", os arquitetos argentinos Fernando Aliata e Graciela Silvestri apontam que as transformações produtivas e "a forma de olhar e representar o mundo" (ALIATA; SILVESTRI, 2008, p. 47 ) são questões centrais para se compreender a paisagem. Os autores descrevem as influências clássicas na definição da paisagem ocidental, que sobreviveram até a modernidade e se vincularam à noção de Natureza e sua relação com a humanidade. Identificam uma passagem do jardim construído dentro de limites, que corresponde à Natureza ideal em âmbito civilizado e separada do selvagem, ao jardim estendido para todo o território, momento em que o conceito de sublime, redefinido no século XVIII e XIX, principalmente na Inglaterra, atribui valor estético à natureza desconhecida.

A paisagem entendida como representação está pautada, portanto, na relação entre homem e natureza, visto que as distintas concepções que envolvem o conceito de Natureza delimitam as abordagens acerca da paisagem.

Alinhados às teses de Berque, esses autores afirmam que "para que exista paisagem não basta que exista "natureza"; é necessário um ponto de vista e um espectador; é necessário, também, um relato que dê sentido ao que se vê e experimenta; é consubstancial à paisagem, portanto, à separação entre o homem e o mundo"

$5 \quad$ No original "Le milieu est une entité relationnelle, construite par les médiations diverses qui s'établissent entre ses sonstituants subjectifs autant qu'objectifs. Le paysage est l'une d'entre eles. L'ensemble de ces médiations - le milieu, donc - est animé d'um certain sens, qui fait que le milieu évolue. J'appelle ce sens médiance (terme forgé à partir de la racine latine de milieu). La médiance anime donc le paysage" (BERQUE, 1994, p. 27). 
(ALIATA; SILVESTRI, 2008, p. 12).

A paisagem enquanto construção cultural diz respeito àquilo que é percebido, interpretado, e traduzido por modos de representação. Considerando essa abordagem, para haver paisagem, é necessário um processo de reflexão, que traduz o mundo concreto de acordo com os valores específicos que regem uma sociedade. O mundo como ele é, a experiência por si só, não se define como paisagem. É preciso um processo criativo que cumule de sentido aquilo que se observa. Um processo de criação artística, uma construção cultural, permite a reconfiguração do que há no mundo, transformando-o ao mesmo tempo em objeto de apreciação e conhecimento.

Tal reflexão se relaciona com a ideia de "artealização" apresentada pelo filósofo francês Alain Roger (2007). O autor inicia seu "Breve tratado sobre a paisagem" afirmando que é somente através da arte que a natureza é convertida em objeto estético, em paisagem, seja in situ (nas intervenções concretas no território) ou in visu (sobretudo nas pinturas de paisagem). Existe uma mediação entre indivíduo e mundo promovida pela arte, que é responsável pela transformação de algo em paisagem de fato. É como se a arte articulasse os valores à dimensão concreta do mundo, engendrando a paisagem passível de fruição, isto é, aquela que carrega sentido. Considerando o contexto contemporâneo, essa paisagem estaria vinculada a um repertório cultural hegemônico, mas também à manifestação de novas percepções sobre o espaço banal, que se mantém à margem da cultura dominante e que, por não condizer com a visão dessa cultura dominante, geralmente não recebe significados:

... não sabemos ver nossos complexos industriais, nossas cidades futuristas, o poder paisagístico de uma rodovia. Somos nós que teremos que forjar os esquemas de visão que os converterão em estéticos. Por enquanto, satisfazemo-nos com a crise, mas talvez seja a partir desse deleite crítico que surgirão os modelos do amanhã ${ }^{6}$.

Dennis Cosgrove (2004), geógrafo orientado pelo método histórico dialético, foi um dos intelectuais que trouxeram contribuições para o campo da Geografia Cultural, ampliando a dimensão subjetiva nos debates sobre a geografia, que, até a década de 1930 abordava predominantemente os aspectos objetivos da paisagem. Claval

6 "... no sabemos ver nuestros complejos industriales, nuestras ciudades futuristas, el poder paisagístico de una autopista. Somos nosotros los que tendremos que forjar los esquemas de visión que nos los conviertan en estéticos. Por ahora, nos complacemos com la crisis, pero quizá sea de esta delectación crítica de donde saldrán los modelos de mañana" (ROGER, 2007, p. 122). 
menciona uma crise da geografia ao longo do século XX e identifica Denis Cosgrove como um dos geógrafos que, no final do século, promoveu a renovação da disciplina ao colocar em primeiro plano o estudo das representações que traduzem a relação entre o homem e o mundo. Tal postura é formulada a partir do momento em que se identifica a insuficiência das teorias pautadas nos utensílios e técnicas, em conjunto com a noção de "gênero de vida" 7, que devido a sua abordagem generalista, não davam conta do contexto da sociedade moderna, em que o progresso tecnológico uniformizou as técnicas, não mais capazes de explicar a diversidade e qualidade das distribuições humanas (CLAVAL, 2001, p. 48).

Assim, Cosgrove entende a paisagem como representação construída socialmente; uma maneira de ver o mundo segundo uma ideologia. Partindo dessa ideia, o autor promove a diferenciação entre paisagens dominantes, aquelas relacionadas às visões hegemônicas, e paisagens alternativas, dentre elas, as excluídas, as residuais e as emergentes.

Mais do que uma proposta de categorização da paisagem, as reflexões de Cosgrove afirmam a existência de construções culturais hegemônicas que orientam a relação entre homem e mundo e a identificação de paisagens, mas também reconhece as manifestações que se colocam à margem dessas representações dominantes.

Tais discussões estão vinculadas ao contexto da geografia norte americana, em desenvolvimento no final do século XX, quando autores como Kenneth Olwig propunham resgatar o significado político da paisagem, tendo em vista seu papel de justiça social. A paisagem seria entendida no âmbito da política, uma articulação entre leis e identidade cultural, postura que questiona a concepção da paisagem como cenário ou como representação de uma cultura dominante. Pelo contrário, a paisagem diz respeito aos costumes das populações, considerando uma abordagem que propõe se distanciar de abstrações fabricadas por forças hegemônicas (WYLIE, 2007).

$7 \quad$ A noção de "gênero de vida" foi proposta por Vidal de La Blache (1845 - 1918) para complementar os estudos sobre a cultura através dos instrumentos utilizados e das paisagens modeladas: "para valorizar os bosques, as pastagens ou os campos que os rodeiam e sobre os quais têm direitos, os grupos foram levados a estruturar seu emprego de tempo, a adotar certas maneiras de fazer e a praticálas em tal ou qual momento do ano em função do ritmo das estações. A noção de gênero de vida permite lançar um olhar sintético sobre as técnicas, os utensílios ou as maneiras de habitar das diferentes civilizações" (CLAVAL, 2001, p. 33). 
Até aqui, os autores apresentados expõem a ideia de paisagem que transita entre subjetividade e objetividade: as reflexões de autores como Berque, Roger, Aliata e Silvestri não desconsideram a dimensão concreta que contribui para a existência da paisagem, mas colocam em evidência o processo subjetivo e cultural que faz com que determinados elementos sejam elevados ao status de paisagem. Por outro lado, conforme observa Besse, abordagens no campo da geografia e ecologia priorizam a dimensão objetiva da paisagem, a qual é definida pela interação concreta entre humanidade e superfície terrestre e que, posteriormente, pode ser objeto de representações. Entre objetividade e subjetividade, as abordagens sobre a paisagem não excluem, mas priorizam um desses aspectos.

Entretanto, Besse segue sua reflexão acrescentando a ideia de um processo de dessubjetivação e desobjetivação (BESSE, 2014, p. 49) presente nas discussões sobre a paisagem. Assim, é importante destacar uma terceira concepção acerca do termo, que se encontra, sobretudo, no campo da filosofia, com vínculos na fenomenologia. Tal abordagem indica um modo de compreender a paisagem enquanto experiência estética, que não se restringe a olhares parcelares (BARTALINI, 2013b).

Frente ao esforço para se conhecer e explicar o mundo, a ciência positivista construiu uma linguagem que pretendeu uma compreensão universal, mas que acabou por reduzir e simplificar a complexidade do mundo. É a partir dessa crítica que o filósofo Maurice Merleau-Ponty (1994) defendeu a fenomenologia como filosofia que concebe o mundo segundo relações: o filósofo pensa "o mundo, o outro e a si mesmo" (MERLEAU-PONTY, 1994, p. 19).

O autor elabora um modo de apreender o mundo pautado em processos descritivos dos fenômenos, isto é, daquilo que antecede a reflexão e que não é explicado por uma estrutura causal. Trata-se de uma filosofia que aborda o encontro ingênuo com o mundo, atribuindo-Ihe estatuto filosófico. Com isso, Merleau-Ponty reconhece o valor científico das experiências diretas, no momento em que ainda não passaram por um processo de interpretação e abstração, dando atenção para sua facticidade. Nesse sentido, a fenomenologia trata das essências, mas não enquanto ideia isolada da experiência, mas das essências repostas na existência. 
Em "Fenomenologia da Percepção", Merleau-Ponty busca apresentar as ideias que construíram essa filosofia, retomando reflexões de Edmund Husserl (1859 - 1938) e Martin Heidegger (1889 - 1976) para, então, consolidar o que é a fenomenologia, campo até então mantido em estado de começo, de problema e de promessa (MERLEAU-PONTY, 1994, p.3).

No prefácio da obra, o autor introduz sua reflexão elegendo os seguintes temas fenomenológicos:

Primeiramente, "trata-se de descrever, não de explicar nem de analisar" (MERLEAU-PONTY, 1994, p. 3). Com isso, o autor argumenta que a fenomenologia fala sobre aquilo que não depende dos símbolos construídos pela ciência. Na verdade, diz respeito às experiências que permitiram a elaboração desses símbolos, sem as quais, eles não fariam sentido nenhum. Invertendo o modo de conceber o mundo consolidado pela ciência moderna, Merleau-Ponty se recusa a reduzir o ser humano e sua experiência no mundo como simples objeto da biologia, da psicologia, da sociologia, etc. Assim, considera que as experiências não são originadas de determinados antecedentes, isto é, ambiente físico e social; de fato, é a própria experiência que

...caminha em direção a eles e os sustenta, pois sou eu quem faz ser para mim (...) essa tradição que escolho retomar, ou este horizonte cuja distância em relação a mim desmoronaria, visto que ela não lhe pertence como uma propriedade, se eu não estivesse lá para percorrê-la com o olhar (MERLEAU-PONTY, 1994, p. $3-4)$.

O autor ainda esclarece que isso não consiste em um "retorno idealista à consciência" (MERLEAU-PONTY, 1994, p. 4), criticando a noção de Kant e Descartes sobre o tema, segundo os quais, sem a consciência, não é possível apreender nada como existente. O que Merleau-Ponty defende é que existe um mundo independente de qualquer análise e a percepção dispensa a elaboração de sínteses.

O segundo tema é a redução fenomenológica, que Merleau-Ponty discorre a partir de uma crítica ao idealismo transcendental de Husserl, segundo o qual ser consciência significa fazer parte de um todo, negando a existência de um outro. Nesse sentido, o mundo se torna transparente e perde sua opacidade; é definido por verdades universais. Para Merleau-Ponty, somos "relação ao mundo" e para constatar esse "movimento", é preciso perder a familiaridade com o mundo. 
A reflexão não se retira do mundo em direção à unidade da consciência enquanto fundamento do mundo; ela toma distância para ver brotar as transcendências, ela distende os fios intencionais que nos ligam ao mundo para fazê-los aparecer, ela só é consciência do mundo porque o revela como estranho e paradoxal (MERLEAU-PONTY, 1994, p. 10).

A redução consiste nesse movimento de distanciamento que permite a identificação de relações. Ela nunca é completa, justamente por não haver espíritos absolutos, mas consciências definidas pelo estar no mundo.

O terceiro tema é a noção de essência. Segundo o autor, "buscar a essência do mundo não é buscar aquilo que ele é em ideia (...), é buscar aquilo que de fato ele é para nós antes de qualquer tematização" (MERLEAUPONTY, 1994, p. 13). A essência seria o meio da filosofia através do qual seria possível conhecer nosso engajamento no mundo.

Por fim, a intencionalidade é mencionada como quarto tema e se trata "de reconhecer a própria consciência como projeto do mundo, destinada a um mundo que ela não abarca nem possui, mas em direção ao qual ela não cessa de se dirigir" (MERLEAU-PONTY, 1994, p.15). Nesse sentido, Merleau-Ponty observa como os acontecimentos, no momento em que ocorrem, parecem ser regidos pelo acaso, mas que devem ser compreendidos segundo a ideologia, a política, a religião, a economia, etc., isto é, possuem um significado, mesmo os gestos humanos distraídos e habituais. "Porque estamos no mundo, estamos condenados ao sentido, e não podemos fazer nada nem dizer nada que não adquira um nome na história” (MERLEAU-PONTY, 1994, p. 18)

Contemporâneo a Merleau-Ponty, o neuropsiquiatra alemão Erwin Straus (2000) ${ }^{8}$ pensaria a paisagem segundo a fenomenologia em seu texto "Du sens des sens" no qual apresenta uma distinção entre o mundo animal da sensação e o mundo humano da percepção, explicitada por meio de reflexões acerca do espaço, da música e da família.

Para Straus, em relação ao espaço, a paisagem estaria no domínio do sentir e seria o encontro anterior a qualquer esforço de reflexão, anterior à percepção. Partindo dessa ideia central, o autor define a paisagem (1994).

Conforme Besse (2014), este trabalho de Erwin Straus exerce influência em Merleau-Ponty e sua “Fenomenologia da Percepção" 
como o espaço da sucessão de horizontes, espaços adjacentes desconhecidos, onde é possível se perder. Difere do espaço geográfico, pertencente ao domínio da percepção, da ação reflexiva e da abstração. Esse espaço é destituído de horizontes, transparente, determinado por pontos fixos, cartesianos (STRAUS, 2000).

Conforme observa Besse, essa abordagem de Straus que separa paisagem e geografia causa certo estranhamento, visto que a geografia de início do século XX dedicava atenção ao encontro direto com a paisagem para a construção do conhecimento. As concepções puramente abstratas já estavam sendo questionadas pela geografia do tempo de Straus e a fenomenologia já vinha contribuindo com a renovação da teoria e prática da disciplina.

A relevância da reflexão de Straus para a investigação sobre a paisagem está menos na definição elaborada pelo autor sobre o que seria a geografia e mais na atenção direcionada ao aspecto sensível da paisagem, referente a um contato direto com uma realidade, desvinculado de racionalizações e representações.

Para Straus, nem mesmo as pinturas de paisagem são uma forma de percepção e representação; elas "tornam visível o invisível” (STRAUS, 2000 apud BESSE, 2014, p. 53). Segundo Jean-Marc Besse, ao mencionar essa reflexão de Straus, a filosofia e o poema seriam formas de prolongar a paisagem.

Identifica-se uma aproximação com a noção de artealização de Roger; no entanto, a paisagem determinada por esse processo não seria representação:

De forma geral, somente a arte, como o poema, e talvez a mística podem dizer essa experiência da paisagem ou, mais precisamente, dar a ver e a ouvir essa paisagem como experiência fundamental, originária, da conivência com o mundo. A arte não porque representaria a paisagem, mas porque mostra a paisagem, porque a faz chegar como tal à presença e, mais geralmente, porque faz aparecer o mundo enquanto mundo (BESSE, 2014, p. 53).

No campo da geografia, a fenomenologia ancora o pensamento de Eric Dardel (2011). Desviando-se da produção teórica majoritária da disciplina em meados do século XX, o autor define a geografia como experiência anterior aos conhecimentos objetivos e neutros formulados pela ciência, dialogando com o discurso de MerleauPonty. Ao falar sobre a geografia, o autor a interpreta como algo que ultrapassa os limites da formulação de um 
campo de conhecimento. Dardel defende a existência de uma "geografia em ato" (DARDEL, 2011, p. 1), o que o faz redigir em seu livro "O homem e a terra" uma história da geografia que antecede o século XIX, momento em que se constrói formalmente a disciplina.

Ao descartar o objetivo de organizar cronologicamente uma sequência de elaborações teóricas que definiram a geografia ao longo do tempo, Dardel identifica "concepções de mundo", isto é, cada "consciência geográfica, através das diferentes intenções sob as quais aparece ao homem a fisionomia da terra" (DARDEL, 2011, p. 47). Nesse sentido, o autor explora mentalidades que corroboram a separação entre ser humano e mundo e o estabelecimento das bases para se falar de uma geografia enquanto objeto de estudo e não como realidade da qual o ser humano participa. Assim, enquanto uma "geografia mítica" concebe a Terra como um poder, uma origem a partir da qual se constituem e sobrevivem em conjunto todos os seres, a "geografia heroica" cria condições para a separação entre Terra e homem, este adquirindo uma postura de explorador motivado pelo desejo de domínio. Isso abre caminho para uma "geografia científica", que promove definitivamente o recuo com relação ao objeto, caracterizando-se como uma "geografia de laboratório" (DARDEL, 2011, p. 87).

No que diz respeito à postura de Dardel, o autor defende que a geografia antecede a ciência exata e que o espaço geográfico é plural, diferente do espaço geométrico homogêneo. O espaço geográfico é, antes de tudo, compreendido a partir da referência humana, menos como um instrumento do que uma condição a partir da qual se manifesta a liberdade do ser humano de acordo com sua "situação", seja pela busca da redução de distâncias, ou pela determinação de uma direção. Nesse sentido, Dardel define o "espaço telúrico", que expressa a profundidade, a espessura e a plasticidade do espaço geográfico; o "espaço aquático", que é movimento e temporaliza o mundo; o "espaço aéreo", invisível, porém sempre presente, pela relação entre sombra e luz, frio e calor, odor e que abriga a realização do desejo humano de voar e de abarcar visualmente o mundo segundo uma nova perspectiva; e o "espaço construído", que se refere à obra humana, principalmente ao habitat onde acontece a vida cotidiana, incluindo os caminhos que dão sentido ao espaço geográfico.

Segundo Dardel, a paisagem é a conjugação desses espaços de acordo com a presença humana e uma "tonalidade afetiva dominante" (DARDEL, 2011, p. 31). Para o autor, "muito mais que uma justaposição de 
detalhes pitorescos, a paisagem é um conjunto, uma convergência, um momento vivido, uma ligação interna, uma "impressão", que une todos os elementos" (DARDEL, 2011, p. 30). Trata-se de um evento, no qual se dá o encontro direto do homem com as coisas. "A paisagem não é, em sua essência, feita para se olhar, mas a inserção do homem no mundo, lugar de combate pela vida, manifestação de seu ser com os outros, base de seu ser social" (DARDEL, 2011, p. 32).

Como alternativa à descrição científica que não é capaz de abarcar a realidade geográfica em todos os seus aspectos, Dardel identifica na linguagem do poeta uma expressão que "dá ao termo concreto seu amparo e sua medida" (DARDEL, 2011, p. 3).

Dardel e Straus têm definições contraditórias do que venha a ser a geografia, mas, para além disso, ambos apresentam um entendimento da paisagem como experiência, como afetação do corpo por eventos externos e realização desse momento independente de racionalizações ou qualquer tipo de construção subjetiva. Ambos os autores participam do contexto em que a fenomenologia se destaca enquanto modo de conhecer o mundo e que estabelece que esse mundo é anterior a qualquer representação. Não se refere a um processo subjetivo de interpretação, nem a uma abstração, mas consiste em uma apreensão sem mediações.

Observando as principais questões apresentadas, é possível verificar que a ideia de paisagem transita entre objetividade e subjetividade. Sua definição depende de valores que traduzem o mundo criando formas de representação, o que é evidente nas pinturas de paisagem, nas cartografias; depende também da dimensão concreta que afeta e é afetada pelo ser humano; relaciona-se ao que se encontra entre essas duas acepções: a paisagem é uma experiência. 


\section{Novas paisagens: à margem}

O filósofo Henri Lefebvre (2002) tem como principal abordagem a problemática urbana, sendo que encontra no cotidiano a potência para a subversão dos saberes dominantes. Nesse sentido, tece forte crítica à teoria e prática da Arquitetura e Urbanismo e seu discurso é acompanhado por outros autores da década de 1960 (LYNCH, 2011; CULLEN, 2002; JACOBS, 2013).

Em seu livro "A Revolução Urbana", Lefebvre elabora uma crítica à produção de conhecimento pautada na sucessão de etapas da civilização (o rural, o industrial, o urbano), que não visualiza a transição, desigualdade de desenvolvimento e sobreposição desses momentos. Partindo dessa ideia, o autor define a noção de "campo cego", no qual "o cegante é a fonte luminosa (conhecimento e/ou ideologia) que projeta o facho de luz, que ilumina alhures. O cegado é o olhar ofuscado; é também a zona deixada na sombra. De um lado uma via se abre à exploração; de outro, há uma barreira a romper, uma sanção a transgredir" (LEFEBVRE, 2002, p. 40).

Pensar as discussões de paisagem segundo a perspectiva que denuncia a existência de um "campo cego" supõe voltar os olhares para outros espaços e outras percepções do urbano, que se mantém nas bordas do processo de construção de representações segundo uma cultura dominante. Nesse sentido, essa paisagem que habita as margens geralmente não faz parte dos processos de planejamento da cidade e são esquecidas pelas disciplinas que tem a cidade como tema nevrálgico, apesar de consistirem em parte constituinte do cotidiano urbano.

Observando o contexto das cidades contemporâneas, a paisagem não é mais definida pela oposição entre urbano e natural, mas envolve também o urbano. Seja pelas novas formas da cidade, seja pela sua articulação com o que se entende por natureza, a paisagem pode ser percebida segundo novos valores.

Há um rebatimento dos valores que condicionam a sociedade contemporânea na concretização do 
mundo. A razão neoliberal (LAVAL; DARDOT, 2016) ${ }^{9}$, os processos de financeirização, a terra transformada em ativo financeiro (ROLNIK, 2016) ${ }^{10}$, a especulação imobiliária que cria vazios urbanos e abandona pedaços de cidade (CALDEIRA, 2010) ${ }^{11}$ contribuem para novos modos de perceber o mundo. Os espaços deixados à margem e ao mesmo tempo resultantes dessas dinâmicas, geralmente se mostram incompatíveis com as concepções dominantes sobre a paisagem, que dizem respeito principalmente a projetos realizados e intenções de ordenamento e desconsideram o complexo histórico de formulação da noção. Trata-se de percepções orientadas pelo desejo de tornar o mundo habitado funcional, organizado, esteticamente agradável e economicamente relevante.

Frente à obsolescência de determinados valores que definiram a paisagem em outras épocas, Alain Roger anuncia a necessidade de criar novos modos de olhar o mundo, que permitam a apreciação estética e o reconhecimento enquanto paisagem dos espaços contemporâneos.

De forma paralela, acompanhando a transformação da realidade urbana, Silvestri e Aliata buscam compreender como se coloca a ideia de paisagem frente às novas formas de cidade e cultura. Segundo os autores, a identificação da paisagem, quando orientada pela ideia de natureza, é evidenciada pela existência do urbano.

9 No livro "A nova razão do mundo", Christian Laval e Pierre Dardot buscam compreender como os desdobramentos do capitalismo em uma racionalidade neoliberal constroem ideologias e disciplinas que orientam o indivíduo para o governo de si, partindo de um estudo do contexto europeu. No período de desgaste do governo do bem estar social, a ideologia neoliberal é construída por subjetividades que atribuem a todas as esferas da vida a lógica empresarial, alicerçada no princípio de competitividade. Nesse contexto, os autores argumentam que o que ocorre não é uma retirada do Estado do poder, que concederia ao mercado o papel de organizador da sociedade, mas, sim a reestruturação desse Estado, ele próprio convertido em empresa. Mesmo que Laval e Dardot se refiram a um processo histórico especificamente europeu, a razão neoliberal constitui a atual conjuntura global, influenciando as formas de governo locais. Nesse sentido, articulando essas questões à disciplina de Arquitetura e Urbanismo, encontramos suporte para compreender os modos de gestão da cidade e a materialização dessas lógicas no espaço urbano e nas relações entre sociedade e paisagem.

10 O livro de Raquel Rolnik "Guerra dos lugares" pode ser lido como uma abordagem dos desdobramentos da ideologia neoliberal no campo da Arquitetura e Urbanismo, na medida em que o processo de financeirização da economia promove um modo de construção do espaço urbano pautado pela lógica da rentabilidade.

11 O trabalho de Teresa Caldeira "Cidade de muros" explora a transformação da segregação socioespacial na cidade de São Paulo, não mais baseada em uma periferia pobre e um centro rico. A multiplicação de condomínios fechados explicita um modo contemporâneo de se construir a cidade que cria espaços vazios indeterminados. 
... a sensibilidade diante da natureza é inseparável do renascimento da vida urbana, do avanço das técnicas, da vontade expressa de domínio sobre as superfícies terrestres e da centralidade da razão, aspectos que aparentemente opõem homem e natureza. Na medida em que se desdobram as possibilidades de progresso, acentua-se a nostalgia por uma suposta unidade original. É que somente se a natureza é dominada e deixa, portanto, de ameaçar a existência humana, pode ser construída como uma fonte de consolo e harmonia (ALIATA; SILVESTRI, 2008, p.18).

Mas em conjunto com a visão da cidade orientada segundo a nostalgia por uma natureza primordial, os autores mostram que uma face contrastante a esse desejo é exposta na construção das cidades no decorrer do desenvolvimento tecnológico. Trata-se de cidades cujas paisagens não se enquadram nos valores construídos até então. Conforme Aliata e Silvestri, "pode-se hoje observar como paisagem um conjunto de objetos do habitat que antes careciam de significação" (ALIATA; SILVESTRI, 2008, p. 194). Aqui os autores se referem ao strip de Las Vegas, que consiste nas grandes avenidas onde predomina a linguagem dos cassinos e hotéis, das imagens apreendidas em alta velocidade e que "longe de testemunhar uma harmonia perdida entre o homem e o mundo, testemunham, ao contrário, a definitiva excisão” (ALIATA; SILVESTRI, 2008, p. 194).

Tal concepção é construída a partir do século XX, no campo disciplinar da arquitetura, que apresenta a valorização da paisagem natural tal-qual-é (ALIATA; SILVESTRI, 2008, p. 197), promovendo o contraste entre a construção e a natureza circundante. Essa lógica passa a se entrelaçar com o mundo pop que "se opõe radicalmente aos controles da forma" (ALIATA; SILVESTRI, 2008, p. 201). Daí a definição como paisagem de elementos que até então não apresentavam valor estético frente ao distanciamento em relação ao repertório artístico consolidado ao longo dos séculos anteriores.

Nesse sentido, é justamente no banal, naquele lugar aparentemente destituído de significados, que a ideia de paisagem vai encontrar sua potência na cidade contemporânea. Os espaços banais da cidade são os horizontes a serem descobertos na realidade atual, na qual uma ciência positivista já permitiu, supostamente, o conhecimento de todos os cantos do mundo. A descoberta e conhecimento das paisagens banais depende da frequentação de lugares indeterminados (CARERI, 2013). A apreensão de tais lugares enquanto paisagens se coloca como desafio frente à correlata desconstrução da antiga ordem econômica e a entrada de uma nova ordem contemporânea de matriz financeira e globalizada. 
Em uma organização de textos promovida por Javier Maderuelo (2008), que recebe o título de "Paisaje y Territorio", um dos autores, o geógrafo Joan Nogué, defende que o invisível, o intangível e o efêmero devem ser considerados como categorias para a intervenção no território. A importância que o autor concede a essas categorias vem do reconhecimento de um contexto no qual a identificação de atores e a organização de processos de intervenção se mostram complexos, tendo em vista seu caráter capilarizado, difuso: "vivemos em uma época dominada cada vez mais pela invisibilidade (...). A distribuição do poder é, hoje, muito volátil; a determinação das causas e das responsabilidades, mais complexa; os interlocutores são instáveis, as presenças, virtuais" 12.

Para o autor, a invisibilidade corresponde aos "espaços em branco" denunciados pelas tecnologias atuais, que mostram nos mapas a existência de limites pouco definidos, de uma "cidade oculta" que reúne espaços que não são desejáveis e por isso não são visíveis. Não são visíveis porque não são legíveis e se torna difícil descreve-los frente a uma aparente semelhança entre todos eles. Assim, essa lógica impede o reconhecimento das paisagens representadas, culturalmente determinadas, nas paisagens cotidianas. Esses espaços em branco podem ser considerados iguais enquanto categoria, mas cada um é particular em sua ocorrência e aparência.

Joan Nogué propõe que a atenção de quem lida com o projeto e o planejamento do território não se limite às presenças e que se direcione também às ausências. Nesse sentido, pode-se retomar Dardel, que já dizia que "a paisagem pressupõe uma presença do homem, mesmo lá onde toma a forma de ausência" (DARDEL, 2011, p. 32).

Outra categoria apresentada por Nogué é a intangibilidade, que se define pelo que não se enquadra em discursos técnicos ou jurídicos, pelo que não é quantificável e, portanto, são identificados pelos setores econômicos como obstáculos ao progresso. A paisagem da intangibilidade é aquela que não se resume à visão, mas depende de outros estímulos sensíveis: o tato, o olfato, a audição.

Essa categoria aproxima-se da concepção fenomenológica da paisagem, ao considerar fatores que

12 No original "Vivimos en una época dominada cada vez más por la invisibilidade (...). La distribuición del poder es, hoy, muy volátil; la determinación de las causas y de las responsabilidades, más compleja; los interlocutores son inestables, las presencias, virtuales" (NOGUÉ, 2008, p. 183). 
complementam o campo daquilo que é visto, abstraído e representado (medido, quantificado). Encontra-se, sobretudo, no domínio do sensível, da experiência de encontro direto com o mundo.

Enfim, a efemeridade consiste no tempo da vida cotidiana e está presente nas paisagens sem limites geográficos precisos, que não estão submetidas a um controle e são características do contexto contemporâneo.

No campo da Arquitetura e Urbanismo, as categorias da invisibilidade, intangibilidade e efemeridade, identificadas na cidade contemporânea, podem ser relacionados ao discurso do arquiteto italiano Francesco Careri (2013), autor que dedica o livro "Walkscapes: o caminhar como prática estética" ao caminhar, à cidade nômade. Careri foi fundador do grupo Stalker ${ }^{13}$, que iniciou em 1995 a prática denominada pelo autor como "transurbância", isto é, o percurso realizado pelos espaços de fronteira da cidade de Roma. No prefácio da edição brasileira de 2013, Paola Berenstein Jacques usa vários termos para precisar tais espaços: espaços entre, provisórios, inacabados, brechas, sombras e sobras. Segundo a arquiteta é nesses espaços nômades que se torna possível o encontro com a diversidade, com o Outro, encontro dissensual e conflituoso, necessário para a construção da esfera pública e de uma cidade menos espetacularizada (JACQUES, 2013).

Em "Walkscapes", Careri discorre sobre os significados do caminhar em determinados períodos da história da humanidade, destacando inicialmente os percursos realizados no paleolítico e a posterior construção dos menires no neolítico, que são objetos que marcam concretamente os percursos realizados pelo território e que se colocam como "a primeira ação humana de transformação física da paisagem" (CARERI, 2013, p. 52). O desenvolvimento do texto então salta para o fazer artístico do século XX, que dá ênfase para o caminhar enquanto transformação física e simbólica da paisagem. Nesse sentido, segundo Gilles A. Tiberghien, o caminhar seria uma prática esquecida pelos arquitetos urbanistas e "reabilitada pelos poetas, pelos filósofos e pelos artistas capazes precisamente de ver aquilo que não há, para fazer brotar daí algo" (TIBERGHIEN, 2013, p. 18).

Segundo essa perspectiva, Careri argumenta a necessidade de percorrer os espaços vazios da cidade, os

13 O nome do grupo baseou-se no filme "Stalker" de Andrei Tarkovski (1979), o qual retrata a "zona" como um lugar indeterminado nas bordas da cidade e que começa a "se mexer" na presença de pessoas (CARERI apud JACQUES, 2013). 
lugares escondidos, que permeiam todo o território e que abrigam a cidade nômade dentro da cidade sedentária (CARERI, 2013). Resgatar, através da arquitetura e urbanismo, os significados do caminhar enquanto prática estética seria o caminho para tornar visíveis certas paisagens da cidade, que são a contraparte de um espaço organizado e funcionalizado.

Voltando a atenção para os espaços vazios da cidade, Careri descreve a cidade contemporânea segundo a imagem de um arquipélago: "o suprimido, o resíduo, a ausência de controle produziram um sistema de espaços vazios (o mar do arquipélago) que podem ser percorridos indo à deriva" (CARERI, 2013, p. 30). Assim, Careri interpreta a errância como arquitetura da paisagem e como modo de "habitar o mundo", que ultrapassa a simples satisfação de necessidades de sobrevivência e transforma o espaço antrópico, não só fisicamente, mas simbolicamente (CARERI, 2013).

Em livro mais recente, "Caminhar e parar" (2017), Careri aprofunda sua reflexão sobre os vazios urbanos e suas características próprias, que prescindem de uma ação que objetiva dar-lhes qualidades e significados. Nesse sentido, é possível apreender no discurso do autor a ideia de campo cego de Lefebvre, visto que o arquiteto italiano visa abarcar aquilo que não se enquadra nas visões objetivas que planejam e definem o território.

Observando o contexto de Roma, Careri retoma a ideia do arquipélago e descreve o território a partir da existência de ilhas, que o autor chama de clusters (CARERI, 2017, p. 18), fragmentos de cidade plena, construída. Essas ilhas estão distribuídas por um sistema de vazios, "uma nova wilderness" (CARERI, 2017, p. 23), que se encontra em constante devir. Há uma multiplicidade de forças locais e globais que agem sobre esse conjunto caracterizando um processo complexo e espontâneo, independente das teorias dos arquitetos e urbanistas.

Não se trata apenas de uma somatória de espaços residuais à espera de serem preenchidos por coisas, mas, se tanto, por significados. Não se trata de uma não cidade a ser transformada em cidade, uma área desprovida de sentido à qual atribuí-lo graças a um qualquer tipo de colonização, mas de uma cidade paralela com dinâmicas e estruturas próprias, com uma identidade formal própria, inquieta e palpitante de pluralidades, dotada de redes de relações, de habitantes, de lugares, de monumentos, e que deve ser compreendida antes de ser estruturada ou, no melhor dos casos, requalificada (CARERI, 2017, p. 23 ). 
Outro autor vinculado às práticas de intervenção no território e que mostra interesse pela definição dessas novas paisagens contemporâneas é o paisagista e botânico francês Gilles Clément (2004). Ele elabora uma reflexão acerca dos espaços de margem, aos quais dedica o "Manifesto da Terceira Paisagem" (Manifeste du tiers paysage). Nele, o autor articula conceitos ecológicos com a caracterização dos espaços que compõem a superfície do planeta de acordo com a intervenção humana. Assim, identifica como pertencentes à Terceira Paisagem, os resíduos, ou seja, lugares que restam entre as intervenções humanas e que são refúgios da diversidade, considerando o sentido ecológico do termo. Podem apresentar dimensões modestas e se organizarem de maneira dispersa e podem abranger amplos territórios formando conjuntos unitários.

Se deixarmos de olhar a paisagem como se fosse o objeto de uma indústria poderemos descobrir de repente - trata-se de um esquecimento do cartógrafo, de uma negligência do político? - uma grande quantidade de espaços indecisos, desprovidos de função, o que faz com que seja dificil dar-lhes um nome. Este conjunto não pertence nem ao domínio da sombra nem da luz. Está situado em suas margens: nas bordas dos bosques, ao longo das estradas e dos rios, nos cantos mais esquecidos da cultura, alí onde as máquinas não podem chegar ${ }^{14}$.

Esses espaços são, segundo o autor, resultado dos interesses econômicos, que elegem espaços rentáveis para serem incluídos em seu jogo e abandonam o que não contribui com seus objetivos. Com isso, a Terceira Paisagem se torna o refúgio da diversidade, na medida em que abriga espécies pioneiras que apresentam ciclos rápidos de sucessão, as quais não são compatíveis com os lugares onde se encontram espécies em seu estado de clímax. As margens, enquanto lugar do inconstante, diferenciam-se do "miolo", espaço relativamente estável e consolidado.

Nesse sentido, Gilles Clément afirma que o abandono institucional é essencial para a existência da Terceira Paisagem, a qual é incompatível com a noção de patrimônio. Isso porque seu desenvolvimento se refere menos a um sistema econômico do que a um sistema biológico. Tal diferenciação atribui um sentido importante para a

14 No original "Si l'on cesse de regarder le paysage comme l'objet d'une industrie on découvre subitement - est - ce un oubli du cartographe, une négligence du politique? - une quantité d'espaces indécis, dépourvus de fonction sur lesquels il est difficile de porter un nom. Cet ensemble n'appartient ni au territoire de l'ombre ni à celui de la lumière. Il se situe aux marges. En lisière des bois, le long des routes et des rivières, dans les recoins oubliés de la culture, là où les machines ne passent pas" (CLÉMENT, 2004, p. 4). 
noção de abandono, visto que não se trata de um abandono pela população de modo geral, frente a uma suposta ausência de significados ou valores que esses espaços possam ter. Trata-se, especificamente, de um abandono pelo mercado. Essa questão se aproxima da abordagem de Careri, segundo o qual, esses espaços não são considerados necessários para os processos econômicos, mas fazem parte do funcionamento de outras lógicas, seja no sentido ecológico, que é o foco da reflexão de Clément, seja no sentido sociocultural da apropriação.

No contexto contemporâneo, a arquitetura da paisagem se depara com uma realidade efêmera, com a criação de paisagens divergentes de um repertório consolidado, as quais são frequentemente ocultas por diversas dinâmicas de funcionamento da sociedade, sobretudo, econômicas. Partindo dessa tentativa de investigar o que venha a ser o objeto de intervenção em Arquitetura da Paisagem, resta pesquisar operações e ferramentas que sejam condizentes com a complexidade desse objeto. 


\section{Cartografia}

\section{Ciência e arte: do contato à ruptura}

Cartografia e Paisagem são temas que se articulam ao longo da história, engendrando questões relativas à representação, à transformação e à experimentação do mundo pelo homem.

A construção inicial da noção de paisagem no Ocidente teve relação com os modos de representar o mundo e de inventariar o território, desenvolvidos ao longo do século XVI (MADERUELO, 2008). Num momento em que ciência e arte estavam articuladas, o mapa recebia das pinturas de paisagem o complemento necessário para representar o território habitado pelo homem. Conforme observa Javier Maderuelo, enquanto os pintores elaboravam uma representação em plano vertical (através de uma janela hipotética) apoiando-se na perspectiva como ferramenta, os cartógrafos efetuavam uma projeção horizontal partindo de uma visão superior imaginária, possibilitada pela Trama de Ptolomeu ${ }^{15}$. Essa prática se enquadrava nos valores vigentes desde o Renascimento, que delineavam o desejo de conhecer os fenômenos físicos que caracterizam o mundo e distanciavam progressivamente a nova cartografia do conteúdo simbólico dos mapas medievais (MADERUELO, 2008).

Nesse contexto, a paisagem estava vinculada à corografia, que buscava a descrição dos fenômenos em seus detalhes; por sua vez, a cartografia ocupava-se das grandes massas (BESSE, 2006). Segundo Denis Cosgrove (1999), no momento nascente do período moderno, cosmografia, geografia e corografia eram as práticas que visavam à descrição e representação do mundo: a cosmografia diz respeito à concepção total do cosmos, diante do qual o indivíduo ocupa posição central; a geografia trata das divisões da superfície terrestre e supõe um observador acima da Terra; a corografia trata do que é imediatamente visível em um local e conta com um observador cujo ponto de vista é relativo e subjetivo.

15 Essa ferramenta de representação do território foi elaborada pelo geógrafo helenista no século II e redescoberta no século XV. A Trama de Pitolomeu possibilitou o desenvolvimento empírico do sistema de meridianos e paralelos (MADERUELO, 2008). 
A atitude contemplativa diante da paisagem condiz com a relação entre homem e superfície terrestre característica dos primórdios da era moderna. Conforme Besse, o mapa medieval "insere a Terra, e o indivíduo que observa a sua imagem, no discurso, a um só tempo físico e teológico, da Criação do mundo" (BESSE, 2006, p. 26). Retomando Dardel, a concepção de mundo vigente nesse período estava relacionada à geografia mítica que concebe a Terra como origem e estabelece ligações permanentes com o homem, desde seu nascimento até sua morte. Ao longo do século XVII, tal mentalidade é progressivamente transformada, dando lugar a uma separação entre homem e mundo. A Terra não é mais concebida como o resultado de uma Gênese, mas sim como a condição para o desenvolvimento dos sentidos do Tempo e da História; o espaço não é mais inscrição do tempo, mas sim Aberto. Diante disso, o ser humano se coloca como observador (mas ao mesmo tempo, participante, tendo em vista a escala abarcada pela corografia) diante da paisagem espetáculo, cuja forma de representação consiste em uma totalidade abarcada pelo olhar superior (BESSE, 2006).

A paisagem que traduz essa concepção de mundo estaria presente nas pinturas de Peter Brueghel, conforme aponta Besse, nas quais são apresentadas vistas panorâmicas em conjunto com seus observadores, que podem ser camponeses ou viajantes que se encontram em um ponto elevado e, por estarem desocupados de obrigações, são capazes de apreender a paisagem enquanto tal.

A cartografia que se dedicava a descrever esse mundo se apoiava em princípios geométricos, os quais, segundo os valores vigentes na época, possibilitariam o acesso à verdade, seguindo a tradição platônica, que considerava os conceitos abstratos verdadeiros, em contraposição à incerteza e mutação dos fenômenos. "O pintor e o cartógrafo, ambos observadores de espaços e de fenômenos do mundo terrestre, desenvolvem uma arte da leitura visual dos signos que constituem a qualidade própria de uma paisagem” (BESSE, 2006, p. 19).

Nesse primeiro momento de contato entre arte e ciência, paisagem e cartografia, a representação do mundo é feita segundo um esforço de imaginação, um processo criativo que supõe um ponto de vista superior virtual do território, impraticável com as tecnologias existentes na época. Como produto exemplar desse momento, autores citam o Teatrum Orbis Terrarum de Abraham Ortelius (1570), que reúne a visão imaginária superior da terra aos detalhes observados durante a realização de viagens (COSGROVE, 1999; BESSE, 2006). 
Michel de Certeau (2007) identifica no período de nascimento do discurso científico moderno (século XV ao XVII) um processo que desvincula o mapa dos itinerários, transformando o mapa em representação totalizadora, que torna invisível a operação, que até então, era parte constitutiva das representações cartográficas.

Transformado pela geometria euclidiana e mais tarde descritiva, constituído em conjunto formal de lugares abstratos, é um "teatro" (este era antigamente o nome do atlas) onde o mesmo sistema de projeção justapõe no entanto dois elementos bem diversos: os dados fornecidos por uma tradição (a Geografia de Ptolomeu, por exemplo) e aqueles que provinham de navegadores (os portulanos, por exemplo). (...) O palco, cena totalizante onde elementos de origem vária são reunidos para formarem o quadro de um "estado" do saber geográfico, afasta para a sua frente ou para trás, como nos bastidores, as operações de que é efeito ou possibilidade. O mapa fica só. As descrições de percursos desaparecem” (CERTEAU, 2007, p. $206-207)$

A concretização da visão superior do mundo foi possível apenas no final do século XVIII com a invenção de tecnologias que permitiram o sobrevoo do território. Em um primeiro momento, os voos de balão ${ }^{16}$ e, na sequência, de avião, mesmo sem uma nova técnica de registro do que se observava, possibilitaram um ponto de vista do território que até então era apenas imaginado. Tal ponto de vista, segundo Besse, prolonga a tradição filosófica da época helênica, em que Platão e Aristóteles reconheciam a contemplação como fundamental para o filósofo na busca pela verdade. O autor assinala que, mais do que uma inovação técnica, o olhar aéreo dá acesso a uma nova dimensão do real e "...não se contenta em assinalar a existência das aparências passageiras do mundo, demonstra a consistência dessas aparências e (...) sua estrutura e substancialidade (BESSE, 2014, p. 67).

Segundo Besse, o olhar e a fotografia aérea ${ }^{17}$ permitem uma apreensão da paisagem em sua dimensão ontológica. Isso significa que não se trata de uma abordagem hiperobjetivista ou hipersubjetivista que exclui a paisagem de fato e se refere às máscaras que a recobrem ou as concepções que a representam. A visão de sobrevoo abarca a paisagem em si, se esta for entendida como uma concretude cuja existência se dá pela interação entre as sociedades humanas e a Terra.

Conforme aponta Besse, essa nova perspectiva sobre a Terra é encarada por John Brinckerhoff Jackson

16 O primeiro voo de balão foi realizado em 1783 pelos irmãos Montgolfier: os franceses Joseph-Michel e Jacques-Étienne.

17 O fotógrafo francês Félix Nadar registrou uma patente para um sistema de fotografia aeroestática em 1858 (BESSE, 2014). 
como uma possibilidade instigante de formular novos questionamentos sobre a relação do ser humano com a superfície terrestre e sobre as relações entre seres humanos. O historiador americano não reconhece no olhar aéreo uma atitude dominadora, mas, sim, investigativa.

Trata-se de uma concepção de paisagem que prioriza a dimensão visual que esteve presente desde as origens da geografia. Considerando a aplicação da fotografia aérea na geografia e tendo em vista a potência de conhecimento fornecida por essas imagens, tornou-se possível um aperfeiçoamento ou até mesmo a substituição do mapa para a observação da hidrografia, topografia, cobertura vegetal e formas de assentamento humano. Para esses objetivos, a nova técnica de observação e registro da superfície terrestre se mostrou mais eficiente do que a caminhada que, inserida nos detalhes do território, deformaria a visão de uma totalidade. A apreensão simultânea dos diversos aspectos que caracterizam o território, bem como a possível constatação da sobreposição de processos humanos, "restitui transparência às camadas de história humana que marcaram a paisagem" (BESSE, 2014, p. 93).

Segundo o autor, "o avião é uma espécie de atlas em ação. Seu movimento acima da paisagem permite medir com o olhar as formas territoriais e os limites dessas formas, as descontinuidades espaciais, os usos diferenciados do espaço que se justapõem no mundo" (BESSE, 2014, p. 91). Nesse sentido, Besse considera a visão aérea como uma prova de que a paisagem é essencialmente cultural, pois "demonstra (...) que a paisagem é o produto sempre contingente do encontro entre os homens e a natureza, e ela traduz este encontro" (BESSE, 2014, p. 95).

Mas o avião e a fotografia aérea não se limitam a um instrumento que permite aprofundar o conhecimento geográfico e aperfeiçoar as formas de representação da superfície terrestre e sua relação com a ação humana. 0 trajeto em linha reta possibilitado pelo avião permite atravessar e observar regiões que antes eram inacessíveis. Esse novo ponto de vista torna consciente a fragilidade da ação humana que se coloca sobre uma "base anônima" (BESSE, 2014, p. 94).

Mesmo que a visão de sobrevoo e a fotografia aérea (e, mais recentemente, as imagens de satélite) 
representem uma desejável apreensão ampla do território, uma visão de conjunto, bem como um ganho de precisão na apresentação de seus aspectos, tal ponto de vista implica um afastamento entre observador e mundo e, no contexto de uma ciência positivista, separa cada vez mais a cartografia do conteúdo artístico. A busca pelo conhecimento da "verdadeira" face da Terra deixa de lado as singularidades que caracterizam a relação entre ser humano e superfície terrestre segundo a perspectiva do mundo vivido.

A visão de sobrevoo não se coloca apenas como uma nova tecnologia que permite avanços em distintos campos de conhecimento; ela compõe a mentalidade de uma época, marcada pelo cálculo e pela precisão. Ao ser apropriada por disciplinas que lidam com a intervenção no território, como o Urbanismo, contribui para a construção de espaços pouco abertos à manifestação das singularidades da vida humana (e urbana).

Ao longo do século XX, em contraposição ao afastamento propiciado pela contemplação pela visão de sobrevoo, delimita-se o objetivo de abarcar filosoficamente a realidade sensível do mundo. São elaboradas críticas ao afastamento entre homem e mundo promovido pela ciência positivista, vinculadas ao campo filosófico da fenomenologia, no qual Maurice Merleau-Ponty, no ensaio "O olho e o espírito ", denuncia uma ciência que "manipula as coisas e renuncia habitá-las" (MERLEAU-PONTY, 2004, p. 15).

Retornar às coisas mesmas é retornar a esse mundo anterior ao conhecimento do qual o conhecimento sempre fala, e em relação ao qual toda determinação científica é abstrata, significativa e dependente, como a geografia em relação à paisagem - primeiramente nós aprendemos o que é uma floresta, um prado ou um riacho (MERLEAU-PONTY, 1994, p. 4 ).

Desse modo, concomitante às lógicas de abstração e distanciamento entre homem e mundo, características de um saber científico positivista que se estende ao longo do século XX, manifestam-se outros discursos que se contrapõem a essa postura e tentam resgatar o contato direto com a realidade, em experiência que nem sempre é orientada por um processo resultante de uma racionalização, que provoca abstração e afastamento do contato direto com o real. 


\section{Novas cartografias, novas articulações com a arte}

Ao relacionar novas maneiras de apreender o mundo à prática cartográfica, Jean-Marc Besse resgata a noção de hodologia ${ }^{18}$ em seu ensaio "Paisagem, hodologia, psicogeografia ". Partindo da diferenciação entre uma geografia erudita, na qual o geógrafo ocupa a posição de observador distanciado das coisas e uma segunda geografia caracterizada pelo geógrafo enquanto participante do mundo observado, Besse se refere à hodologia como conteúdo dessa segunda geografia e como ciência das paisagens conformadas pelos caminhos. A cartografia hodológica seria a ferramenta capaz de abarcar esse modo de ver o mundo, marcado pela efemeridade e por um olhar participante.

Frente a um contexto fluido, em que não se fala em representação, mas sim apresentação, explicitação, a cartografia se articula mais uma vez ao campo artístico, o qual explora a potência do caminhar enquanto ação que cartografa o espaço. Nesse sentido, ao longo do século XX são construídas noções em torno do indivíduo caminhante e sua relação com a cidade: o flâneur de Baudelaire; as deambulações das vanguardas modernas; as derivas situacionistas (JACQUES, 2005).

$\mathrm{O}$ ato de cartografar o espaço segundo essa perspectiva consiste em um processo que abarca simultaneamente o conhecimento, a experimentação e a transformação da paisagem, seja simbolicamente ou concretamente. Nesse sentido, essa cartografia supõe o caminhar pela cidade como meio pelo qual se habita o mundo e como prática estética (CARERI, 2013).

No livro Walkscapes, Francesco Careri percorre o significado do caminhar através das práticas artísticas, iniciando pelas excursões aos lugares banais realizadas pelo movimento Dada ${ }^{19}$, que se colocam como questionamento à representação no campo da arte ao priorizar a própria experiência. Careri chama a atenção

18 O termo hodologia deriva de hodos, que vem do grego e significa "caminhos". Foi utilizado pela primeira vez por Derk de Jonge no artigo "Applied Hodology", publicado na revista Landscape (1967-1968) e, posteriormente, foi usado por John Brinckerhoff Jackson em "A la découverte du paysage vernaculaire" (1984) e em "A Sense of Place, a Sence o Time" (1994) (BESSE, 2014).

19 Essa prática teve início com a excursão por Paris realizada em 14 de abril de 1921, partindo da igreja Saint-Julien-le-Pauvre, que foi amplamente divulgada por comunicados à imprensa e documentada com fotografias (CARERI, 2013). 
para um ponto de inflexão na história da arte, sendo que, com o Dada, inicia-se a passagem do "representar a cidade do futuro ao habitar a cidade do banal" (CARERI, 2013, p. 74). Tal prática é encadeada pelas deambulações surrealistas, que diferente das excursões dadaístas, eram realizadas sem um planejamento prévio e ocorriam nos territórios vazios como "bosques, campos, sendeiros e pequenos aglomerados rurais" (CARERI, 2013, p. 78). Os surrealistas interpretavam tais territórios como sujeitos ativos, provocadores de apreensões e como o inconsciente da cidade, "aquelas partes que escapam do projeto e que constituem o que não é expresso e o que não é traduzível nas representações tradicionais" (CARERI, 2013, p. 83).

Posterior às deambulações surrealistas, coloca-se a deriva letrista e situacionista, proposta como subversão do sistema capitalista do pós-guerra e questionamento a respeito da cidade burguesa (questionamento já presente nas excursões dadaístas). A essa cidade, contrapõe-se a cidade lúdica, descrita pelos situacionistas como espontânea, desvinculada das lógicas produtivas e do consumo. Conforme observa Careri, "jogar significa sair deliberadamente das regras e inventar as próprias regras, libertar a atividade criativa das constrições socioculturais, projetar ações estéticas e revolucionárias que ajam contra o controle social” (CARERI, 2013, p. 97).

Careri conclui esse percurso histórico com a produção artística minimalista dos anos 1960, que dá abertura para as propostas da chamada Land Art, representada por artistas como Robert Smithson e Richard Long. Segundo Careri, a manifestação artística que dá início à ideia de Land Art foi o relato de uma viagem realizada por Tony Smith ao longo de uma estrada em construção na periferia de Nova York. Esses artistas retiram a arte dos museus e lidam com territórios de maior escala, criando o que Careri chama de "paisagens artificiais" (CARERI, 2013, p. 122).

Ao observar essa sequência de práticas artísticas relacionadas ao caminhar, Careri identifica os meios pelos quais esses artistas transmitem esteticamente tal experiência. Enquanto os dadaístas e surrealistas se pautam nas descrições literárias, os situacionistas propõem os mapas psicogeográficos, os quais não representam as trajetórias reais dos percursos realizados. Por sua vez, os artistas da Land Art usam o mapa como instrumento expressivo, considerando o corpo como elemento central, seja como instrumento perceptivo, seja como instrumento de desenho. Para falar sobre o papel do corpo e a tradução estética da experiência do caminhar, Careri promove a 
comparação entre dois artistas da Land Art: um deles é Hamish Fulton, que considera o corpo como instrumento perceptivo e utiliza o mapa em sentido abstrato, isto é, por meio de imagens e textos gráficos, considerando que não é possível reproduzir totalmente a experiência do caminhar por meio da representação. O outro artista mencionado é Richard Long, que considera o corpo como instrumento de desenho, sendo o caminhar "uma ação que incide sobre o solo" (CARERI, 2013, p. 133), que pode ser traduzida para ou originada de uma representação cartográfica. Nesse sentido, sobre o trabalho de Richard Long, marcado por intervenções sutis e efêmeras no território, como, por exemplo a linha reta gravada pelo pisoteio da grama em "A line made by walking" (1967), Careri afirma:

O caminhar, além de ser uma ação, é um sinal também, uma forma que pode ser superposta às já existentes tanto na realidade como na carta. Assim, o mundo torna-se um imenso território estético, uma enorme tela sobre a qual desenhar através do caminhar. Um suporte que não é uma folha branca, mas um intrincado desenho de sedimentos históricos e geológicos sobre os quais simplesmente se acrescenta um novo. Percorrendo as figuras superpostas à carta-território, o corpo do viandante anota os eventos da viagem, as sensações, os obstáculos, os perigos, o variar do terreno. A estrutura física do território reflete-se sobre o corpo em movimento (CARERI, 2013, p. 133)

Outro exemplo de apresentação de uma experiência dentro das propostas da Land Art é a obra de Robert Smithson (2009), "The Monuments of Passaic", que consiste em um relato acompanhado de um conjunto de registros fotográficos sobre um percurso realizado em Passaic, Nova Jersey, publicado na revista Artforum em 1967. Smithson propõe uma descrição da cidade considerando os elementos banais de uma paisagem industrial e a experiência pessoal do artista em sua cidade natal. Trata-se de uma leitura da cidade tal como ela é, de seus territórios obsoletos e destituídos de funcionalidades e significados coletivamente construídos por uma cultura dominante. Na verdade, os significados que se sobressaem dizem respeito à memória de um indivíduo que frequenta Passaic, orientado pelo olhar de uma câmera fotográfica e atento aos "monumentos" existentes nesse território suburbano "sem passado" e cheio de "buracos", isto é, "vazios monumentais que definem, sem tentar, os traços de memória de uma série de futuros abandonados" (SMITHSON, 2009, p. 167 ). Esta obra de Smithson consiste em diversos elementos: "o lugar, o percurso, o convite, o artigo, as fotos, o mapa, os escritos precedentes e os escritos posteriores" (CARERI, 2013, p. 140). A obra está tanto na experiência, como na sua representação. 
Observa-se que a cartografia estabelece distintas relações com o modo de apreender o território proposto pelos artistas da Land Art, seja como instrumento de representação complementar a uma experiência impossível de ser sintetizada por um processo de abstração, seja como o próprio processo concreto de intervenção no território. A cartografia apropriada pela Land Art se vincula a uma sequência de questionamentos a respeito da representação no campo da arte, manifestados desde o movimento Dadá, e a uma sequência de abordagens sobre a experiência de uma cidade que não é inteiramente dominada pelo ordenamento, pelo projeto, mas que existe também na indeterminação, no vazio.

Jean-Marc Besse, outro autor interessado pela articulação entre cartografia e as manifestações artísticas, observa que os artistas da Land Art "chegaram à cartografia a partir de um questionamento próprio da arte, relativo às relações que a obra mantém com o real, com o espaço, o tempo, a matéria e, mais geralmente, relativo aos quadros perceptivos e simbólicos da experiência do mundo" (BESSE, 2014, p. 141).

Assim, dentro de suas abordagens específicas, os artistas da Land Art apresentam uma nova articulação entre arte e cartografia, que busca acessar outros espaços, geralmente deixados à margem dos processos econômicos, políticos, culturais e que se manifestam no contexto de uma complexificação da realidade contemporânea, da perda de referências, de fronteiras. Isso fica claro na obra de Smithson sobre Passaic, na qual revela paisagens, atribuindo valor estético a lugares banais, paisagens de margem, artealizando-os.

Autores da década de 1980 expandem a crítica à ciência positivista, que já estava em curso desde a primeira metade do século XX, e às disciplinas que pretendem abarcar a totalidade do mundo (dentre elas, o Urbanismo), organizando-o abstratamente (e o estreitando) e prosseguem com as discussões sobre a experiência construída segundo a inserção do homem no mundo e sobre as práticas não traduzíveis pela linguagem tecnocrática. Tais questões reverberam nas reflexões sobre a cartografia, a qual, articulada às manifestações artísticas que criticavam a lógica produtiva e sua repercussão no cotidiano dos usuários da cidade, aproxima-se cada vez mais do mundo vivido, com intuito de descobrir o que há por baixo das representações generalistas construídas pela visão de sobrevoo. 
O historiador francês Michel de Certeau (2007) dá continuidade a esse pensamento em seu livro "A invenção do cotidiano", introduzido por uma "interrogação sobre as operações dos usuários, supostamente entregues à passividade e à disciplina" (CERTEAU, 2007, p. 37 ). O objetivo de Certeau neste livro é criar condições para que algo tão fugidio como o cotidiano seja "tratável", isto é, passível de análises. Trata-se de

... explicitar as combinatórias de operações que compõem também (sem ser exclusivamente) uma "cultura" e exumar os modelos de ação característicos dos usuários, dos quais se esconde, sob o pudico nome de consumidores, o estatuto de dominados (o que não quer dizer passivos ou dóceis). O cotidiano se inventa com mil maneiras de caça não autorizada (CERTEAU, 2007, p. 38).

O autor propõe um questionamento da sociedade disciplinar descrita por Michel Foucault (2014) em “Vigiar e Punir", na qual a capilarização dos dispositivos de controle dos corpos imprime nos indivíduos comportamentos atomizados cujo funcionamento não depende diretamente de um centro controlador. Para Certeau, pelo contrário, as massas não seriam tão facilmente controladas, tendo em vista suas práticas subversivas, apoiadas em suas próprias interpretações sobre as representações fornecidas por uma cultura dominante.

Partindo das noções da linguística, Certeau desenvolve sua pesquisa considerando que, para se falar dos praticantes comuns, é necessário acessar uma linguagem comum. Assim, Certeau introduz seu estudo relacionando a prática desses usuários comuns ao ato enunciativo e suas quatro características: a operação dentro de um sistema linguístico; a apropriação; a constituição de um presente relativo; o estabelecimento de um contrato com o outro (CERTEAU, 2007, p. 40). Tais características evidenciam a dimensão relacional a partir da qual a pesquisa sobre o cotidiano deve se orientar. Não se trata de apreender os indivíduos de forma atomizada, mas as relações constitutivas de uma sociedade.

Desse modo, o autor explora a potência criativa implícita no conjunto de indivíduos, os "praticantes ordinários" (CERTEAU, 2007, p. 171) e seus modos de operação, as chamadas "práticas microbianas" (CERTEAU, 2007, p.175) das massas multiformes cujas ações são capazes de promover desvios em relação a uma estratégia global. O que o autor chama de "cultura popular" possui suas próprias regras, isto é, "uma maneira de pensar investida numa maneira de agir" (CERTEAU, 2007, p. 42), diferentes modos de leitura que promovem 
a reconfiguração do que é pretendido pelos autores da cultura dominante. A questão que Certeau coloca inicialmente é sobre o que o consumidor fabrica enquanto consome, considerando que o consumo não se limita a uma atividade passiva, que segue exclusivamente os preceitos do fabricante. Pelo contrário, Certeau destaca que essa produção criativa dos consumidores não se coloca fora de um sistema dominador, mas se manifesta dentro dele, subvertendo suas representações segundo práticas sub-reptícias. Essas práticas dizem respeito a uma massa não homogênea composta por indivíduos "não produtores de cultura":

A figura atual de uma marginalidade não é mais a de pequenos grupos, mas uma marginalidade de massa; atividade cultural dos não produtores de cultura, uma atividade não assinada, não legível, mas simbolizada, e que é a única possível a todos aqueles que no entanto pagam, comprando-os, os produtos-espetáculos onde se soletra uma economia produtivista. Ela se universaliza. Essa marginalidade de tornou maioria silenciosa (CERTEAU, 2007, p. 44).

A respeito dessa atividade criativa das massas que se colocam à margem, Certeau contrapõe as ideias de estratégia e tática. Enquanto a estratégia promove seus cálculos ao distinguir um "outro", isolando "um sujeito de querer e poder" de um "ambiente" (CERTEAU, 2007, p. 46), a tática não reconhece essa fronteira com o outro e se desenvolve constantemente segundo as circunstâncias. Assim, Certeau defende que o saber criativo que caracteriza o cotidiano seria um saber tático, que se desenvolve de acordo com os acontecimentos e não possui um plano geral que define um fim específico para uma sequência de ações. Mesmo submetidos a "sintaxes prescritas" (CERTEAU, 2007, p. 45), os produtores do cotidiano constroem frases imprevisíveis.

Em suma, Certeau fala sobre os modos de fazer cotidianos que subvertem a cultura dominante de uma sociedade do espetáculo, na qual predomina o olhar (o que é visível) e, com isso, contesta a suposta relação passiva de escritura-leitura dos consumidores. Seguindo esse fio condutor, Certeau identifica no mapa, entendido como um olhar de sobrevoo característico do "administrador do espaço, o urbanista ou o cartógrafo" (CERTEAU, 2007, p. 171), uma ferramenta de homogeneização e dominação. Isso se torna patente, para o autor, no fracasso dos planos urbanísticos da utopia modernista. Essa visão estratégica de sobrevoo ignora as multiplicidades do espaço das táticas: 
A cidade-panorama é um simulacro "teórico" (ou seja, visual), em suma um quadro que tem como condição de possibilidade um esquecimento e um desconhecimento das práticas. O deus voyeur criado por essa ficção e que, como Schreber, só conhece os cadáveres, deve excluir-se do obscuro entrelaçamento dos comportamentos do dia-a-dia e fazer-se estranho a eles.

Mas "embaixo" (down), a partir dos limiares onde cessa a visibilidade, vivem os praticantes ordinários da cidade. Forma elementar dessa experiência, eles são caminhantes, pedestres, Wandersmänner, cujo corpo obedece aos cheios e vazios de um "texto" urbano que escrevem sem poder lê-lo (CERTEAU, 2007, p. 171).

Nesse sentido, Certeau afirma que a vida urbana se manifesta sob os discursos e ideologias e remonta àquilo que o projeto urbanístico exclui, aos "detritos" de uma "administração funcionalista", isto é, o que se considera "anormalidade, desvio, doença, morte, etc." (CERTEAU, 2007, p. 173). O mapa, para esse autor, seria responsável pela invisibilização da operação, a partir do momento em que pretende torna-la legível.

No que diz respeito às práticas do espaço, Certeau define as "enunciações pedestres" (CERTEAU, 2007, p. 177) como operações impossíveis de serem captadas pela representação do mapa. O autor elege as seguintes modalidades de enunciação pedestre, que explicitam sua irredutibilidade ao traçado gráfico: a modalidade alética, que possui valor de verdade e se refere ao que é necessário, possível, impossível, contingente; a epistêmica, de valor cognitivo e diz respeito ao certo, excluído, plausível, contestável; a deôntica, referente ao dever-fazer, que faz alusão ao obrigatório, proibido, permitido, facultativo. Essas modalidades desdobram as distintas qualidades do caminhar, evidenciando a multiplicidade característica de uma experiência que não se resume a uma trajetória.

Mais condizente com a prática do caminhar, Certeau reconhece no relato um ato que daria conta da experiência contida nas enunciações pedestres, nas retóricas ambulatórias, que consistem em percursos fragmentados e bricolados, divergentes do espaço tecnológico, que é totalizador e coerente (e que prioriza a visibilidade). O relato é "uma prática do espaço" (CERTEAU, 2007, p. 200) que, além de transferir os enunciados pedestres para o campo da linguagem, organiza a caminhada. Os relatos "fazem a viagem, antes ou enquanto os pés a executam" (CERTEAU, 2007, p. 200).

Contemporâneos de Certeau, os filósofos Gilles Deleuze e Félix Guattari (1995) elaboram críticas aos processos de controle instalados pelo capitalismo e ao subjetivismo da psicanálise. As reflexões que esses dois 
autores realizam em conjunto são introduzidas pelo livro "O Anti-Édipo: capitalismo e esquizofrenia" (1972), elaborado no contexto do movimento de maio de 1968 na França. Para os autores, a concepção binária presente na psicanálise de Freud limita a compreensão da realidade e está pautada no próprio sujeito, como se este fosse capaz de construir seus desejos, suas identificações, como se suas produções fossem individuais. Propondo a esquizoanálise, Deleuze e Guattari consideram que tudo se trata de produções inseridas em um grupo, em uma história. Não diz respeito à uma família (que ocupa lugar tão preponderante na psicanálise de Freud), mas à civilização (AGOSTINHO, 2017).

...para Deleuze e Guattari, as identificações pensadas a partir da esquizofrenia não se restringem ao par, papai-mamãe e suas repetições na vida social. Elas são primeiramente sociais e históricas, assim como o sexo é múltiplo. O esquizo delira com as raças, os continentes e a história porque os investimentos sociais são sempre de grupo, nunca individuais e se endereçam à história e à geografia (AGOSTINHO, 2017, p. 405)

Os autores apresentam uma postura crítica frente a toda forma de conhecimento pautada na relação de causa e efeito, que busca explicações e que identifica a realidade segundo representações, estruturas. Nesse sentido propõem o conceito de "corpo sem órgãos" (DELEUZE, GUATTARI, 1995, p. 22), que se refere àquilo que não foi determinado por funções e que está aberto a afetos múltiplos e em processo constante de produção.

Enquanto Certeau considera a ação dos sujeitos ordinários dentro de um sistema, cujas leis são subvertidas e cujos percursos são imprevisíveis, Deleuze e Guattari parecem abolir definitivamente esse sistema como fator determinante na produção da realidade. Tal questão fica clara também, ao constatarmos que Certeau se apoia no campo da linguagem para construir sua análise sobre a cultura popular e as operações que caracterizam o cotidiano, enquanto Deleuze e Guattari questionam o papel dominante da linguagem nos comportamentos, pois consideram que nem tudo é transformado em linguagem e nem tudo é transmitido, isto é, exposto ao outro (AGOSTINHO, 2017).

No livro "Mil Platôs", visando uma explicitação das múltiplas relações que constroem a realidade de seu tempo, Deleuze e Guattari expandem suas reflexões segundo a ideia de Rizoma, uma imagem a partir da qual os autores buscam criticar os modelos de pensamento vigentes. O rizoma seria algo distinto de um sistema-radícula 
que apresenta uma raiz principal, um pivô, um eixo; pelo contrário, ilustra aquilo que não é linearmente concebível, que não possui começo ou fim. Diz respeito ao emaranhado de condições (significados, determinações, forças, identidades) que caracterizam a vida e que evidenciam seu caráter criativo e processual.

Trata-se de uma imagem adotada pelos autores para apresentar a complexidade da contemporaneidade, segundo seis princípios: conexão, heterogeneidade - "qualquer ponto de um rizoma pode ser conectado a qualquer outro e deve sê-lo" (DELEUZE; GUATTARI, 1995, p.15); multiplicidade- "é somente quando o múltiplo é efetivamente tratado como substantivo, multiplicidade, que ele não tem mais nenhuma relação com o uno como sujeito ou como objeto, como realidade natural ou espiritual, como imagem e mundo" (DELEUZE; GUATTARI, 1995, p.16); ruptura a-significante- "contra os cortes demasiado significantes que separam as estruturas, ou que atravessam uma estrutura" (DELEUZE; GUATTARI, 1995, p.18); cartografia e decalcomania - "um rizoma não pode ser justificado por nenhum modelo estrutural ou gerativo. Ele é estranho a qualquer ideia de eixo genético ou de estrutura profunda" (DELEUZE; GUATTARI, 1995, p.21).

Dentro dessa reflexão teórica, que concebe uma realidade segundo seu aspecto processual, incompatível com estruturas que organizam e limitam determinados comportamentos e identidades, Deleuze e Guattari apresentam a ideia de mapa como representativa dessa realidade rizomática, construída por multiplicidades, por corpos sem órgãos.

Atentando para o quinto e sexto princípios citados anteriormente, percebe-se que os autores apresentam uma postura divergente de Certeau no que diz respeito ao termo mapa ou cartografia, não mais associada a uma visão de sobrevoo:

Se o mapa se opõe ao decalque é por estar inteiramente voltado para uma experimentação ancorada no real. O mapa não reproduz um inconsciente fechado sobre ele mesmo, ele o constrói. Ele contribui para a conexão dos campos, para o desbloqueio dos corpos sem órgãos, para sua abertura máxima sobre um plano de consistência. Ele faz parte do rizoma. O mapa é aberto, é conectável em todas as suas dimensões, desmontável, reversível, suscetível de receber modificações constantemente. Ele pode ser rasgado, revertido, adaptar-se a montagens de qualquer natureza, ser preparado por um indivíduo, um grupo, uma formação social. Pode-se desenhá-lo numa parede, concebê-lo como obra de arte, construí-lo como uma ação política ou como uma meditação. (...) Um mapa tem múltiplas entradas contrariamente ao decalque 
que volta sempre "ao mesmo". Um mapa é uma questão de performance, enquanto que o decalque remete sempre a uma presumida "competência" (DELEUZE; GUATTARI, 1995, p. 22).

A cartografia para esses autores seria menos uma representação (uma expressão gráfica) e mais um processo de construção e transformação. Apesar das definições distintas de Certeau e Deleuze e Guattari sobre o mapa, todos esses autores exploram um modo de apreender a realidade que parte do fenômeno, que considera suas multiplicidades. Todos eles criticam o caráter reducionista de certas formas de representação que ocultam o processo, a performance, a operação.

Diversos autores vinculados ao campo do urbanismo, das artes, da geografia, da psicologia, entre outros, tem procurado traduzir a abordagem rizomática de Deleuze e Guattari para seus campos disciplinares. Assim, as discussões sobre a paisagem, articuladas à cartografia, também vem sendo contaminadas pela reflexão desses autores. A busca por um modo de apreender a paisagem enquanto ideia plural, não restrita a funções e concepções hegemônicas encontra um campo de exploração promissor nas reflexões desses autores (desde a discussão no campo da arte sobre o caminhar, até as críticas elaboradas por Certeau e Deleuze e Guattari).

Às vésperas do novo milênio, Denis Cosgrove (1999), em introdução à coletânea de ensaios intitulada "Mappings", identifica a necessária revisão da cartografia enquanto representação, devido às transformações da realidade global e ao modo como ela passa a ser representada.

No mesmo livro, no ensaio "The agency of mapping", o arquiteto paisagista James Corner (1999) 20 argumenta a necessidade de se pensar o mapa como processo que descobre e revela potênciais, enriquece experiências e diversifica mundos, frente a uma realidade contemporânea que borra os limites do que é real e o que é representação. Seguindo as reflexões de Deleuze e Guattari, Corner insiste na ideia de que o mapa é diferente de um decalque.

Segundo o autor, o mapa apresenta duas características contrastantes: ao mesmo tempo que é análogo a

20 James Corner está a frente do escritório James Corner Field Operations estabelecido em Nova York, sendo um de seus projetos realizados o High Line Park (Nova York). 
uma realidade, é também abstração de algo que não é diretamente acessível ao olhar humano. O mapa é capaz de articular fenômenos aparentemente incongruentes, promovendo a reapresentação de realidades. Nesse sentido, o mapa seria como uma "mesa de operação" (operating table), "um palco ou um teatro de operações sobre o qual o cartógrafo (mapper) recolhe, combina, conecta, marca, relaciona e geralmente explora" ${ }^{21}$.

O autor reconhece o engajamento do campo artístico nessa abordagem do mapa, mas denuncia a necessidade de uma atualização nos processos de projeto e planejamento. De maneira geral, Corner identifica que a arquitetura e o urbanismo ainda se encontram presos à concepção quantitativa do mapa, que é considerado como conjunto de dados neutros a partir dos quais é pensada a intervenção no espaço. Em contraposição a esse perfil, o autor destaca que o mapa não é anterior ao projeto, mas já é processo criativo e de intervenção. Não é neutro, pois envolve uma série de escolhas e julgamentos.

Trata-se de abordagem semelhante à de Besse (2014) no ensaio "Cartografar, construir, inventar ", no qual o autor discorre sobre a cartografia a partir da ideia de diagrama, "uma entidade intelectual que é, ao mesmo tempo, ideia e imagem, processo de construção e figura resultante da construção, processo mental e ato gráfico" (BESSE, 2014, p. 153). Tal concepção atribui à cartografia um caráter criador, visto que seu processo de elaboração já supõe leituras, interpretações e escolhas. Nesse sentido, este ensaio de Besse intenta expor a lógica por trás do processo de invenção, articulando-a à prática cartográfica.

James Corner prossegue com sua reflexão apontando quatro temáticas emergentes na prática cartográfica, identificadas como estratégias de abordagem projetual: drift (exemplificada pelos mapas psicogeográficos dos situacionistas), layering (presente no processo de projeto do Parc de la Villette de Bernard Tschumi), game-board (referente a processos criativos coletivos), rhizome (retomando a ideia desenvolvida por Deleuze e Guattari a respeito de uma apreensão da realidade como algo sem uma estrutura hierárquica, em constante expansão).

Tais temáticas explicitam a fluidez e complexidade do contexto contemporâneo e as tentativas em

$21 \quad$ No original "...a staging ground or a theatre of operations upon which the mapper collects, combines, connects, marks, relates and generally explores" (CORNER, 1999, p. 215). 
apreender essa multiplicidade a partir de um esforço de criação, reapresentando-a.

Outra abordagem da cartografia enquanto processo criativo está no livro "Atlas ou a Gaia Ciência Inquieta" de autoria do filósofo e historiador Georges Didi-Huberman (2013), o qual apresenta uma reflexão acerca do atlas enquanto modo de apresentação e leitura do mundo e suas multiplicidades, que diverge de uma tradição platônica que define o conhecimento verdadeiro segundo uma purificação do mundo sensível. Neste livro, Didi-Huberman explora minuciosamente as questões contidas na obra Mnemósine de Aby Warburg, que foi iniciada em 1924 e se manteve incompleta com sua morte em 1929. Segundo Didi-Huberman, a obra traz uma arqueologia sobre a história da arte, baseada essencialmente nos gestos humanos e sua elaboração é realizada no contexto caótico pós Primeira Guerra Mundial, bem como da contestação da ciência positivista ${ }^{22}$.

O título do livro de Didi-Huberman faz referência a Friedrich Nietzsche (1844 - 1900), em "A Gaia Ciência" e sua crítica à ciência positivista. O filósofo define essa nova ciência relacionada ao perfil errante, instável, desenraizado, inquieto de sua época, que iniciava os questionamentos sobre uma forma de conhecimento que se distanciava do mundo sensível. O atlas seria uma forma visual do saber em contínua elaboração que articula questões diversas e subverte as formas canônicas. "É uma ferramenta, não do esgotamento lógico das possibilidades dadas, mas da inesgotável abertura às possibilidades não dadas ainda" (DIDI-HUBERMAN, 2013, p. 13). Tem como princípio a imaginação, que

...aceita o múltiplo e renova-o sem cessar, a fim de aí detectar novas "relações íntimas e secretas", novas "correspondências e analogias", que serão por seu turno inesgotáveis, como inesgotável é todo pensamento das relações que uma montagem inédita será sempre suscetível de manifestar (DIDI-HUBERMAN, 2013, p. 14).

O autor utiliza a imagem da "mesa" para apresentar esse processo de conhecimento ao qual sempre

22 "O atlas de imagens Mnemósine seria, pois, a resposta, a abertura inventada por Aby Warburg face aos fechamentos metodológicos do positivismo, bem como aos entrincheiramentos políticos dos nacionalismos culturais exacerbados com a Grande Guerra" (DIDI-HUBERMAN, 2013, p. 171). "Mnemósine é, pois, uma obra-prima - comovedora aposta epistêmica, forma nova de saber visual - onde tudo o que está reunido, recolhido, liberta multiplicidades de relações impossíveis de reduzir a uma síntese. É a obra de uma salutar crise da unidade e de uma necessária crise da totalidade, um conjunto de mesas que reúnem a fragmentação do mundo das imagens, para além de toda a esperança - idealista ou positivista - de síntese" (DIDI-HUBERMAN, 2013, p. 233). 
se pode retornar, que se distingue do "quadro", do "arquivo" ou da "caixa", todos definitivos e acabados, cujo conteúdo se encontra empilhado e, portanto, dificilmente relacionável. Esse modo de ler o mundo articula sua ordem e desordem; sua razão e desrazão; o que está "entre os astra do que nos eleva até o céu do espírito e os monstra do que nos precipita até às profundezas do corpo" (DIDI-HUBERMAN, 2013, p. 21). Nesse sentido, a mesa enquanto "campo operatório" que reúne elementos díspares, permite apresentar o correlato à fragmentação do mundo. Inegável a semelhança com o rizoma de Deleuze e Guattari, os quais são mencionados pelo historiador ao longo do desenvolvimento de seu livro.

De modo geral, Francesco Careri, James Corner, Didi-Huberman, Jean-Marc Besse, são autores que, em seus distintos campos disciplinares (arquitetura e urbanismo, história, filosofia e geografia), explicitam o ponto de contato entre arte e ciência, cartografia e paisagem, nesses diversos modos de ver o mundo que se manifestam ao longo do século XX e que se prolongam no contexto contemporâneo. Na sequência a uma racionalização acentuada da observação e representação do território no contexto de uma ciência positivista, a cartografia do século XX torna a se articular à arte, transformando-se em ferramenta capaz de explorar, explicitar e transformar o mundo.

Nas discussões que abordam a cartografia em um contexto contemporâneo, evidencia-se sua dimensão enquanto processo. Mais que uma forma de representação, uma imagem concluída que busca abarcar uma totalidade, a cartografia seria reconhecida em seu caráter criativo. É definida, nesse sentido, pelo seu processo de elaboração, que já inclui um projeto de intervenção e transformação da realidade.

Essa cartografia seria o ponto de partida para pensar um método de projeto da paisagem, que abarque as complexidades e as diversas camadas objetivas e subjetivas que constroem a realidade contemporânea. A cartografia enquanto método estaria entre forma de representação, apresentação e transformação da paisagem. E ainda, consistiria em um processo inconcluso, em contínua elaboração. 


\section{PROJeto}

\section{Projetar a paisagem na contemporaneidade}

Na virada do século XIX para o XX, a disciplina do urbanismo se constituiu a partir de intenções de organização do território, segundo princípios de higiene, circulação e estética, vinculados à dimensão econômica (COSTA, 2003 ). Tais princípios foram reconfigurados ao longo da história segundo as transformações técnicas, sociais e culturais, no entanto, permanecendo até os dias atuais. "A questão urbana "nasce" (...) em meio a rede de dados cifrados numericamente e diagramas. A dissolução da cidade em concepção do urbano, como meio no qual se entrecruzam os órgão técnicos, equipamentos coletivos e componentes do solo formou a base do urbanismo como disciplina" (BRESCIANI, 2017, p. 121 ).

As intenções de organização do território vão sendo retomadas pelos urbanistas em distintas épocas; desde a "sociedade disciplinar" da modernidade, referente ao momento formador de uma mentalidade burguesa que busca lidar com as recentes aglomerações urbanas, no sentido sanitarista de disciplinar o espaço urbano e seus habitantes, principalmente a classe trabalhadora, até a contemporânea "sociedade do controle", termo utilizado por Deleuze para denominar a realidade fluida que, após a Segunda Guerra, vem substituir a sociedade disciplinar (BRESCIANI, 2017). O que se mantém é o esforço de sistematizar um funcionamento da cidade que configure um espaço eficiente, dentro dos limites da lógica produtiva.

A complexidade da cidade contemporânea exige uma transposição desses limites e uma aproximação com a dimensão cotidiana. Pensar as questões do projeto no campo da arquitetura da paisagem sobre bases contemporâneas exige o distanciamento de procedimentos pautados estritamente por questões utilitaristas ou funcionais. A abordagem da cidade contemporânea diz respeito às múltiplas dinâmicas que ocorrem no espaço, as quais não se limitam a aspectos que podem ser abarcados por métodos que observam o território do exterior, de cima, para então destinar intervenções de "revitalização", "requalificação", "melhorias" em pedaços da cidade. 
Pelo contrário, parece mais adequada a abordagem projetual bottom-up, que vem de baixo para cima ${ }^{23}$.

Diante disso, seria procedente o questionamento da postura dos profissionais da arquitetura e urbanismo frente a esse contexto, no qual as apropriações do espaço fogem a esforços racionalizadores. Pretende-se realizar uma investigação que busca endereçar intenções projetuais à paisagem considerando uma abordagem que ultrapassa as questões eminentemente técnicas, a potencial espetacularização ${ }^{24}$, a inserção do espaço nas lógicas produtivas e de consumo que predominam na cidade.

Projetar a paisagem supõe lidar com as complexidades que o termo abarca. Entre subjetividade e objetividade, objeto de contemplação e banalidade, a paisagem corresponde ao mundo vivido e sua pluralidade de significados e materialidades. O projeto endereçado a esse mundo inevitavelmente será constituído à luz dessa complexidade que reúne questões socioculturais, econômicas, políticas e ambientais.

Tendo por base o elaborado até o momento, não parece adequado se referir ao projeto da paisagem apenas como intervenção estética, ou segundo o ponto de vista estritamente ecológico e assim por diante. A intervenção na paisagem que não promove generalizações e simplificações lida com potencialidades, articula elementos de distintas naturezas.

Em relação ao campo artístico, este aparece desvinculado de obrigações funcionais e parece ser o âmbito mais compatível com as paisagens que se desdobram na contemporaneidade, visto que promove leituras, modos de ver o mundo, segundo outros valores, reapresentando-o enquanto paisagem. Nesse sentido, mostra-se complexa a abordagem projetual frente a essas paisagens banais, paisagens de margem, considerando o histórico de construção da disciplina.

23 Francesco Careri menciona a perspectiva bottom-up ao discorrer sobre as práticas iniciados pelo biólogo escocês Patrick Geddes (1854 - 1932), referência em planejamento urbano e autor do livro "Cities in Evolution. An introduction to the Town Planning Movement and to the Study of Civics". Careri define essas práticas como "o nascimento de uma nova disciplina ainda inexistente: a urbanística itinerante, uma ciência cívica que propõe aos estudantes e aos futuros planners a imersão direta em suas obras" (CARERI, 2017, p. 95). 24 O conceito de espetacularização "está diretamente relacionado a uma diminuição da participação popular, mas também da própria experiência física urbana enquanto prática cotidiana, estética ou artística..." (JACQUES, 2005, p. 16). 
Conforme observam Aliata e Silvestri, "na crise atual do pensamento sobre a cidade e o território, as obras mais interessantes que utilizam a paisagem como material determinante provém das artes plásticas, que tratam de sair dos modos tradicionais para trabalhar diretamente com a grande escala ambiental" (ALIATA; SILVESTRI, 2008, p. 193).

Como explicitado no capítulo anterior, as manifestações artísticas frente a essa realidade contemporânea são diversas. Cumpre explorar essa abordagem nas disciplinas que tem como pressuposto essencial a intervenção no território.

Na década de 1970, o arquiteto norueguês Christian Norberg-Schulz (2013) transfere o discurso da fenomenologia para o projeto arquitetônico, usando como principal referência o filósofo alemão Martin Heidegger (1889 - 1976), ao mesmo tempo em que promove uma crítica à ciência que realiza abstrações e cria conceitos neutros. Argumentando a urgente necessidade de uma fenomenologia da arquitetura, Norberg-Schulz afirma que o arquiteto seria capaz de concretizar as essências dos lugares, considerando o que constitui o "mundo-da-vida cotidiana" (NORBERG-SCHULZ, 2013, p. 445 ), que não se resume a elementos concretos e a funções. Segundo o autor, um lugar reúne o que há de concreto - forma, textura e cores - e o que há de menos tangível, constituindo uma "qualidade ambiental". Entendido como uma totalidade desses fatores, o lugar seria irredutível a uma de suas propriedades. Sua estrutura é explicitada por três categorias qualitativas e que se referem à dimensão espacial: os fenômenos naturais e os fenômenos fabricados pelo homem; as relações terra-céu e fora-dentro; o caráter, uma noção que exprime a relação entre uma "atmosfera" e uma dimensão concreta, que Norberg-Schulz exemplifica com expressões como "paisagem sorridente", "paisagem ameaçadora" (NORBERG-SCHULZ, 2013, p. 451).

Partindo da definição do que seria um lugar, o autor reconhece no ato de construir um modo de "revelar os significados presentes de modo latente no ambiente dado" (NORBERG-SCHULZ, 2013, p. 454), apoiando sua ideia na fala de Heidegger a respeito de uma ponte sobre um rio:

A ponte se estende lépida e forte sobre o rio. Ela não junta as margens que já existem, as margens é que surgem como margens somente porque a ponte cruza o rio. É a ponte propriamente dita que faz com que as margens fiquem uma defronte da outra. É pela ponte que um lado se opõe ao outro. Tampouco as 
margens correm ao longo do rio como faixas de fronteira indiferentes da terra firme. Com as margens, a ponte leva ao rio as duas extensões de paisagem que se encontram atrás delas. Põe o rio, as margens e a terra numa vizinhança recíproca. A ponte junta a terra, como paisagem, em torno do rio (HEIDEGGER, 1971, p. 152 apud NORBERG-SCHULZ, 2013, p. 453).

Assim, a construção, obra humana, confere valor aos elementos do mundo. É possível notar que essa noção apresentada por Norberg-Schulz se aproxima da abordagem de Eric Dardel, segundo o qual a Terra só adquire significado com a presença humana; a realidade geográfica enquanto tal depende das relações e perspectivas propiciadas pela vida do ser humano no mundo. Trata-se de uma postura que, conforme se vincula às reflexões da fenomenologia, busca reconhecer o mundo articulando seus aspectos concretos, pré-existentes ou construídos, e seus aspectos subjetivos (indissociáveis da presença humana, portanto, referentes a uma construção cultural) que, em conjunto, engendram o mundo vivido. Cumpre salientar que Norberg-Schulz é um dos primeiros autores a falar sobre o campo da arquitetura segundo essa perspectiva.

Uma abordagem contemporânea dessa qualidade é identificada nos projetos do arquiteto da paisagem francês Bernard Lassus, que trabalha com aspectos diversos de um lugar, significados, percepções, materialidades, promovendo novas leituras, geralmente com intervenções sutis que revelam paisagens. Para esse arquiteto, a paisagem é constituída por fragmentos, é o não visível e o visível; o visto e o escondido; o percebido e o recordado, imaginado (LASSUS apud BAGLIANI, 2010, p. 33). Portanto, reúne as dimensões subjetivas e objetivas da paisagem, para pensar em termos de intervenção, isto é, projeto.

Em "L'obligation de l'invention" (1994), ensaio apresentado no livro "Cinq propositions pour une théorie du paysage" organizado por Augustin Berque, Lassus discorre sobre algumas de suas reflexões acerca do projeto da paisagem e uma das questões apresentadas diz respeito à diferenciação entre "escala visual" e "escala tátil". Enquanto a escala visual se concentra em fenômenos estritamente visuais, a escala tátil compreende, além da dimensão visual, outros aspectos do mundo físico e representa o encontro direto com as coisas. Nesse sentido, o projeto da paisagem de Lassus se relaciona com a abordagem fenomenológica da paisagem, pois considera os fatores externos que afetam o corpo, bem como o corpo em movimento que percebe o lugar. 
James Corner é outro autor no campo da arquitetura paisagística que reconhece a insuficiência da imagem para se considerar o projeto da paisagem. Segundo o autor, o processo criativo a partir do qual se concebe a paisagem é eidético, "uma concepção mental que pode ser picturável mas deve ser igualmente acústica, tátil, cognitiva ou intuitiva" 25. Mesmo que o autor reconheça o papel central da imagem no processo de criação de paisagens, Corner argumenta que a paisagem não se limita à contemplação e afirma que não se deve priorizar sua dimensão formal e visual.

Nesse sentido, Corner destaca o papel ideológico da imagem, que não é neutra nem passiva. Por mais que seu conteúdo ideológico tente ocultar os processos que motivaram sua formação, essa imagem dominante não deixa de ser quebrada por "ironias do cotidiano" (everyday ironies): "máquinas em jardins, caminhões de extermínio em subúrbios ruralizados, moradores de rua em centros cívicos e lixo na escadaria da igreja" ${ }^{26}$.

Considerando que o paisagista lida com os processos de formação da paisagem, em sua dimensão de engajamento, Corner afirma que seu papel, menos do que representar, é facilitar, instigar e diversificar esses processos no tempo. Nesse sentido, o autor observa que "... a constituição da paisagem é inerentemente instável, uma dimensão indeterminada que pode ser aberta por meio das práticas artísticas de modo a revelar conjuntos alternativos de possibilidades" 27.

Outro tema projetual abordado por Lassus diz respeito à noção de "intervenção mínima" (intervention minimale) (LASSUS apud BAGLIANI, 2010, p. 30), que consiste em intervenções que não são necessariamente físicas. Na realidade, propõe releituras, modos de apresentação de paisagens que já existem concretamente, mas que podem ser percebidas de modos alternativos, ao se questionar a leitura habitual de um lugar.

25 No original: "a mental conception that may be picturable but may equally be acoustic, tactile, cognitive, or intuitive" (CORNER, 1999, p.153)

26 No original: "Machines in gardens, extermination trucks in countrified suburbs, homeless people in the civic center, and garbage on the church steps" (CORNER, 1999, p. 157).

27 No original: "... the landscape construct is inherently unstable, an indeterminate dimension that can be opened up through artistic practices and made to reveal alternative sets of possibility" (CORNER, 1999, p. 158). 
Seus projetos apoiam-se em uma "análise inventiva" (analyse inventive) (LASSUS apud BAGLIANI, 2010, p. 42), que consiste em explorar as singularidades e potencialidades de um lugar, investigação que é realizada primeiramente segundo uma "atenção flutuante" (attention flottante) (LASSUS apud BAGLIANI, 2010, p. 42), que lida com as escalas visual e tátil, considerando os significados historicamente construídos do lugar.

Francesco Careri também apresenta proposições para o projeto em Arquitetura e Urbanismo, em seu livro "Caminhar e Parar", no qual dá maior atenção à interação com os habitantes dos chamados "Territórios Atuais", lugares explorados pelo grupo Stalker. Seguindo as ideias centrais de sua trajetória de pesquisa sobre o caminhar enquanto prática estética, Careri argumenta que o campo projetual deve estar vinculado ao fazer artístico.

Ao retomar as questões abordadas pelo grupo Stalker e seu interesse pelos espaços vazios da cidade, o arquiteto italiano compreende que esses espaços vazios possuem lógicas próprias e não devem ser saturados, isto é, preenchidos, seja por edificações, seja por significados. O que deve ser feito, na visão de Careri, é garantir o devir desses espaços, uma "variante de abandono", sendo a arte a "chave de leitura" capaz de captar os valores contidos nessas paisagens (CARERI, 2017, p. 24).

A arte não assusta nem os habitantes nem o poder; é recebida como uma atividade inócua, talvez até inútil, sem poder, sem capacidade projetual. Essa é sua grande força. A arte é capaz de pegar desprevenida a cidade, pegá-la de modo indireto, lateral, lúdico, não funcional, de tropeçar em territórios inexplorados, em que nascem fenômenos e novas questões, de entender seus valores simbólicos e de produzir ações e imaginários imateriais, muitas vezes mais úteis do que a planificação e a edificação física dos lugares (CARERI, 2017, p. 60)

A proposta do grupo Stalker tem sido percorrer esses espaços vazios, atravessá-los, de modo a observar de fora a cidade "plena", no entanto, a partir de lugares imersos nas lógicas que estruturam o tecido urbano. $\mathrm{O}$ ato de caminhar pelos vazios é encarado por Careri como uma prática desvinculada de certas concepções prévias, sobretudo sobre a noção de propriedade. Não se trata de caminhar pelas calçadas e ruas, mas justamente atravessar os vazios, mesmo que o acesso seja proibido, mesmo que a propriedade seja particular.

Nas cidades de hoje, que se transformam tão rapidamente, sem que os moradores percebam e que explodem em miríades de enclaves no território extraurbano, caminhar e atravessar os confins tornou-se 
(...) o único modo de reconstrução de um fio unitário para os fragmentos de cidades separadas nas quais vivemos. Caminhar tornou-se o instrumento estético e científico que permite reconstruir o mapa em devir das transformações em curso, uma ação cognocitiva, capaz de acolher inclusive aquelas amnésias urbanas que, inconscientemente, apagamos de nossos mapas mentais porque não as reconhecemos como cidades (CARERI, 2017, p.101-102).

Ao final do livro, Careri apresenta um glossário relacionado a uma "metodologia do tema do caminhar e parar" (CARERI, 2017, p. 113), estabelecida segundo seus anos de experiência como professor e pesquisador do Departamento de Arquitetura da Università degli Studi Roma Tre, onde dirige o grupo de pesquisa Laboratorio Arti Civiche. Dentre as palavras e expressões apresentadas, estão metodologia, que deve ser entendida não como algo dogmático e estático, mas como um caminho, algo que é construído ao longo de um processo ${ }^{28}$; projeto, enquanto algo que não é finito e se mantém indeterminado; tropeçar, que define um caminhar realizado de "modo estrábico, com um olho na rota e outro em tudo aquilo que o tira da rota" (CARERI, 2017, p. 116 - 117); perder tempo=ganhar espaço, ideia que retoma o discurso dos flâneurs e que se atualiza na cidade contemporânea, como modo de conhecer o território que não se estrutura por um percurso pré-determinado; terreno de jogo, que consiste numa exploração sem expectativas, não funcional, mas lúdica, em conjunto com o Outro; provocar, referente ao ato de revelar o que está embaixo de uma "camada de banalização", na qual se escondem "o Outro e o Alhures" (CARERI, 2017, p. 121), deslocar pontos de vista e convenções; One to one, que diz respeito à relação entre corpo e cidade ${ }^{29}$.

É possível constatar que Lassus e Careri, ambos pertencentes ao campo projetual da arquitetura, desenvolvem lógicas de intervenção na paisagem que buscam quebrar processos de leitura habituais e inaugurar novos que tornem visíveis certas paisagens que historicamente estiveram à margem das elaborações projetuais.

28 Aqui Careri aceita a definição dada por Paola Berenstein Jacques, que entende "metodologia" segundo a etimologia da palavra método, que "deriva do grego methòdos (metà = depois, através; hòdos = via, caminho): "depos do caminho", mas também "através do caminho". A metodologia pertence indiscutivelmente ao caminhar, ela é construída "ao longo do caminho", "ao caminhar", e o método se compreende "enquanto se está procedendo"" (CARERI, 2007, p. 115).

29 O glossário compreende as seguintes palavras e expressões: metodologia, projeto, indeterminado, não se deve voltar atrás, tropeçar, perder tempo=ganhar espaço, o Outro, participação, pesquisa de campo, ativar processos, reterritorializar, terreno de jogo, provocar, deslocar, cuidadoria, corpo, One to One, saudar, fim (CARERI, 2017, p. 113 -124). 
Os autores não buscam preencher tais paisagens originalmente invisíveis, mas trabalhar com suas qualidades próprias.

A proposta desse trabalho é promover uma investigação acerca de uma possível abordagem que parece condizer com a multiplicidade que é a paisagem. Abarcar os diversos aspectos da cidade de modo a agencia-los para elaborar diretrizes projetuais, supõe a adoção de operações e ferramentas compatíveis. Nesse sentido, a cartografia se coloca como método capaz de representar, apresentar e reorganizar características objetivas e subjetivas da paisagem.

\section{Uma proposta de estratégia metodológica de projeto da Paisagem}

Partindo das reflexões de Deleuze e Guattari, são vários os autores que propõem a cartografia enquanto método e desenvolvem uma estratégia de estudo da esfera da vida pela perspectiva de vários campos disciplinares. Tais pesquisas tem sido desenvolvidas em campos como sociologia (ROLNIK, 2006) ${ }^{30}$, psicologia (ROMAGNOLI, 2009; KASTRUP; PASSOS; ESCÓSSIA, 2015), geografia (WYLIE, 2007) ${ }^{31}$ e arquitetura e urbanismo (JACQUES; BRITTO; DRUMMOND, 2015) ${ }^{32}$.

30 Em "Cartografia sentimental" Suely Rolnik elabora uma reflexão sobre os processos de subjetivação enquanto construção coletiva. Foi escrito no contexto da instalação do neoliberalismo na década de 1980 e explora os perfis de subjetividade, sobretudo no que tange à mulher, que se manifestaram na forma de resistência ao longo da transformação da sociedade disciplinar do modelo fordista. Sua escrita é desenvolvida fora dos padrões convencionais, propondo uma maneira alternativa de apresentar uma pesquisa em diálogo com seus trabalhos desenvolvidos com Guattari.

31 No capítulo final do livro "Landscape", John Wylie promove uma reflexão sobre os discursos nascentes sobre a paisagem nos Estados Unidos e no Reino Unido. Uma das vertentes identificadas, abordadas no contexto britânico, diz respeito ao "vitalismo" (vitalism), filosofia associada a Gilles Deleuze que considera o espaço em seu aspecto relacional, em constante processo de criação e transformação e que se coloca como oposição à fenomenologia heideggeriana, a qual concebe a paisagem como algo estático e sedentário, segundo as noções de habitar (dwelling) e ser-no-mundo (being-in-the-world) (WYLIE, 2007).

32 A coletânea "Experiências Metodológicas para a compreensão da complexidade da cidade contemporânea" é resultado de uma pesquisa realizada pelo grupo Laboratório Urbano, do Programa de Pós-Graduação em Arquitetura e Urbanismo da FAUFBA (UFBA) e se refere ao questionamento das metodologias tradicionalmente utilizadas no campo do Urbanismo, buscando investigar as complexidades da cidade contemporânea. 
Parte dessas pesquisas abarcam predominantemente questões subjetivas, relacionadas ao comportamento humano e a interação entre indivíduos e grupos de indivíduos. No caso de disciplinas que trabalham com a articulação entre as esferas subjetiva e objetiva, principalmente na arquitetura e urbanismo, que não lida apenas com leituras, mas com intervenções concretas na paisagem, o desafio está em apreender aspectos múltiplos e efêmeros sem fixa-los e simplifica-los.

As discussões elaboradas nos outros campos de conhecimento podem auxiliar a pensar a cartografia enquanto método, tendo em vista inclusive a aproximação dessa abordagem com discursos e práticas de arquitetos e urbanistas. As questões trazidas por James Corner, Francesco Careri e Bernard Lassus, apresentam consonâncias com essas ideias.

Uma das questões centrais para que as pesquisas se apropriem da cartografia enquanto estratégia metodológica, diz respeito à aproximação do pesquisador com seu campo. Ele deve estar inserido nesse campo, de modo a observar e interagir com as lógicas que caracterizam seu objeto de estudo, evitando a relação distanciada que determina o pesquisador como observador alheio às linhas de força que compõem um território (seja no sentido físico, seja no simbólico).

A cartografia se apresenta como valiosa ferramenta de investigação, exatamente para abarcar a complexidade, zona de indeterminação que a acompanha, colocando problemas, investigando o coletivo de forças em cada situação, esforçando-se para não se curvar aos dogmas reducionistas (...). Mais do que procedimentos metodológicos delimitados, a cartografia é um modo de conceber a pesquisa e o encontro do pesquisador com seu campo (ROMAGNOLI, 2009, p.169).

A imersão no campo poderia ser entendida segundo essas duas perspectivas: uma delas, relacionada principalmente a estudos da sociologia e psicologia, parte de uma abordagem etnográfica e estabelece como central a interação do pesquisador com as populações. A outra perspectiva, identificada principalmente no campo da arquitetura e urbanismo, diz respeito à aproximação com o mundo concreto, articulando-o ao seu conteúdo simbólico. As duas perspectivas parecem essenciais para contornar processos de projeto que observam o território de cima, desconsideram características específicas de um lugar e se restringem a leituras habituais da paisagem. 
Em arquitetura e urbanismo, de fato, a interação com as populações que conformam um território é essencial para o desenvolvimento de um projeto que seja construído como um desdobramento das dinâmicas já estabelecidas. Principalmente se as compreendermos como disciplinas cujas intenções originárias estão sendo questionadas, isto é, os propósitos de organização e controle do espaço, em que os indivíduos detentores do saber técnico definem como a cidade deve funcionar, desconsiderando as pluralidades que caracterizam a vida urbana.

No entanto, é central também a exploração desse território segundo uma perspectiva de criação, de desestabilização de leituras consolidadas, que podem ocultar certas paisagens que se colocam à margem de processos globais ou de procedimentos cotidianos que já se tornaram automáticos.

Essa imersão a campo que abraça a posição do pesquisador enquanto estrangeiro (que está presente na questão de paisagem desde seus primórdios) seria o primeiro passo metodológico para se projetar a paisagem. A ideia seria unir essas duas perspectivas: uma delas seria a percepção de quem projeta e não participa das dinâmicas de um território, apresentando um olhar destituído de significados consolidados; a outra perspectiva consistiria nas concepções de quem habita de fato esse território e que pode não participar de um campo de saber técnico.

Essa questão fica clara nos dois livros de Francesco Careri. Enquanto em "Walkscapes" o autor se concentrava no estudo da ação de caminhar e nas paisagens que tal prática conforma ou revela, em "Caminhar e parar", o próprio título já sinaliza a introdução de uma nova questão: o parar. Depois de tornar visíveis certas paisagens, a abordagem seguinte estaria centrada na vivência dessas paisagens, no sentido de apreender a existência de lógicas que engendram as relações entre indivíduos e entre individuo e espaço. Nesse sentido, já no início do livro, Careri escreve:

Após anos de exploração dos Territórios Atuais, Stalker começa um trabalho de interação com seus habitantes. Passa-se de uma fase de observação e escuta da natureza híbrida dos lugares a uma aceitação da responsabilidade quanto à sua transformação, até a procura de modalidades que impliquem cuidar desses lugares, participando de suas mutações espontâneas (CARERI, 2017, p. 25). 
Essa interação com habitantes parece ser mais clara nos objetos de estudo de Careri, que consistem em comunidades de ciganos e favelas, sendo que se parte do pressuposto de que a coesão dessas comunidades e a organização espacial são articuladas por uma forte identidade. A questão fica mais incerta quando as paisagens estudadas parecem ser genéricas, potencialmente destituídas de qualquer significado ou de qualquer noção de comunidade, situação frequente em cidades médias, por exemplo. Daía importância de uma primeira aproximação com o campo de pesquisa segundo uma postura de observador, no sentido de estar atento a aspectos da paisagem que geralmente não são abarcados pelos discursos técnicos tradicionais.

Partindo da noção central de aproximação entre pesquisador e campo, desdobram-se outras questões que podem orientar o método cartográfico e que explicitam seu caráter complexo e experimental.

Um trabalho que explora detalhadamente o tema da cartografia enquanto método é o conjunto de artigos intitulado "Pistas para o método cartográfico", organizado por Eduardo Passos, Virgínia Kastrup e Liliana da Escóssia (2015). O livro é resultado de discussões promovidas por professores e pesquisadores em seminários realizados no Departamento de Psicologia da Universidade Federal Fluminense e no Instituto de Psicologia da Universidade Federal do Rio de Janeiro. O livro expõe um conjunto de pesquisas e estabelece disposições gerais sobre estratégias metodológicas pautadas pelas reflexões de Deleuze e Guattari, sendo possível identificar congruências com os debates que estão sendo realizados em arquitetura e urbanismo.

O artigo de Johnny Alvarez e Eduardo Passos (2015), intitulado "Cartografar é habitar um território existencial", traz ideias de Deleuze e Guattari para apresentar como se dá o encontro do pesquisador com seu campo, relatando uma pesquisa sobre a prática de capoeira. Habitar um território existencial significa se implicar em um mundo para o acompanhamento de processos, sendo que o território está em constante produção. Os pesquisadores argumentam que o hábito não leva necessariamente ao automatismo, mas elimina generalizações. Por isso a importância em reconhecer a aproximação entre pesquisador e campo segundo uma relação de "saber com" (ALVAREZ; PASSOS, 2015, p. 143), isto é, um processo de aprendizado em conjunto com os eventos e suas singularidades, e não de "saber sobre" (ALVAREZ; PASSOS, 2015, p. 143), que afirma uma dimensão de controle, a partir da qual se busca confirmar ou refutar hipóteses pré-concebidas. "O pesquisador se coloca numa posição 
de atenção ao acontecimento. Ao invés de ir a campo atento ao que se propôs procurar, guiado por toda uma estrutura de perguntas e questões prévias, o aprendiz-cartógrafo se lança no campo numa atenção de espreita" (ALVAREZ; PASSOS, 2015, p. 143).

Essa ideia é aprofundada pelo artigo de Virgínia Kastrup (2015) “O funcionamento da atenção no trabalho do cartógrafo", em que a autora afirma que em uma pesquisa não há coleta, mas produção de dados. Para tanto, é essencial uma postura de atenção capaz de detectar "signos e forças circulantes, ou seja, de pontas do processo em curso" (KASTRUP, 2015, p. 33). Trata-se de definir uma postura participativa do pesquisador que permite a apreensão de lógicas e valores estranhos a um repertório anterior, evitando explicações de fenômenos a partir de concepções externas a eles.

É possível indicar semelhança com o discurso e prática do arquiteto Bernard Lassus, que fala da "atenção flutuante" que está aberta à apreensão das particularidades de um lugar e que podem ser revertidas em diretrizes de projeto. Da mesma forma, essa ideia remete à tática do "tropeçar" de Francesco Careri, necessário ao caminhar que mantém "um olho na rota e outro em tudo aquilo que o tira da rota" (CARERI, 2017, p. 117).

Esse modo de fazer pesquisa está vinculado à noção de "reversão metodológica" (ALVAREZ; PASSOS, 2015). Isso significa que não é uma meta que orienta os procedimentos, mas sim, é o processo de investigação que constrói as metas. Essa questão está explícita no glossário já citado de Francesco Careri, no qual consta o termo metodologia relacionado à dimensão processual.

Também é possível encontrar uma aproximação entre essa questão e a ideia retomada por Careri sobre "perder tempo para ganhar espaço". Ao relatar suas experiências enquanto convidado em universidades (Santiago do Chile, Bogotá, São Paulo), Careri descreve como os procedimentos de conhecimento do território por meio do caminhar possuem, de fato, um ponto final, uma meta. Mas o percurso vai sendo construído de modo a evitar o caminho mais curto. O "errar" é essencial para se conhecer a cidade sem se submeter a intenções de controle, tornando visíveis paisagens que não estavam no roteiro.

O projeto de arquitetura pautado por tais questões adquire uma orientação difusa. As noções de programa 
e diagnóstico de uma área passam a ser questionadas, sendo que as diretrizes e ações projetuais vão sendo construídas de modo conjunto com o processo de conhecimento do lugar. Não se trata mais de diagnosticar os problemas de uma área, para então direcionar intervenções que objetivam sanar esses problemas. As intervenções passam a ser de distintas qualidades: revelar, potencializar, questionar, propor.

Os autores de "Pistas para o método cartográfico" caracterizam este método como pesquisa qualitativa, em contraposição à pesquisa quantitativa, convencionalmente dotada de cientificidade (PASSOS; KASTRUP; ESCÓSSIA, 2015). Trata-se de um modo experimental de se fazer pesquisa, que propõe um questionamento das formas de conhecimento que generalizam e ocultam certos aspectos da realidade. Tais formas de conhecimento, como a estatística, são criticadas por Michel de Certeau ao discorrer sobre as táticas dos praticantes do cotidiano. Segundo o autor,

Ela (a estatística) reproduz o sistema ao qual pertence e deixa fora do seu campo a proliferação das histórias e operações heterogêneas que compõem os patchworks do cotidiano. A força dos seus cálculos se deve à sua capacidade de dividir, mas é precisamente por essa fragmentação analítica que perde aquilo que julga procurar representar (CERTEAU, 2007, p. 46).

Nesse sentido, a pesquisa partiria de uma imersão no cotidiano, esfera da criação, da produção de conhecimento que geralmente não se enquadra nos discursos ordenadores.

O uso da linguagem poética e artística ocupa lugar relevante para pesquisas que lidam com a leitura de paisagens, visto que traz um modo de apresentar informações que extrapolam questões eminentemente técnicas e quantitativas e se volta para particularidades de um lugar, que podem estar vinculadas a uma lógica geral de uma época e que também podem explicitar formas de existência que resistem a uma organização dominante. O esforço de conhecer paisagens indeterminadas associa qualidades percebidas a informações técnicas, para viabilizar o acesso a certos aspectos sutis que conformam o cotidiano urbano.

É importante destacar que trazer a abordagem artística para a pesquisa científica não é algo novo, considerando o contexto posterior à ruptura entre ciência e arte promovida pela ciência positivista. Eric Dardel, em sua geografia desenvolvida na década de 1950, do mesmo modo, já argumentava que a linguagem do poeta 
era mais eficiente para descrever o texto que é a Terra.

Segundo Norberg-Schulz, o "mundo-da-vida" pode ser abordado pela linguagem e pela literatura, sendo que "a poesia é capaz de concretizar as totalidades ${ }^{33}$ que escapam à ciência" (NORBERG-SCHULZ, 2013, p. 445). Esse autor encontra na literatura o que Certeau identificou como insuficiência na representação cartográfica, que reduziria os "enunciados pedestres" ao traçado gráfico, destituído de todas as qualidades que não são necessariamente apreensíveis pela imagem. Nesse sentido, segundo Norberg-Schulz, o poema articula o que é geral ao que é local:

o poema concretiza propriedades básicas da existência. Falo aqui em "concretizar" no sentido de transformar aquilo que é genérico, "visível", isto é, em uma situação local, concreta. Com isso o poema se move numa direção oposta à do pensamento científico, pois, enquanto a ciência parte do "dado", a poesia nos remete às coisas concretas, desvendando os sentidos inerentes ao mundo-da-vida (NORBERG-SCHULZ, 2013, p. 447).

No contexto contemporâneo a congruência entre pesquisa científica e arte é cada vez mais evidente, se considerarmos o campo projetual da arquitetura e urbanismo, indissociável de seu conteúdo criativo. Os processos de leitura de paisagens exigem uma pesquisa poética. "As práticas artísticas (...) transformam a realidade em metáfora para que possamos ampliar a nossa consciência do real. O que antes era impossível de ser pensado, invisível ao pensamento, velado, torna-se, pela metáfora, revelado, possível, evidente" (CARVALHO, 2007, p. 167).

Enquanto Dardel e Norberg-Schulz se concentravam no poema como forma de descrever paisagens e concretizar lugares, o tema é tratado por outros autores por meio de um encadeamento de imagens. Em alguns artistas da Land art fica clara a articulação entre imagem e palavra; Robert Smithson narra paisagens a partir de ferramentas textuais e fotográficas, por exemplo. Destarte, a realização da pesquisa pode se apoiar em dispositivos diversos que cartografam os processos apreendidos, sendo um deles o registro fotográfico. A fotografia, mais do que um registro documental, se coloca como uma ferramenta capaz de reapresentar uma realidade.

33 "Totalidade" é empregada aqui no sentido contrário à fragmentação do mundo promovida pelos conceitos analíticos de uma "ciência que "abstrai" o que é dado para chegar a um conhecimento neutro e "objetivo"”" (NORBERG-SCHULZ, 2013, p. 445). 
Referindo-se ao filósofo francês Roland Barthes, que em 1980 promoveu uma reflexão sobre a dimensão ontológica da fotografia em "A câmara clara", Carvalho (2007) observa que "essa conexão entre o referente (aquilo que está na imagem) e a fotografia, faz com que ela torne notável o que poderia ser ordinário, dando a esse momento um valor e, sobretudo, uma permanência que não teria se não fosse capturada pela lente desse fotógrafo" (CARVALHO, 2007, p. 175).

Essa abordagem da fotografia pode ser observada em outro trabalho de Didi-Huberman (2017) intitulado "Cascas". Através de fotografias, o autor promove uma narrativa sobre sua frequentação do complexo AuschwitzBirkenau, na Polônia. Auschwitz virou museu, transformando um "lugar de barbárie" em "lugar de cultura" (DIDIHUBERMAN, 2017, p. 19) e acrescentando a uma paisagem densamente simbólica, elementos de uma banalidade incongruente: estandes comerciais, placas com informações turísticas. Por meio das imagens apresentadas, DidiHuberman articula questões culturais, políticas e filosóficas à concretude do lugar. Tendo em vista a carga simbólica desse museu e considerando que sua história é de conhecimento geral, o trabalho de Didi-Huberman promove a explicitação de significados de maneira sutil, ao fotografar elementos que a leitura habitual não relacionaria com a história do local, como, por exemplo, cascas do tronco de bétulas que formam um bosque no local, um pássaro que pousou em meio a um emaranhado de arames farpados, etc. Em certo ponto do livro, o autor observa:

A partir desse momento, fotografei praticamente qualquer coisa às cegas. Em primeiro lugar, porque uma espécie de urgência me empurrava para a frente. Depois, porque não me apetecia transformar o lugar numa série de paisagens bem focadas. Por fim, todo e qualquer ajuste me era tolhido, tecnicamente falando, na medida em que a luz opressa desse meio dia, cuja intensidade, ou, caso prefiram, cuja intensidade de chumbo, chegava a ser acentuada pelas nuvens no céu, me impedia de verificar o que quer que fosse no pequeno visor de minha câmera digital (DIDI-HUBERMAN, 2017, p.33).

Da mesma forma, em "Atlas ou a gaia ciência inquieta", reafirma-se a abordagem de Didi-Huberman a respeito do conhecimento construído segundo imagens. O autor afirma que "um atlas de imagens não se limita jamais a ilustrar um saber: constrói-o e, por vezes, chega a desconstruí-Io" (DIDI-HUBERMAN, 2013, p. 172).

Entender a fotografia como parte de uma construção de conhecimento dialoga claramente com as pistas do método cartográfico, que só fazem sentido com operações e ferramentas condizentes com um enfrentamento 
processual de uma questão; daquilo sem um início e um fim, mas em constante produção; de uma realidade rizomática, portanto.

Considerando a pesquisa e projeto da paisagem segundo a perspectiva da cartografia enquanto estratégia metodológica, a fotografia se apresenta como ferramenta promissora capaz de abarcar o caráter complexo e múltiplo do objeto de pesquisa. Além disso, a fotografia permite a captura de momentos efêmeros, prolongando experiências que ocorrem no momento em que se percorre uma paisagem, mas que logo em seguida são esquecidas. Quando se pensa em projeto, tal prolongamento se mostra essencial para que seja possível agenciar significados, condições físicas e percepções diversas.

É importante destacar que não se trata de promover uma leitura sobre a paisagem pautada em questões estritamente subjetivas e individuais. Trata-se, na realidade, de reapresentar a paisagem segundo outras chaves de leitura, que dão abertura a novas interpretações que não estão necessariamente vinculadas às intenções de quem projeta. O projeto da paisagem agencia, portanto, expectativas coletivas e apreensões individuais, estando em constante processo de criação. 
2 - RIOS E CIDADE, ENTRE CONFLITO E CONGRUÊNCIA

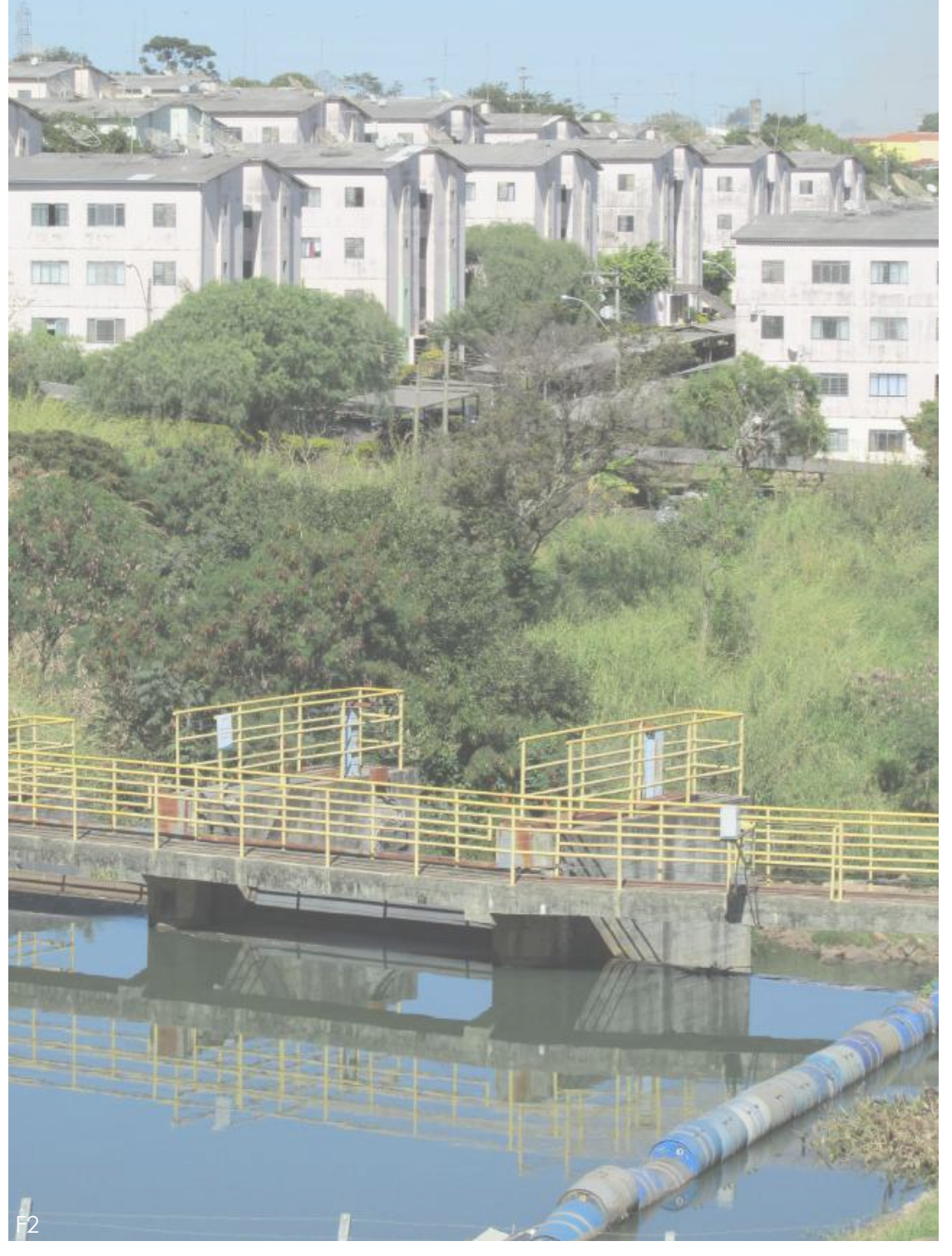




\section{A CONSTRUÇÃO DA RELAÇÃO ENTRE RIOS E CIDADES}

\section{A construção de um conflito}

Estudar a construção da cidade e sua relação com seus rios envolve investigar as dimensões objetivas e subjetivas dessa paisagem. Compreendida como espaço vivido, a paisagem articula a manifestação concreta de processos que transformam o meio às construções simbólicas que se relacionam a tais processos. A produção de significados e percepções interfere na materialização dos processos urbanos e vice-versa. Segundo Berque:

A paisagem é uma marca, pois expressa uma civilização, mas é também uma matriz porque participa dos esquemas de percepção, de concepção e de ação - ou seja, da cultura - que canalizam, em um certo sentido, a relação de uma sociedade com o espaço e com a natureza e, portanto, a paisagem do seu ecúmeno. E assim, sucessivamente, por infinitos laços de co-determinação (BERQUE, 2004, p. 84 - 85).

O tema da relação entre rios e cidades é tratado na coletânea de ensaios organizada por Lúcia Maria de Sá Antunes Costa (2006) intitulada "Rios e paisagens urbanas em cidades brasileiras", que parte do princípio de que "... compreender o rio urbano como paisagem é também dar a ele um valor ambiental e cultural que avança na ideia de uma peça de saneamento e drenagem" (COSTA, 2006, p.12).

Nesse sentido, Jorge Hajime Oseki e Adriano Ricardo Estevam, no artigo intitulado "A fluvialidade em rios paulistas" (2006), interpretam a história da relação entre rio e cidade segundo o conceito de mediância elaborado por Augustin Berque. Os autores entendem a paisagem como impressão dos gestos humanos:

A mediância deve ser considerada em seus três momentos, pois ela é ao mesmo tempo tendência, isto é, o sentido da evolução de um meio físico; sensibilidade comum, ou seja, uma mediação entre sujeito e objeto ou entre indivíduos e grupos, e uma significação subjetiva ou inter-subjetiva. Tais aspectos seriam os principais reveladores de uma paisagem (OSEKI; ESTEVAM, 2006, p. 80).

A frequentação da paisagem que existe na relação entre rios e cidade permite a identificação de diversas qualidades: espaço funcionalizado, claramente identificado, ou relacionado a determinadas concepções do que é 
uma paisagem agradável, "natural"; ou espaço indeterminado, que se coloca à margem dos processos urbanos e não possui valor de paisagem para o senso comum.

Essas duas qualidades estão vinculadas às questões da objetividade e subjetividade da paisagem e da paisagem instituída contraposta à paisagem que resta em relação ao processo de planejamento e projeto e podem ser identificadas através das transformações da relação entre rios e cidades que acompanharam o processo de urbanização das cidades brasileiras de um modo geral. As paisagens que explicitam a relação entre rios e cidades podem ser interpretadas dentro de processos culturais atrelados ao modo como elas foram simultaneamente apreendidas e construídas.

A bibliografia sobre o tema geralmente observa uma alteração que parte de um diálogo entre rios e cidades, que caminha para um conflito (GORSKI, 2010; HERZOG, 2013), no sentido de que uma série de concepções e ações fizeram com que a rede hídrica, em meio urbano, fosse entendida, em um primeiro momento, como presença fundamental e, posteriormente, como um obstáculo a ser superado para o bom funcionamento dos distintos fluxos ou como um problema prejudicial ao cotidiano da população, que deveria ser resolvido e controlado pela técnica.

Segundo esses autores, os rios desempenharam um papel estruturador no cotidiano urbano das cidades pré-industriais, definindo desde a localização dos assentamentos até as diversas atividades que eram desenvolvidas para o funcionamento adequado de um povoado, tais como deslocamento, abastecimento, higienização, extrativismo entre outras (GORSKI, 2010). Algumas dessas funções ainda se mantêm na cidade contemporânea, mas são ressignificadas dentro de novos contextos, caracterizados por novas tecnologias e outras lógicas produtivas.

Conforme observa Michael Hough (1998), com as inovações tecnológicas do século XIX, o abastecimento de água passou a ser feito por meio de canalizações, ocultando definitivamente seus fluxos do cotidiano urbano. O uso dessa técnica foi um dos principais fatores que desencadeou as alterações da relação entre cidade e rios, dando início à construção de infraestruturas que abarcam estritamente o aspecto utilitarista do uso da água nas 
cidades, contribuindo para o gradativo distanciamento entre população urbana e rios. Uma série de técnicas que buscam a eficiência de dinâmicas produtivas suprime do cotidiano a presença de elementos naturais. Os córregos se tornam invisíveis com as obras de canalização, retificação, e ocupação de suas margens. As inovações tecnológicas também facilitaram o acesso à água para determinadas populações, e sua aparente abundância gerou uma ilusão de inesgotabilidade enquanto recurso (SPIRN, 1995).

A invisibilidade do ciclo hidrológico contribuiu para que a população urbana passasse a desconhecer (ou ignorar) seus processos, desencadeando uma série de intervenções que visaram à eficiência do funcionamento do espaço urbano, sobretudo segundo determinações econômicas, independentemente dos processos naturais (SPIRN, 1995; HOUGH, 1998).

Segundo Maria Cecília Gorski (2010), a relação “harmoniosa” entre cidade e rios no Brasil durou apenas até metade do século XX, sendo suprimida pelos crescentes conflitos entre desenvolvimento, sociedade e meio físico. Conforme foram sendo desenvolvidas novas técnicas de construção do espaço, as atividades ligadas ao cotidiano foram sendo distanciadas dos cursos d'água e sua realização passou a configurar relações aparentemente indiretas com esses elementos.

As técnicas convencionais de drenagem urbana, que buscam afastar as águas pluviais das ruas pavimentadas por meio de tubulações subterrâneas que desaguam diretamente nos cursos d'água apresentam até hoje forte resistência a proposições alternativas (SPIRN, 1995). Junto a esse sistema de drenagem, a difusão do automóvel transformou de maneira acentuada as paisagens fluviais, tendo em vista a construção de avenidas marginais que, apesar de ligarem o território em escala regional, fragmentaram-no em escala local (FRANCO, 2005).

As atividades de lazer foram gradativamente afastadas das várzeas dos rios, as quais passaram a ser reconhecidas como espaços ideais para a construção de vias estruturadoras dos fluxos da cidade, visto que consistiam em terras ainda desocupadas em meio ao acelerado processo de urbanização desencadeado a partir da década de 1950 no Brasil. Um dos principais motivos para tanto seriam os baixos valores para sua aquisição e a inexistência, naquela época, de impedimentos legais sobre a ocupação dessas áreas. Este processo caracterizou a 
construção da forma urbana de São Paulo ao longo do século XX, como explicita a tese de Fernando Melo Franco, mas se refere a um modelo que foi disseminado em várias cidades brasileiras de distintos portes.

A impermeabilização do solo, as técnicas de drenagem das águas pluviais, a construção do espaço urbano a partir da estruturação de vias marginais, são fatores que interferiram no ciclo hidrológico natural, aumentando a vazão dos cursos d'água em direção às várzeas, causando processos erosivos e de assoreamento, bem como a crescente poluição dos recursos hídricos. Segundo Hough, isso seria um resultado principalmente da transferência de um problema urbano (o da drenagem de superfícies impermeáveis) para o meio ambiente global, alterando o curso de seus processos naturais.

Essas transformações marcantes na paisagem fluvial, ao mesmo tempo em que eram engendradas por determinados significados associados aos elementos naturais, também contribuíram para a construção de uma nova percepção da população sobre os rios urbanos, dissolvendo vínculos afetivos. Os rios, com suas características naturais transformadas pelas novas tecnologias, deixaram de ser um meio de contato da população urbana com uma "matéria primitiva" que representava a existência de um mundo independente e anterior aos processos urbanos (BARTALINI, 2009). "A relação afetiva e deleitosa, na cotidianidade ou mesmo no contato esporádico com os cursos d'água, não conseguiu resistir às razões utilitárias que os reduziram a peças de uma máquina hidráulica ou usaram suas margens como corredores de circulação" (BARTALINI, 2006, p.90).

Segundo Vladimir Bartalini (2006), enquanto a chamada Rede Hídrica Estrutural exibe um papel utilitário de elemento estruturador de eixos de expansão urbana, em outra escala, a Rede Hídrica Capilar desempenha papel distinto na constituição da forma urbana. Esta última inclui os cursos d’água que já foram sobrepostos pelo tecido urbano, por meio de retificações, tamponamentos e impermeabilização de suas margens; e os cursos d'água de pequeno porte que ainda não foram alcançados pela cidade formal e se encontram em estado de abandono, criando um imaginário de um lugar pleno de irregularidades, da falta de planejamento, do descaso do poder público. Tanto em um caso como em outro, identifica-se um processo consolidado de ocultação e negligência com relação à rede hídrica de menor porte. 
A Rede Hídrica Estrutural seria o foco de obras de grande porte e complexidade, de alcance supostamente sistêmico de acordo à visão de determinados agentes produtores que se colocam em evidência, cujas decisões relacionadas à construção do espaço urbano estariam alinhadas com questões culturais relacionadas a um momento histórico, representado pelas avenidas de fundo de vale. Por sua vez, as intervenções na Rede Hídrica Capilar também se colocam sob a luz dos mesmos valores culturais vigentes, adquirem outros aspectos, e se manifestam sob o domínio da estruturação do território urbano, sendo canalizados ou simplesmente apagados. A Rede Hídrica Capilar passa a ser caracterizada por "cursos d'água sem qualquer expressão na paisagem, seja porque suas ínfimas dimensões os tornam imperceptíveis ao olhar de sobrevoo, seja porque a canalização e o tamponamento os eliminaram por completo da cena urbana". (BARTALINI, 2006, p. 90).

Em linhas gerais, identifica-se, portanto, uma fragmentação dos significados da água e, portanto, dos rios no espaço urbano, apresentando uma dicotomia entre seus sentidos funcionais e estéticos. A apreensão de cursos hídricos segundo aspectos estritamente utilitaristas e de disputa por terras no mercado, transformaramnos em "peças de uma máquina hidráulica" (BARTALINI, 2009) eliminando as possibilidades de fruição de uma paisagem que poderia promover um contato entre homem e mundo, alternativo aos propósitos instrumentais.

Nesse sentido, a noção de paisagem enquanto matriz e mediância discutida por Berque, que apreende o modo como os valores constitutivos de uma mentalidade engendram a paisagem (evice-versa), pode ser associada à argumentação de Hough e Spirn, segundo os quais, é necessária a transformação dos valores da população para que esta retome a consciência dos processos naturais como fundamentais para a vida e promova a construção da cidade em equilíbrio com o meio ambiente natural. Em última instância, a prioridade concedida aos valores no modo como se formula o mundo já era tratada por Merleau-Ponty, segundo o qual, a "intencionalidade" seria um dos temas da fenomenologia que descreve a relação entre o ser humano e o mundo; o ser humano e sua consciência (constituída segundo valores ideológicos, econômicos, religiosos, entre outros) projeta e caminha em direção ao mundo, e não o contrário.

A relação histórica entre cidade e rios não tem um desenvolvimento unidirecional e não se resume exclusivamente à constituição de uma realidade de conflito. A busca por novos modos de conceber a paisagem 
dos rios urbanos pode ser relacionada a dois caminhos: um deles, pertencente, sobretudo, ao campo da ecologia e planejamento, pretende criar instrumentos capazes de reverter a realidade de conflito criando a congruência, isto é, estabelecendo lógicas apoiadas em um desejado equilíbrio entre processos naturais e processos urbanos. O outro caminho mostra afinidades com o campo artístico e de projeto da paisagem e de certa forma abraça a realidade conflituosa e cria estranhamentos que potencialmente dão abertura a novas leituras sobre a relação entre rios e cidade.

\section{Alternativas para planejar e construir a cidade}

A partir da década de 1960, o campo disciplinar da paisagem passou a ser composto por proposições que representavam novos valores a serem inseridos nas dinâmicas de configuração da forma urbana, tendo em vista a busca por um diálogo com as particularidades do meio ambiente natural. Tais elaborações foram reintroduzidas no debate sobre a cidade principalmente pela obra de lan McHarg (1992), "Design with Nature". Reintroduzidas porque, na realidade, a abordagem da construção dos espaços urbanos a partir da dinâmica dos processos naturais já se manifestava no final do século XIX nos projetos de sistemas de parques de Frederick Law Olmsted nos Estados Unidos (SCHENK, 2008; HERZOG, 2010). O que ocorreu a partir da década de 1960 foi uma atualização do tema por autores do século XX, tendo em vista as novas realidades urbanas e as novas tecnologias que influenciaram tanto a construção da cidade, como a análise das características de seu território.

O estudo de McHarg gira em torno da ideia da natureza como processo. Isso denota o caráter cambiante do meio ambiente, encaminhando o pensamento sobre a cidade como espaço igualmente mutável, uma vez que ela consiste em uma adequação das intervenções humanas a uma base natural pré-existente. Sendo assim, a intervenção em uma das partes do sistema natural afeta o todo, pois a natureza é dotada de unicidade (MCHARG, 1992).

Tendo em vista os desequilíbrios evidenciados entre ambiente urbano e natural no contexto do século XX, que resulta de uma série de ações desvinculadas de uma visão abrangente dos processos naturais, McHarg destaca 
a necessidade de uma percepção do mundo através da ecologia. O autor reconhece que é preciso ultrapassar valores representados pela supremacia do homem sobre a natureza, aquele, controlando esta de acordo com seus interesses.

Partindo dessas questões, McHarg discorre sobre uma metodologia de planejamento da cidade, pautada pelo estudo de compatibilidade entre ecossistemas e usos, identificando os espaços livres como elementos essenciais para o funcionamento dos processos naturais no ambiente urbano. A partir da sobreposição de cartografias elaboradas segundo categorias de análise, o autor distingue as diferentes regiões do território segundo suas fragilidades ambientais e potencialidades (por exemplo, a indicação de lugares que dão acesso à visão panorâmica de paisagens) definindo os usos que seriam adequados sem que interferissem nos processos naturais.

Os escritos de lan McHarg contribuíram com a multiplicação de estudos sobre a construção das cidades segundo o viés ecológico, sendo Anne Spirn (1995) e Michael Hough (1998) dois profissionais da arquitetura da paisagem que estão inseridos nessa abordagem, cuja atuação se destaca no último terço do século XX.

Tanto McHarg como Spirn e Hough elaboram uma crítica acerca dos valores tradicionais que atribuem qualidades exclusivamente estéticas à natureza inserida no contexto urbano. A construção da cidade em equilíbrio com o meio ambiente natural, questão investigada por esses autores, deveria ser pautada pela compreensão de um sistema abrangente constituído pelos processos naturais que dão suporte à vida, em diálogo com os processos urbanos.

No livro de Hough, "City form and natural process" e no livro de Spirn "The Granite Garden", o estudo das qualidades potenciais da forma urbana que dialoga com os processos naturais é apresentado por meio de tópicos, cada qual referenciando os principais elementos naturais (fauna, flora, água), sendo que ambos os autores voltam sua atenção para o tema específico da água dentro desse debate. Particularmente, Hough atribui uma dimensão estrutural ao tema com relação aos outros, destacando a água como suporte para a realização de todos os processos naturais. 
Fica evidente nas obras aqui referidas o questionamento sobre a eficácia dos sistemas convencionais de drenagem das águas pluviais, constituídos por galerias subterrâneas e pavimentações impermeáveis. Os desequilíbrios do ciclo hidrológico e suas consequências negativas para o cotidiano urbano são um resultado de tecnologias que buscam solucionar problemas urbanos de modo pontual e imediato, desconsiderando o caráter sistêmico e contínuo dos processos naturais. Trata-se de obras de engenharia que dão a falsa sensação de segurança (SPIRN, 1995) e que transferem para o meio ambiente natural, problemas que surgem com a cidade (HOUGH, 1998).

Hough enfatiza que é necessário o entendimento da natureza na cidade, pois é nela que surgem os problemas ambientais e é a partir dela que estes problemas devem ser solucionados. Não se trata de buscar reconstituir as características originais do meio ambiente natural, o que não seria possível com a presença das modificações operadas pela ação humana, presente em qualquer parte da natureza. A proposta de cidade desses autores está pautada na compatibilização de usos múltiplos, característicos da cidade.

... um retorno a um estado "puramente natural" com ausência absoluta da presença humana é impossível; o importante é que na criação de novas paisagens - uma mescla das naturais e humanas que podem não ter existido antes - se reconheça a interdependência do homem e da natureza nas realidades ecológicas, econômicas e sociais da cidade. (HOUGH, 1998, p. 29) ${ }^{1}$.

A princípio, as forças da natureza não são nem hostis, nem benignas ao homem (SPIRN, 1995). Portanto, para que essa relação entre homem e natureza, entre cidade e rios se mantenha equilibrada, é essencial que seja possível a continuidade dos processos naturais no cotidiano urbano. O modo como os cursos d'água são apropriados pela cidade seria um dos aspectos mais visíveis dessa relação, revelando o conflito ou a congruência.

Se para McHarg os principais empecilhos para a construção da cidade em diálogo com a natureza compreendida enquanto meio físico são as pressões advindas da urbanização e dos mecanismos do mercado

$1 \quad$ No original: "un retorno a un estado "puramente natural" con ausencia absoluta de la presencia humana es impossible; lo importante es que en la creación de nuevos paisajes - una mezcla de los naturales y humanos que pueden no haber existido antes - se reconozcan la interdependencia del hombre y la naturaleza en las realidades ecológicas, económicas y sociales de la ciudad" (HOUGH, 1998, p. 29) 
que a orientam, para Hough, o enfrentamento da questão deve se concentrar essencialmente nos valores que direcionam a vida nas cidades, afirmando que é com a transformação dos valores tradicionais que será possível a construção de um ambiente equilibrado.

McHarg afirmava a necessidade de criação de normas que controlassem interferências nos processos ecológicos a partir da construção do espaço urbano. Mas seus escritos se referem ao contexto norte-americano da década de 1960 sendo que, já nas décadas de 1980 e 1990, assinala-se a existência de um conjunto de leis que buscam promover a proteção de recursos naturais. Tal questão é evidenciada no contexto brasileiro, sendo que atualmente as leis referentes a medidas de conservação do meio ambiente consistem em amplo corpo legal, que, no entanto, se mantém no papel (MARICATO, 2000), indicando a ineficácia da existência de disposições legais sem instrumentos e mentalidades que corroborem sua aplicação.

Hough indica os direcionamentos necessários para a reformulação do desenho urbano, que consiste na alteração de quatro impressões que caracterizam a cidade moderna: a ausência de conexões visuais da cidade com o campo, o uso de parques urbanos exclusivamente para o lazer, a exclusão entre cidade e campo e o emprego elevado de energia nas execuções, funcionamento e manutenções.

Estas alternativas de desenho urbano que são reinseridas no contexto da segunda metade do século XX estão vinculadas a determinadas posturas, sendo uma delas a adoção da ideia de paisagem, segundo o viés ecológico, como conceito norteador das proposições de desenho e planejamento urbano e de intervenções nos espaços da cidade, que são justificadas principalmente pela tentativa de resgatar os processos naturais na cidade.

No contexto contemporâneo, diversos autores abordam o tema teórico e prático da infraestrutura verde (PELLEGRINO et al., 2006; HERZOG e ROSA, 2010; SCHUTZER, 2010), um conjunto de técnicas de desenho e planejamento urbano que têm suas tipologias definidas pela conexão entre as características do sítio natural (ciclo hidrológico, fluxos de biodiversidade, características do relevo e do solo, entre outros fatores) e as dinâmicas e características urbanas, (mobilidade, drenagem de águas pluviais, controle de ilhas de calor, entre outros). Segundo Herzog e Rosa (2010), o conceito de infraestrutura verde se refere a "redes multifuncionais de 
fragmentos permeáveis e vegetados, preferencialmente arborizados (...) interconectados que reestruturam o mosaico da paisagem" (HERZOG e ROSA, 2010, p. 97).

... a ideia de uma infraestrutura verde, agregando corredores verdes urbanos (greenways), alagados construídos (constructed wetlands), reflorestamentos de encostas e ruas verdes, entre outras intervenções de baixo impacto e incorporando melhores práticas de manejo das águas, poderá fornecer importantes contribuições para um desenho ecologicamente mais eficiente da cidade, reforçando o papel crucial dos espaços livres vegetados para uma maior sustentabilidade urbana (PELLEGRINO et al., 2006, p. 59 )

Considerando que tal proposta é centrada no estudo dos espaços livres da cidade, outros autores apresentam uma abordagem complementar, enfatizando o papel estruturador do Sistema de Espaços Livres na constituição da forma urbana, considerados "potenciais realizadores da esfera de vida pública, entendida como a possiblidade do encontro e da diversidade" (MACEDO et al., 2009, p.62). Toda cidade possui um Sistema de Espaços Livres composto por espaços públicos e privados que abrangem desde a escala da calçada, rua, jardins particulares, até os parques públicos ou privados de maior dimensão. Entretanto, são poucos os exemplos de cidades brasileiras com um SEL previamente planejado. Geralmente, o que existe é um conjunto de espaços desarticulados e sem qualificações (MACEDO, 2012).

Tendo em vista as novas abordagens paisagísticas contemporâneas, e considerando o atual contexto conflituoso de inserção de rios e córregos no cotidiano urbano, mostra-se estratégico tomar os espaços livres das cidades de maneira sistêmica, seja do ponto de vista de preservação do meio ambiente, por meio da definição de infraestruturas verdes, seja do ponto de vista da apropriação e das dinâmicas coletivas.

Articulando esses dois enfrentamentos, identifica-se na recente delimitação de áreas de preservação e conservação, de proporção muito maior do que a quantidade de espaços livres qualificados destinados à realização do cotidiano urbano, estoques de espaços livres públicos potencialmente suficientes para atender às demandas por parte da população urbana (MACEDO et al., 2009).

A identificação de possibilidades de reaproximação entre rios e cidades, resgatando a inclusão de elementos e processos naturais no cotidiano urbano por meio da estruturação do Sistema de Espaços Livres, já 
existente nas cidades, atribuindo-Ihes qualidades paisagísticas, mostra-se essencial no contexto contemporâneo da cidade brasileira, caracterizado pela crescente demanda por espaços livres que abriguem diversas funções como lazer, preservação ambiental, circulação, entre outras (MACEDO e SAKATA, 2003).

\section{Releituras de paisagens}

As propostas de alternativas de planejamento e desenho urbano derivadas de noções da ecologia se apoiam na expectativa de que novas tecnologias e políticas públicas seriam capazes de reverter um processo de degradação ambiental, contribuindo para construir cidades sustentáveis e resilientes. No entanto, a aplicação prática desses conceitos se depara com inúmeras barreiras no atual contexto urbano brasileiro, fazendo com que projetos recebam uma série de alterações que interferem nos seus principais objetivos, ou mesmo nem chegam a ser executados. Um exemplo claro nesse contexto é a incompatibilidade entre as disposições legais sobre o meio ambiente e as características reais da cidade. O conflito observável entre as leis e a realidade pode ser compreendido com a identificação das complexidades urbanas relacionadas principalmente ao mercado imobiliário e à lógica financeirizada que incide sobre a configuração da cidade.

A necessidade da transformação dos valores da população, de modo a retomar a consciência dos processos naturais enquanto algo imprescindível para a sobrevivência, defendida por Hough, encontra dificuldades nesse contexto. A incidência das lógicas de mercado em diversas esferas da vida corrobora a continuidade de certos modos de se construir a cidade, pautados em valores estritamente utilitaristas, que buscam a máxima rentabilidade da terra e eficiência dos processos produtivos e de consumo. Discursos que fazem referência à cidade resiliente e sustentável, que geralmente interferem na propriedade privada e vinculam-se à função social da propriedade, frequentemente são subvertidos por essas lógicas, perdendo seu potencial de transformação concreta e se limitando a intervenções superficiais e cosméticas.

Nesse sentido, considera-se essencial pensar o projeto da paisagem em conjunto com o contexto sobre o qual se pretende intervir. O processo de leitura da construção histórica da relação entre rios e cidade e de seus 
testemunhos consiste em uma das frentes para se trabalhar o enfrentamento projetual da relação entre rios e cidade: identificar lógicas predominantes auxilia na elaboração de estratégias exequíveis.

Mas, além de lidar com as regras do jogo, a identificação de lógicas dominantes também pode ser revertida na quebra de leituras habituais. Assim, conhecer práticas sub-reptícias, dos praticantes ordinários da cidade (CERTEAU, 2007), auxilia na construção de um processo criativo integrado ao lugar, que não necessariamente se submeta às lógicas de um grupo hegemônico de agentes.

Em conjunto com a deteç̧ão dos modos de apropriação da cidade pela população, mostra-se promissor reconhecer as manifestações concretas de uma natureza que resiste às transformações humanas e se desenvolve independentemente dela. Nesse sentido, as contribuições de Gilles Clément sobre a Terceira Paisagem são relevantes para promover leituras sobre as paisagens de margem configuradas pelos cursos d'água.

Explicitar as características que são próprias das paisagens banais, dos vazios, pode ser uma estratégia de transformação da relação entre rios e cidades, que desvia do caminho da espetacularização, dos projetos descolados das peculiaridades de um lugar, que terminam por se desdobrar em processos de especulação imobiliária, gentrificação e aprofundamento da segregação socioespacial. A intervenção que se volta para as singularidades de cada paisagem pretende passar do conflito à congruência, sendo que, no contexto contemporâneo, isso não significa retornar a um estado natural da superfície terrestre, mas de retomar a consciência da existência de processos incompatíveis com a fixidez prevista por certos modos funcionalistas de construir a cidade.

Desvincular a apreensão e concepção da paisagem de intenções puramente funcionalistas é o pressuposto para se pensar o projeto da paisagem no contexto contemporâneo. Dar abertura para que as multiplicidades do urbano articulado às particularidades de uma base pré-existente se expressem na paisagem se torna um dos temas nevrálgicos do projeto e intervenção na paisagem.

Assim, apesar de necessária, a abordagem ecológica da paisagem não é a única pauta em relação ao contexto de conflito representativo da relação entre rios e cidade. No que diz respeito ao projeto da paisagem, existem outros enfrentamentos da questão que, mais do que pretenderem a transformação concreta e sistêmica 
de uma realidade, buscam provocar uma reflexão acerca da realidade como ela é, na escala cotidiana, sem a pretensão de preencher todos os vazios que restam ao longo do processo de planejamento e projeto (CERTEAU, 2007; CARERI, 2013).

Longe de ser uma visão romântica, puramente estética, tal abordagem seria uma forma de lidar com situações em que a reversão a um estado natural ou minimamente recuperado seja improvável. Trata-se de reacender e criar significados, provocar novas leituras, que auxiliem no resgate da consciência coletiva sobre a existência de uma base natural que, apesar de suprimida do cotidiano, mantém-se presente, não apenas em seu aspecto destrutivo (nas ocorrências de enchentes), mas de maneiras sutis, pouco visíveis entre os significados historicamente construídos com relação ao papel de controle da natureza pela técnica.

Apesar das tentativas insistentes em ocultar ou controlar a rede hídrica presente no território urbano, a paisagem apresenta a persistência desses elementos naturais em não serem fixados e esquecidos em meio ao crescimento da cidade. A sobreposição de processos que moldam a forma do espaço urbano explicita uma série de testemunhos que resgatam a presença de processos naturais existentes na cidade (BARTALINI, 2006). Tais testemunhos podem ser uma rua sinuosa em meio a uma malha ortogonal; um som persistente de água corrente em um bueiro; a súbita declividade de uma área.

Ao longo da construção da forma urbana, ocorre o acúmulo de processos na paisagem, que explicitam a presença insistente de marcas representativas dos mecanismos naturais, as quais possibilitariam a retomada de relações sensíveis com a base material original do ambiente no qual atua o ser humano. "Devidamente alinhavadas, essas marcas materiais podem recontar a "história" dos córregos e torna-la concretamente disponível, ou seja, passível de ser lida e fruída nas práticas diárias que se dão sobre o espaço” (BARTALINI, 2006, p.91).

Assim como Francesco Careri e James Corner, Bartalini destaca o papel central que a arte pode desempenhar no projeto em Arquitetura da Paisagem. Também menciona o campo da Land Art como promissor para se pensar intervenções em contextos complexos cuja solução não está necessariamente na realização de grandes obras que reestruturam o espaço, mas em pequenas intervenções que desestabilizam a leitura habitual de um lugar. A 
isso se soma a noção de intervenção mínima de Lassus, que concebe o projeto da paisagem, mais do que uma transformação concreta, uma explicitação do que já existe e que passa despercebido nos ritmos cotidianos.

Nesse sentido, a intervenção na paisagem deixa de ser uma "solução" determinada por ações que respondem a um diagnóstico, e passa a construir novos significados a partir dos processos de leitura, reapresentando o que já está lá.

Conforme aponta James Corner, ao discorrer sobre a relação entre ecologia e processo criativo, o projeto arquitetônico não se resume a propósitos corretivos ou de restauração de uma condição primordial. Trata-se na verdade, da invenção de novas formas (CORNER, 1997).

Esse modo de lidar com a paisagem enfrenta o desafio de subverter as concepções hegemônicas sobre espaço público e privado, sobre a necessidade constante de tornar o tempo produtivo, que subtraem do cotidiano, momentos para se fruir uma paisagem.

Nesse sentido, cumpre retomar o papel central do caminhar no processo de conhecimento e intervenção no território. As grandes obras de engenharia pautadas na lógica do automóvel e no controle dos processos naturais pela técnica promoveram desenhos da cidade que partiram de uma visão de sobrevoo. O desejo de abarcar uma grande parcela do território implica desconsiderar especificidades de cada local, apreensíveis somente pelo olhar de quem vive essas paisagens, geralmente ignoradas pelos técnicos que a observam por meio das tradicionais representações quantitativas.

Um desdobramento desse modo de conceber o espaço relaciona-se com as questões trazidas por Eric Dardel, vinculadas à fenomenologia, que critica o discurso científico que abstrai o mundo vivido. Nesse sentido, é como se a visão de sobrevoo que orienta a construção da cidade a convertesse em um mapa com coordenadas cartesianas, cuja vida ocorresse somente em determinados pontos, sendo o intervalo de deslocamento entre esses pontos um momento indeterminado, em que nada acontece, em que se perde tempo.

De forma paralela, é inevitável que a abordagem ecológica que pretende lidar com uma visão sistêmica 
da paisagem deixe de abarcar algumas especificidades, estando focada principalmente em propósitos de planejamento urbano. Ao trabalhar com tipologias (por exemplo, tipologias de infraestrutura verde) e grandes porções de território, a abordagem ecológica tem o mérito de conceber a paisagem como a articulação entre processos naturais e urbanos. Trata-se de um esforço necessário para se dissolver uma concepção dominante sobre como construir a cidade de maneira mais "eficiente". Entretanto, considerando as complexidades do projeto da paisagem exploradas até aqui, parece imprescindível a complementação da abordagem ecológica pela observação das paisagens cotidianas relacionadas ao mundo vivido.

Assim, a proposição desse trabalho está ancorada em uma aproximação com o território estudado, visando um contato direto com suas paisagens, de modo a agenciar os múltiplos processos que contribuem para a sua constituição e que não estão relacionados a aspectos estritamente funcionais. Trata-se de conceber uma cartografia dessas paisagens, no sentido atribuído à palavra por Deleuze e Guattari e pelos autores que abordam o Método Cartográfico, cujo processo de elaboração é indissociável do caminhar como prática estética (CARERI, 2013). Seria através do caminhar, do processo de frequentação dessas paisagens, que seria possível promover a mediação entre diretrizes gerais de planejamento urbano e qualidades pontuais de cada lugar.

O caminhar pela cidade permite conhecer a relação entre rio e cidade de fato, isto é, enquanto fenômeno. O que pode ser visto pela visão de sobrevoo como avenidas marginais estruturantes da cidade ou massas arbóreas que resguardam um curso d’água, é convertido, pelo caminhar, em paisagens plurais apreensíveis apenas com a aproximação e o contato direto com o mundo (MERLEAU-PONTY, 1994). 


\section{SÃO CARLOS E MONJOLINHO}

\section{Caracterização de São Carlos}

São Carlos é uma cidade de médio porte do interior do Estado de São Paulo, atualmente com 249.415 habitantes, distando 236 quilômetros da capital (IBGE, 2018). O território do município se localiza sobre o divisor de águas das bacias hidrográficas Tietê-Jacaré e Mogi Guaçu e apresenta altitudes que variam de 700 a 900 metros. Alguns elementos que compõem seu território se destacam do ponto de vista ambiental, como a Área de Preservação Corumbataí, a Estação Ecológica e uma área de recarga do Aquífero Guarani na região sul (SCHENK; PERES, 2014).

O território do município é caracterizado por uma rica rede hídrica composta por cursos d’água pouco caudalosos. O atual perímetro urbano de São Carlos é envolvido quase completamente pela bacia hidrográfica do Córrego Monjolinho, o qual tem suas nascentes localizadas na região leste da cidade, desaguando no Rio Jacaré Guaçu.

Os cursos d'água que foram sendo envolvidos pelas ocupações urbanas se colocaram em contextos distintos do processo de urbanização de São Carlos. Cada período do desenvolvimento da cidade explicitou algumas lógicas predominantes, concretamente apreensíveis nos cursos d’água inseridos e articulados a esse processo.

Pode-se dizer que, ao longo do tempo, estabeleceu-se uma relação conflituosa entre os rios e a cidade de São Carlos, visto que seu processo de urbanização apresentou uma sequência de ações que buscaram controlar os processos naturais por meio da técnica, tornando-os invisíveis no cotidiano urbano. A interpretação dos cursos d'água se pautou principalmente por aspectos negativos de sua presença: a ocorrência de enchentes, mau cheiro, interrupção das vias de tráfego, os quais não são de fato características intrínsecas aos rios e córregos, mas que 
se estabelecem conforme se constrói o espaço urbano de maneira incongruente com os processos naturais. Com base nessa leitura historicamente constituída, consolidaram-se percepções que, ao mesmo tempo em que foram resultado de lógicas de construção da cidade, contribuíram para a continuidade e desdobramento de determinados valores que consideram os rios como empecilhos ao desenvolvimento urbano, como espaços de margem (NOGUÉ, 2008).

Mesmo que a construção de um conflito seja o aspecto predominante da relação entre rios e cidade ao longo do tempo em São Carlos, pode ser identificada uma série de ações e discursos que intentam interromper esse processo e transformar o modo como a cidade é construída, segundo questões socioambientais. Tratam-se de modos de pensar que acompanham a mentalidade que foi sendo formulada ao longo do século XX no contexto global, segundo a qual os procedimentos convencionais de construção do espaço urbano, caracterizados pela impermeabilização excessiva do solo e do confinamento subterrâneo das águas, não são mais considerados eficientes a partir do momento em que ocupam primeiro plano o fator ambiental e a busca pelo funcionamento adequado dos ecossistemas.

Seja pelo conflito ou pela busca pela congruência entre cidade e natureza, os córregos exerceram influências relevantes na conformação da cidade e das paisagens que conformam o cotidiano. Neste momento, este trabalho tenta explicitar o modo como as relações socioeconômicas e culturais foram expressas na materialização do espaço urbano de São Carlos, tendo em vista a confrontação entre as práticas urbanas e as características naturais do território estudado, especificamente sua rede hídrica.

A descrição do processo de construção da forma urbana de São Carlos orientado pela identificação de relações entre cidade e córregos estabelece uma base referencial para o estudo dos modos contemporâneos de apropriação dos cursos d'água no cotidiano da cidade e para a identificação de lugares potenciais para a explicitação de paisagens. 

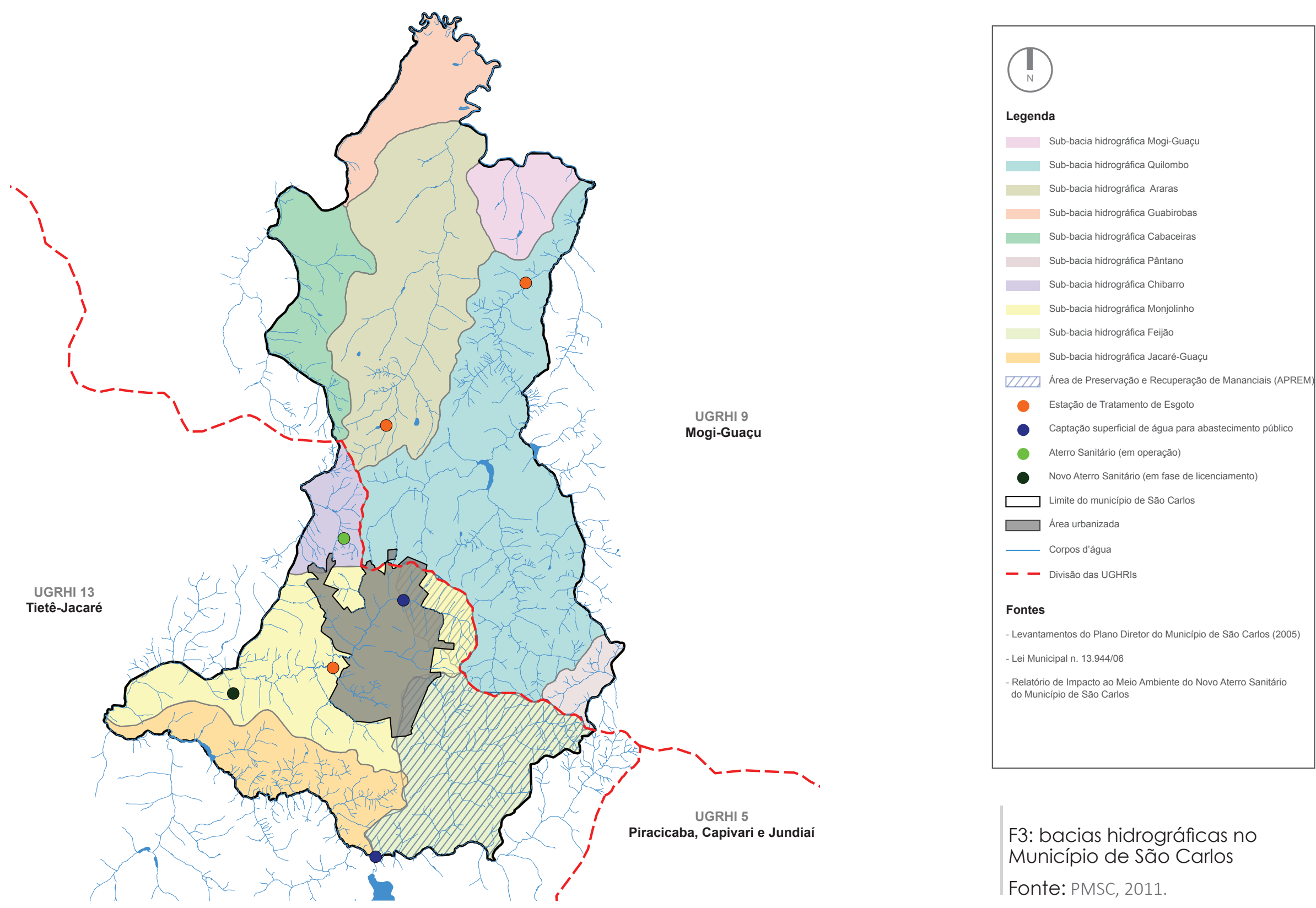

F3: bacias hidrográficas no Município de São Carlos Fonte: PMSC, 2011. 
F4: principais córregos da bacia hidrográfica do córrego Monjolinho.

Fonte: elaborado a partir de carta de hidrografia do IBGE e imagem do Google Earth.

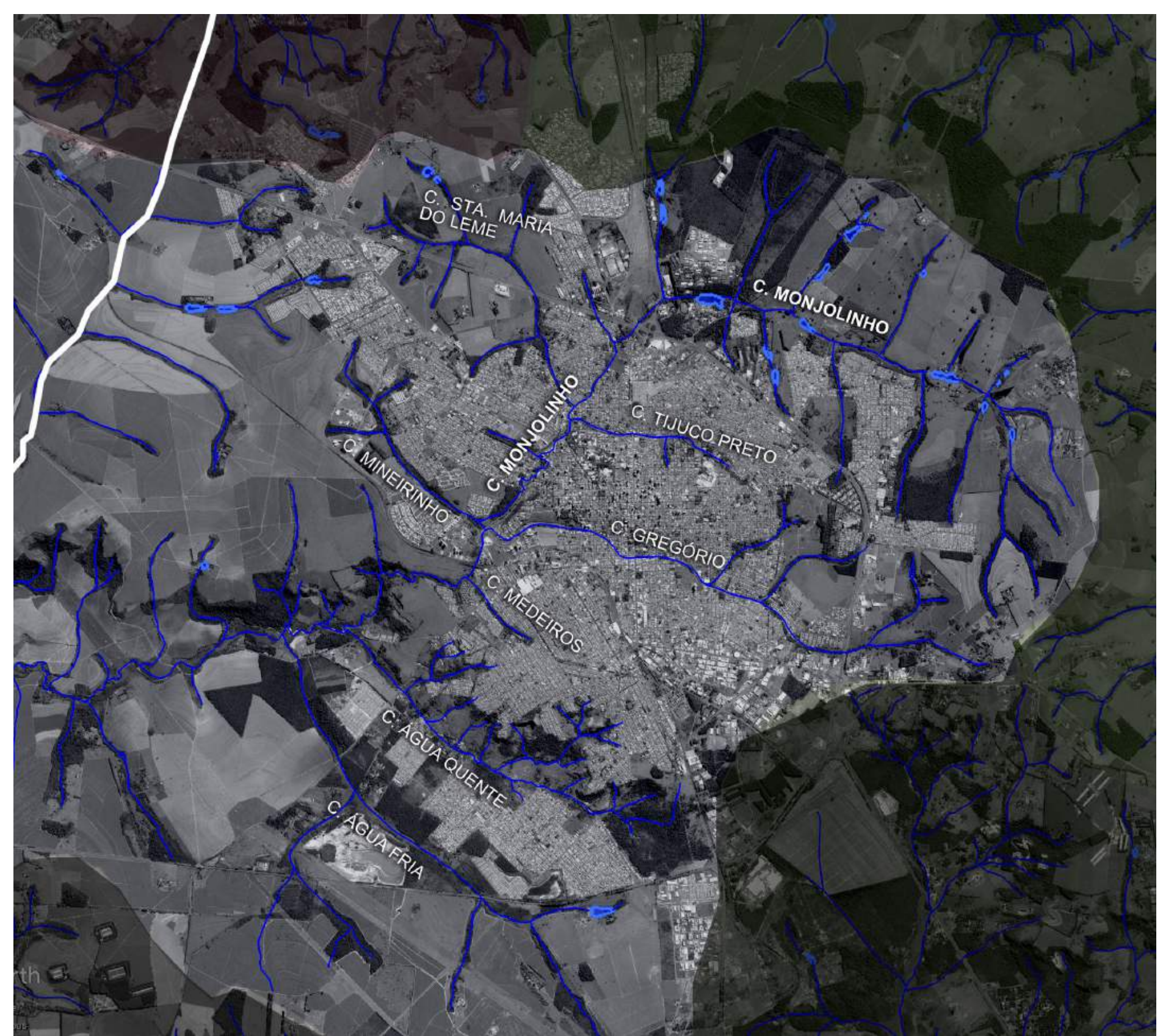




\section{A urbanização de São Carlos: do café à indústria}

A relação de dependência entre cursos d'água e cidade já pode ser indicada logo no início da constituição do núcleo que daria origem à cidade de São Carlos. Assim como várias outras cidades brasileiras, as primeiras ocupações do território estudado foram motivadas, dentre outros fatores, pela presença de um curso d’água.

O núcleo urbano que deu origem à cidade de São Carlos foi constituído a partir do encontro entre o chamado Picadão de Cuiabá, caminho que conectava o litoral às atividades mineradoras de Goiás, e o córrego Gregório. Esse caminho incluiu a região de Araraquara em uma rota comercial, o que motivou o surgimento de diversas vilas, dentre elas, a de São Carlos. Esse processo inicial estava inserido na estratégia de incentivo da coroa portuguesa em estabelecer atividades lucrativas para a criação de vilas e povoados, no contexto de disputa por áreas das colônias entre Portugal e Espanha (LIMA, 2008)

O Picadão de Cuiabá atravessava os córregos Gregório e Monjolinho, sendo que no encontro com o primeiro se estabeleceram aglomerações que efetuavam trocas comerciais com os viajantes que passavam pelo local. O potencial de constituição de uma cidade a partir dessas aglomerações foi impulsionado com a produção cafeeira, que motivou interesses comerciais na região por parte dos proprietários de terras. Nesse momento, iniciaram-se os pedidos de sesmarias ${ }^{2}$, que dariam origem às vilas (BISINOTTO, 1988).

O sistema de doação de sesmarias foi suspenso com a independência do Brasil em 1822 e a obtenção de terras prescindiu de regulamentação até a instituição da Lei de Terras em 1850, quando a terra adquiriu o estatuto de propriedade privada, a ser comercializada a partir da compra e venda. Esta nova disposição legal teve repercussões nos modos de parcelamento e ocupação da terra e tornou frequente o desenho em tabuleiro de xadrez, que deixou de ser exceção no Brasil no século XIX (MARX, 1991). "A um certo procedimento de distribuir a terra, de partilha-la e de concede-la correspondeu um certo delineamento de nossa paisagem típica. À geografia,

2 O território de São Carlos foi constituído a partir de três sesmarias: a Sesmaria do Pinhal, demarcada em 1786 por Carlos Bartolomeu Botelho, à qual foram adicionadas duas glebas demarcadas em 1831 por Antônio Carlos de Arruda Botelho; a Sesmaria do Monjolinho, demarcada em 1811 por João Alves de Oliveira; e a Sesmaria do Quilombo, demarcada em 1812 pelo Padre Manoel Joaquim do Amaral Gurgel (BORTOLUCCI, 1991). 
ao quadro natural encontrado, superpôs-se uma outra realidade, humana, precisamente fundiária" (MARX, 1991, p. 47).

No núcleo que deu origem à cidade de São Carlos, a ocupação motivada pela produção cafeeira foi estruturada pela abertura de ruas a partir do Picadão de Cuiabá, que seguiram o modelo iluminista adotado por Portugal no período, determinando o desenho de uma grelha ortogonal (BISINOTTO, 1988).

Em 1857 foi inaugurada a capela e criado o distrito da Paz de São Carlos do Pinhal, subordinado à câmara de Araraquara. Em 1858 São Carlos tornou-se freguesia e em 1865 foi elevado a vila, adquirindo autonomia política (LIMA, 2008).

O espaço urbano foi adquirindo relevância na medida em que o excedente do capital da produção cafeeira foi sendo aplicado em infraestruturas urbanas e serviços: a rede de iluminação pública teve seu funcionamento iniciado em 1894 (DEVESCOVI, 1987), sendo que em 1893 foi construída a usina hidrelétrica Monjolinho I, primeira do Estado de São Paulo, cujo funcionamento foi assumido pela Companhia Paulista de Eletricidade em 1907, com a construção da usina Monjolinho II no mesmo local (PROJETO ELETROMEMÓRIA, n.d.); em 1895 foram implantadas três linhas do bonde, que atravessavam o córrego Gregório em três pontos, cujo funcionamento ocorreu entre os anos de 1915 e 1962 (DEVESCOVI, 1987; DONOSO, 2011); em 1890 foram construídas redes de abastecimento de água e coleta de esgoto por meio de contratos de serviços públicos e privados; em 1890 foi criada a primeira Casa Bancária e em 1892 foram criados o Banco União de São Carlos e o Banco de São Carlos (LIMA, 2008). Esse conjunto de investimentos atraiu a população rural para a cidade, inclusive os fazendeiros de café, que, se num primeiro momento frequentavam a cidade apenas para tratar de negócios e lazer, passaram a fixar suas residências no núcleo urbano (DEVESCOVI, 1987).

Conforme apontam diversos estudos históricos sobre esse período, com a abolição da escravatura grande contingente de imigrantes estrangeiros se inseriram na produção cafeeira. A presença marcante de imigrantes em São Carlos foi um dos fatores que motivaram o surgimento da indústria no final do século XIX, sendo que algumas fábricas foram criadas por integrantes dessa população (FEITOSA, 2015; DONOSO, 2011). 
Os limites urbanos da cidade se contiveram na microbacia do córrego Gregório até o desenvolvimento da produção industrial, estimulada precocemente a partir da inauguração da ferrovia em 1883 e, posteriormente, pela crise do café no início do século XX.

O intuito original da construção da ferrovia foi facilitar a circulação de mão de obra e produtos vinculados à economia cafeeira. Este elemento caracterizou-se como um novo eixo de atração de atividades urbanas, onde foram concentradas as habitações da classe operária constituída com a ascensão da atividade industrial, enquanto que no centro, próximo à catedral, concentrava-se a elite oligárquica do café e a burguesia emergente, vinculada à produção industrial e à atividade comercial (DEVESCOVI, 1987).

Construída a meia encosta, a linha férrea parece ter impulsionado o adensamento de edificações nas margens do córrego Gregório. Como a ferrovia não foi construída nos fundos de vale, essas áreas se mantiveram livres para a construção de edificações, e se configurou como uma barreira a ser transposta para o alcance da nova área industrial da cidade, nas proximidades da estação ferroviária na margem esquerda do córrego. Curso d'água e ferrovia teriam influenciado, do ponto de vista concreto, a constituição inicial da forma urbana e o princípio de uma segregação socioespacial de seu território. Seria possível dizer que o córrego contribuiu com a delimitação de dois tipos de ocupação iniciais, engendradas pelo contexto econômico do período: em cotas mais elevadas e distantes de áreas afetadas pelas cheias, na margem direita, foram construídos os casarões da elite cafeeira, as primeiras praças (jardins públicos), compondo o entorno da catedral; em áreas mais próximas das margens do córrego e atravessando-o para sua margem esquerda, predominavam o comércio popular e as fábricas e residências da classe operária, atraídas pela instalação da ferrovia.

Até 1929 o controle das terras era feito pela Câmara formada pela elite local, por meio de uma sequência de Códigos de Posturas, que determinavam a forma da doação de datas, medidas de terrenos, largura das vias e perímetro urbano. Com o Código de 1929 foi estabelecida uma nova estrutura administrativa que colocou em evidência o poder executivo, atribuindo o controle do solo urbano ao prefeito. Este código passou a definir parâmetros de uso e ocupação do solo, proibindo algumas atividades dentro da cidade, e abandonou a exigência da continuidade do traçado das vias em quadrícula (LIMA, 2008). 
Nesta primeira etapa do crescimento urbano de São Carlos, já se notavam relações conflituosas entre cidade e rede hídrica. A proximidade entre a malha urbana com os córregos Gregório e Simeão já resultava em problemas de enchente e poluição, registrados desde, pelo menos, o final do século XIX, como noticia o jornal local da época, "O Correio de São Carlos": "O encanamento que leva água para os moradores do bairro da Estação rompeu-se hontem, à Rua Visconde do Pinhal, esquina da Rua Riachuelo por causa da grande enchente do córrego que atravessa a cidade nesse ponto" (O Correio de São Carlos, 24 de novembro de 1899) ${ }^{3}$.

Com o avanço da urbanização, em conjunto com o desenvolvimento industrial, que, segundo Devescovi (1987) passou a se desvincular da produção cafeeira, diversificando as atividades, a cidade começou a ultrapassar os limites da microbacia do córrego Gregório e a implantação dos novos loteamentos deu início a um desenho descontínuo com relação ao núcleo original da cidade. Segundo Lima, "o traçado ortogonal, com quadras de faces iguais, era menos lucrativo, economicamente pouco eficiente, por acomodar um número relativamente pequeno de lotes em relação ao tamanho da gleba loteada" (LIMA, 2008, p. 119).

Gradativamente, a indústria substituiu o café como principal atividade econômica, o que também concedeu à área urbana uma independência produtiva com relação à área rural, principalmente a partir da década de 1940 (DEVESCOVI, 1987).

De modo geral, os arruamentos constituídos neste período seguiram um padrão em quadrícula que se sobrepôs às características originais do sítio natural, isto é, relevo e presença de córregos. Tendo suas margens ocupadas desde as origens da cidade de São Carlos, o córrego Gregório pode ser visto como um testemunho da sobreposição de tempos e ações que tentaram suprimir esse curso d'água do cotidiano urbano. Mesmo que tenha participado, enquanto elemento de atração, do momento em que surgiram as primeiras ocupações que dariam origem à cidade de São Carlos, desde o início a cidade foi construída dando as costas para o córrego e o identificando como um problema que deveria ser resolvido para a expansão urbana. 

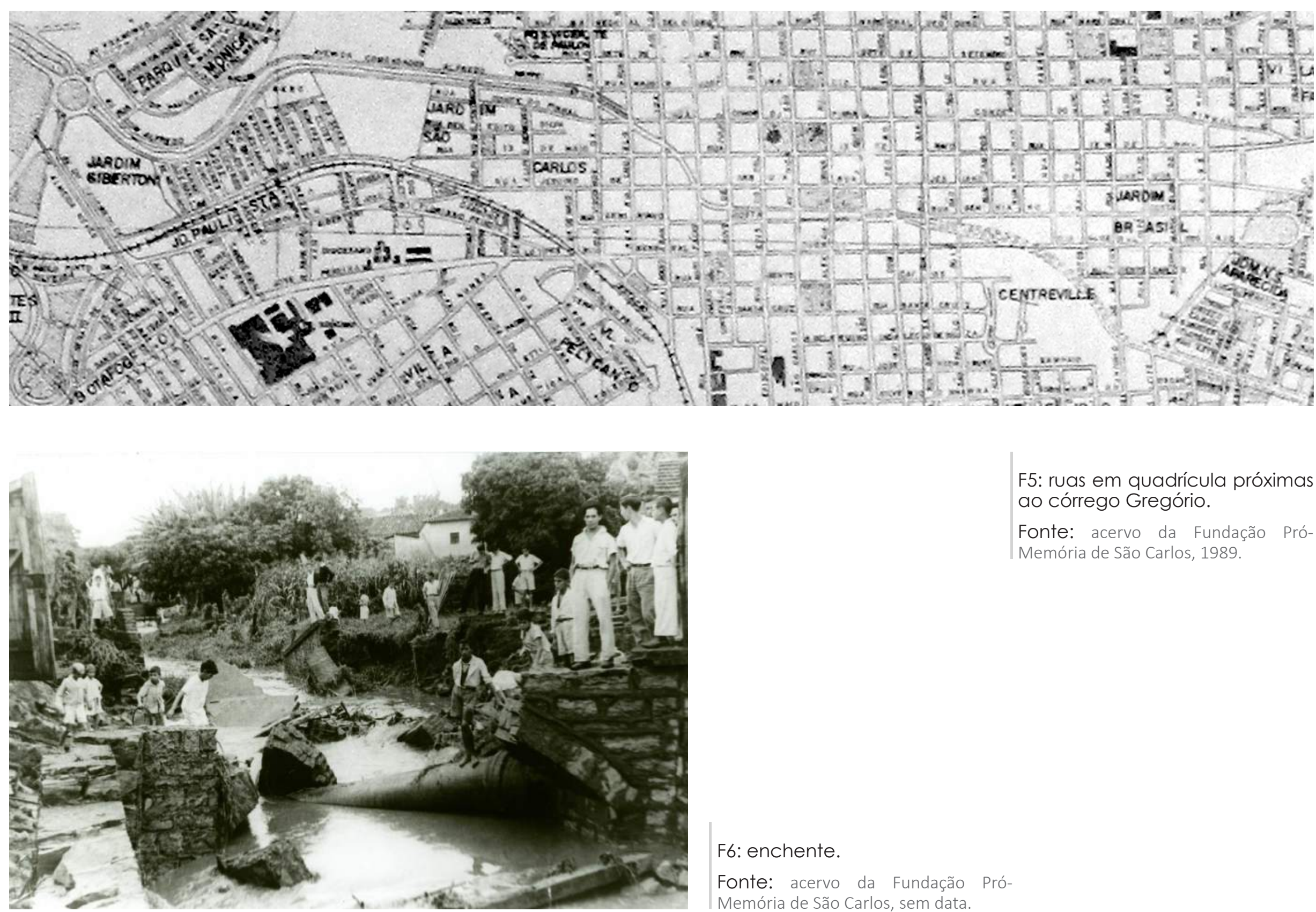

5: ruas em quadrícula próximas ao córrego Gregório.

Fonte: acervo da Fundação Pró-

Memória de São Carlos, 1989. 


\section{Aceleração da urbanização e industrialização de São Carlos}

A sequência de governos estabelecidos desde os anos $1930^{4}$ no Brasil se caracterizam por medidas de incentivo à industrialização, que aceleraram a urbanização do país. Em São Carlos, a década de 1930 foi marcada pela instabilidade de oito administrações diferentes em oito anos e pelo aumento de recursos e autonomia municipais devido à primeira reforma constitucional que reduziu o poder do Estado. Essa autonomia dos municípios foi interrompida no período de 1938 a 1945, referente à atuação de interventores do Estado vinculados à criação do Departamento Administrativo do Serviço Público. Em 1946, com a nova constituição, retomou-se a autonomia dos municípios e em 1948, com a ocorrência de eleições livres em São Carlos, colocou-se fim à hegemonia da elite agrária, dando espaço para a nova elite industrial e comercial (DEVESCOVI, 1987; LIMA, 2008).

Na década de 1940, diante dos parâmetros urbanos flexíveis vagamente determinados pelas leis do período, ocorreram diversas alterações no perímetro urbano de São Carlos. Como aponta Renata Priore Lima, "a legislação veio a reboque do processo de expansão, regularizando a ocupação urbana da área rural" (LIMA, 2008, p. 129).

A partir do final da década de 1940 ocorreu o espraiamento da cidade, tendo em vista a difusão do uso do automóvel e o controle pouco rígido da implantação de loteamentos a partir do parcelamento de propriedades privadas (PERES, 2012). O novo elemento de atração de ocupação urbana foi a Rodovia Washington Luís, construída entre 1953 e 1955 para facilitar a conexão de São Carlos à Rodovia Anhanguera. Ocorreu então a ocupação de regiões mais distantes, como a microbacia do córrego Tijuco Preto e regiões próximas às margens do córrego Monjolinho.

O mercado imobiliário passou por reestruturação, tornando-se cada vez mais dinâmico e promissor, incorporando comerciantes e industriais locais, os quais se tornaram os principais investidores no negócio de compra e venda de lotes nesse período. Eles contavam com o apoio direto da Prefeitura Municipal na realização

4 Getúlio Vargas, 1930 - 1945 e 1951 - 1954; Eurico Gaspar Dutra, 1945 - 1950; Café Filho 1954 - 1955; Juscelino Kubitschek, $1956-1961$. 
dos loteamentos (LIMA, 2008, p. 108).

As décadas de 1960 e 1970, no contexto estabelecido a partir do golpe militar de 1964, são marcadas, por um lado, por avanços do ponto de vista econômico ${ }^{5}$, embora esse crescimento tenha sido acompanhado pela exacerbação da desigualdade social ${ }^{6}$, que teve rebatimentos na constituição do espaço urbano.

A migração cada vez mais acentuada da população rural para as cidades ocorreu segundo um processo descontrolado de urbanização. A expansão das cidades foi constituída principalmente pelo crescimento precário de periferias sem a infraestrutura e os equipamentos necessários para atender às necessidades desse novo contingente populacional.

Outro fator que influenciou o desenvolvimento da cidade a partir da década de 1960 foi o processo de institucionalização do planejamento urbano em São Carlos. Em 1962 foi elaborado um Plano Diretor, que contou com a participação do Escritório Técnico do Plano Diretor de São Carlos, criado em 1960, e do Centro de Estudos e Pesquisas Urbanísticas ${ }^{7}$. Foi elaborado um diagnóstico do município de São Carlos, que constatou o quadro de irregularidade de loteamentos recentes, caracterizados pela ausência de áreas livres e verdes, existência de lotes vagos, infraestrutura precária, descontinuidade do sistema viário e a degradação de mananciais do município (LIMA, 2008; PERES, 2012). Dentre as diretrizes estabelecidas, foi definida uma proposta de ampliação do sistema de recreio, a partir da

...criação de parques e jardins ao longo das marginais, formação de bosques nos fundos de vale, implantação de um grande lago artificial, construção de praças de esportes, formação de cinturão verde de chácaras entre

$5 \quad$ Crescimento do PIB para 11,2\% em 1969 e 13\% em 1973; baixos índices de inflação em torno de 18\% ao ano; crescimento da indústria, principalmente dos setores automobilístico, produtos químicos e material elétrico; crescimento do setor da construção civil a partir dos recursos disponibilizados pelo Banco Nacional de Habitação; condições tributárias favoráveis à exportação, dentre outros aspectos (LIMA, 2008).

6 Abandono de políticas sociais e queda dos indicadores de saúde, educação e habitação; acentuação da desigual distribuição de renda e redução do poder aquisitivo das classes populares. O próprio desenvolvimento econômico encontrou alguns limites com a dependência de produtos importados e o aumento da dívida externa (LIMA, 2008).

$7 \quad$ O CPEU foi criado em 1955 na Faculdade de Arquitetura e Urbanismo da Universidade de São Paulo, com direção de Anhaia Mello, no âmbito de constituição da estrutura de planejamento urbano no Estado de São Paulo (LIMA, 2008, p.182). 
a área urbana e a Rodovia Washington Luís e melhora no aproveitamento das áreas livres dos loteamentos implantados e dos futuros parcelamentos. (SÃO CARLOS, Plano Diretor do Município de São Carlos, 1962 apud LIMA, 2008, p. 190).

Este plano não foi aprovado e resultou em algumas disposições legais como a lei de loteamentos (Lei ํo 4411/1962), as leis que determinaram a Zona Industrial (Lei no 5329/1966, Lei no 6871/1971, Lei no 7037/1972) e a lei de habitação (Lei no 4666/1963) (LIMA, 2008).

Os bondes elétricos, que funcionavam desde 1914, foram substituídos pela utilização de ônibus em 1962, que, em conjunto com a difusão do automóvel, incentivou o investimento em obras de infraestrutura viária. No final da década de 1960, começaram a ser construídas as avenidas em fundos de vale, possibilitadas por um conjunto de fatores: a crescente especulação imobiliária, as disposições legais pouco restritivas e a difusão do automóvel.

Notícias do jornal "A Folha" de 1968 mostram que, nesse período, o córrego Gregório ainda era identificado como obstáculo aos processos urbanos, mas passou a ocupar lugar de destaque nas manchetes, com a execução das obras de canalização de seu curso, identificadas como ações que buscavam trazer o progresso à cidade.

F7: matéria do jornal A Folha de $01 / 09 / 1968$.

Fonte: acervo da Fundação PróMemória de São Carlos, 1968.

\section{Uma Avenida que se chama Progresso}

Agora São Carlos está se aprimorando ainda mais no terreno do urbanismo. A Avenida que se acha em construção e que margeia o córrego "Gregório" será, quando terminada, uma das mais bonitas e funcionais do interior.

\section{Man cheiro do Ria Gregório está causando intoxicaçäo}

F8: matéria do jornal A Folha de $20 / 04 / 1968$

Fonte: acervo da Fundação PróMemória de São Carlos, 1968

\section{DOV terminnul canalizacāa do Córrẹo óreyório}

As obras de canalizacão do Córrego do Gregório, no trecho situado entre as Ruas Dna. Alexandrina e Avenida São Carlos, chegaram a seu término, ficando assim completado o conjunto de obras que inclui Mercado Municipal, Praça Santos Dumont e retificação do Córrego. Esta obra, realizada pela Diretoria de Obras e Viacão da Prefeitura Municipal, vem resolv er definitivamente o problema que periòdicamente fazia do velho Mercado um verdadeiro lamaçal, ou seja, o problema crucial e antigo das enchentes. Com a retificação do Córrego são remotas as possibilidades de que 0 atual Mercado venha a ser inundado, além de que a retificação do Córrego não ficou restrita a apenas esta parte de seu percurso, havendo autorizacão para construção de no va ponte no cruzamento das Ruas Jesulno de Arruda e José Bonifácio.
F9: matéria do jornal A Folha de 24/07/1968.

Fonte: acervo da Fundação PróMemória de São Carlos, 1968 


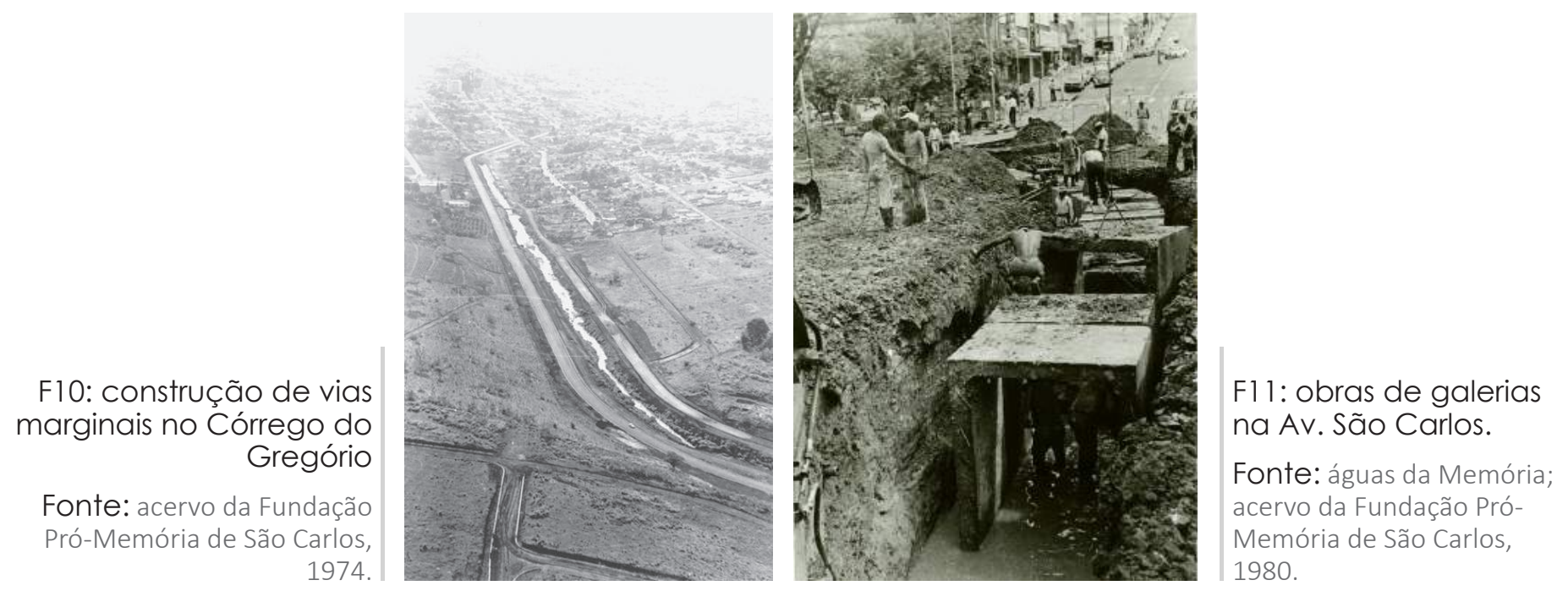

Em 1971 foi aprovado o Plano Diretor de Desenvolvimento Integrado, que foi elaborado com participação do Centro de Estudos e Pesquisas de Administração Municipal (CEPAM), do Instituto Brasileiro de Administração Municipal (IBAM) e da Escola de Engenharia de São Carlos (EESC). O diagnóstico elaborado nesse momento apontou a falta de diretrizes claras de uso e ocupação do solo, a deficiência no traçado viário, a dificuldade de travessia dos córregos, a falta de controle na implantação de novos loteamentos e os problemas relacionados às habitações localizadas em regiões sem a infraestrutura necessária (LIMA, 2008).

Uma das diretrizes do PDDI foi a definição de um anel viário que seria constituído pelas avenidas marginais dos córregos Tijuco Preto, Gregório e Monjolinho. Apesar de o anel viário não ter sido concluído, as avenidas construídas nos fundos de vale destes três córregos desempenharam a função de vetores de expansão da cidade (ANELLI, 2005; LIMA, 2008). Estas práticas intensificaram o caráter de barreira dos cursos d'água, visto que, apesar de conectar regiões da cidade, as avenidas marginais promoveram a fragmentação do espaço na escala local, segregando cada vez mais os cursos d'água do cotidiano urbano.

O PDDI também possibilitou a constituição de leis que reestruturaram a legislação urbanística de São Carlos: a lei de perímetro e zoneamento (Lei no 6871/1971, modificada pela Lei no 6878/1972), a lei de edificações 
(Lei no 6870/1971, modificada pela Lei no 6910/1972) e a nova lei de loteamentos (Lei no 6808/1971).

A formulação de um conjunto de disposições legais nesse período foi confrontada com a crescente força do mercado imobiliário que, ou agia à margem da legislação, ou encontrava brechas nas mesmas, de modo a permitir a implantação de loteamentos de maneira mais lucrativa. Enquanto os novos loteamentos seguiam o padrão de ocupação extensa com baixas densidades, o centro da cidade de São Carlos passou por outras transformações, incluindo seu adensamento, alteração de usos e verticalização, motivados pelo PDDI (LIMA, 2008).

Tendo em vista o processo de crescimento de São Carlos ocorrido entre a década de 1940 e 1970, nota-se que os fundos de vale, em um primeiro momento, colocaram-se como áreas que restaram ao longo do processo de urbanização. No momento de elaboração do primeiro Plano Diretor da cidade (1962) foi vislumbrada a possibilidade de conceber essas áreas como espaços livres e vegetados. No entanto, com o abandono desse plano e a afirmação de novas tecnologias e ainda considerando que esses espaços ainda restavam livres em um contexto de crescimento do mercado imobiliário, os cursos d’água passaram a receber as obras de avenidas marginais que se estendem até os dias atuais. Essas avenidas passaram a estruturar as direções tomadas pela expansão da cidade segundo o modelo rodoviarista predominante no Brasil, principalmente a partir da segunda metade do século XX. Tal modelo incluiu essas áreas no jogo urbano, locais ideais para a construção de novos vetores de crescimento da cidade, impulsionados pela difusão do automóvel.

\section{A crescente expansão periférica e a elaboração de planos}

A partir do processo de abertura política ocorrido entre as décadas de 1970 e 1980, após o regime militar brasileiro, ocorreram transformações na gestão urbana, desencadeadas pela Constituição de 1988. Considerando o crescimento do mercado imobiliário pautado pela rentabilidade da terra, a década de 1980 foi marcada pela exacerbação do processo de periferização da cidade (MARICATO, 2000). Em São Carlos, foram implantados, nesse período, loteamentos mais distantes do centro da cidade, como o Bairro Cidade Aracy, na microbacia do córrego 
Água Quente. Esse processo foi contínuo a partir da década de 1990, com o surgimento de bairros cada vez mais distantes e a criação de uma relação dicotômica entre o norte da cidade, ocupado por empreendimentos de alto padrão, principalmente loteamentos fechados, e o sul, onde predominam os loteamentos destinados às camadas populares, como por exemplo, empreendimentos do Programa Minha Casa Minha Vida da Faixa 1, que vêm sendo construídos na margem esquerda do Córrego Água Quente (SCHENK; PERES; FANTIN, 2015).

Foi a partir da década de 1990 que passaram a ser introduzidas novas lógicas de planejamento e construção da cidade de São Carlos, no plano das disposições legais, associadas a questões socioambientais. A realização da ECO 92 e aprovação do Estatuto das Cidades deram visibilidade, no Brasil, ao debate ambientalista que já vinha ocorrendo desde os anos 1960 em outros países (HERZOG, 2013).

Nesse contexto, em 1995, a Associação para Proteção Ambiental de São Carlos (APASC) moveu uma ação contra a Prefeitura Municipal, que resultou na determinação da suspensão da construção de avenidas em fundos de vale sem licenciamento ambiental (ANELLI, 2007).

O momento da condenação coincidiu com a tomada de posse da nova gestão municipal em 2001, que optou por acatar as determinações e construir uma série de acordos de permuta das condenações por obras que pudessem mitigar os danos ambientais causados pela impermeabilização dos fundos de vale por infraestrutura viária. Foi elaborado um Plano de Mobilidade Urbana Ambientalmente Sustentável em 2002 que serviu como base para o Termo de Ajustamento de Conduta (TAC) celebrado entre sociedade civil e gestão municipal por intermédio do Ministério Público em 2005 (ANELLI, 2007).

Esse TAC não foi integralmente implantado. As obras realizadas consistiram na duplicação da Avenida Dr. Francisco Pereira Lopes ao longo do córrego Monjolinho e da Avenida Comendador Alfredo Maffei ao longo do córrego Gregório, que, com afastamentos da margem dos cursos d’água, permitiram a reconstituição de trechos de Área de Preservação Permanente e a renaturalização de trecho do córrego Tijuco Preto (ANELLI, 2007).

De maneira geral, conforme consta no Relatório do Plano Municipal de Saneamento de São Carlos (2012), o TAC prevê um total de vinte e sete intervenções nos córregos Tijuco Preto, Monjolinho e Gregório, as 
F12: ações previstas no TAC das avenidas marginais.

Fonte: elaborado a partir de informações do Relatório do Plano Municipal de Saneamento de São Carlos, 2012; carta de hidrografia da PMSC, 2015 e imagem do Google Earth.

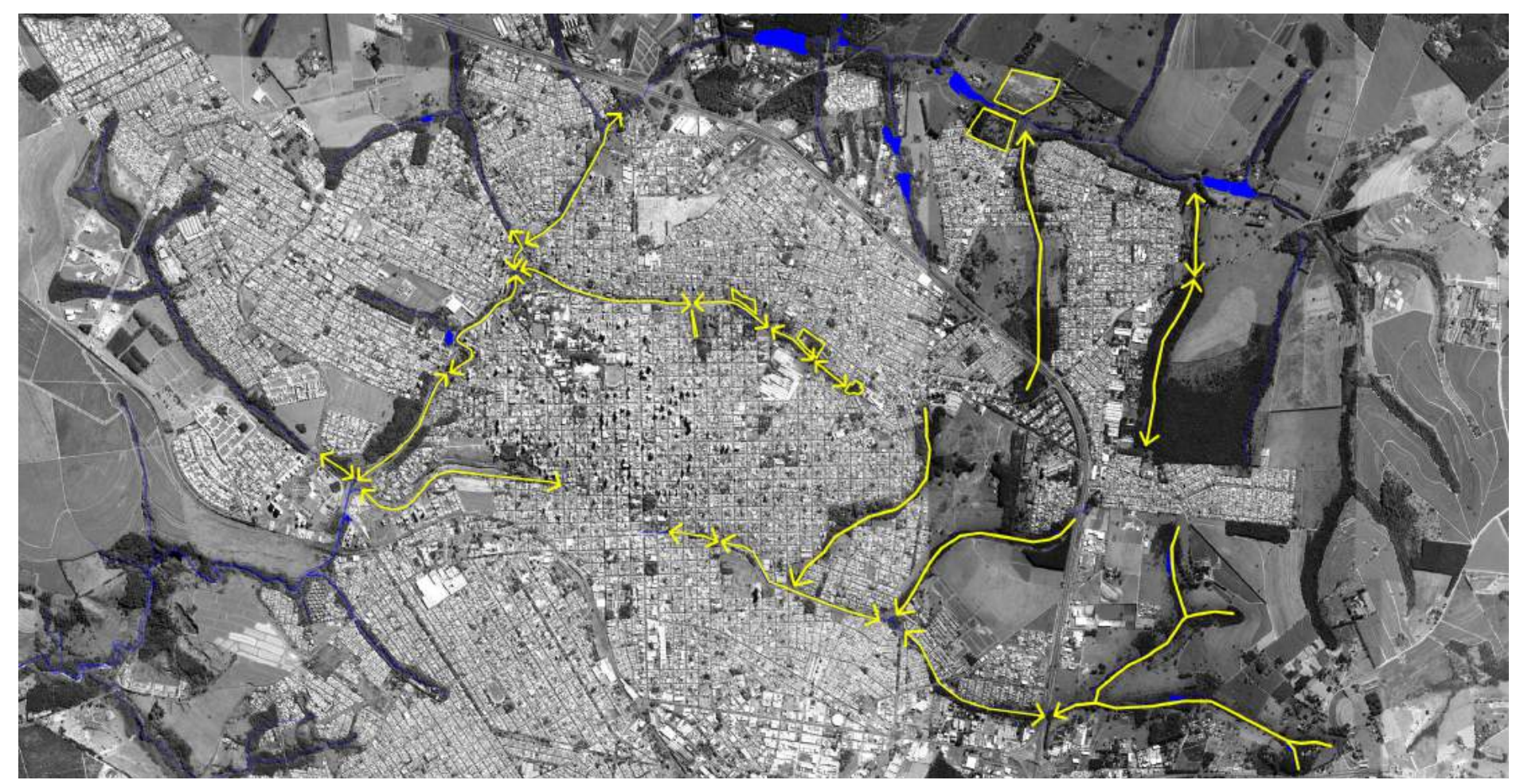

quais consistem essencialmente na recuperação de mata ciliar ao longo dos cursos d'água e nas nascentes e no controle de erosão e assoreamento, incluindo áreas públicas e privadas. Para alguns locais, foi definida a diretriz de implantação de parques lineares, entretanto, tal determinação tem esbarrado com a ausência de fontes de financiamento (SÃO CARLOS, 2012).

Algumas diretrizes estabelecidas pelo TAC foram incorporadas ao Plano Diretor de 2005, que representa outro momento relevante para a introdução de novas lógicas de construção do espaço urbano de São Carlos.

As cartas do Plano Diretor de 2005 explicitam um esforço para a descrição das condições ambientais e socioeconômicas materializadas no território de São Carlos. Esta descrição das características do sítio e formas de distribuição da população serviu de suporte para a proposta de zoneamento de acordo com fragilidades 
socioeconômicas e ambientais, considerando a bacia hidrográfica como unidade territorial de paisagem e planejamento (SÃO CARLOS/FUSP, 2011).

A princípio, a revisão do Plano Diretor iniciada em 2011 buscou dar continuidade aos esforços iniciados pelo PD de 2005. A partir de um convênio entre o Instituto de Arquitetura e Urbanismo da Universidade de São Paulo, por meio da Fundação USP, e a Prefeitura Municipal, foi elaborado um novo diagnóstico do município apontando as principais questões que deveriam orientar o desenvolvimento da cidade.

No entanto, os produtos desse enfrentamento foram abandonados pela gestão que tomou posse em 2012. Diante de incongruências geradas por essa administração, em relação aos instrumentos de planejamento urbano definidos pelo Estatuto das Cidades (2001), o Ministério Público determinou a constituição de um Núcleo Gestor Compartilhado para retomar o processo participativo de revisão do Plano Diretor. Foi realizada uma série de negociações entre agentes ligados principalmente ao mercado imobiliário e agentes que buscavam dar continuidade às estratégias iniciadas em 2005, em especial as Universidades, instituições públicas e ONGs relacionadas ao meio ambiente (SCHENK; PERES; FANTIN, 2015). Os produtos finais foram consolidados com a aprovação da revisão do Plano Diretor Municipal em 2016.

A comparação entre o Plano Diretor de 2005 e sua revisão permite identificar algumas questões relevantes associadas à relação entre cursos d'água e espaço urbano.

O perímetro urbano de São Carlos foi expandido no novo Plano Diretor, englobando áreas da região Sul, apesar dessa ser mantida como Zona de Ocupação Controlada. Com isso surgem incongruências, tendo em vista o modo como a cidade vem expandindo nesta direção, isto é, a partir da construção massiva de empreendimentos voltados para camadas populares com desenhos genéricos em locais sem a infraestrutura adequada. Assim, o novo perímetro urbano contribui para a continuidade de uma lógica de construção do espaço urbano nessa região que, segundo estudos realizados pelas Universidades, exacerbaria a segregação socioespacial já evidente na cidade. Também assinala a contínua degradação de uma região ambientalmente frágil que coincide com áreas de Recarga do Aquífero Guarani (SÃO CARLOS/FUSP, 2011). 


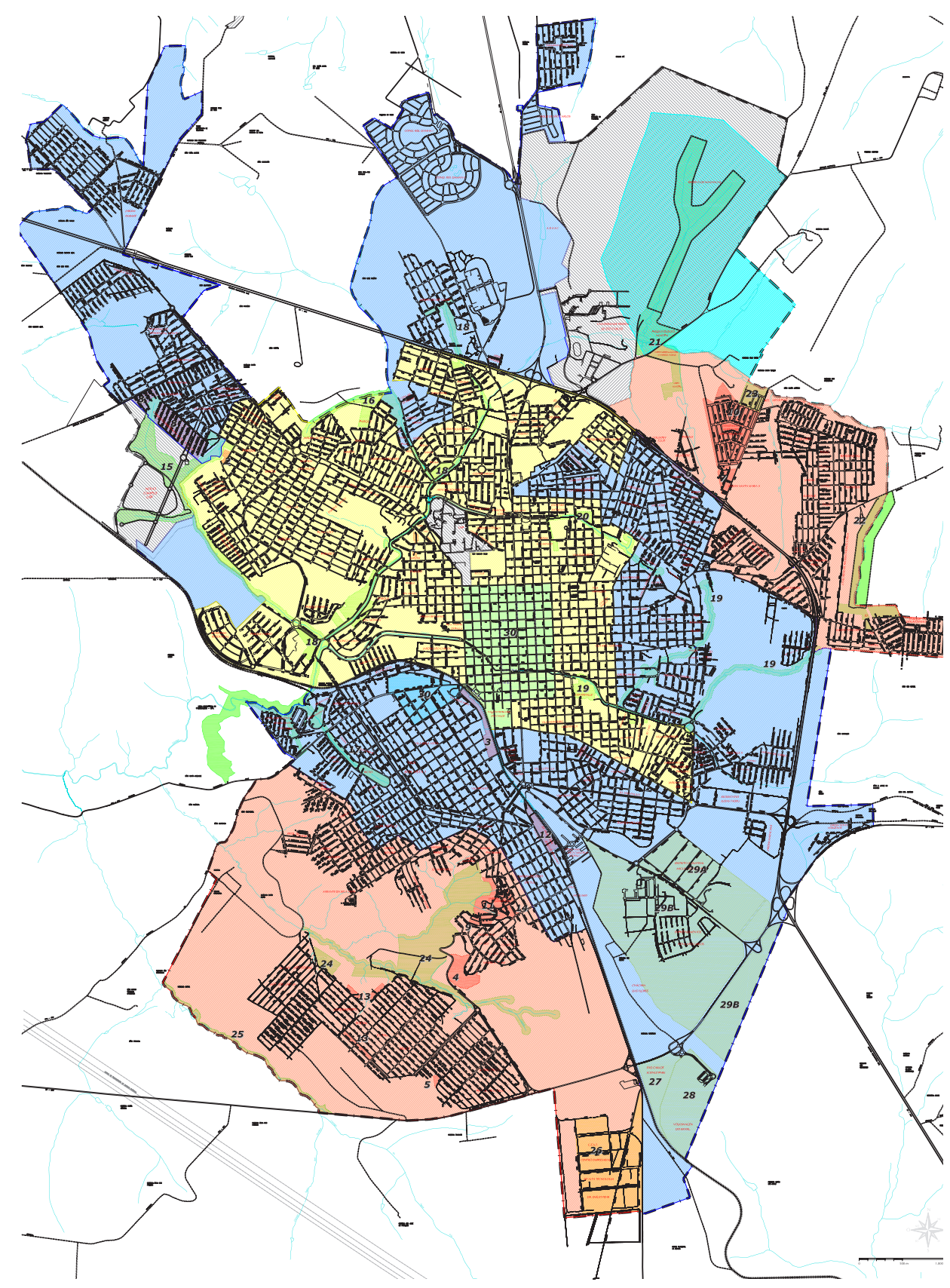

\section{Legenda}

$\square$ AEI Social $(1,2$ e 3$)$

AEI Ambiental

AEI Industrial

$\square$ AEI Histórico

A] AEI Histórico: sub-áreas com limitação de gabarito

$\square$ Zona 1 - Ocupação Induzida

$\square$ Zona 2 - Ocupação Condicionada

$\square$ Zona 3 - Recuperação e

Ocupação Controlada

Zona 5 - Proteção e Ocupação Restrita

(área interna ao perímetro urbano)

Campi Universitários

$\begin{array}{ll}\text { Rodovia } & --- \text { - Perímetro Urbano } \\ \text { Córrego } & \text { Limite do Município }\end{array}$

\section{AEI Social tipo 1 :}

$\mathbf{0 2}$ - do Parque Santa Felícia Jardim

03 - da Vila Ferroviária

("Orfanato")

06 - do Santa Maria

07 - do Santa Maria II

\section{AEI Social tipo 2:}

08 - do Loteamento Social Santa Angelina 09 - da Vila Monte Carlo (CDHU)

10 - do Loteamento D. Constantino

11 - do Jardim Gonzaga e Vila Monte Carlo (programa "Habitar Brasil BID")

AEI Social tipo 3:

3 - do Loteamento Social Cidade Aracy

Conzaga

F13: AEls Urbanas do Plano Diretor de 2005.

Fonte: PMSC. 2005.
AEI Ambiental:

16 - do Córrego do Cambuí - Santa Paula (Parque do Bicão) - Pedreiras (parte na Macrozona de uso Multifuncional Rural)

dromo - Rot. do Cristo

19 - do Gregório - Lazzarini - Sorregoti

20 - do Tijuco Preto

22 - do Parque São Rafael (parte na Macrozona de uso Multifuncional Rural)

23 - do D. Constantino Amstalden ("São Carlos VIII")

$25-$ do 2 . Con

AEI Industrial:
26 - do CEAT - Centro Empresarial de Alta Tecnologia

27 - do São Carlos Science Park

29 - do Parque Industrial Miguel Abdelnur:

29A - uso predominantemente industrial

29B - uso misto

30 - AEI Histórico 


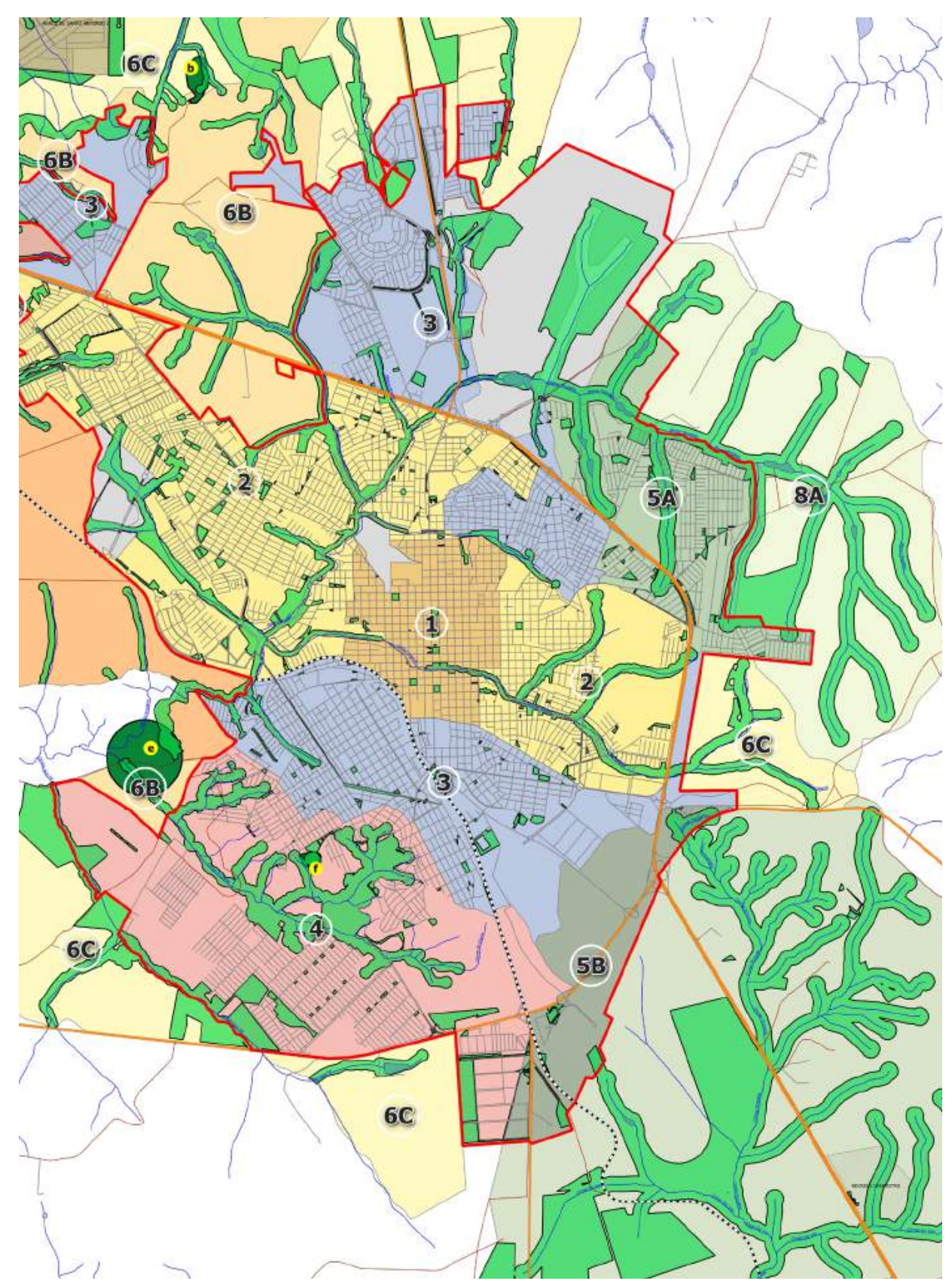

\section{Legenda}

$\square$ Municípios confrontantes

Limite municipal
Perimetro Urbano Proposto

Vias

\section{- Estradas}

$\approx \approx$ Ferrovias

- Rodovias

- Vias Unbanas

Hidrografia - escala 1:50.000

Represas - reservatórios - escala 1:50.000

\section{AEIs Ambientais}

$\square$ AECRA

AIA

\section{Zoneamento}

1 Ocupação Consolidada

2 Ocupação Induzida

3 Ocupação Condicionada

4 Qualificação e Ocupação Controlada

5A Proteção e Ocupação Controlada - SUC Monjolinho-Espraiado

5 B Proteção e Ocupação Controlada - SUC Manancial do Feijão

6A Regulação e Ocupação Controlada de Maior Densidade

6A Regulação e Ocupação Controlada de Maior Densidade

6B Regulação e Ocupação Controlada de Média Densidade

6C Regulação e Ocupação Controlada de Menor Densidade

7 Proteção, Regulaçăa e Ocupaçăa Especifica

8A Proteção e Ocupação Restrita do Monjolinho-Espraiado

8B Proteção e Ocupação Restrita do Manancial do Feijão

Campus Universitário

Loteamentos rurais regulares

F14: AEls Ambientais do Plano

Diretor de 2016.

Fonte: PMSC. 2016 
Outro ponto a ser observado diz respeito à determinação de Áreas Especiais de Interesse Ambiental, que segundo a carta apresentada nos produtos consolidados de 2016, apresenta grande quantidade de Áreas de Preservação Permanente ao longo dos cursos d'água. No entanto, a confrontação dessa informação com a realidade local explicita sua dimensão ilusória, uma vez que parte das áreas delimitadas na carta na verdade se referem a áreas já ocupadas ou consolidadas como as avenidas marginais.

A terceira questão que emerge da comparação entre os planos está associada às zonas de ocupação induzida que abrangem trechos dos córregos Monjolinho, Tijuco Preto e Gregório. Por um lado, tal determinação visa diminuir a quantidade de vazios urbanos de modo a reduzir mecanismos de especulação imobiliária e espraiamento da cidade sem a necessária infraestrutura. Por outro lado, considerando a quantidade relevante de vazios urbanos ao longo de cursos d'água, se sua ocupação não for orientada por diretrizes que busquem resguardar esses córregos, pode ocorrer a reprodução do modo de construir a cidade que desconsidera os processos naturais, o que repercute nos diversos problemas de enchentes e poluição.

Frente à permanência dos problemas de enchente na cidade ao longo do tempo, em 2009 foi iniciada a elaboração do Plano Diretor de Drenagem Urbana Ambientalmente Sustentável do Município de São Carlos pela empresa SHS Consultoria e Projetos de Engenharia SS Ltda, com fiscalização da Secretaria Municipal de Obras Públicas.

O plano prevê um conjunto de intervenções na rede hídrica da bacia hidrográfica do Córrego Monjolinho, pautando-se pela realização de visitas técnicas e um amplo levantamento cartográfico com uso de Sistemas de Informação Geográfica (SIG), que foi capaz de reunir as características gerais do território municipal quanto à geomorfologia, geologia, pedologia, zoneamento e o uso e ocupação do solo. Partindo dessa base de informações, o plano prevê a realização de medidas estruturais e não estruturais. As medidas estruturais são apresentadas a nível de anteprojeto e consistem, sobretudo, na construção de reservatórios de detenção on-line (no próprio curso d'água) e off-line (quando os volumes de água são desviados da rede de drenagem natural), bem como a construção de canais. As medidas não estruturais são ações voltadas para a gestão do plano, como capacitação técnica de funcionários da Prefeitura Municipal e estabelecimento de disposições legais, além de medidas compensatórias 

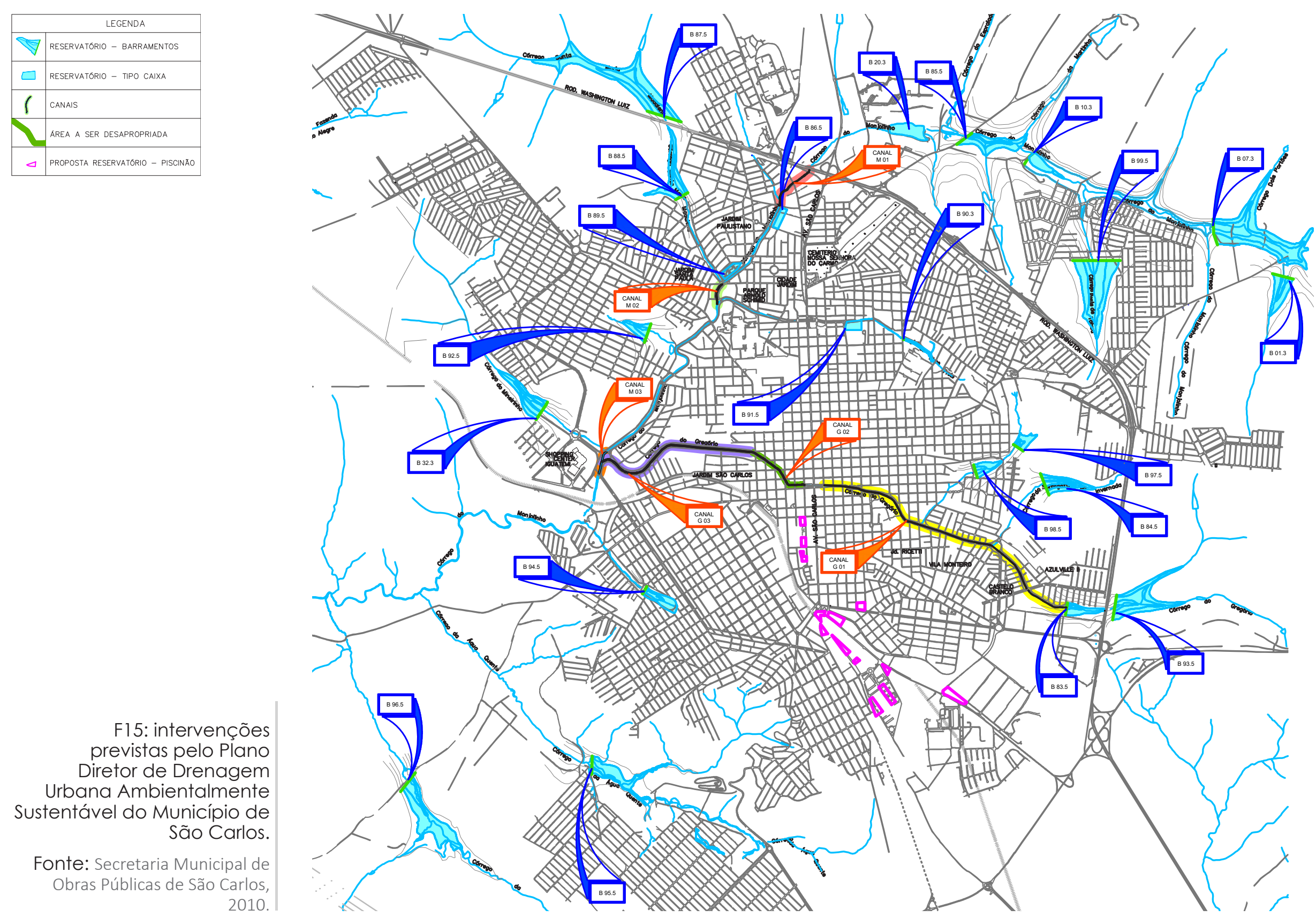
como retenção de água no lote, uso de águas pluviais e uso de pavimentos permeáveis. A execução do plano está ocorrendo gradualmente, conforme são angariados recursos financeiros (SÃO CARLOS/SHS Ltda., 2011).

Este plano contribui para a construção de uma relevante base de informações sobre o território da bacia hidrográfica do Monjolinho e apresenta a qualidade de propor diretrizes segundo um olhar sistêmico. No entanto, suas ações se mantém dentro da lógica de uma visão de sobrevoo que busca o controle dos processos naturais pela técnica. Além disso, sua eficiência depende da concretização de todo o conjunto de intervenções, porém, as obras ocorrem gradualmente, conforme são disponibilizados recursos financeiros.

\section{Observações}

Considerando o panorama de construção da cidade de São Carlos aqui apresentado, destacam-se dois grupos de agentes que orientaram esse processo: o poder público (nos âmbitos federal, estadual e municipal) e as elites econômicas (barões do café, donos de indústrias, empreendedores do mercado imobiliário e proprietários de terra).

Nos distintos momentos do desenvolvimento urbano de São Carlos, o poder público, em âmbito municipal representado incialmente pela Câmara Municipal e depois pela Prefeitura Municipal, foi responsável pela elaboração de uma sequência de disposições legais que influenciaram a conformação da cidade e estiveram vinculadas ao contexto político e econômico nacional. Essas disposições não necessariamente organizaram o crescimento urbano, mas impulsionaram certas lógicas de urbanização. Por exemplo, a ausência de parâmetros claros nessas leis possibilitou a expansão da cidade de acordo com os interesses do mercado de terras, sendo que o perímetro urbano foi sendo modificado de acordo com a implantação de novos loteamentos, como aponta Renata Priore Lima (2008).

As elites econômicas variaram em cada período do desenvolvimento da cidade, vinculando-se à produção cafeeira, à ascensão da indústria e ao aquecimento do mercado imobiliário. Frequentementeestas elites econômicas 
coincidiram com os representantes do poder público. Detentores da terra urbana, esses grupos contribuíram para reproduzir padrões de urbanização segundo seus interesses. Desde investimentos em infraestrutura em áreas estratégicas da cidade que beneficiaram o funcionamento das atividades produtivas e comerciais, até a implantação de loteamentos de forma precária com desenhos que permitissem maior lucratividade.

Diante das determinações destes dois grupos de agentes, relacionadas ao contexto político e econômico nacional, o espaço urbano foi sendo construído predominantemente segundo lógicas específicas de cada época, que priorizavam a estruturação eficiente do espaço para os fluxos produtivos e de consumo. As características do sítio natural e os processos naturais não se configuravam como fator determinante para as diretrizes de urbanização. Esse quadro começou a ser alterado na década de 1990, quando a formulação de disposições legais começou a se apoiar em bases socioambientais.

Segundo o arcabouço tecnológico de cada época, os córregos se colocaram, de maneira ambígua, como obstáculos à expansão urbana ou como elementos norteadores desse crescimento. A materialização de determinadas lógicas de organização do espaço urbano que visaram à eficiência dos fluxos produtivos e à rentabilidade da terra contribuiu, portanto, com a construção de um problema. Esse problema é representado principalmente pela ocorrência de enchentes, noticiadas desde finais do século XIX na região central da cidade e expandidas para áreas mais distantes, de acordo com a continuidade de certas lógicas de construção do espaço urbano.

Ao percorrer a historiografia sobre o processo de urbanização de São Carlos, é possível notar que o córrego Gregório é o curso d'água que mais se coloca em evidência nos documentos e narrativas históricas, considerando a rede hídrica da bacia hidrográfica do córrego Monjolinho. Por coincidir com o território inicial da cidade, o córrego Gregório acumulou uma série de testemunhos de cada época e participou de relatos que constituíram a memória sobre a cidade.

Por sua vez, o córrego que dá nome à bacia pouco participou das dinâmicas urbanas iniciais, mantendose fora do alcance da cidade até metade do século XX (exceto pelo seu encontro com o Picadão de Cuiabá, que 
não conformou o mesmo ponto de atração identificado no córrego Gregório). O córrego Monjolinho parece não participar dos relatos que constroem a memória de São Carlos e se apresenta no contexto atual como paisagem genérica, ou como fonte permanente de empecilhos para o cotidiano urbano, em seus momentos de cheia.

F16: enchente no bairro Lagoa Serena em 1975 (córrego Simeão).

Fonte: acervo da Fundação PróMemória São Carlos, década de 1975.
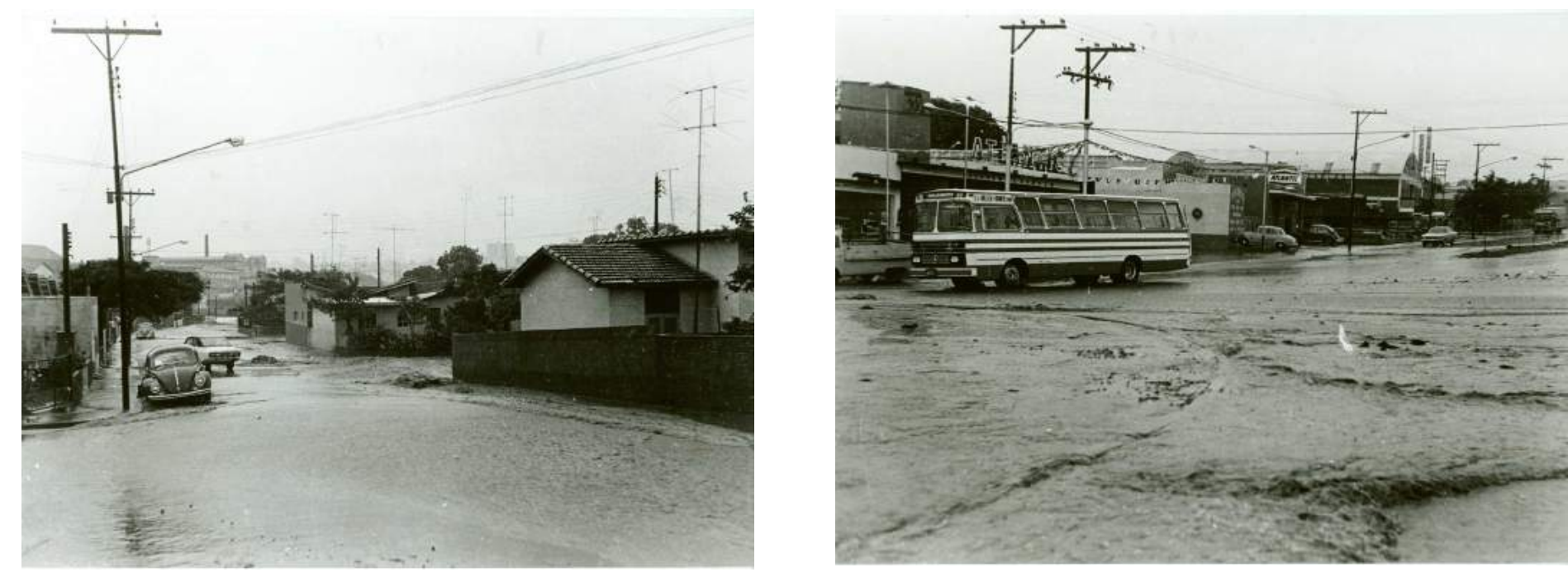

F17: enchente em 1999

lencontro dos córregos Gregório e Mineirinho com Monjolinho)

Fonte: acervo da Fundação PróMemória São Carlos, década de 1999.

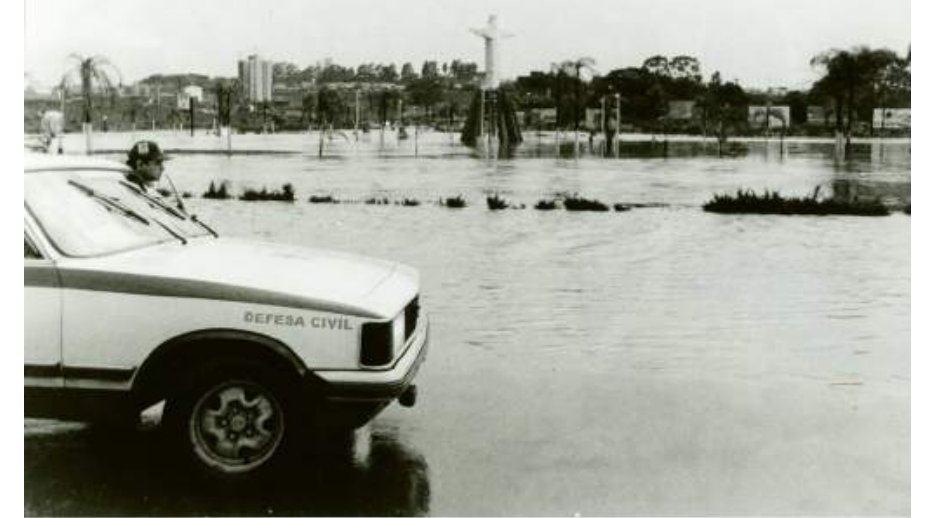

F18: enchente na avenida Getúlio Vargas em 1975 (córrego Simeão).

Fonte: acervo da Fundação PróMemória São Carlos, década de 1975. 

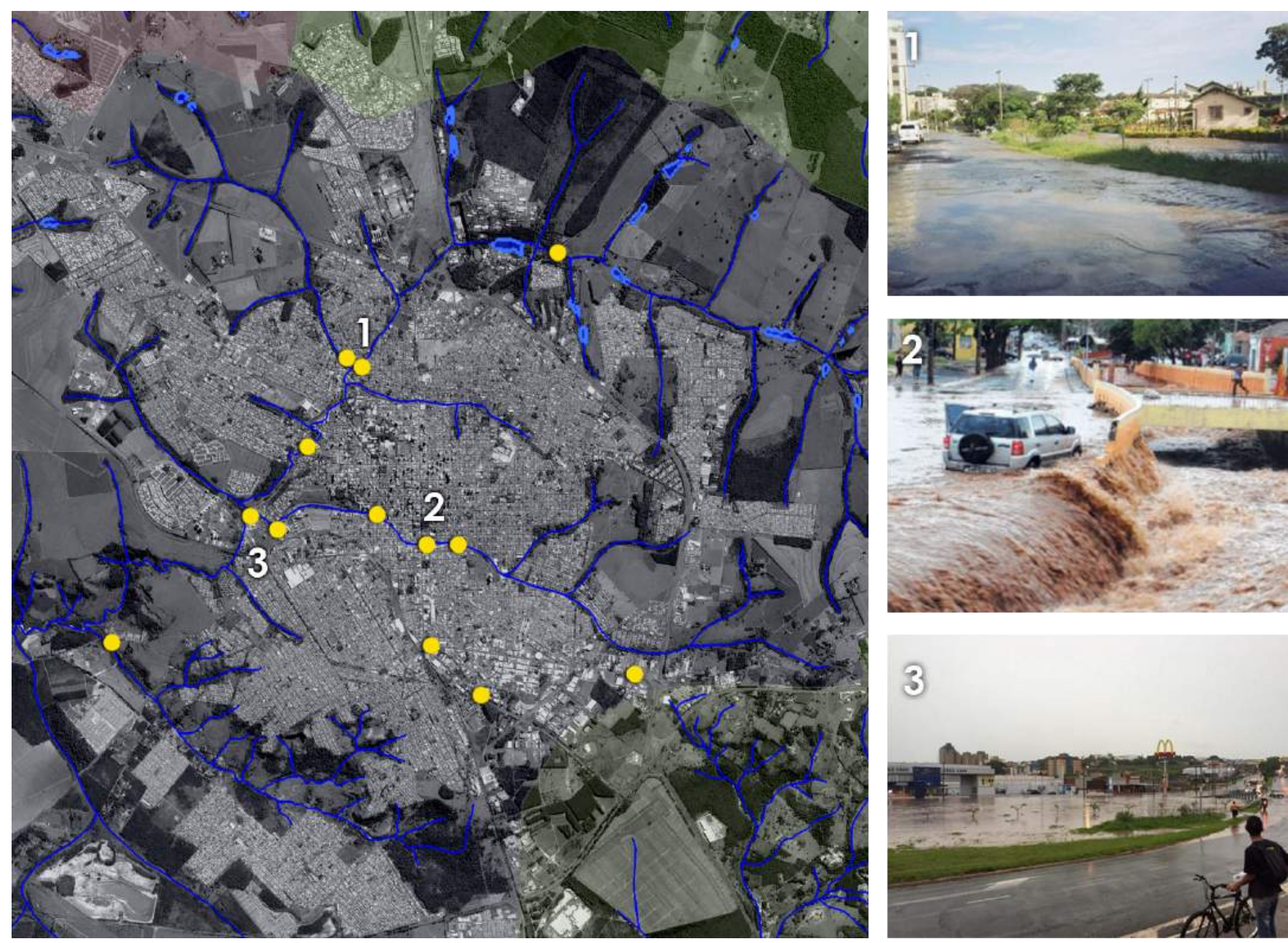

F19: Pontos suscetíveis a enchentes

Fonte: Elaborado a partir de carta de hidrografia do IBGE; imagem do Google Earth e informações de matéria do G18; (1) OSCIP Veredas; (2) A Folha Paulista, 2015; (3) G1/ EPTV, 2013.

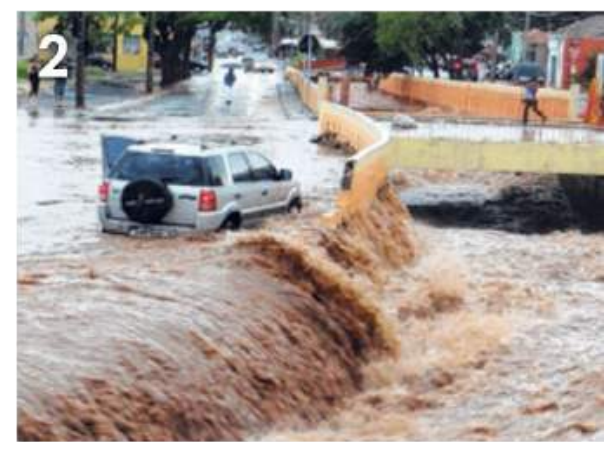

3

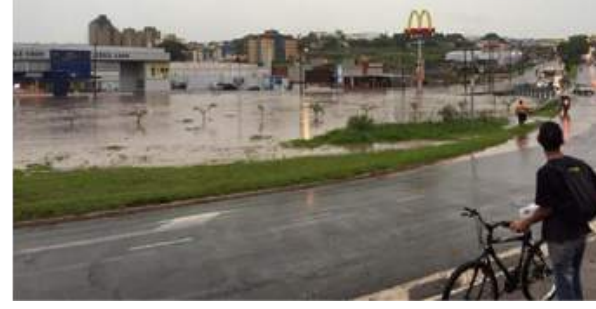

Disponivel em <http:// g1.globo.com/sp/sao-carlosregiao/noticia/placas-sobre-riscode-alagamentos-sao-instaladasem-pontos-de-sao-carlos.ghtml> acesso em Junho de 2017. 
3 - Relatos

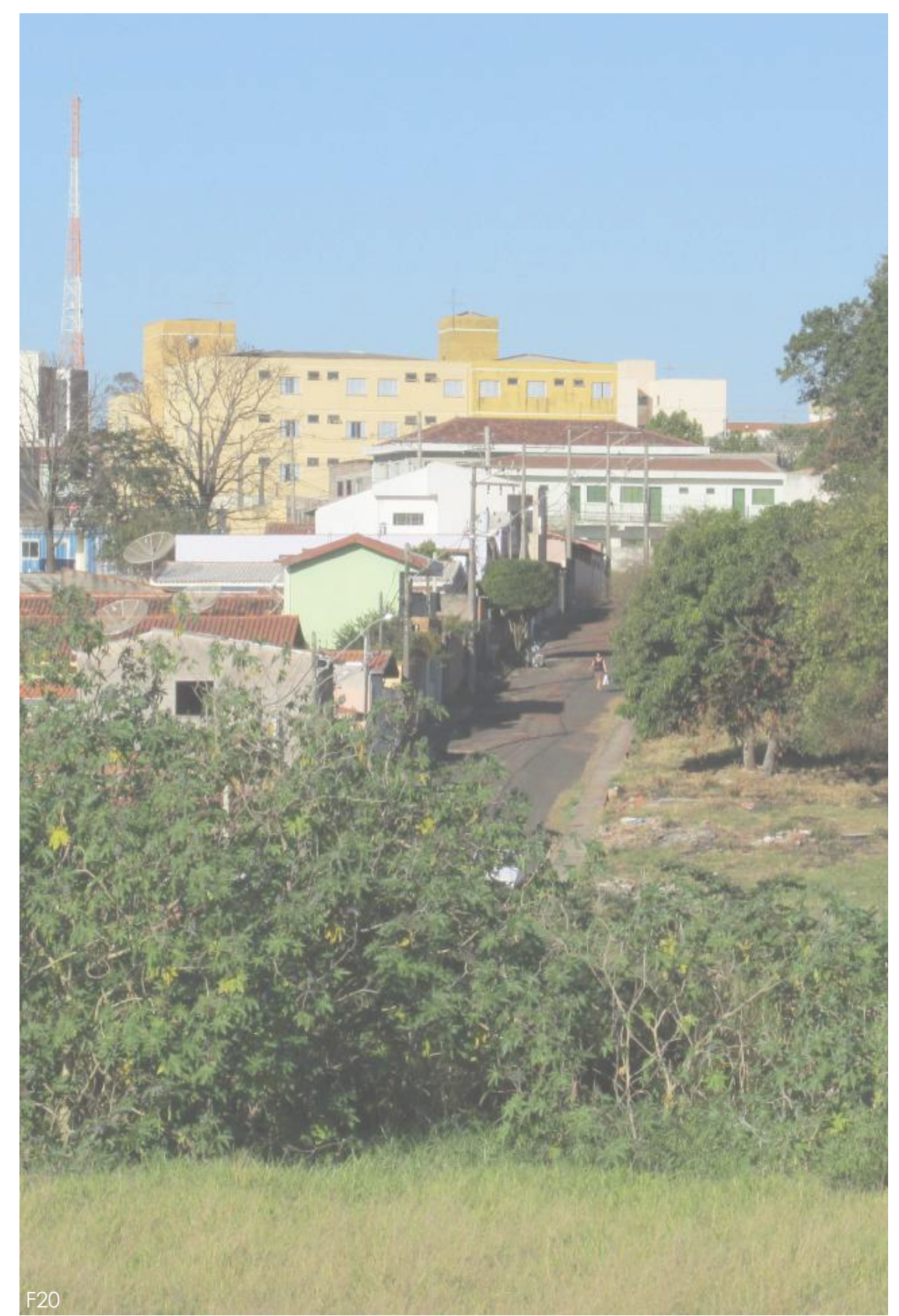


F21: sequência de paisagens.

Fonte: elaborado a partir de carta de hidrografia do IBGE e imagem do Google Earth. 


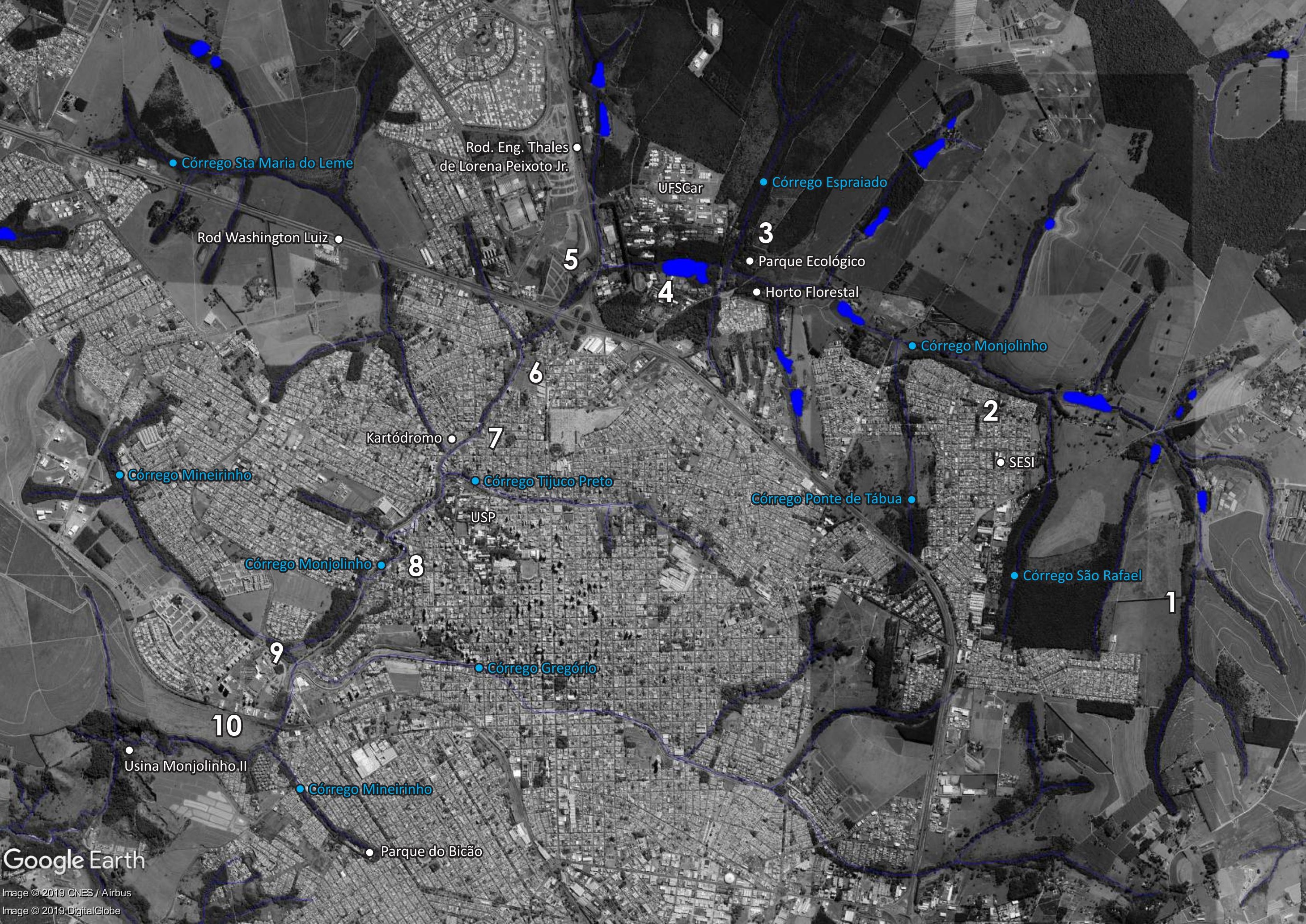




\section{DESCOBRINDO PAISAGENS}

\section{Uma sequência de paisagens}

O córrego Monjolinho recolhe as águas que esculpem o território urbano de São Carlos e alinhava os fragmentos de história da cidade. Para quem pouco conhece suas paisagens, apresenta-se como um curso d'água genérico entre avenidas marginais que percorrem espaços vazios.

1 | As nascentes que alimentam seu curso inicial se localizam na região leste, extrapolando os limites do perímetro urbano. Esse conjunto é definido pelos técnicos como área de mananciais, conforme a Lei 13.944, de 12/12/2006 e permeia um território de retalhos produtivos, segmentados pelas Áreas de Preservação Permanente, únicos testemunhos de sua situação verdejada original.

2 | O contato direto entre o córrego Monjolinho e a cidade nessa região se dá esporadicamente. Um desses momentos ocorre no bairro periférico Maria Stela Fagá, pedaço de cidade confinado entre os córregos São Rafael e Ponde de Tábua e o próprio Monjolinho. Esse bairro dá as costas para o curso d'água e suas bordas a norte fazem parte de uma paisagem indeterminada que participa de um limite, um espaço entre (cidade e campo). Caminhando a partir da cumeada (na região do SESI) em direção ao vale do Monjolinho, é possível visualizar o que está para além desse fragmento urbano e, conforme se dá a aproximação com o córrego, esse panorama é acessível apenas pelas frestas da vegetação que cobre o curso d’água.

3 | O Monjolinho segue seu curso até atravessar um conjunto de parques, o Horto Florestal Municipal Navarro de Andrade e o Parque Ecológico Municipal (que integra o conjunto de parques urbanos instituído pelo Decreto no 170 de 17/07/2017); nesse mesmo local o córrego é evidenciado por uma das funções essenciais de suas águas para a cidade por meio da presença de uma estação de captação superficial de água, uma das principais fontes de abastecimento do Município promovido pelo Serviço Autônomo de Água e Esgoto (SAAE). 
4 | Logo em seguida, o córrego Monjolinho se faz presente dentro do campus da Universidade Federal de São Carlos, onde se alarga em um lago e se torna pano de fundo, cenário naturalizado para os fluxos rotineiros que vão e voltam dos departamentos e do restaurante universitário.

5 | Na sequência, retira-se imperceptivelmente sob a Avenida do Bosque, avançando pela propriedade da São Carlos S/A Indústria de Papel e Embalagens; atravessa a Rodovia Engenheiro Thales de Lorena Peixoto Júnior, que promove a ligação com a cidade de Ribeirão Preto; percorre uma pequena área em processo de loteamento até alcançar a Rodovia Washington Luiz, quando abandona seu contexto de borda, mas sem deixar de se apresentar como paisagem de margem.

6 | Entre a Rodovia Washington Luiz e o Parque do Kartódromo, o córrego Monjolinho atravessa uma sequência de paisagens indeterminadas, de vazios (CARERI, 2013), um campo cego (LEFEBVRE, 2002). Somente a aproximação e a caminhada atenta permitem identificar momentos de contato entre curso d'água e cidade: instalações improvisadas como bancos, balanços, casinhas de cachorro; paisagismos realizados pelos próprios moradores, com o plantio de espécies de suculentas e palmáceas.

7|O ponto de inflexão que representa a transformação brusca dessa paisagem é a região do parque do Kartódromo que, apesar de suas dimensões reduzidas, é intensamente utilizado para o esporte, para o estar e para a realização de feiras. Mesmo que esse espaço livre faça parte da rotina da população, o córrego Monjolinho não participa dessas dinâmicas e se coloca como limite entre um espaço claramente funcional e determinado em sua margem direita e um pedaço de cidade incompleto e indeterminado em sua margem esquerda, onde edificações são distribuídas em um território em que, sem o auxílio de uma carta de arruamentos da prefeitura e sem a demarcação de uma pavimentação, não se sabe muito bem onde estão as ruas e onde estão as propriedades públicas ou privadas que ainda não foram ocupadas. É um silêncio que se coloca bem no meio da cidade.

Nesse trecho, o Monjolinho recebe as águas do córrego Santa Maria do Leme...

O córrego Santa Maria do Leme nasce em um território atualmente com intenções de ocupação, ainda não concretizadas ou em andamento, na região norte do perímetro urbano. Esse curso d'água configura até o Parque do Kartódromo um percurso silencioso 
que atravessa uma região residencial e apresenta sinais modestos de apropriação de suas margens, como mesas, bancos e uma venda de laranjas. Alinhava dois espaços livres públicos relevantes para o cotidiano da cidade, os Bosques Cambuí e Santa Marta, que proporcionam uma experiência de contato com a natureza em meio à cidade. Existem fortes vínculos de identidade entre o curso hídrico e a população local, que se organizou por meio da OSCIP Veredas e manifesta suas expectativas para essa microbacia hidrográfica através de ações como os "Seminários Microbacia Santa Maria do Leme" que ocorrem anualmente no SESC São Carlos.

...e, logo em seguida, o Monjolinho recebe as águas do córrego Tijuco Preto...

O córrego Tijuco Preto nasce na região leste já englobada pela cidade. Esse córrego se coloca como situação peculiar na cidade de São Carlos por ter sido alvo de obras de renaturalização de seu curso em atendimento ao TAC das Avenidas Marginais (ver capítulo 2). No entanto, recentemente recebeu novamente obras de avenidas marginais, voltando a caminhar em direção ao aspecto que adquire nas imediações do Campus I da USP, onde é cercado por avenidas que deixam faixas estreitas de solo permeável.

... e a partir desse ponto, o Monjolinho prossegue seu percurso por um território de distinta qualidade, que parece abandonar definitivamente a indeterminação característica de sua margem esquerda.

8 | Inicia-se um longo trecho composto por paisagens determinadas pela função, pelos fluxos utilitários. A sequência de paisagens determinadas incluem parque projetado, avenidas marginais, Áreas de Preservação Permanente, muros altos que delimitam o público e o privado e um curto segmento de ciclovia. Nesse trecho que percorre o espaço entre a região do Campus I da Universidade de São Paulo e o Shopping Iguatemi, o córrego não é invisível. Talvez justamente pela sua visibilidade exacerbada, pela tentativa de purificar e limpar essa paisagem determinada, onde cada coisa deve desempenhar uma função, o Monjolinho se apresenta como monotonia, repetição, um outro tipo de vazio: vazio de apropriações, vazio de impresibilidades. É um lugar de passagem e seu próprio curso define um amplo espaço entre: um ponto de partida e um ponto de chegada, entre os quais nada acontece, apenas a passagem.

Nas proximidades do shopping, o Monjolinho recebe as águas do córrego Mineirinho (por uma galeria) e do córrego Gregório... 
O córrego Gregório nasce na região leste da cidade. Participou da constituição inicial da cidade e, ao percorrer seu curso atualmente, é possível apreender a sobreposição de vários momentos do processo de urbanização. O trecho que atravessa o centro histórico de São Carlos se encontra em registro artificioso, completamente impermeabilizado, tornando-se invisível sob a praça do Mercado Municipal. Na medida em que deixa o centro da cidade, configura-se de maneira semelhante ao córrego Tijuco Preto e suas avenidas marginais, com a diferença de que o córrego Gregório é acompanhado por um trecho de pista de caminhada e ciclovia de aproximadamente 1600 metros que são utilizadas com frequência pela população.

9 | O Monjolinho atravessa a Rotatória Antônio Adolpho Lobbe (ou Rotatória do Cristo), que reúne águas e vias e apresenta diversos aspectos de uma paisagem determinada, desde sinalizações de trânsito no solo pavimentado, semáforos e placas informativas, até as mudas de plantas ornamentais cuidadosamente separadas por espaços regulares. Espaço organizado, é palco de enchentes anuais, noticiadas pelos jornais locais, juntamente com o anúncio das futuras obras de engenharia que solucionarão definitivamente o problema historicamente construído.

Após atravessar esse espaço regido por movimentos frenéticos, o Monjolinho recebe as águas do córrego Medeiros...

O córrego Medeiros teve sua nascente envolvida por um parque modernista na década de 1980, o Parque do Bicão. Até alcançar o córrego Monjolinho, o Medeiros apresenta alguns sinais de uso de suas margens pela população, com a presença de mesas e bancos, dos mais improvisados até as peças pré fabricadas de concreto. Em determinado ponto, tem suas margens unidas por uma ponte de madeira que permite uma perspectiva diferente de seu curso.

... e em seguida, o Monjolinho margeia pedaços intermitentes de cidade, retomando suas características de indeterminação.

10 | Entre córrego e cidade, coloca-se um espaço vegetado que bloqueia a visualização do curso d’água e que, em alguns trechos, é demarcado por cercas e decorado por espécies vegetais diversas, aparentemente plantadas pelos próprios moradores. Como ponto provisoriamente final da mancha urbana (porque em breve a gleba deve ser ocupada por um novo loteamento), há uma praça composta por elementos ao mesmo tempo usuais e inusitados: uma cadeira de aço, uma churrasqueira revestida com retalhos de azulejos, um totem de madeira. 
A partir dessa pequena praça é testemunhada, pelo rastro indicado pela vegetação que margeia o córrego, a retirada do Monjolinho do perímetro urbano e do alcance dos olhos da cidade.

\section{Categorias e desdobramentos}

Através desse percurso que descreve a existência do córrego Monjolinho dentro do perímetro urbano de São Carlos, é possível identificar duas categorias que reúnem um conjunto de paisagens, que serão denominadas Paisagens Determinadas e Paisagens Indeterminadas. Essas categorias não pretendem fragmentar paisagens e encaixa-las em especificações precisas. Determinação e indeterminação se articulam e se engendram mutuamente.

A todo momento, a paisagem determinada anseia por controlar o que há de efêmero, múltiplo, imprevisível, impreciso. Ela é funcional: separa e organiza.

Nos espaços concretados e asfaltados, bem como nos maciços arbóreos (APPs) que se colocam entre a avenida marginal e o córrego, está presente essa paisagem resultante de um processo histórico que construiu uma mentalidade apoiada na busca pela eficiência dos fluxos, dos processos produtivos e de consumo, através do controle da natureza pela técnica.

Paisagem de movimento e de fluidez. Tem clareza, é de fácil visibilidade e compreensão. Filtra aquilo que há de indeterminado, aquilo que foge do controle, deixando as impurezas à margem, nas bordas esquecidas entre uma função e outra: na margem do rio, no limite da propriedade, na fresta do concreto.

Porém, não há intenção utilitária capaz de permanecer por inteiro. A todo momento, pulsos daquilo que não se tem domínio corroboram o desmanche das paisagens determinadas, pretensamente estáticas e conclusas. É necessário o emprego insistente de esforços e de uma rígida rotina para manter essas paisagens intactas, polidas, podadas, limpas, em funcionamento; para mantê-las determinadas. Assim como uma superfície branca, na qual qualquer mudança de tonalidade denuncia a quebra de sua homogeneidade (LASSUS, 1994), uma paisagem 
determinada é facilmente perturbada por qualquer aspecto que transgrida seu domínio: qualquer rachadura no concreto, qualquer vegetação que cresce além do desejado pode expor uma falha; a falta de manutenção; o descaso; a ineficácia.

A paisagem indeterminada está presente naqueles lugares deixados à margem, abandonados, ignorados pelos intuitos funcionalistas, pelas instituições, pelo mercado ou pela população. Mas está também dentro da própria paisagem determinada, rachando sua superfície pretensamente uniforme.

O observador que apreende o território de cima, ou que se coloca dentro de um papel (o motorista), distancia-se dos fenômenos objetivos e subjetivos que constroem o mundo vivido e que diversificam as paisagens. Esse olhar transforma o mundo em homogeneidade, faz com que as paisagens determinadas ou indeterminadas sejam iguais dentro de sua categoria. Escapam a esse olhar as singularidades.

Aproximar-se do mundo vivido é a ação necessária para descobrir as frestas que racham a paisagem determinada ou que singularizam cada paisagem indeterminada.

Com a prática do caminhar, pode-se aproximar dessas paisagens e mergulhar em suas especificidades para verificar os desbobramentos de sua suposta determinação e monotonia.

Nas rachaduras aparecem as gramíneas, as bordas do concreto da calçada se esfarela e uma cascata de entulho desagua no córrego. Os resíduos produzidos pelo esforço de limpeza das paisagens determinadas são deixados nos espaços abandonados, esquecidos ou descartados.

Paisagens em decomposição. Aquela estrutura construída pela promessa de controle da natureza pela técnica não resiste aos movimentos da indeterminação; aqueles espaços que escondem o avesso da função recebem os entulhos produzidos pela utilidade.

As paisagens indeterminadas são transitórias e instáveis. Ao percorrer um espaço em distintos momentos, é provável que não seja frequentada a mesma paisagem. Processos rápidos e fugidios são apreendidos pela 
comparação possibilitada pelos registros e pelos relatos. Distintas "qualidades ambientais" (NORBERG-SCHULZ, 2013) se desdobram num mesmo espaço: desolação e serenidade se sobrepõem ao longo da passagem do tempo. A partir de uma materialidade e de suas forças cambiantes, engendram-se as paisagens do mundo vivido, do imprevisível - do invisível, do efêmero e do intangível (NOGUÉ, 2008).

O que é transitório pode também deixar marcas aparentemente permanentes, que vão se deteriorando num ritmo lento que dificilmente é apreendido no cotidiano: ruínas, processos interrompidos e abandonados. As ruínas banais das paisagens indeterminadas não têm valor histórico, são uma série de "futuros abandonados" (SMITHSON, 2009). Um portal de alvenaria que anuncia a entrada para algum lugar que não existe mais; carcaças de veículos deixadas nas margens do córrego, aguardando alguma atribuição; uma ponte singela que aos poucos vai perdendo seus componentes, primeiro o guarda corpo, depois algumas tábuas, até não permitir mais a conexão das duas margens.

Outras marcas são constituídas por processo inverso e, enquanto ainda fazem parte de uma rotina, são aprofundadas pela insistência do uso (do percurso). Trilhas atravessam as paisagens indeterminadas e tornam concretamente apreensível a ausência de quem passou e indicam a possibilidade de quem ainda passará.

Conforme se dá a aproximação com as paisagens indeterminadas, vai se revelando sua variedade de cores, texturas, formas passageiras. Elementos que são desconsiderados pelo olhar estético de uma cultura dominante, mas que chamam a atenção, mesmo de maneira imperceptível: um terreno baldio coberto de flores alaranjadas em conjunto com um capim rosado; a variedade de folhas de distintos verdes e tamanhos ao longo das margens esquecidas do córrego.

A uma visão tão próxima dessas paisagens, que detecta seus detalhes, pode-se contrapor um afastamento, porém, permitindo um olhar que abarque um entorno, um contexto. É um olhar parcialmente distanciado, pois ao mesmo tempo está inserido no mundo vivido. E assim, compreende-se que aquela paisagem depende de um quadro anterior e amplo, de uma base material pré-existente, de um tempo geológico (SMITHSON, 2009) e de um espaço telúrico (DARDEL, 2011). Essa base foi moldada, cortada, desmontada, rearranjada. Mas sua essência 
permanece e sua existência independe do desejo humano. Ela permanece em contínua transformação.

Do alto de uma cumeada, é possível vislumbrar uma paisagem composta pela ondulação da base préexistente, relevo sulcado pelo vale por onde corre o Monjolinho. A superfície rugosa ora oculta ora revela uma massa verde, um conjunto de edifícios. Essa perspectiva explicita a fragilidade da ação humana, cujas ruas ortogonais se transformam em cordas sinuosas que sobem e descem o território.

Esse modo de apreender a paisagem instiga a explorar suas dobras, os horizontes sucessivos (STRAUS, 2000). Ela motiva o deslocamento, estabelecendo um próximo e um distante (CERTEAU, 2007; DARDEL, 2011; CULLEN, 2002).

E continuamente, num movimento que intercala aproximação e afastamento, as paisagens determinadas e indeterminadas se mostram presentes em suas relações dialéticas e em suas singularidades. Depois de conhecer as paisagens do Monjolinho, não é mais possível concebê-lo como córrego genérico. Suas potencialidades são reveladas como manifestações possíveis ou desejadas como paisagem. 


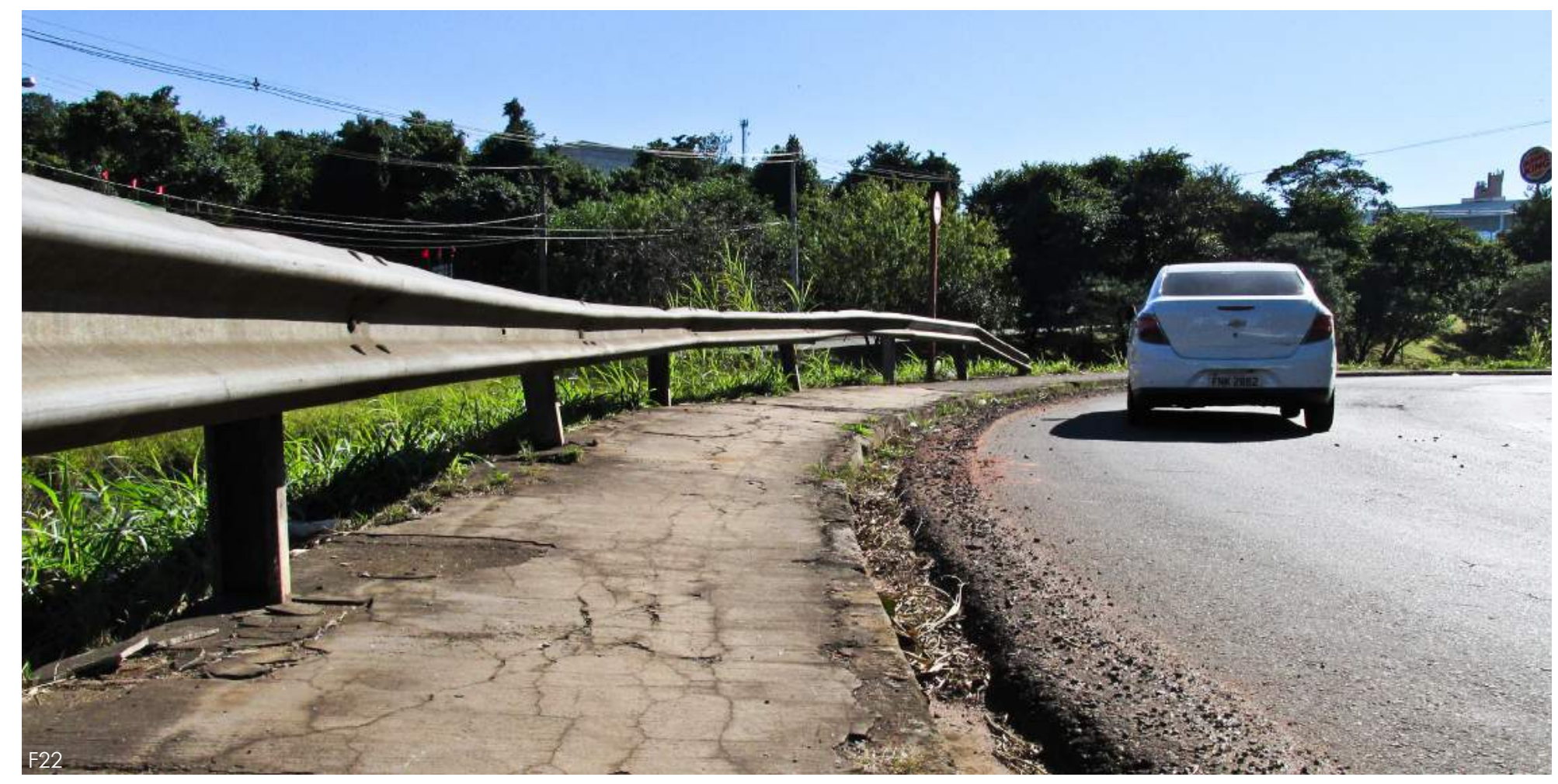



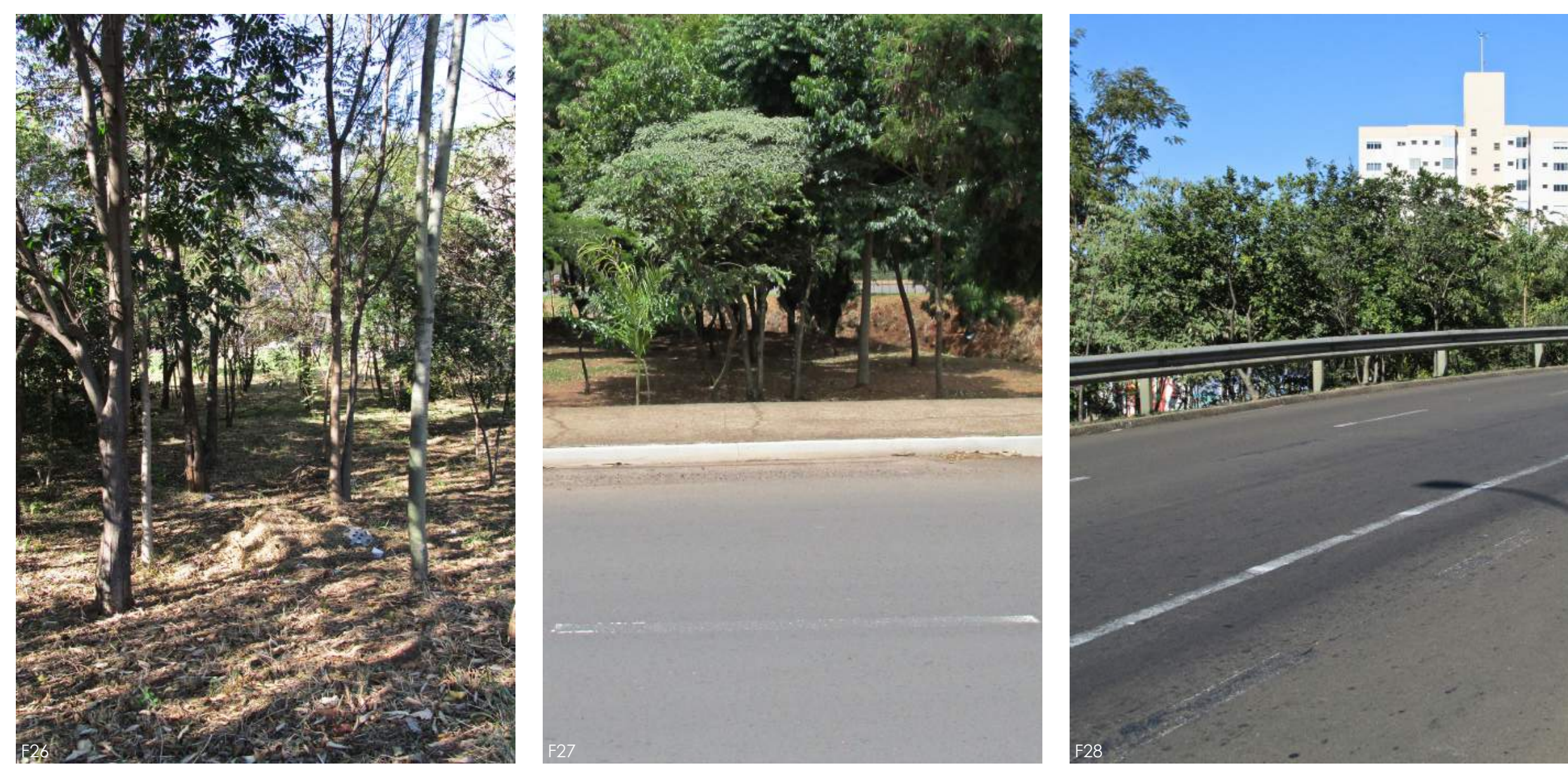


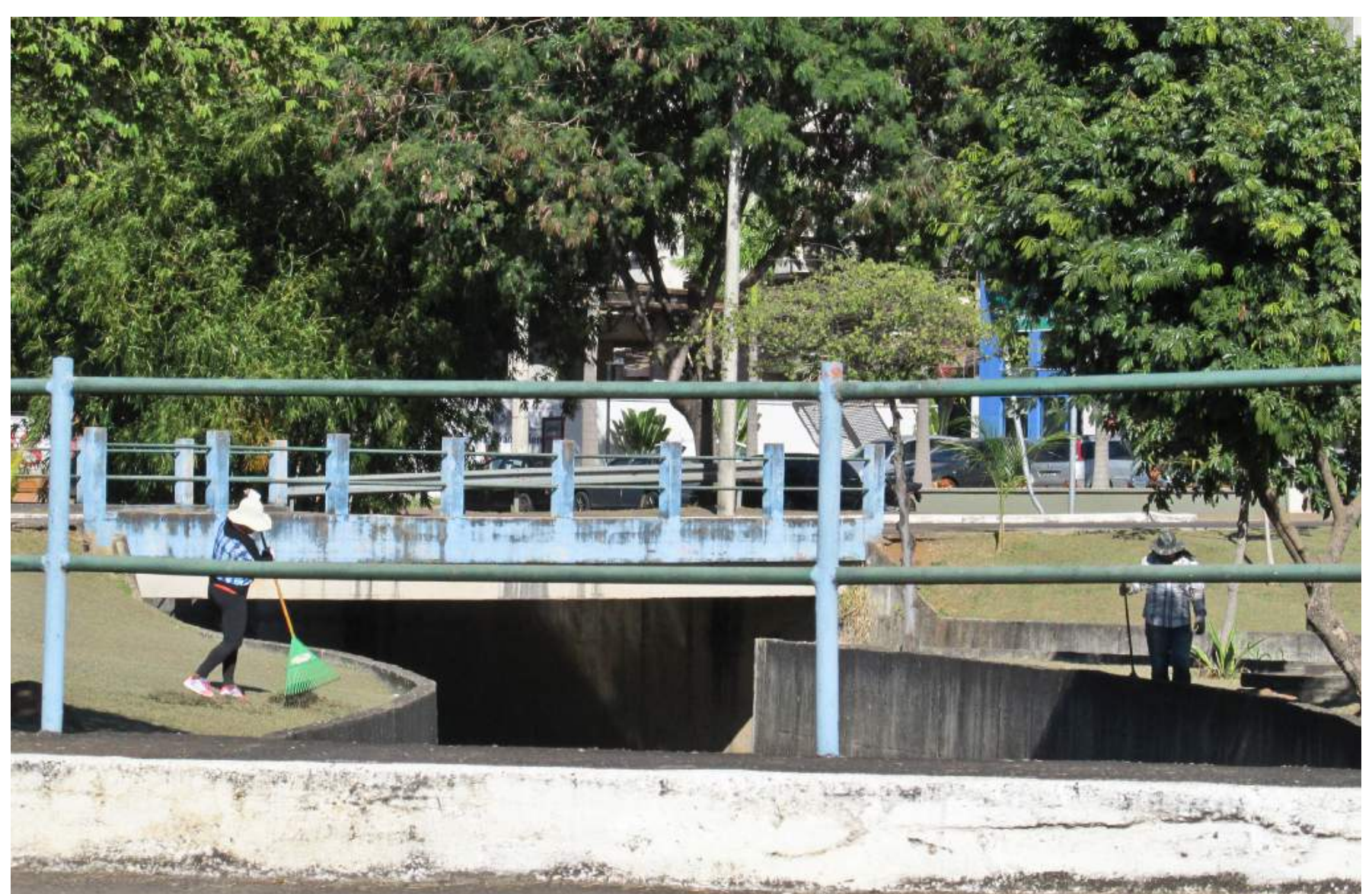




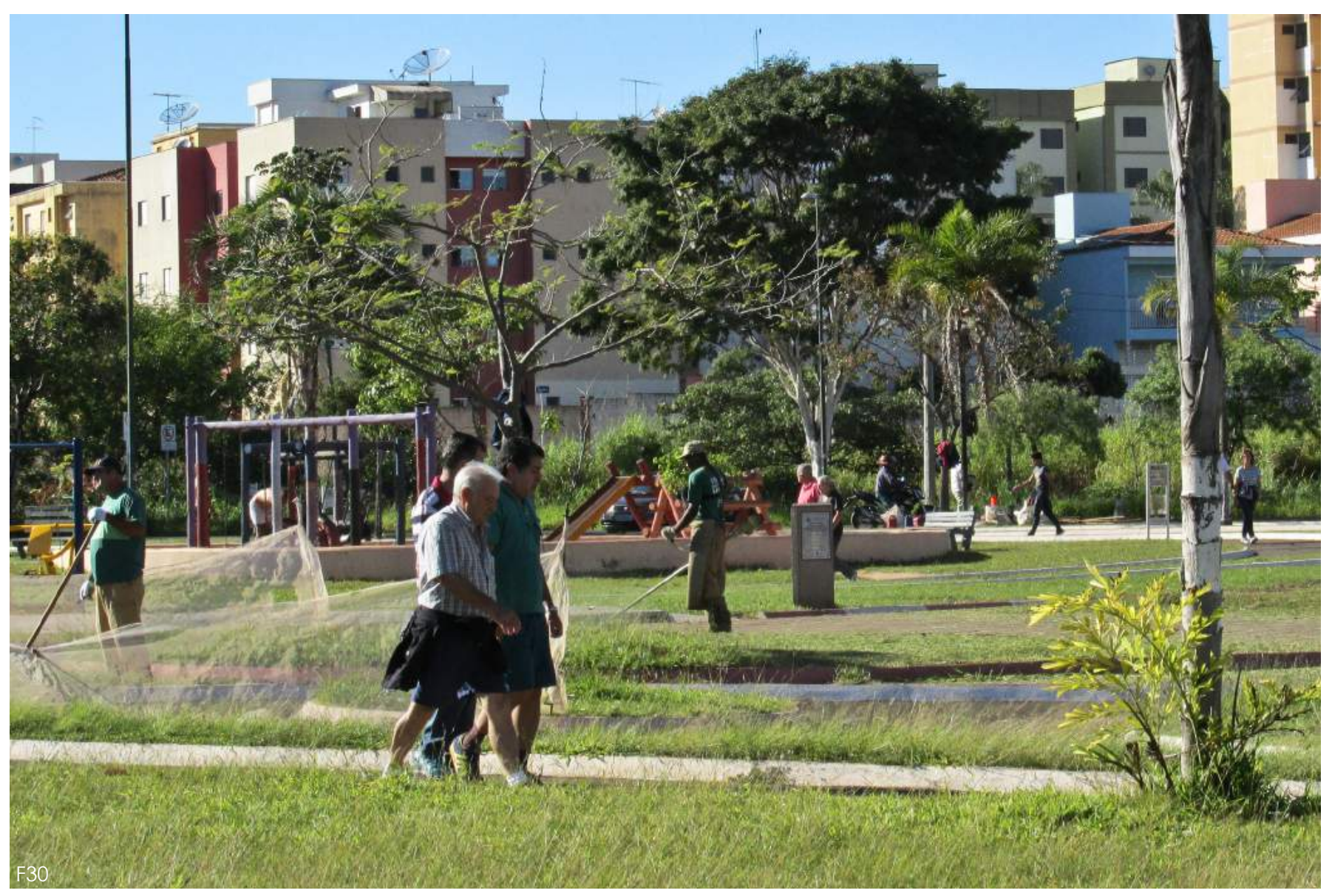



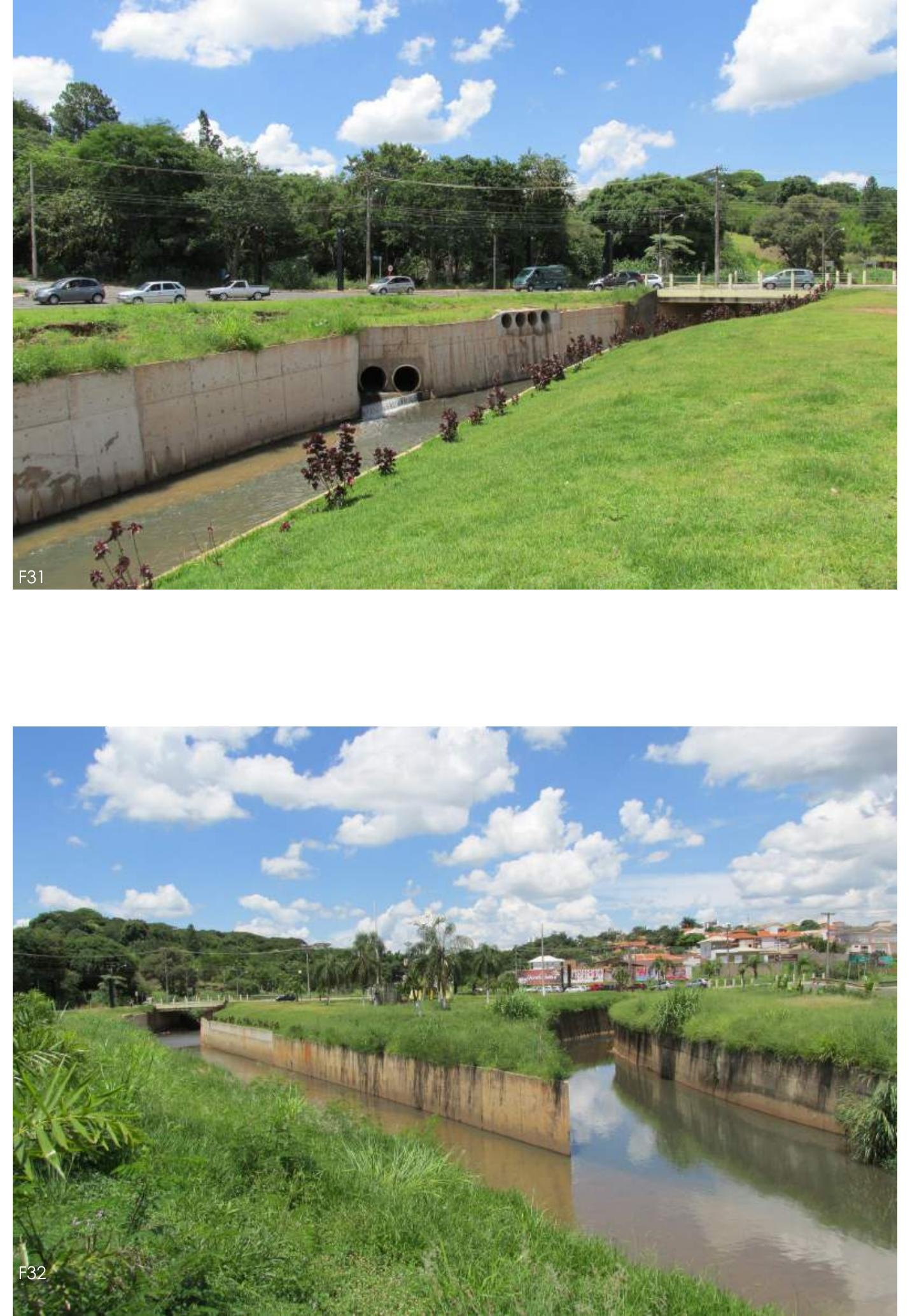
F33: rotatória Antônio Adolpho Lobbe ou Rotatória do Cristo. Fonte: LIMA, Maria Cecília P. B. de, 2017.

F34: enchente na Rotatória do Cristo em 2015

Fonte: São Carlos Urgente, 2015.
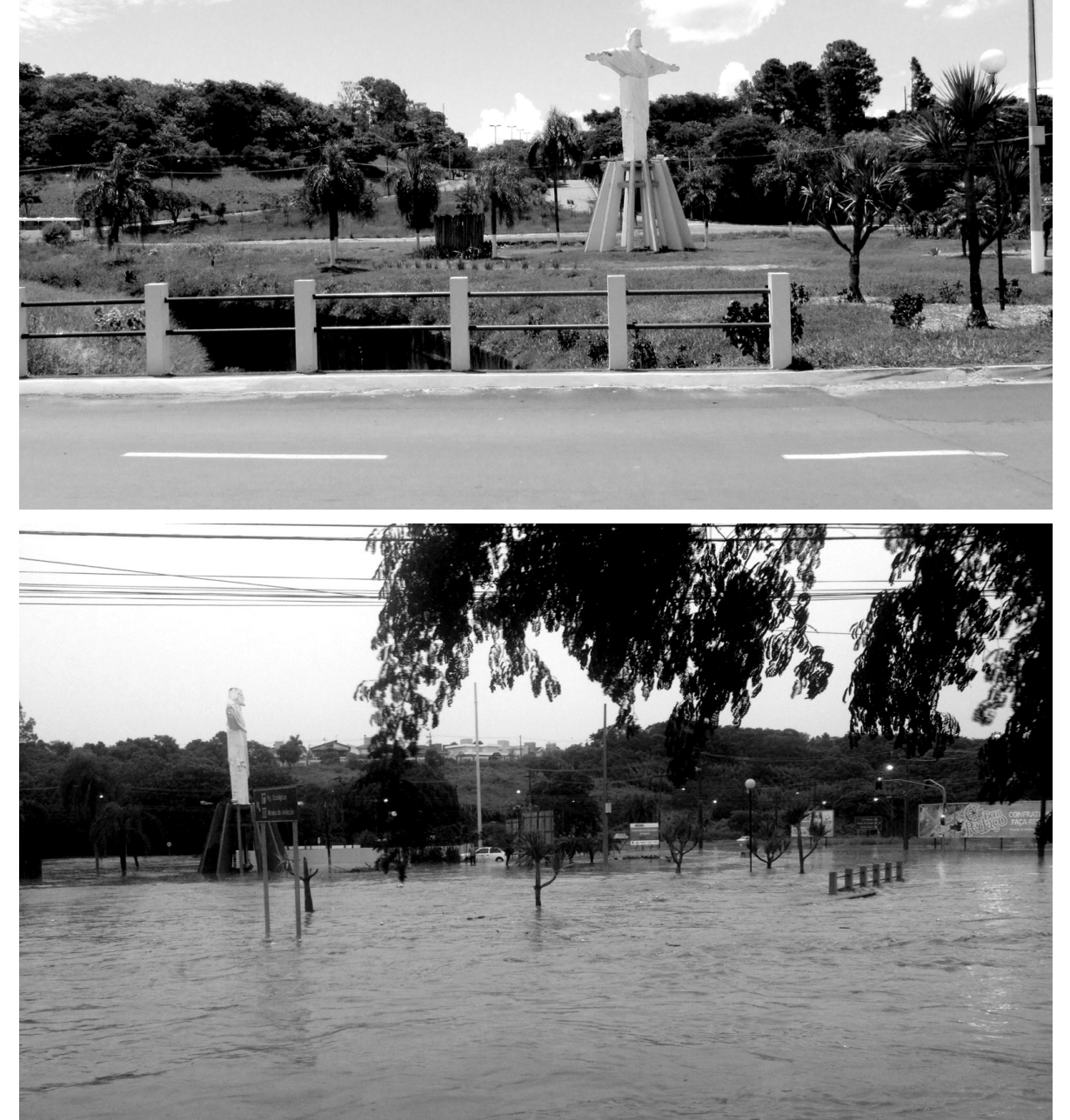

F35: enchente na Rotatória do Cristo em 1999 Fonte: acervo da Fundação Pró-Memória de São Carlos, 1999.

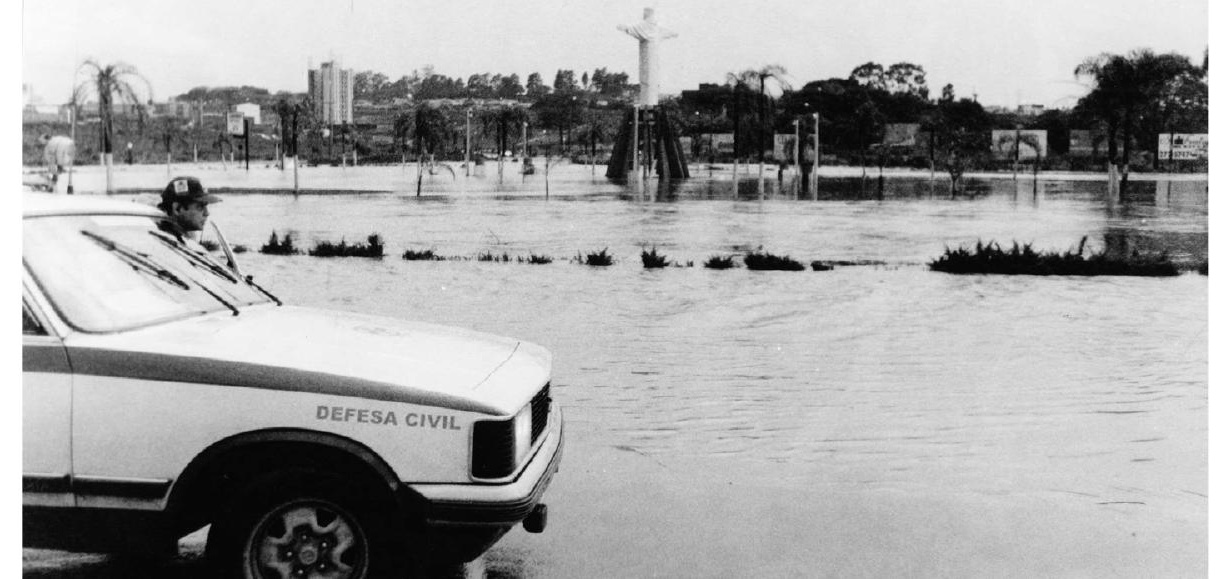


As paisagens determinadas que funcionam são aquelas que cumprem a função para a qual foram projetadas e construídas.

F36: alguns espaços livres que cumprem a função projetada.

Fonte: elaborado a partir de imagem do Google Earth. 


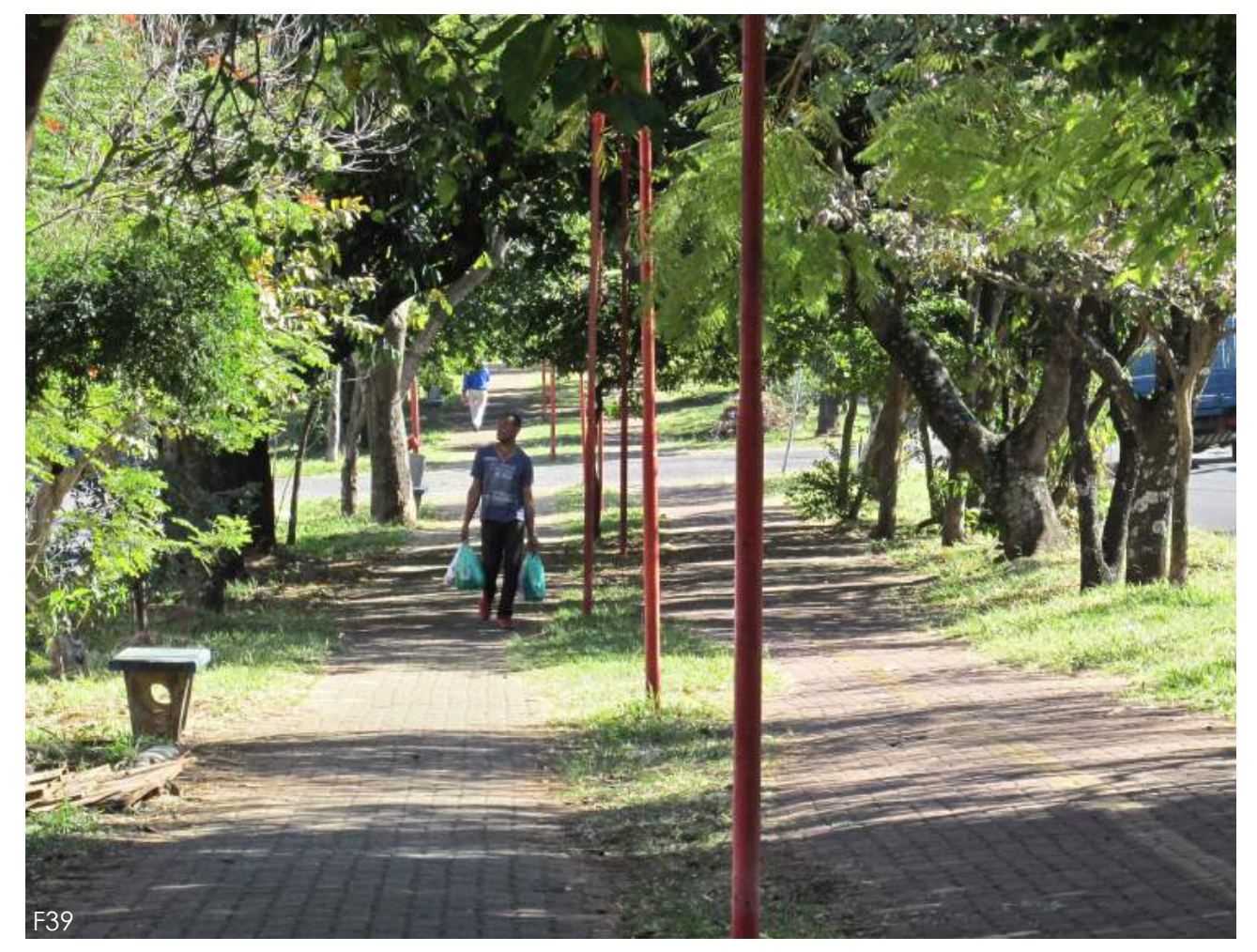

3 Parque Linear das Torres (nas proximidades dos córregos Medeiros e Monjolinho).

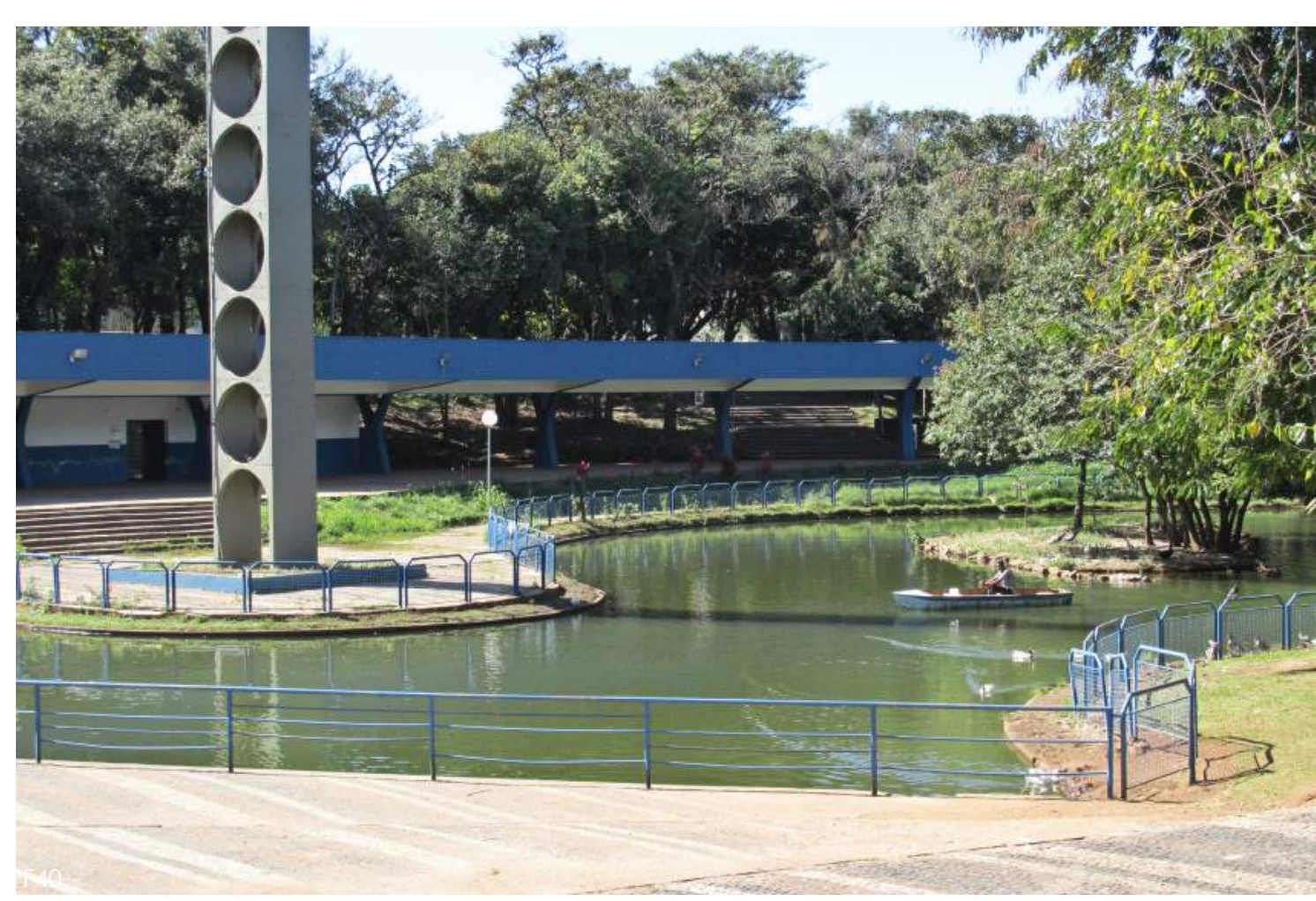

4 Parque do Bicão (na nascente do córrego Medeiros). 

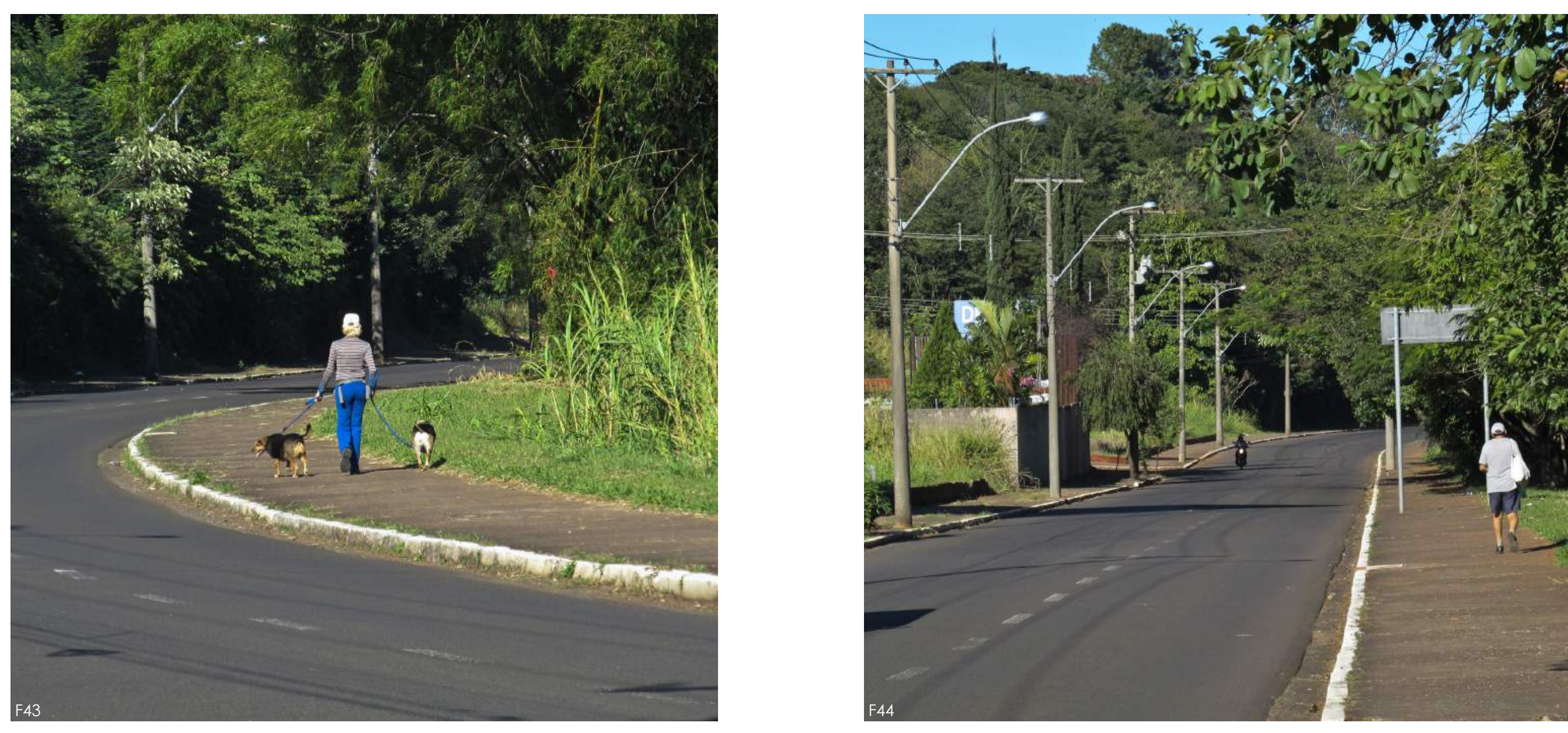
As intenções fracassadas de projeto são reveladas pela presença de totens informativos abandonados, equipamentos de playground deteriorados, desenhos de piso com falhas. Os potenciais usuários desses espaços não se fazem presentes e essa paisagem é tomada pela indeterminação.

F45: alguns espaços livres que não cumprem a função projetada.

Fonte: elaborado a partir de imagem do Google Earth. 







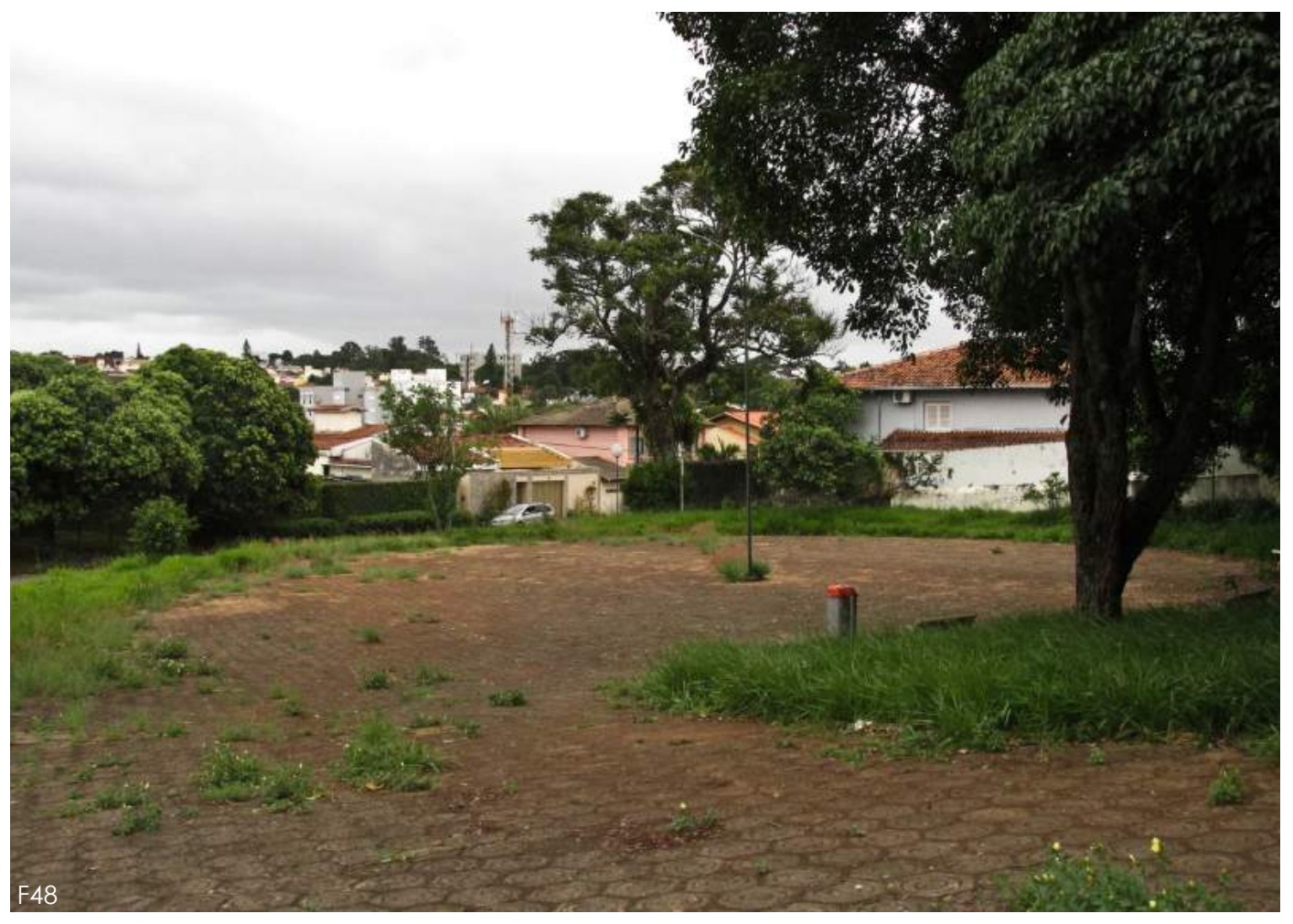

3 Praça Prof. Miguel Carlos Stamato (nas proximidades do córrego Monjolinho)

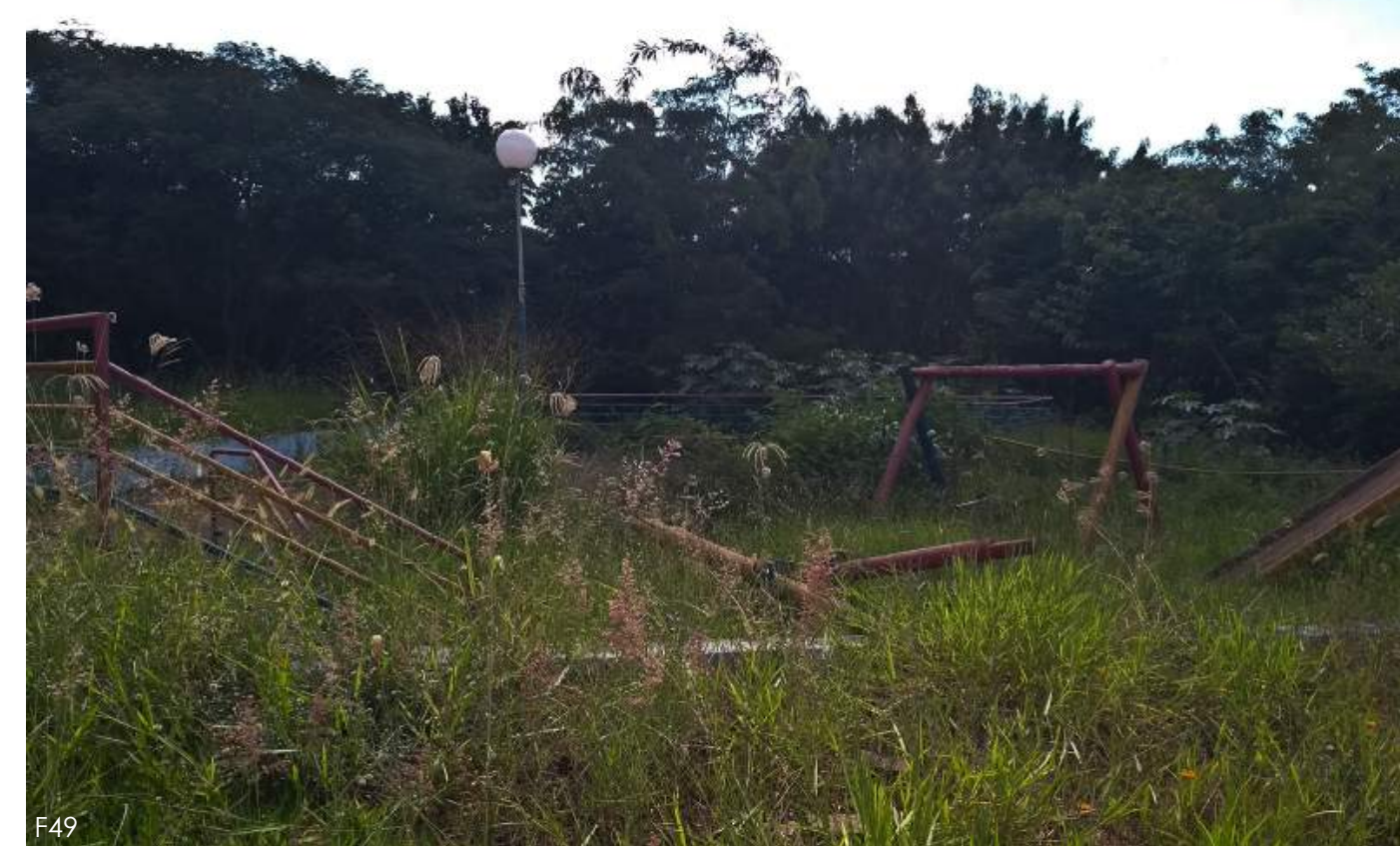

4 Praça sem nome (nas proximidades do córrego Monjolinho) 
Abandonar:

Retirar-se de um lugar, ir embora; partir, sair. Deixar ao abandono, não dar mais atenção ou proteção; desamparar Desistir de; desinteressar-se de; deixar de lado, renunciar a Deixar-se vencer por; entregar-se, render-se Deixar ou fazer ficar solto e relaxado; afrouxar

(Dicionário Michaelis On-line, 2019) 


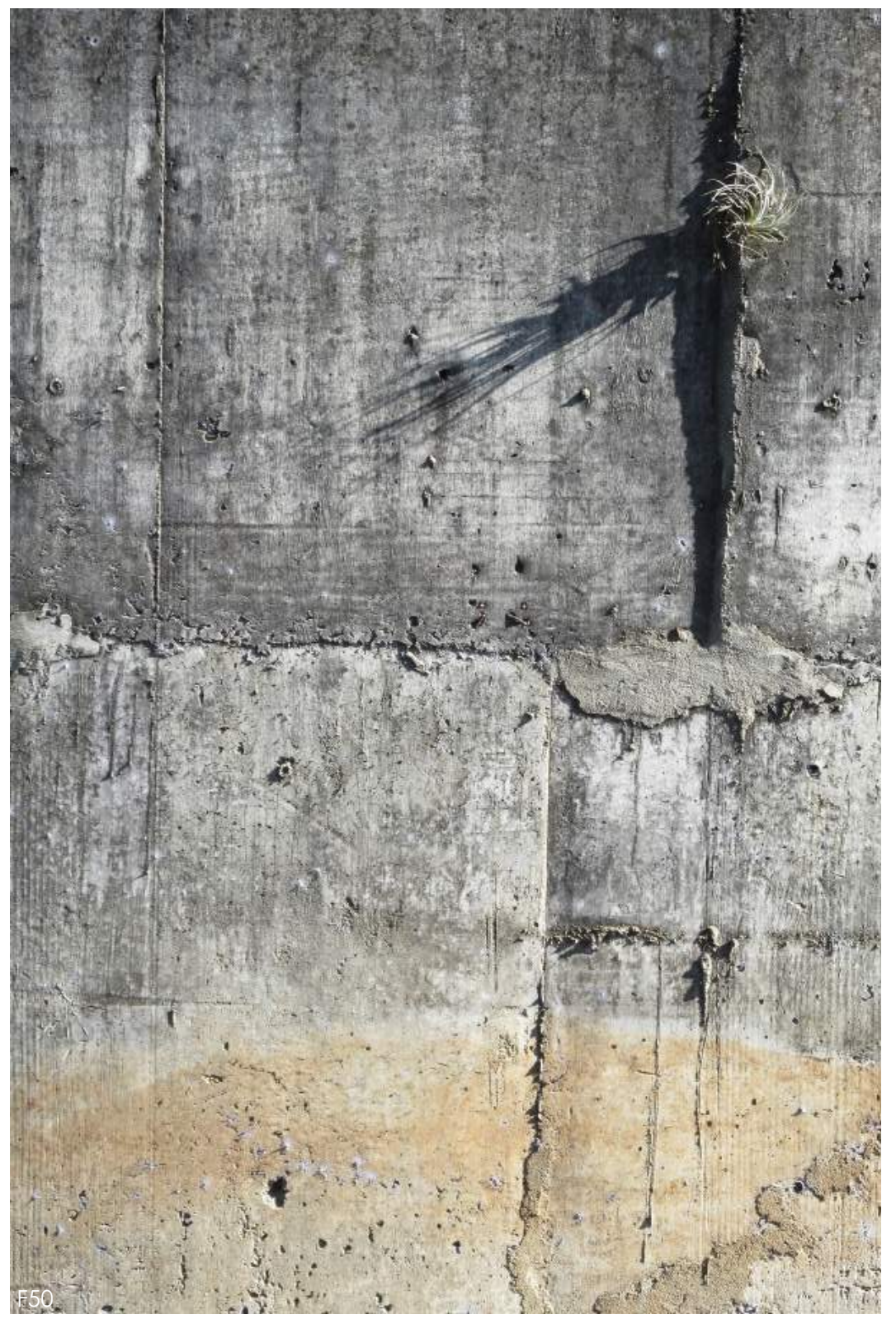



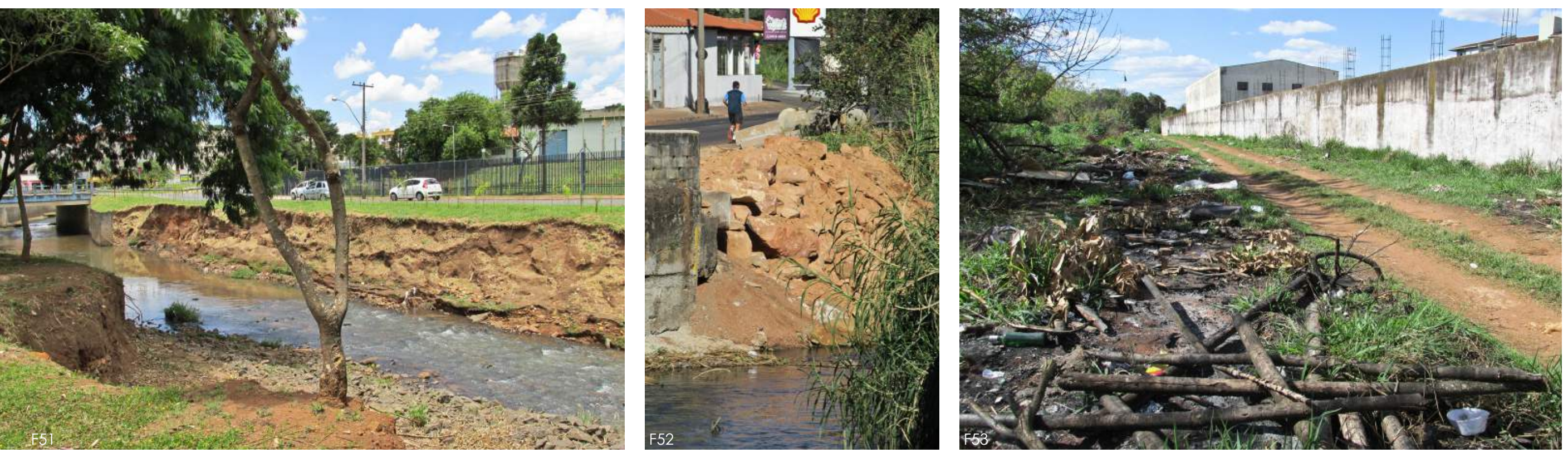

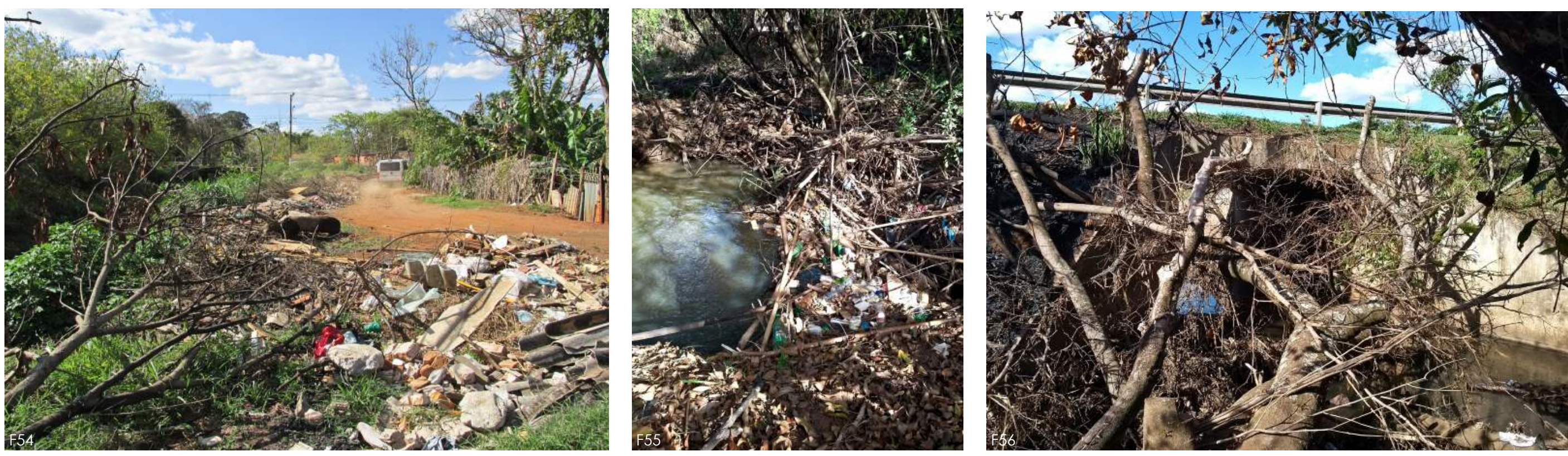

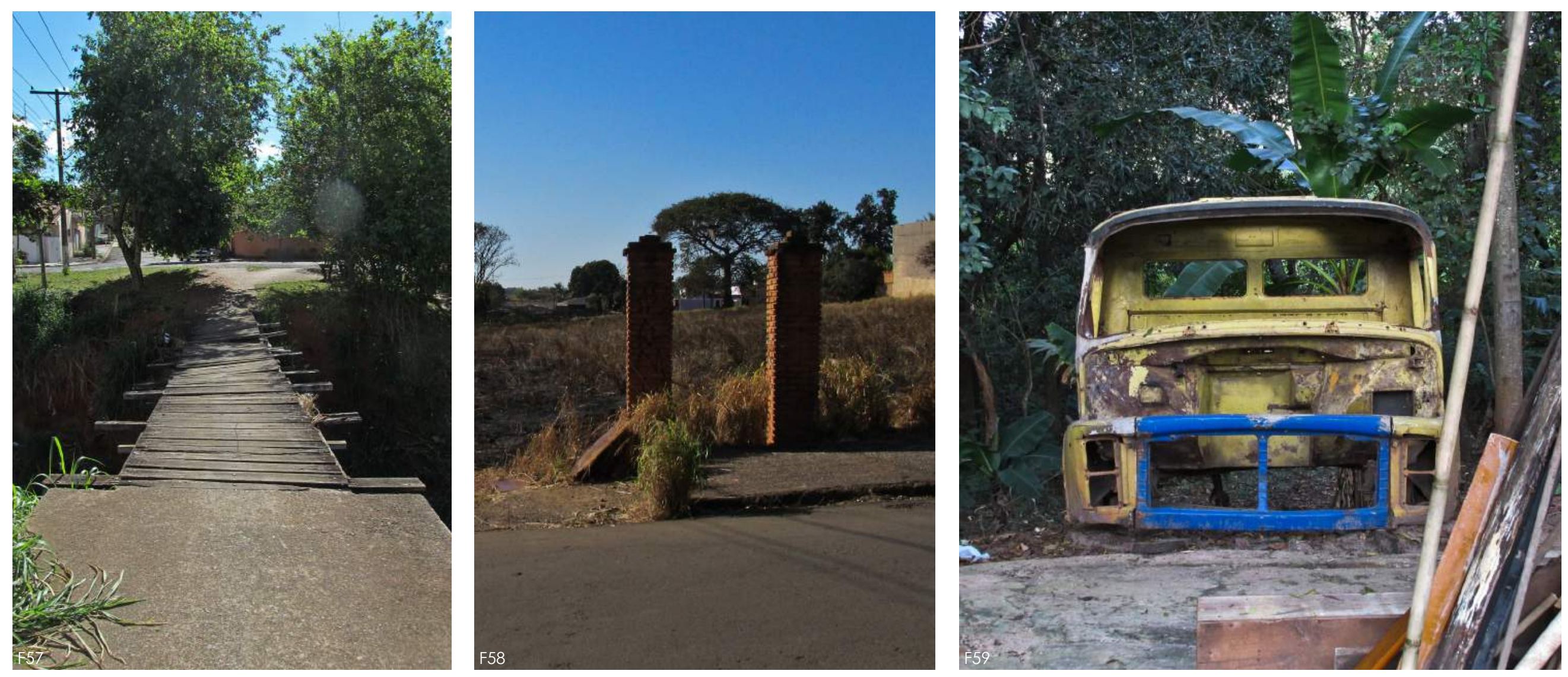

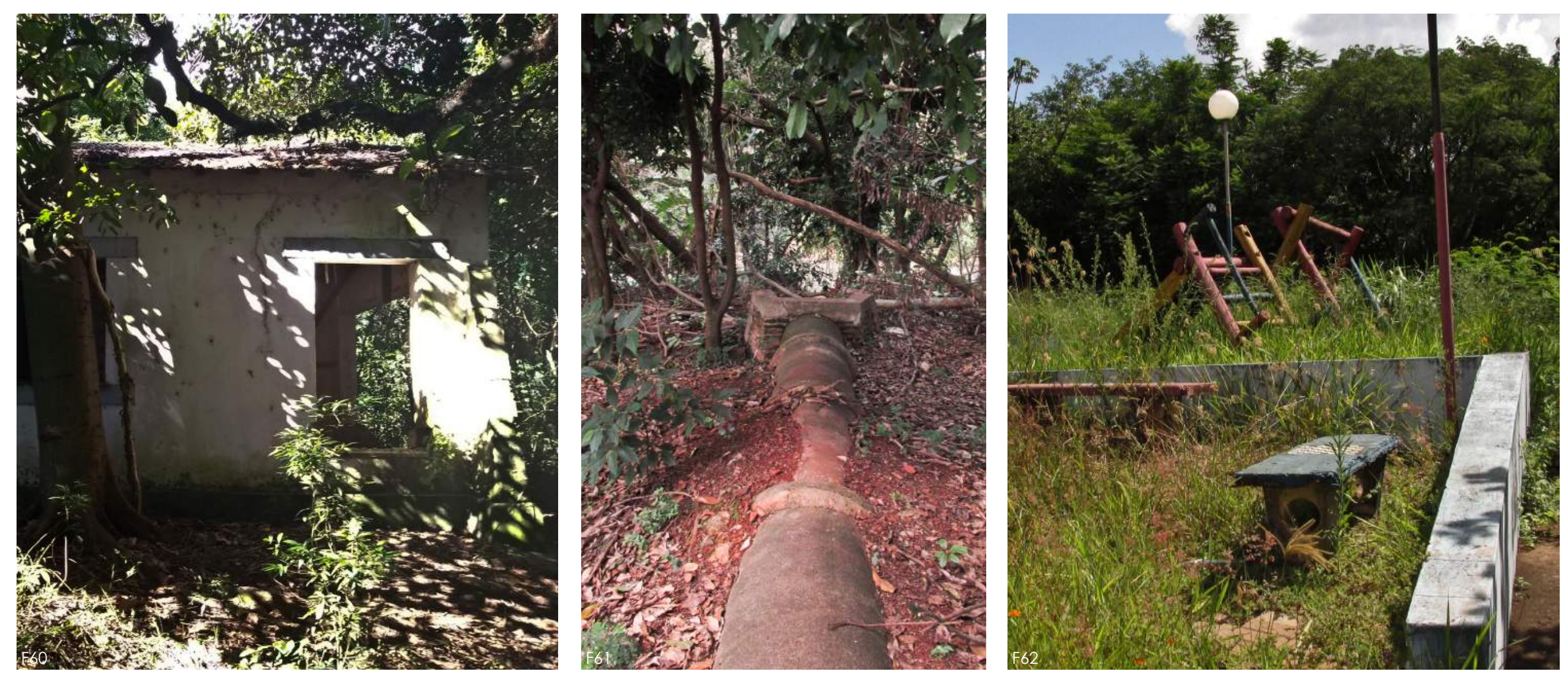

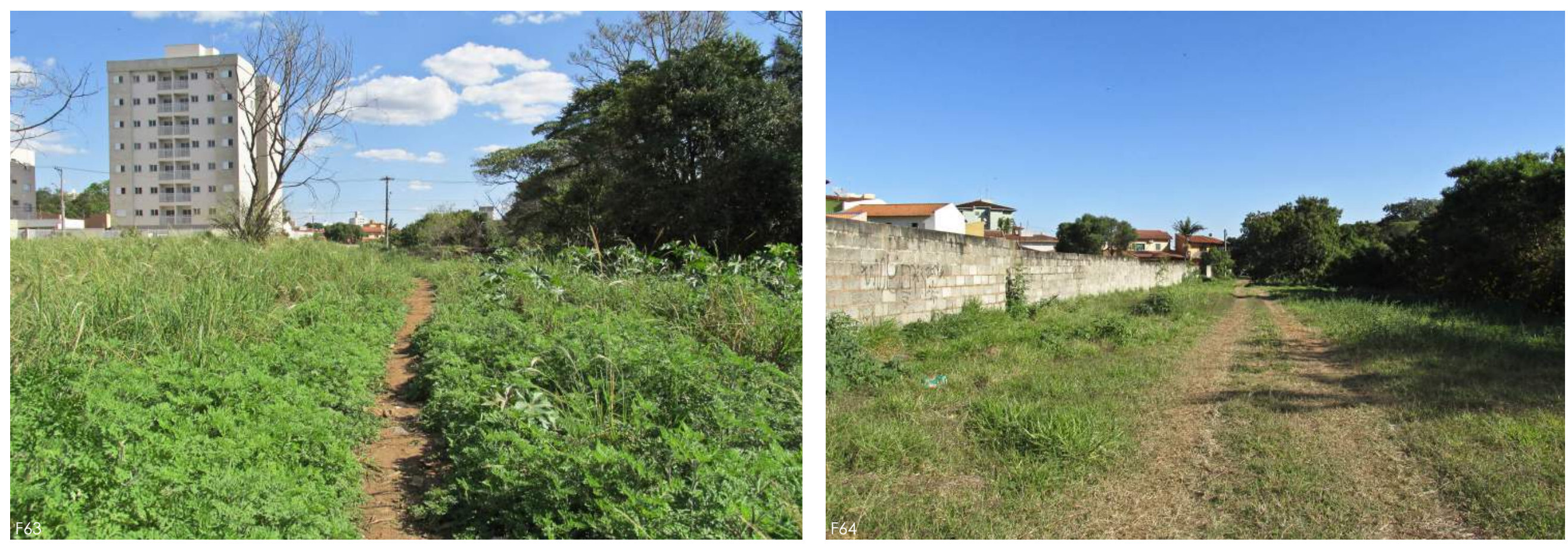

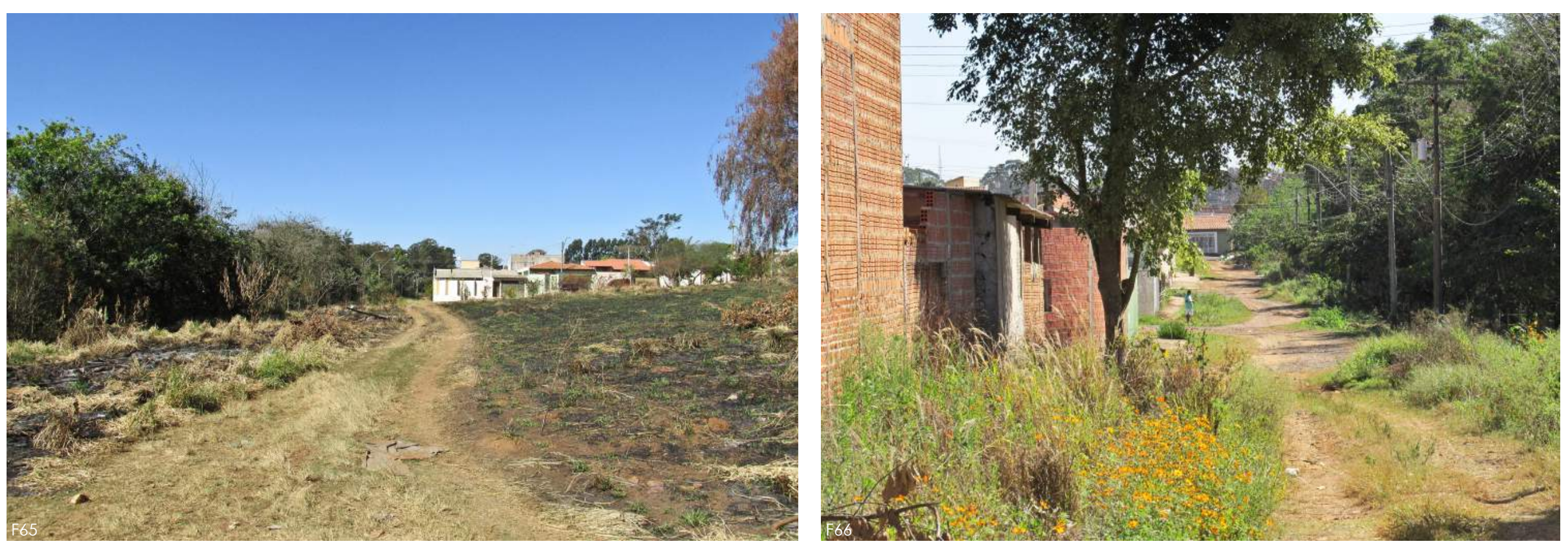

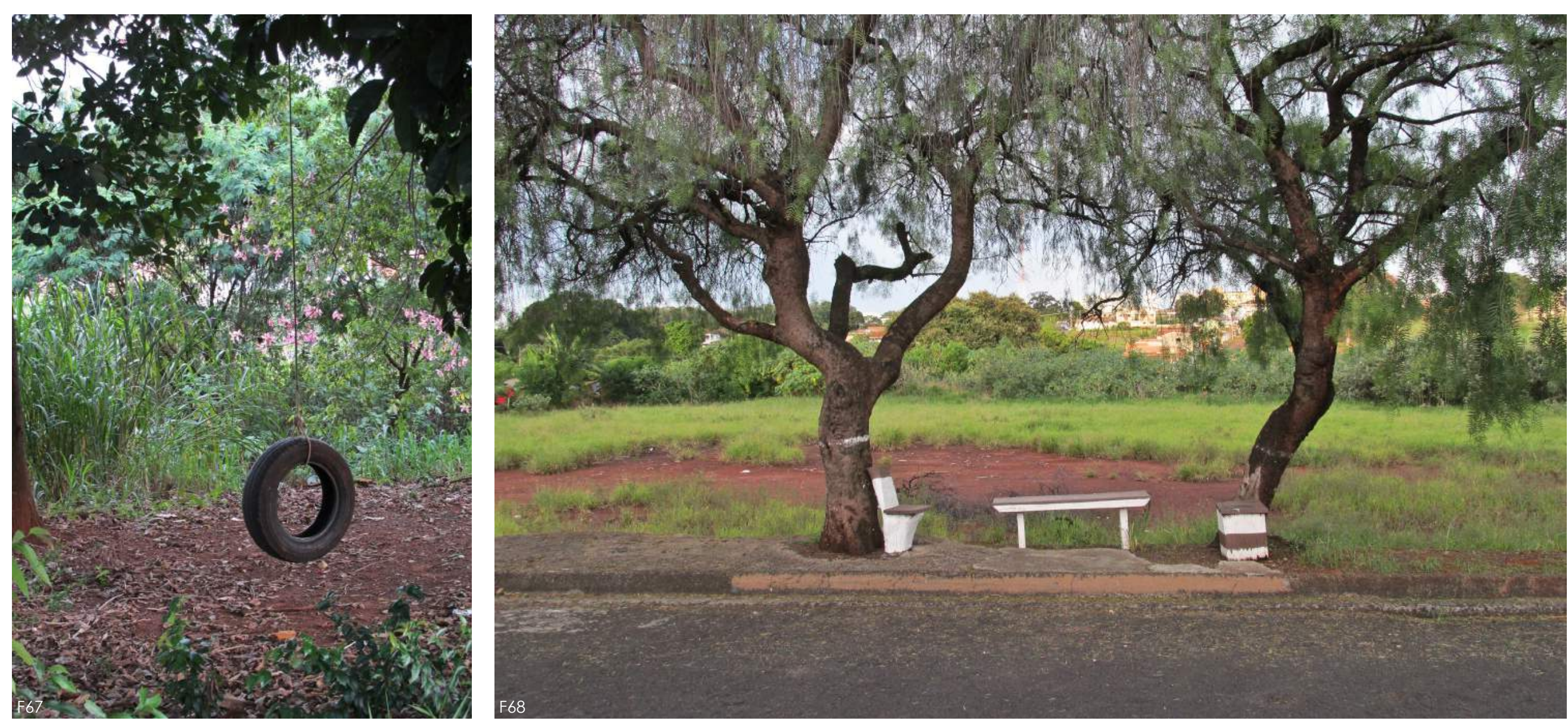

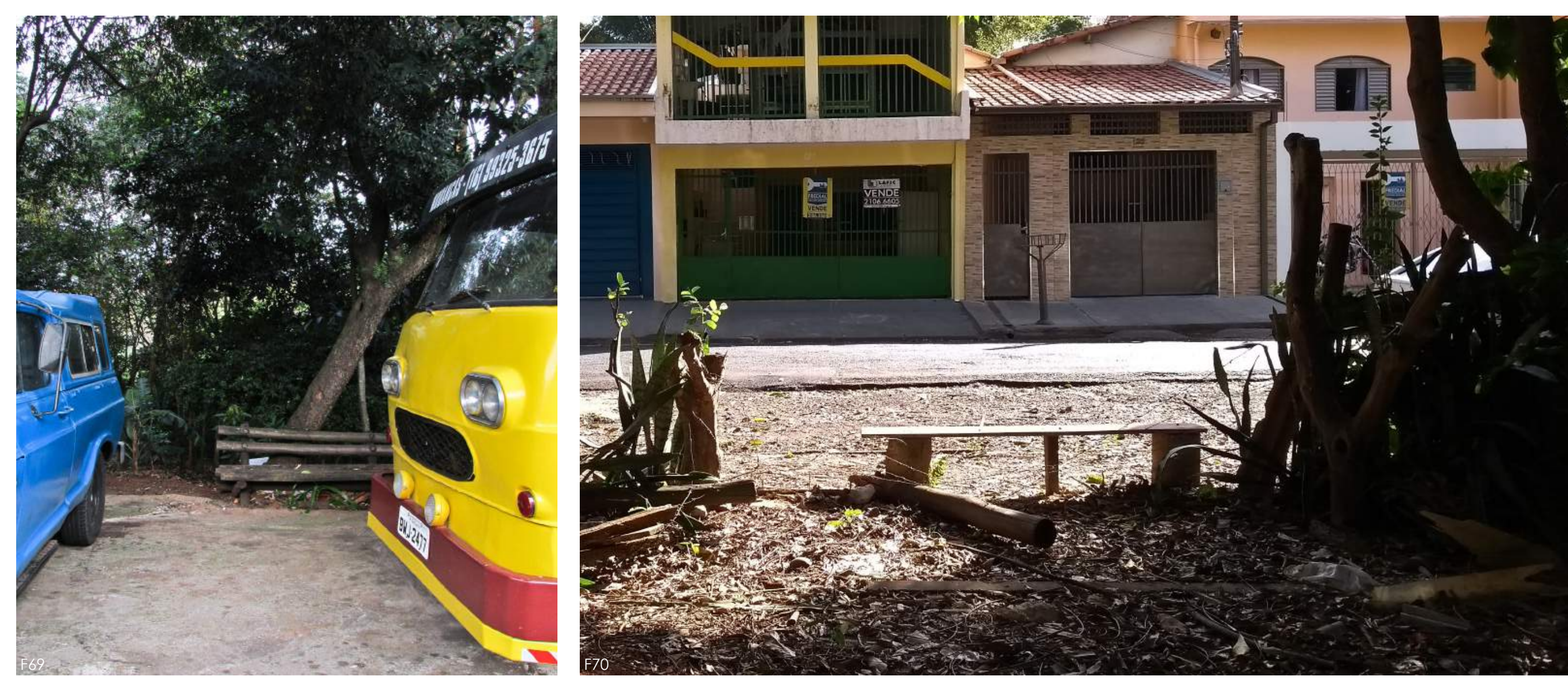

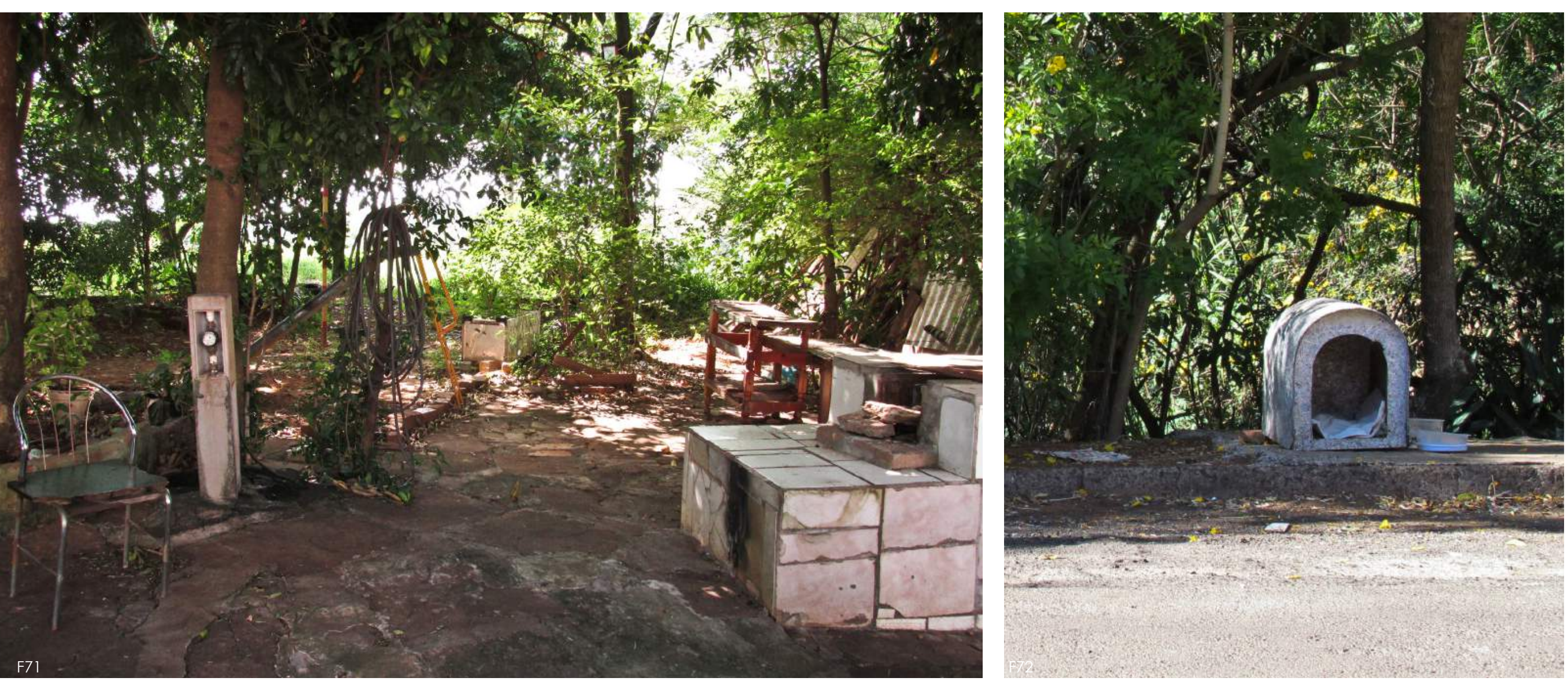

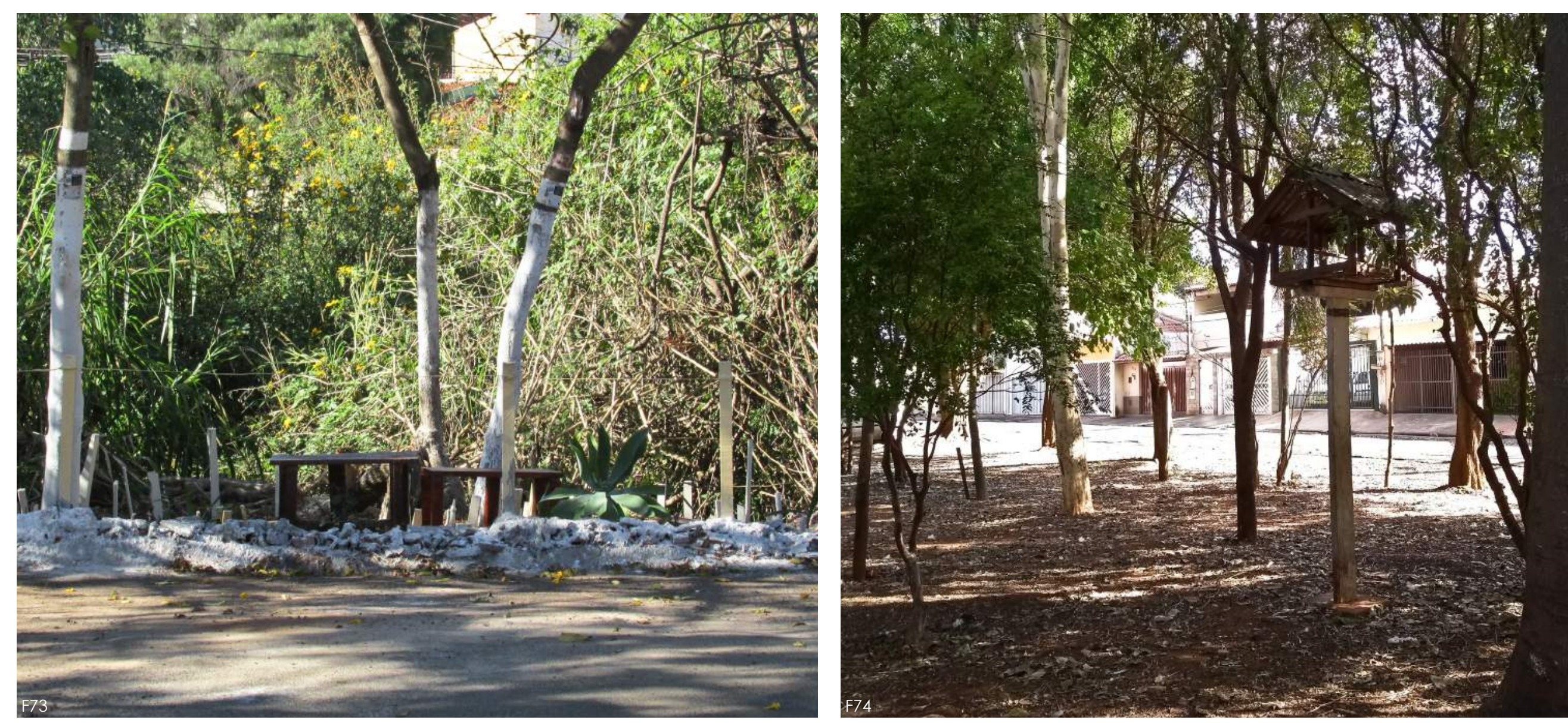

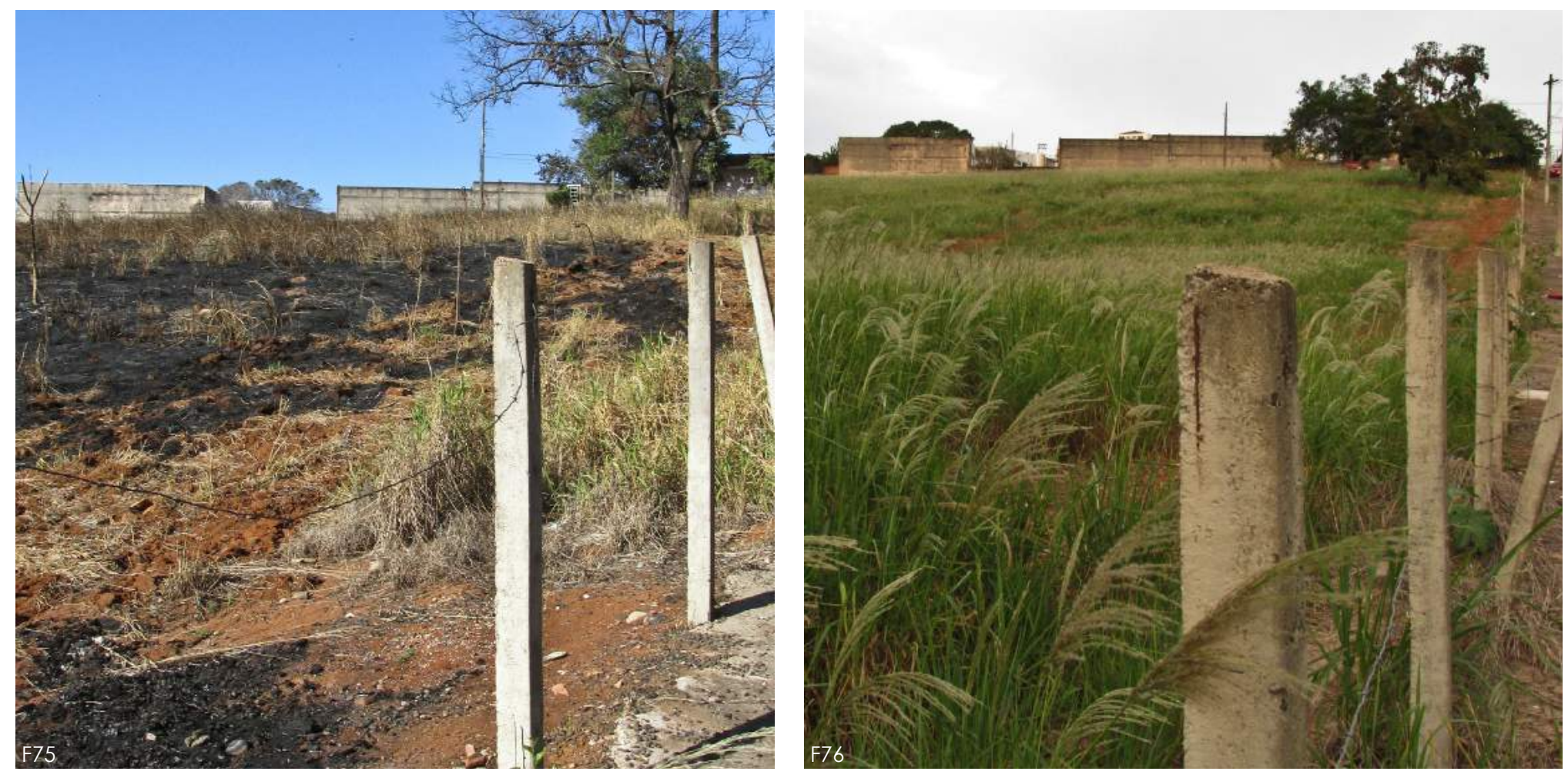


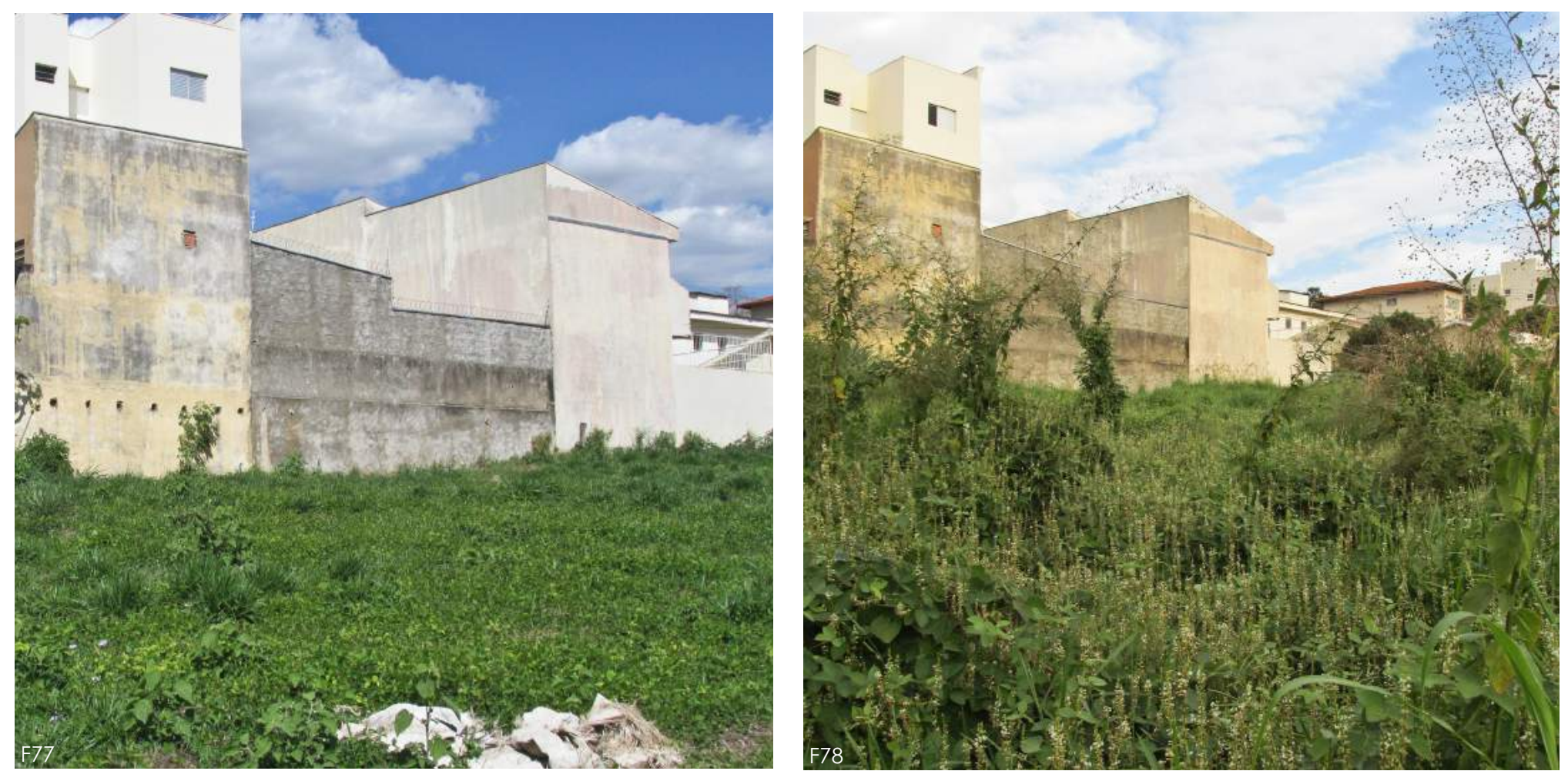



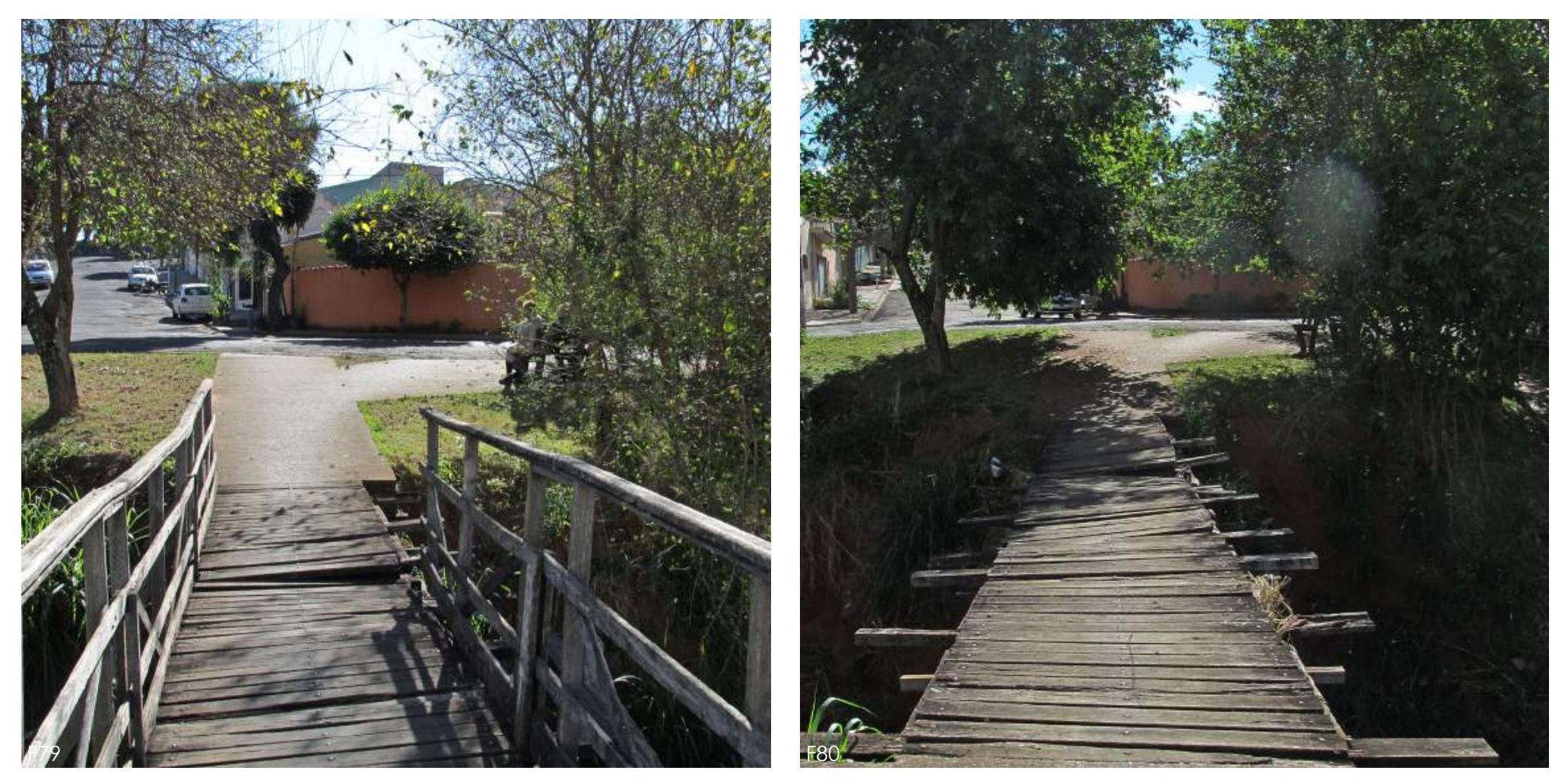


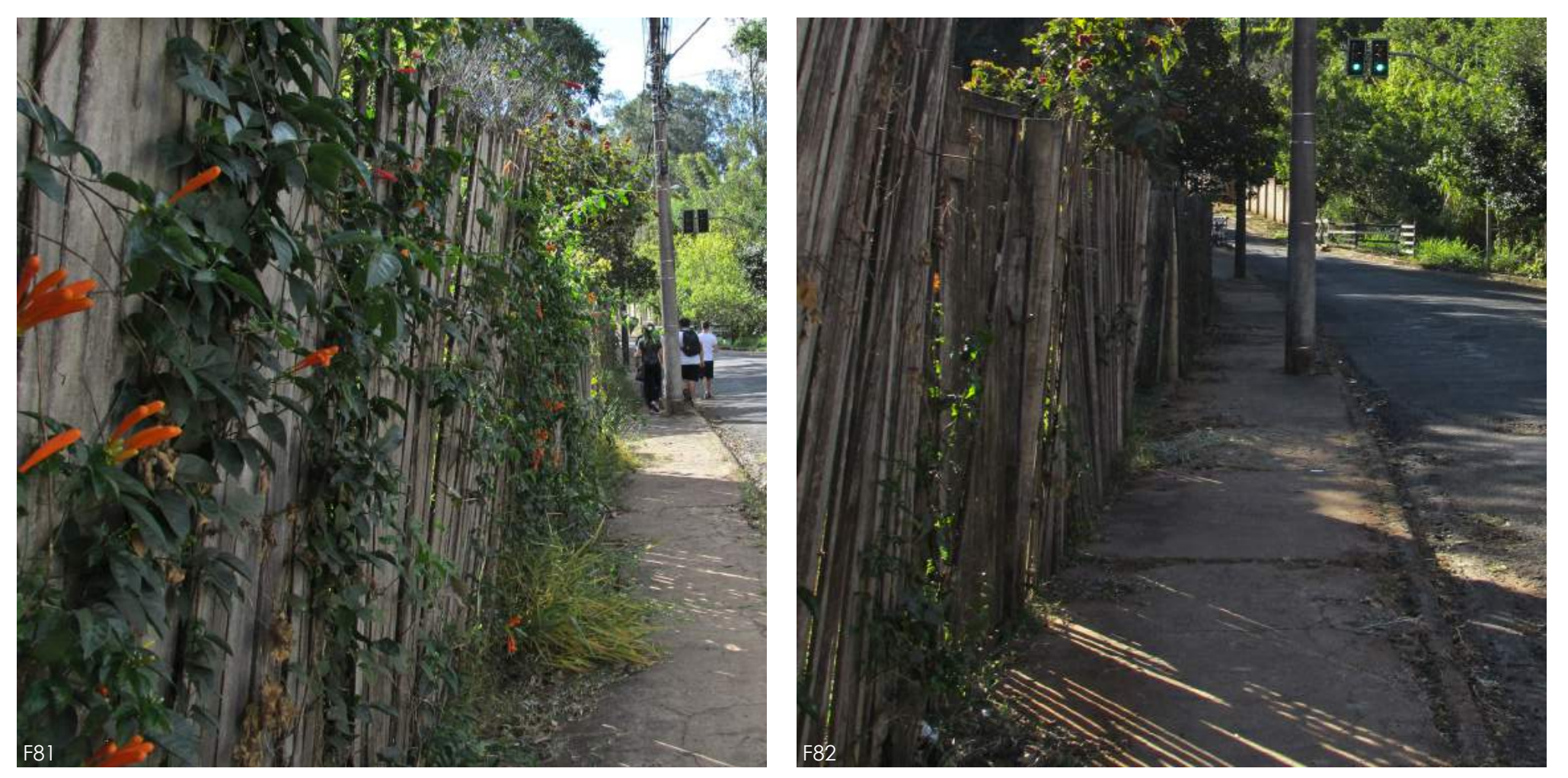



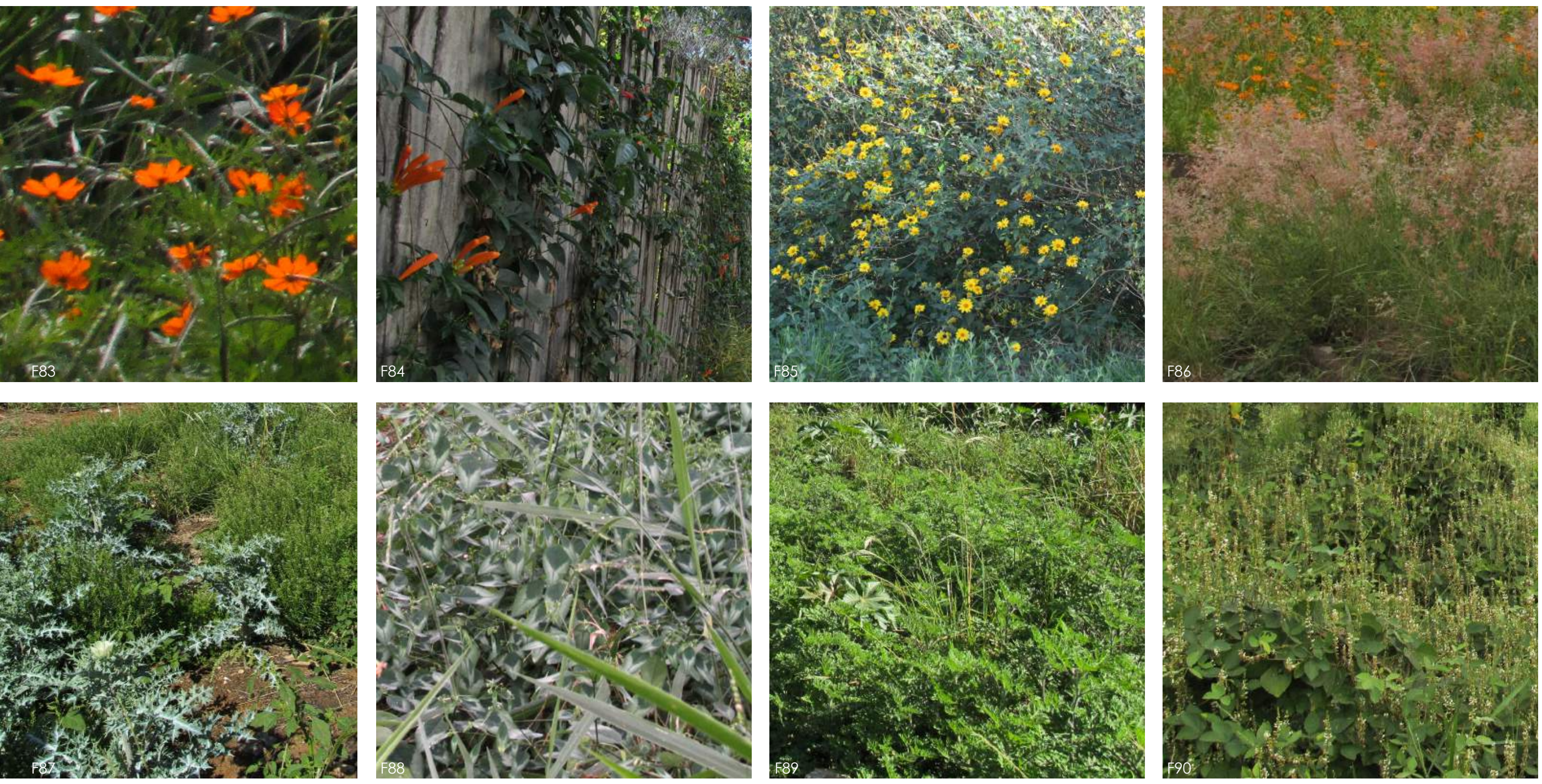

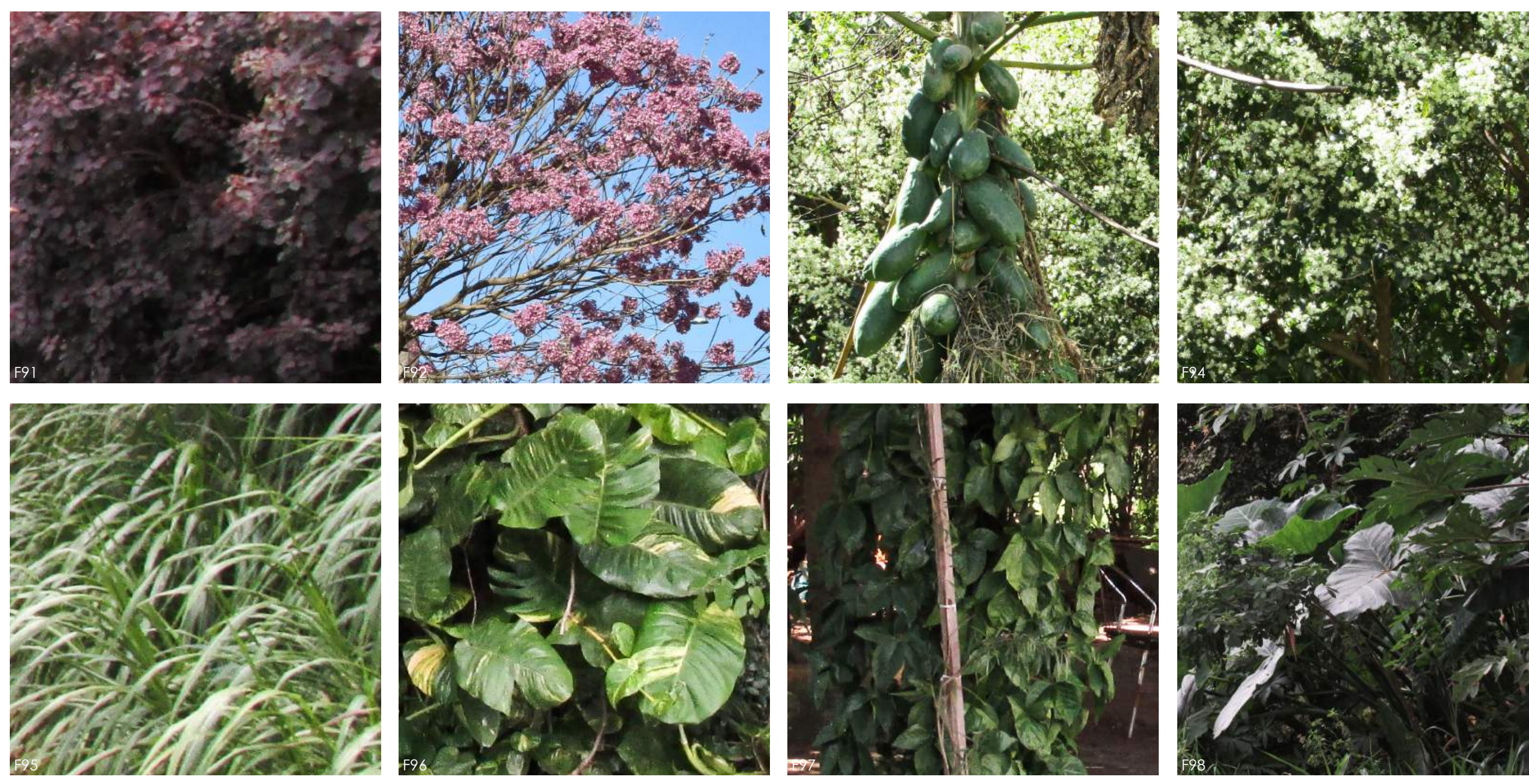
"[O rio] Ao fluir, seu percurso vai riscando linhas na paisagem, como um pincel de água desenhando meandros, arcos e curvas. O rio traz o sentido de uma maleabilidade primordial no desenho da paisagem

(COSTA, 2006, p. 11). 


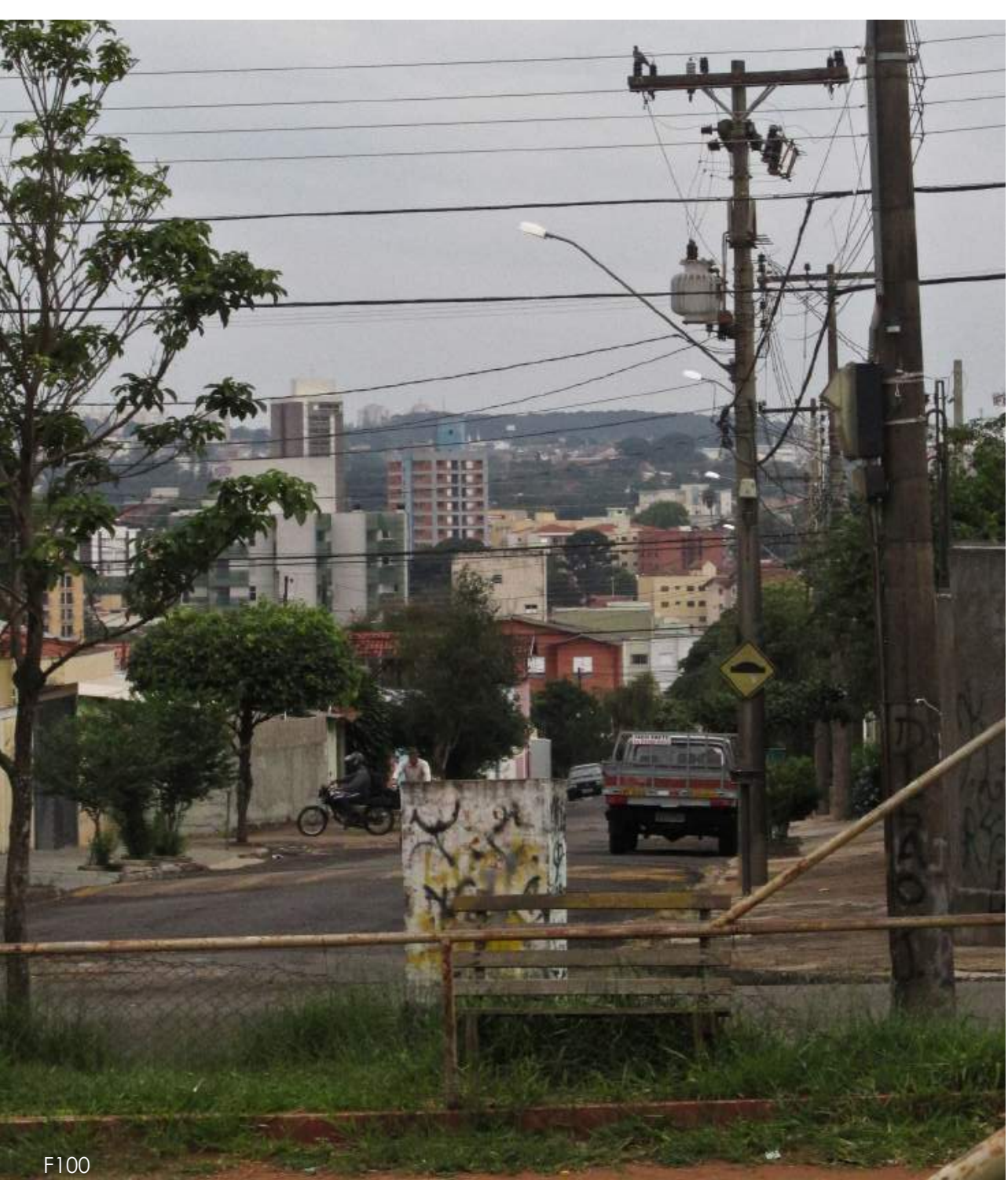

1 Vista a partir da Praça Vereador Lucas Perroni Junior

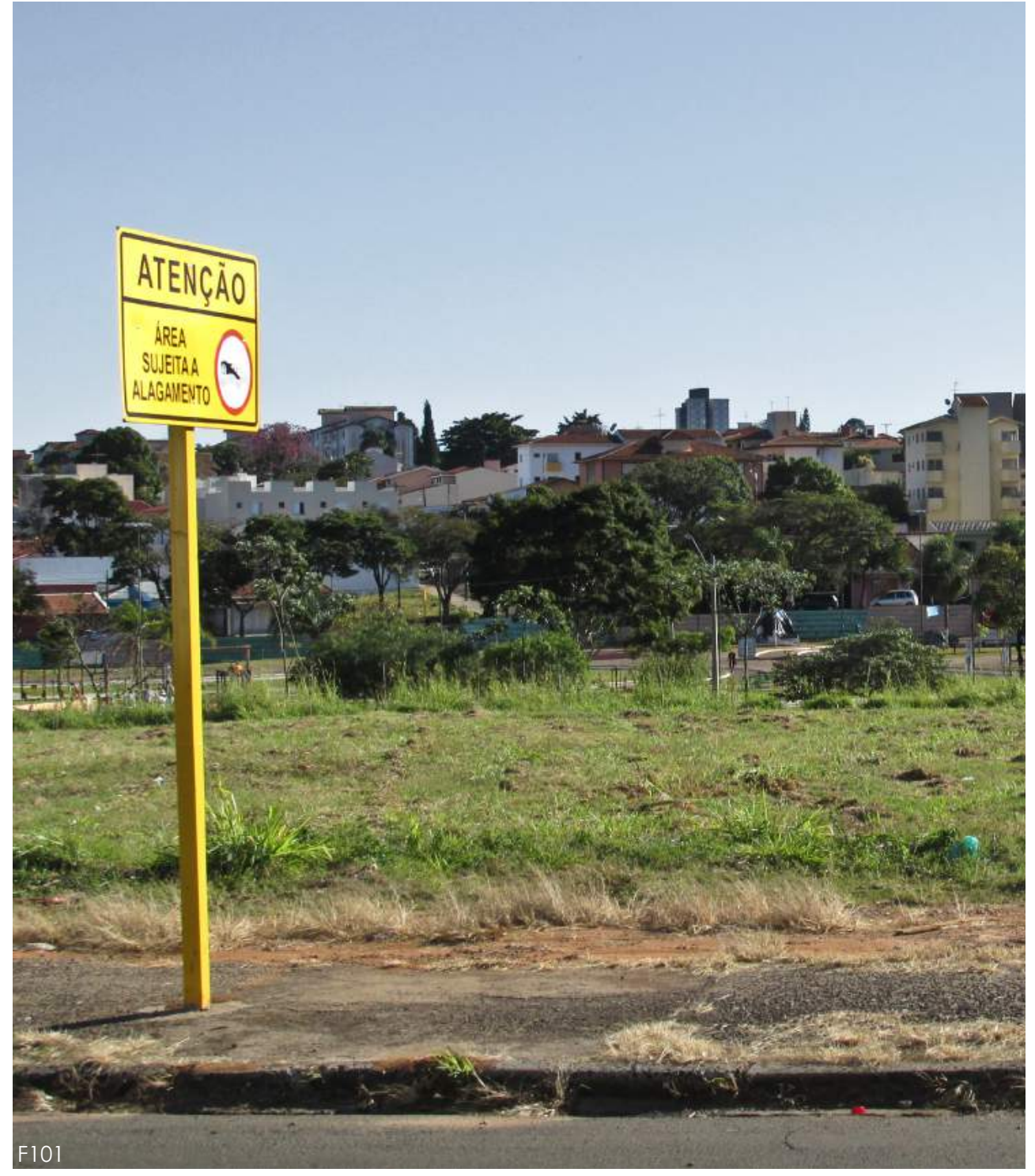

2 Vista a partir de espaço livre público em frente ao Parque do Kartódromo 


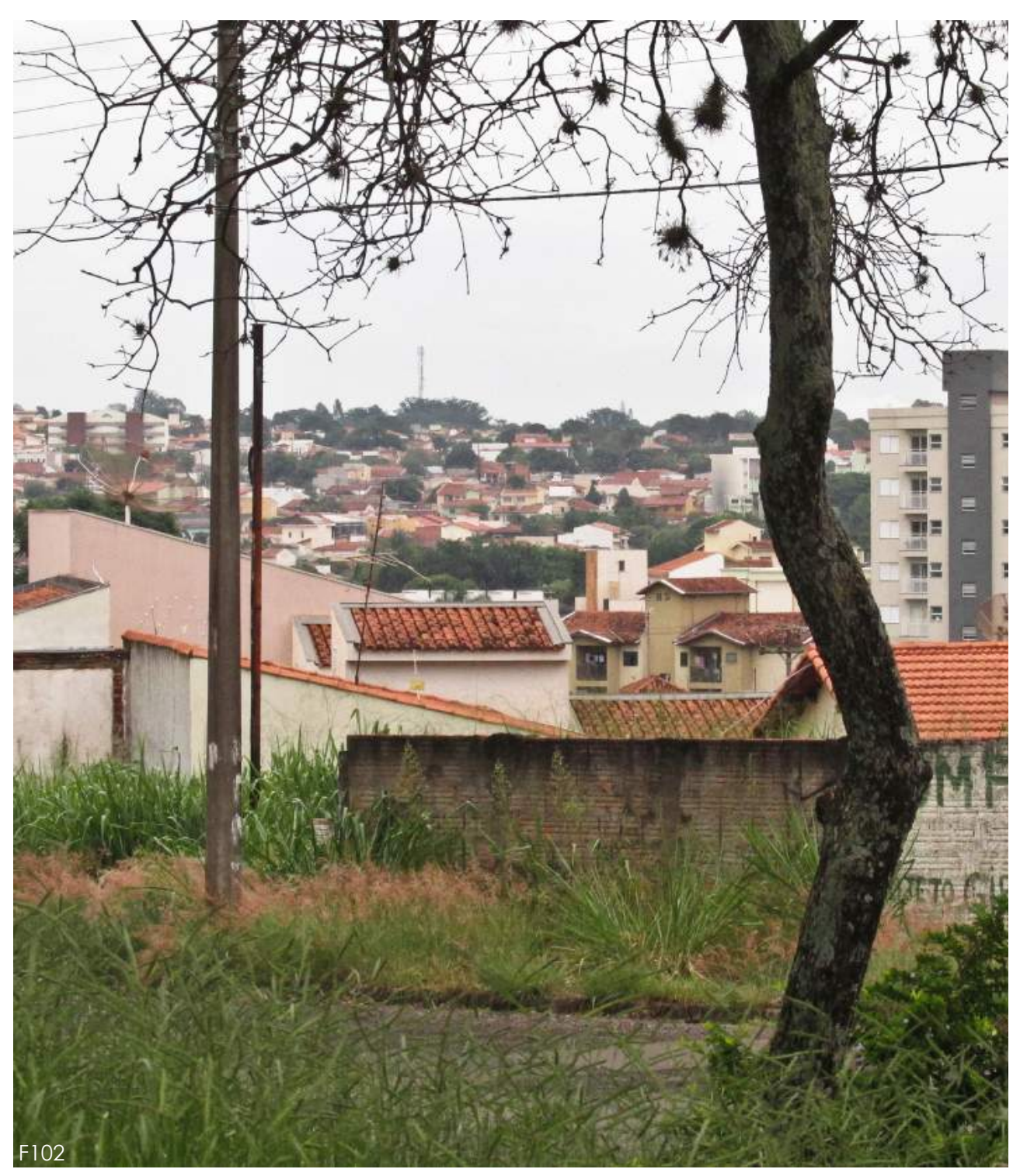

3 Vista a partir da Praça Geraldo Eugênio Toledo Pizza

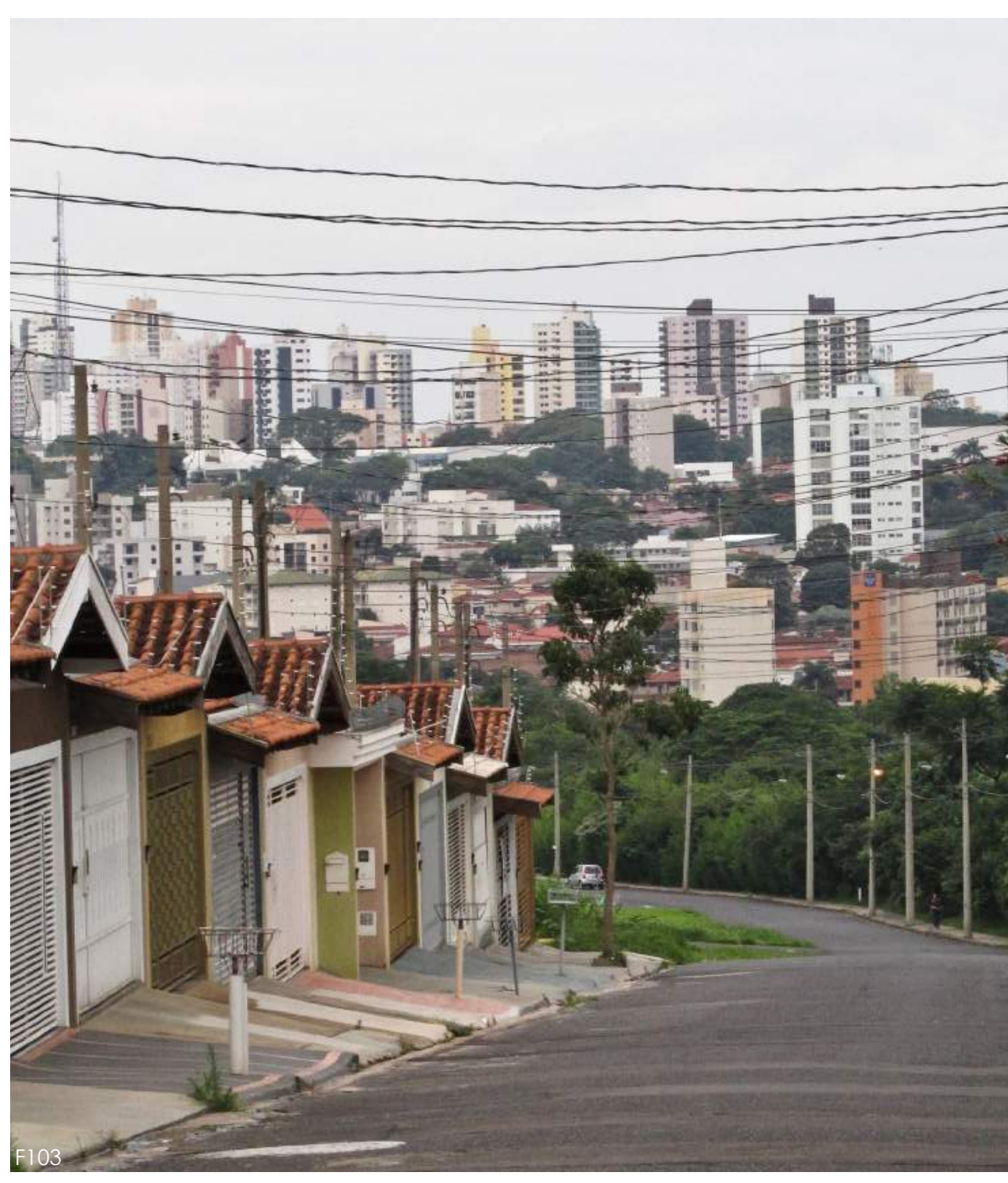

4 Vista a partir da Rua Sebastião Sampaio Osório, próximo ao Bosque Regynaldo Zavaglia 


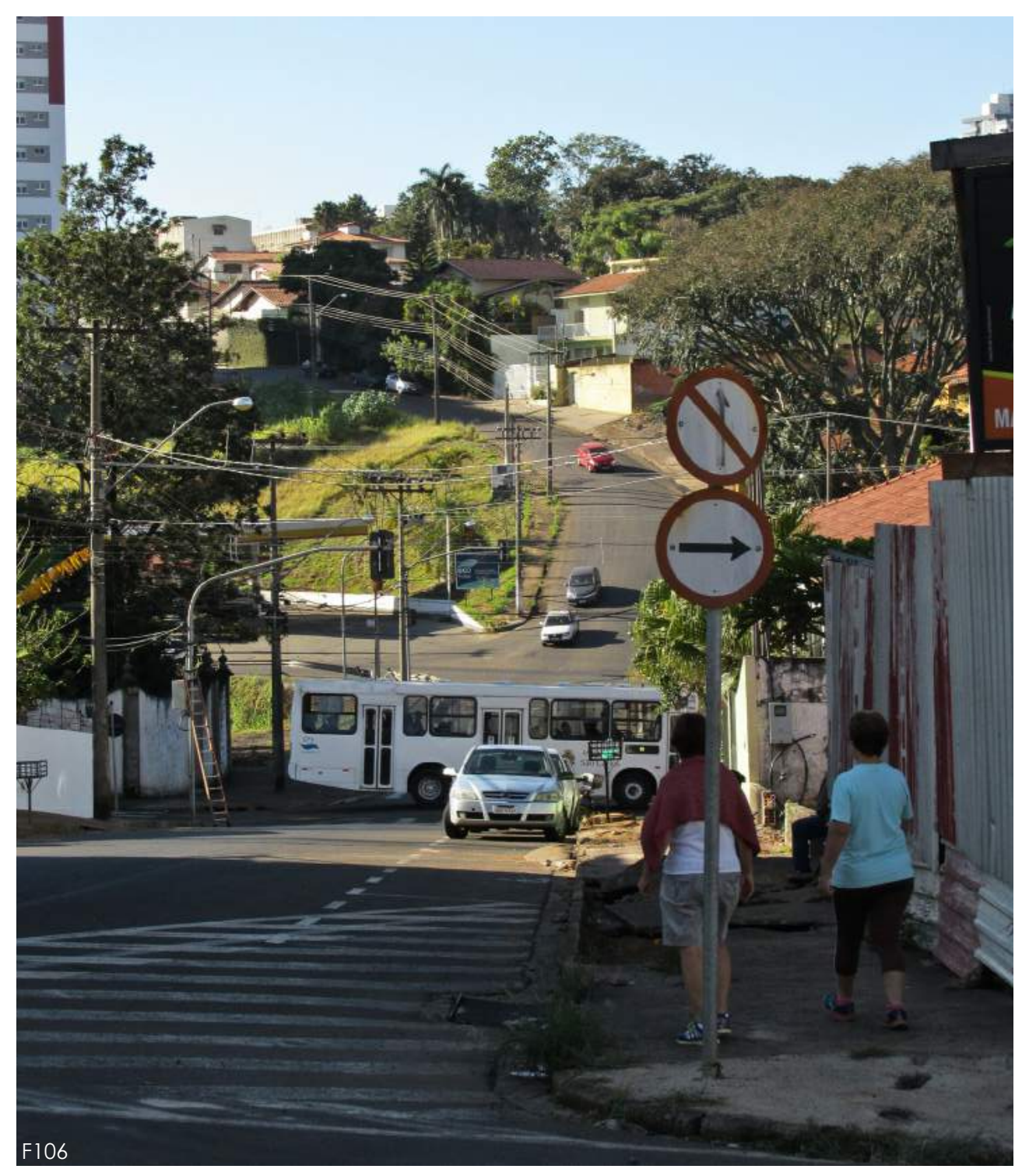

7 Vista a partir da Rua Ângelo Passeri

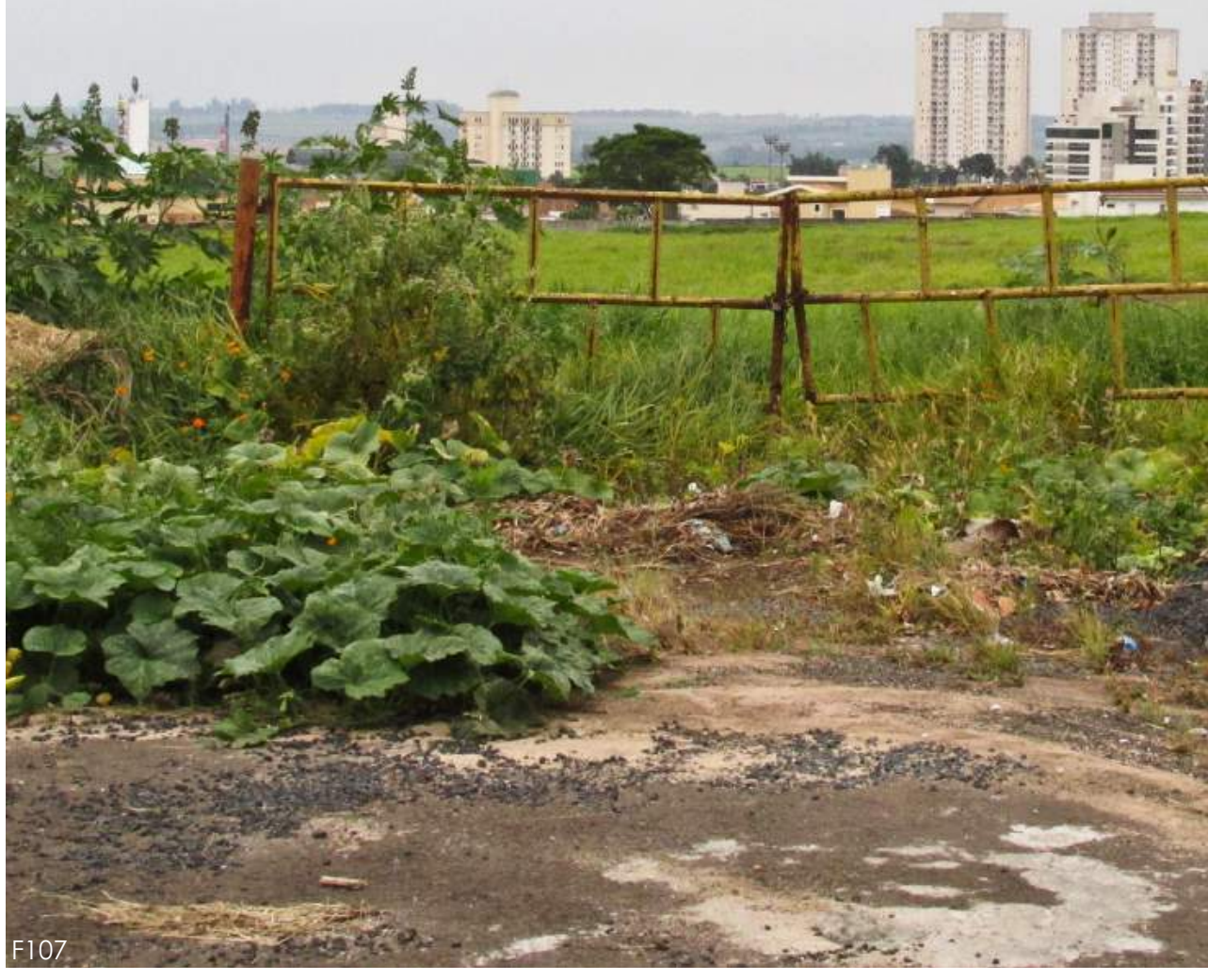

8 Vista a partir do fim da Rua Noêmia Sampaio de Souza, em frente a uma gleba em processo de loteamento 


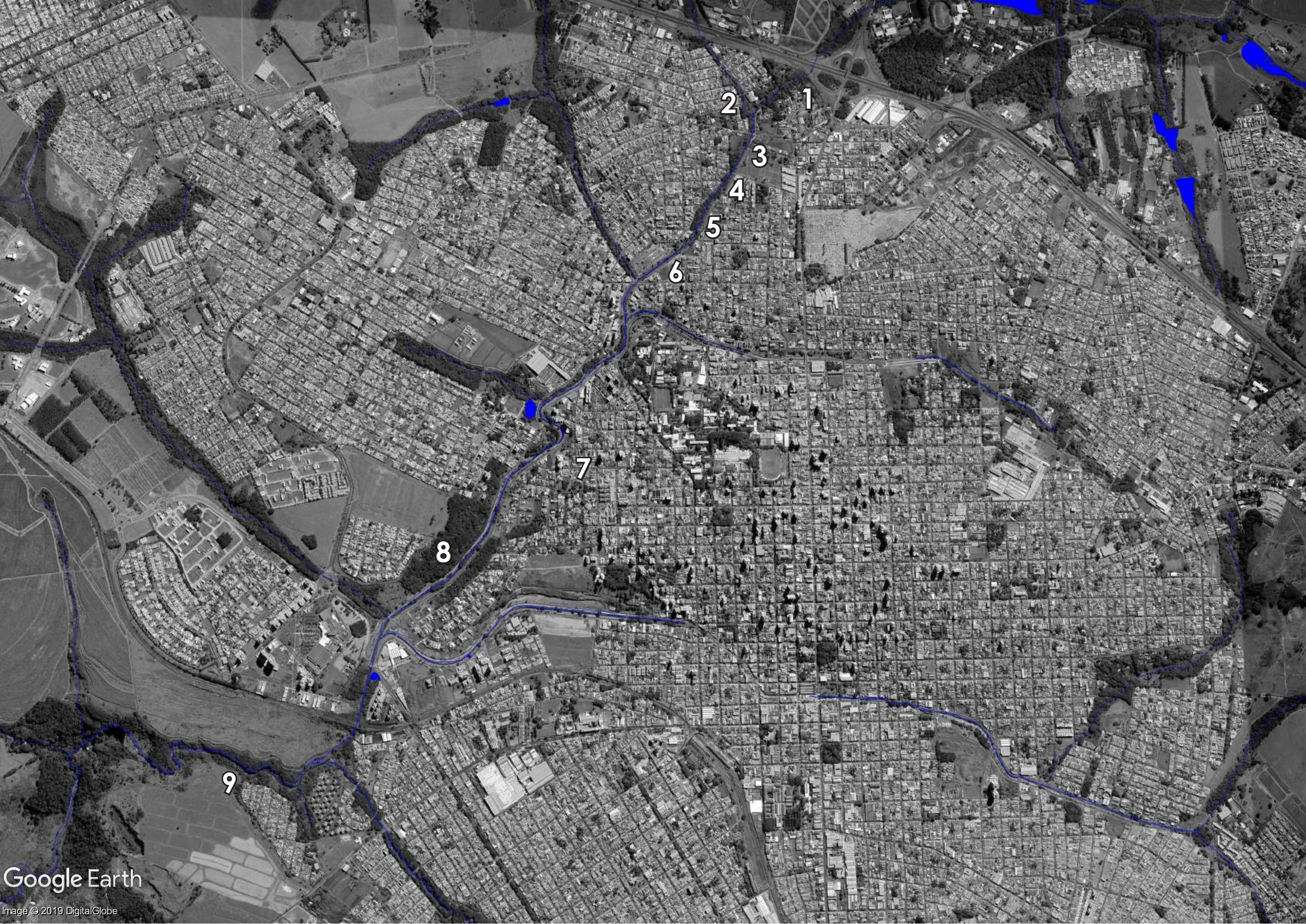




\section{RECORTES}

\section{Potenciais paisagens}

Após desvelar a diversidade que compõe as paisagens do córrego Monjolinho, encontra-se em certos lugares a conjunção de algumas qualidades. Partindo de uma visão pessoal, novas leituras podem suscitar outras interpretações, caracterizando um processo que não encontra um fechamento, mas está em contínua produção, criando reconexões e ressignificações (DELEUZE, GUATTARI, 1995; DIDI-HUBERMAN, 2013).

O relato dá sentido àquilo que se vê e se experimenta (ALIATA; SILVESTRI, 2008) e auxilia na explicitação dessas paisagens e no prolongamento de experiências efêmeras e intangíveis que podem ser desencadeadas durante o processo de frequentação do território.

O processo de projeto da paisagem se desenvolve em conjunto com essas leituras que se mantém abertas. Através do relato e do processo descritivo é possível agenciar as diversas qualidades de uma paisagem (a materialidade, o significado, a sensação) que podem ser traduzidas em diretrizes de projeto.

Propõe-se os recortes subsequentes, selecionados em meio às paisagens do córrego Monjolinho, que reúnem lugares representativos das experiências de paisagem vivenciadas durante o processo de conhecimento do território estudado. 


\section{Recorte 1: uma ponte sobre o córrego}

A Rua Bernardino Fernandes Nunes faz parte de um bairro que margeia a Rodovia Washington Luiz e que apresenta características pouco condizentes com a realidade frenética da rodovia. Trata-se de região residencial, pontuada por pequenos comércios e muitos terrenos desocupados.

Em um trecho onde essa rua faz a travessia do córrego Monjolinho, existem duas pontes de madeira que ocupam o lugar das calçadas, uma de cada lado da rua. É um detalhe que evidencia despretenciosamente a presença do córrego: aqui o pedestre não caminha pela calçada de uma rua asfaltada qualquer; ele atravessa, por uma ponte de madeira, um curso d’água.

A curiosidade pelo lugar instiga a desviar o percurso para a direita e adentrar um trecho arborizado que oculta o Córrego Monjolinho. Descobre-se um pequeno ambiente naturalizado que, não fosse o rastro de entulho que demarca a entrada para essa paisagem, pensar-se-ia que fosse um lugar em que a ação humana ainda não se fez presente.

O que existe mais distante das margens é ocultado pelas árvores, o que cria a ilusão de um bosque que se estende indefinidamente, apagando a presença da cidade que existe em volta.

Assim como começa, o trecho termina abruptamente, com o ruído incessante da Rodovia Washington Luiz, parcialmente revelada pelas frestas da vegetação. 


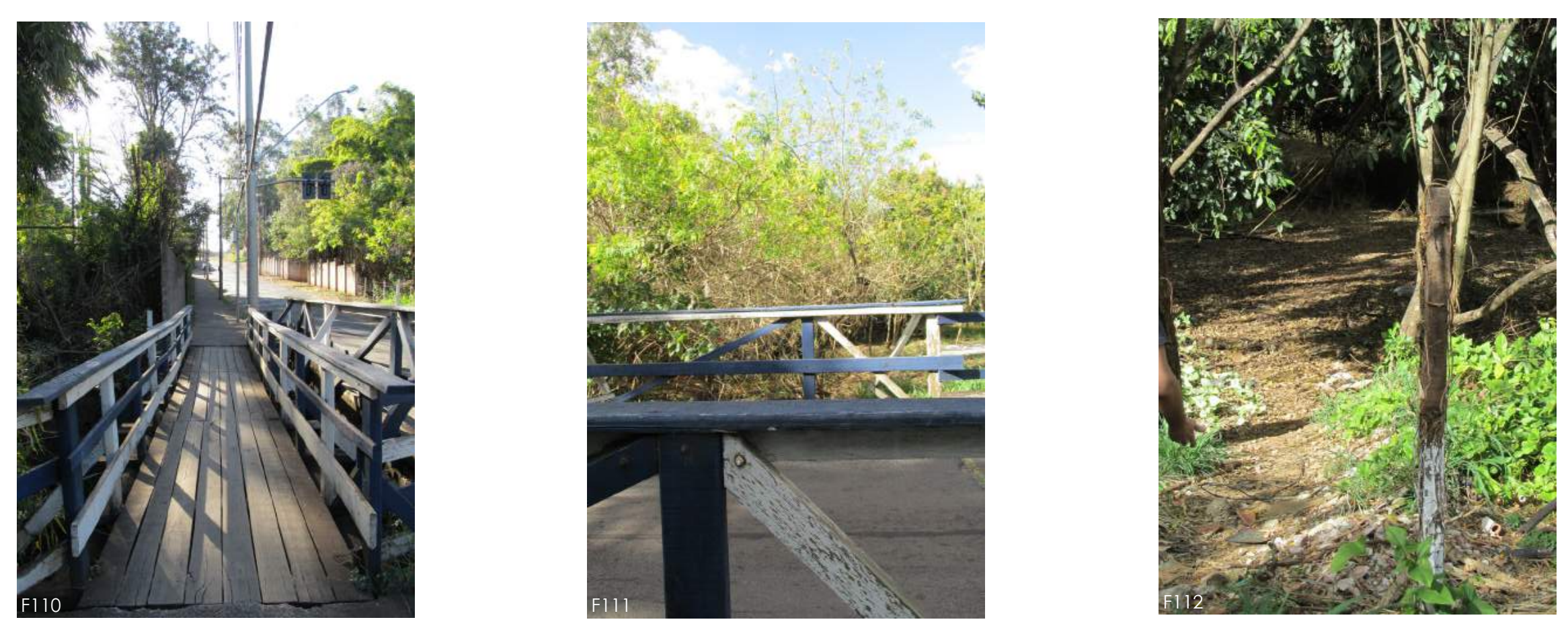


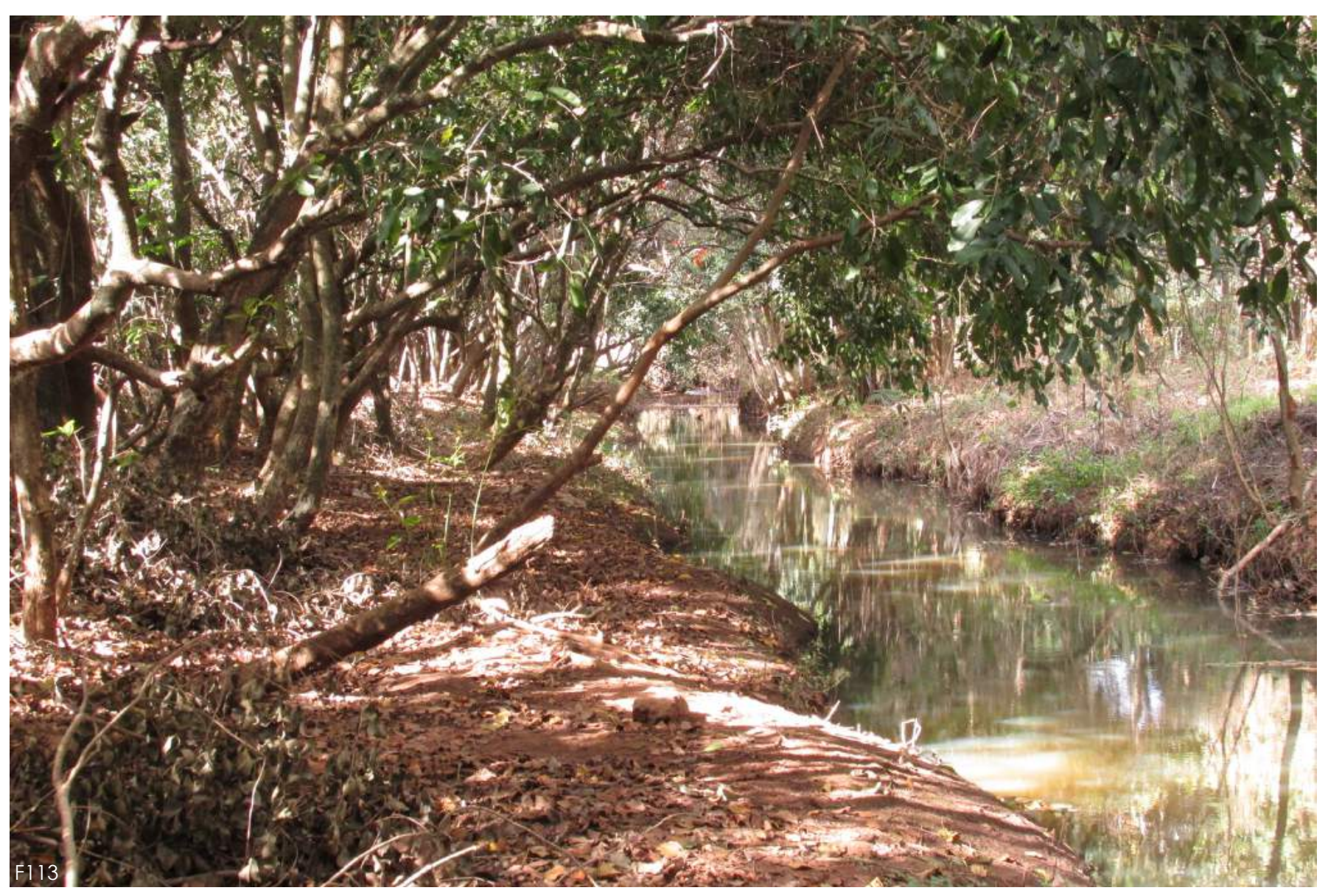




\section{Recorte 2: um quintal}

A rua Ângelo Lucato é uma rua local como outra qualquer, com uma série de residências sem recuo lateral ou frontal, algumas chegando a dois pavimentos. Em determinados momentos, alguns moradores sentam na calçada ou permanecem nos portões de casa, conversando e observando a rua, sem muito movimento. Caminhar por essa rua como estrangeiro suscita a sensação de estar invadindo uma sala de estar.

Em um trecho, as casas estão dispostas em frente a uma área arborizada que esconde o que existe em seu interior. É uma pista que indica a presença de um curso d'água, o que é confirmado pela consulta de uma imagem de satélite, que revela um córrego que desagua no Monjolinho.

Um banco improvisado foi instalado na área arborizada, posicionado de frente para a rua (ou para o interior dessa área verde). Atrás do banco, descobre-se um espaço livre com o chão forrado de folhas secas e plumas de paineira e uma pequena casa de madeira para passarinhos. O sol incide suavemente no local, filtrado pelas folhagens das árvores, criando um microclima fresco. Ao fundo, observa-se a passagem do pequeno córrego, cujo acesso é impedido pela vegetação e pela declividade do terreno.

Esse espaço modesto parece ser uma extensão das casas da rua, um quintal onde os moradores podem passar o tempo ao ar livre sem que sua privacidade seja perturbada. 

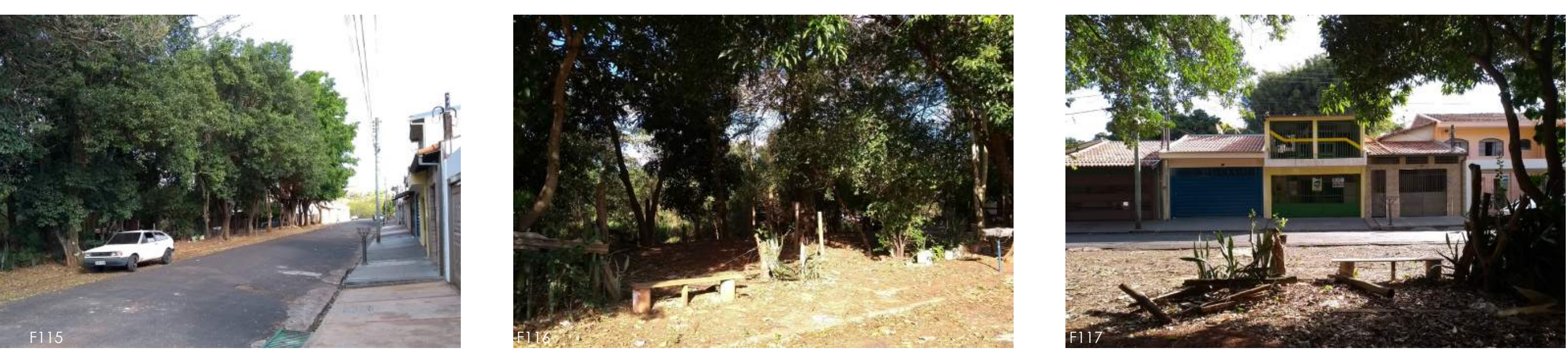

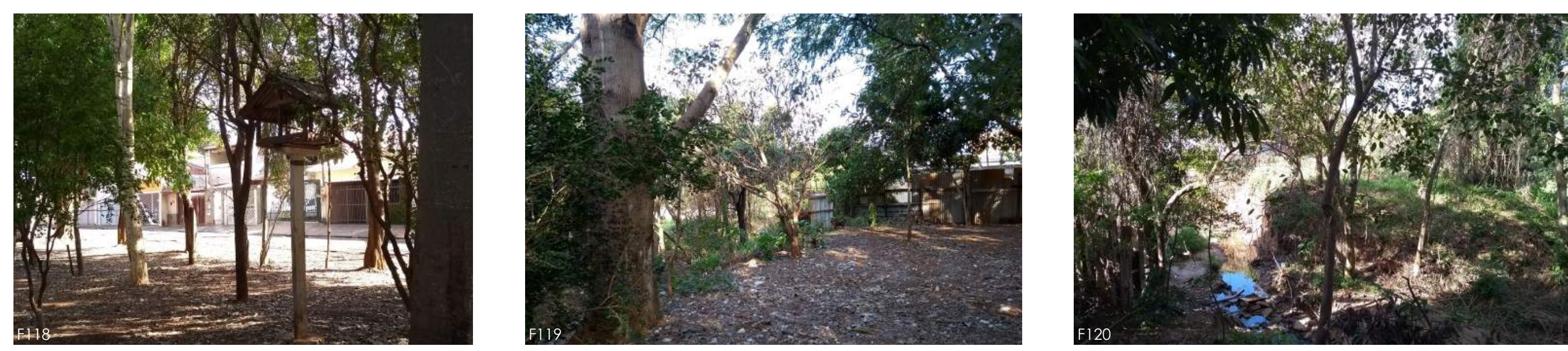


\section{Recorte 3: contraste de escalas}

Um grande espaço livre privado na margem esquerda do córrego Monjolinho reúne diversas qualidades de uma paisagem indeterminada.

Dois pilares de alvenaria na Alameda das Violetas indicam a entrada para um lugar que não existe mais. Ao fundo, as costas de galpões que se voltam para a rua Bernardino Fernandes Nunes são paredes com uma coloração escurecida que concede à paisagem um aspecto de abandono e ruína.

Esse grande espaço livre permite a visualização de todo o entorno, das residências que se alinham nas suas laterais e o relevo que descende em direção ao córrego.

A vegetação que se distribui por todo o terreno se transforma constantemente. Se em um momento toda a área é coberta pelo capim que floresce e tinge a paisagem com tons de verde e branco, pouco tempo depois o mesmo espaço pode se encontrar carbonizado e coberto por texturas marrons e negras.

Paralelamente ao córrego, o solo é gravado por uma trilha que indica a realização passada e futura de um percurso.

Este parece ser o avesso da cidade, uma parte que não precisa ser vista, onde nada acontece, para onde as edificações voltam suas costas (ou laterais). Apenas os usos subversivos a frequentam para cortar caminhos.

No fim da Alameda das Violetas, caminhantes podem atravessar o córrego Monjolinho por uma ponte de madeira (que aos poucos vai perdento alguns de seus componentes). No outro lado da ponte há um pequeno nicho com alguns bancos, configurando um conjunto singelo desproporcional à amplitude da paisagem estabelecida na margem esquerda do córrego. Essa travessia faz conexão com um espaço livre público que ainda não recebeu um uso institucional, apenas bancos improvisados e traves de um campo de futebol provisório.

F121: recorte 3

Fonte: elaborado a partir de imagem do Google Earth e carta de áreas públicas, SMHDU, 2015. 

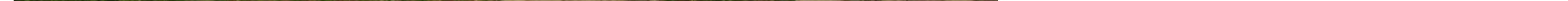


\section{Recorte 4: confinamento}

Partindo do recorte 3 e percorrendo a margem esquerda do córrego Monjolinho, um longo trecho de indeterminação se estende até a próxima travessia, na Alameda dos Heliótropos.

Esse trecho se configura como um corredor limitado, de um lado, pela vegetação que cobre as margens do córrego, de outro, por muros que resguardam as residências e outras edificações. Ao longo desse percurso, podem estar espalhados entulhos, resíduos de paisagens determinadas. A vegetação que se desenvolve sem nenhum tipo de controle se mistura aos resíduos criando rastros de cores e texturas que confundem matéria natural e fabricada.

De modo intermitente, é possível escutar pessoas conversando ou crianças brincando na margem direita equanto, ao fundo, o ruído constante da água corrente.

Todo o percurso é marcado por uma trilha dupla, que denuncia a passagem frequente de veículos no local.

É como se fosse atravessado um espaço confinado que obscurece a presença do restante da cidade, mas que em alguns breves momentos, revela seu contexto. 


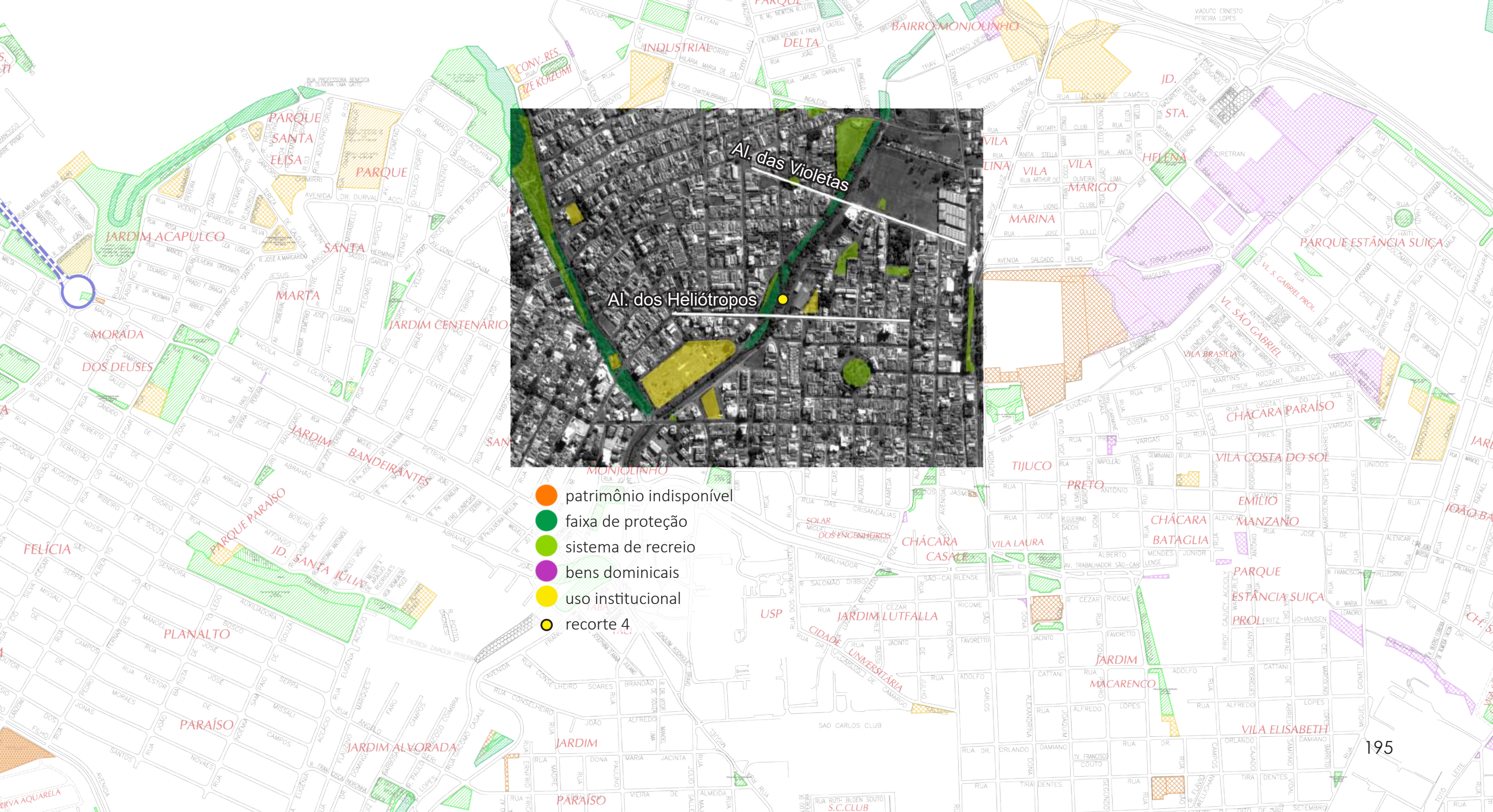




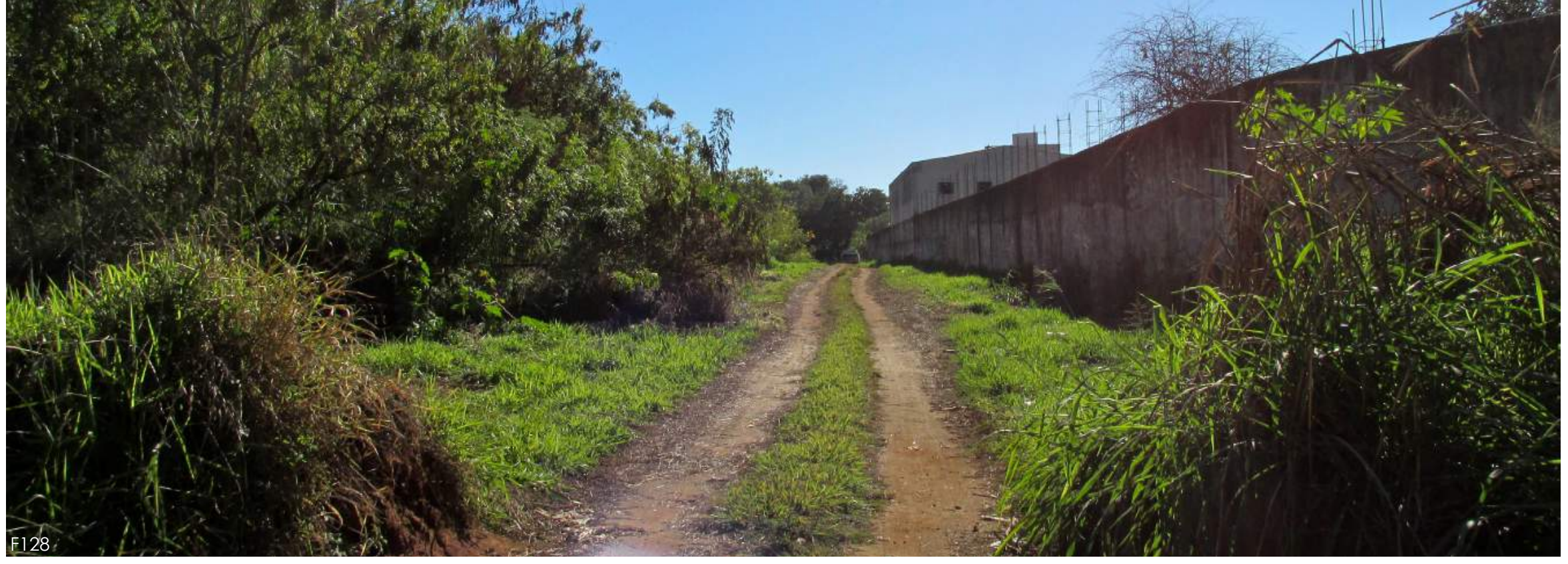

196

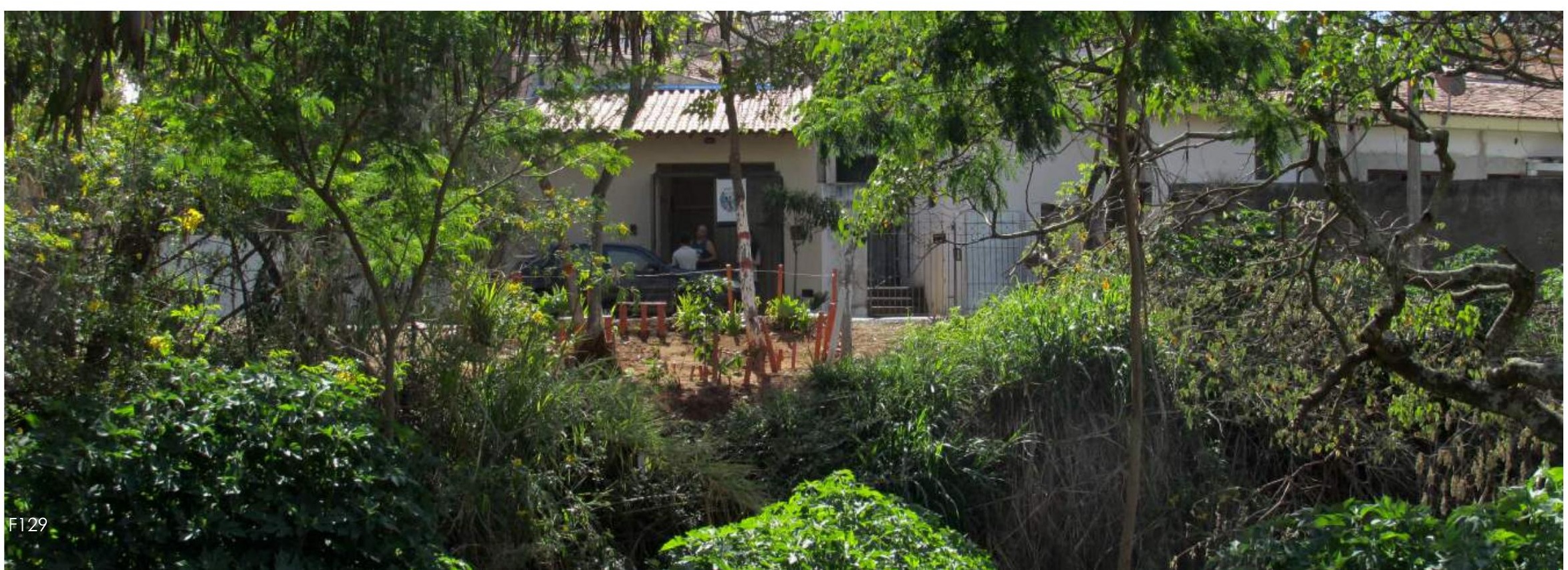



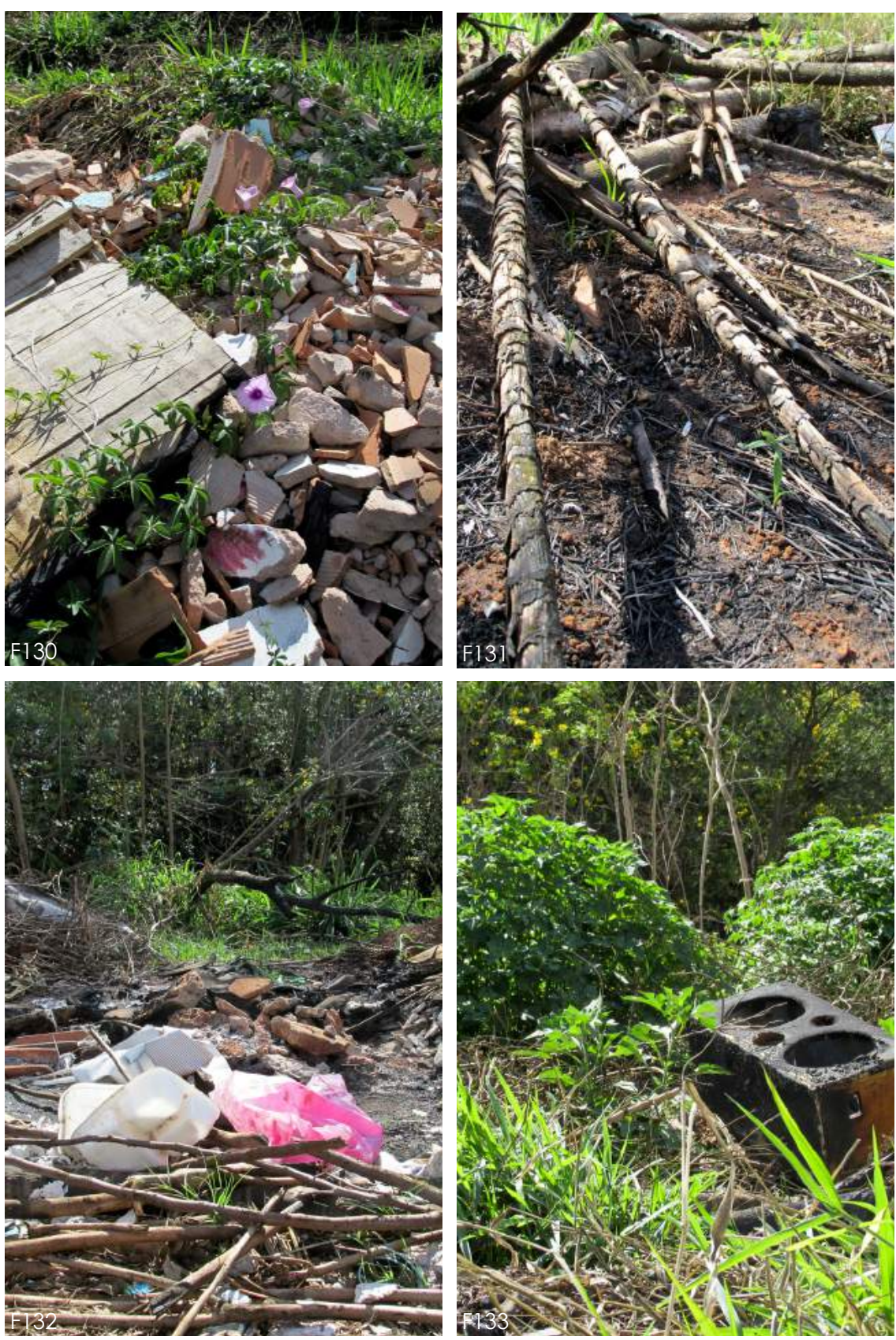


\section{Recorte 5: a Avenida e a Alameda}

A Alameda dos Heliótropos promove uma travessia do córrego Monjolinho de qualidade distinta do recorte 1. Trata-se apenas de uma rua asfaltada com calçadas de concreto que, mesmo assim, permite uma perspectiva pouco usual do córrego, revelando uma paisagem vegetada que destoa do contexto impermeabilizado.

Neste ponto, nota-se, à esquerda, uma rua sem pavimentação sombreada pelas árvores que resguardam as margens do córrego. Parece ser uma via local, acessada apenas por pedestres que buscam um percurso mais curto para seu destino ou moradores da própria rua.

Nela, pode-se ouvir o rumorejar das águas do Monjolinho e apreciar um curto percurso sombreado, com muita vegetação e ar fresco. Parece ser uma agradável paisagem que se contrapõe ao asfalto seco e ao sol intenso presentes na Alameda dos Heliótropos, não fosse pelo forte odor de esgoto.

Ironicamente, uma consulta à carta de arruamentos da cidade permite identificar essa via que margeia o córrego como sendo a Avenida Francisco Pereira Lopes, a mesma avenida marginal que confina parte do curso do Monjolinho e o transforma em paisagem determinada. Essa avenida imaginária atravessa também o recorte 4 até alcançar o recorte 3.

Nestes trechos, a avenida ainda é espaço indeterminado, não recebeu asfalto, não apresenta limites tão claros entre via e APP e quase não é perturbada pela presença agressiva de automóveis. 


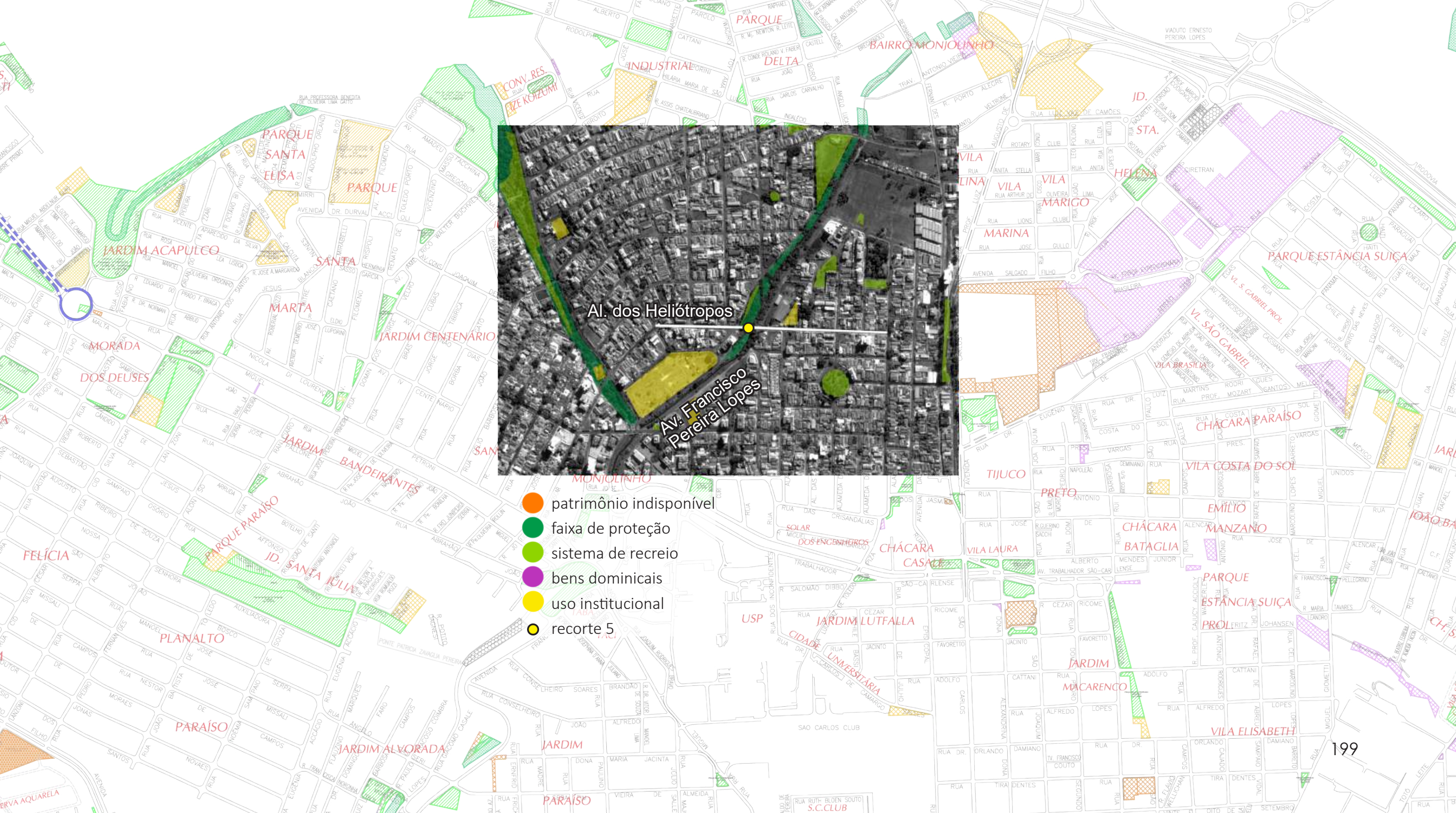




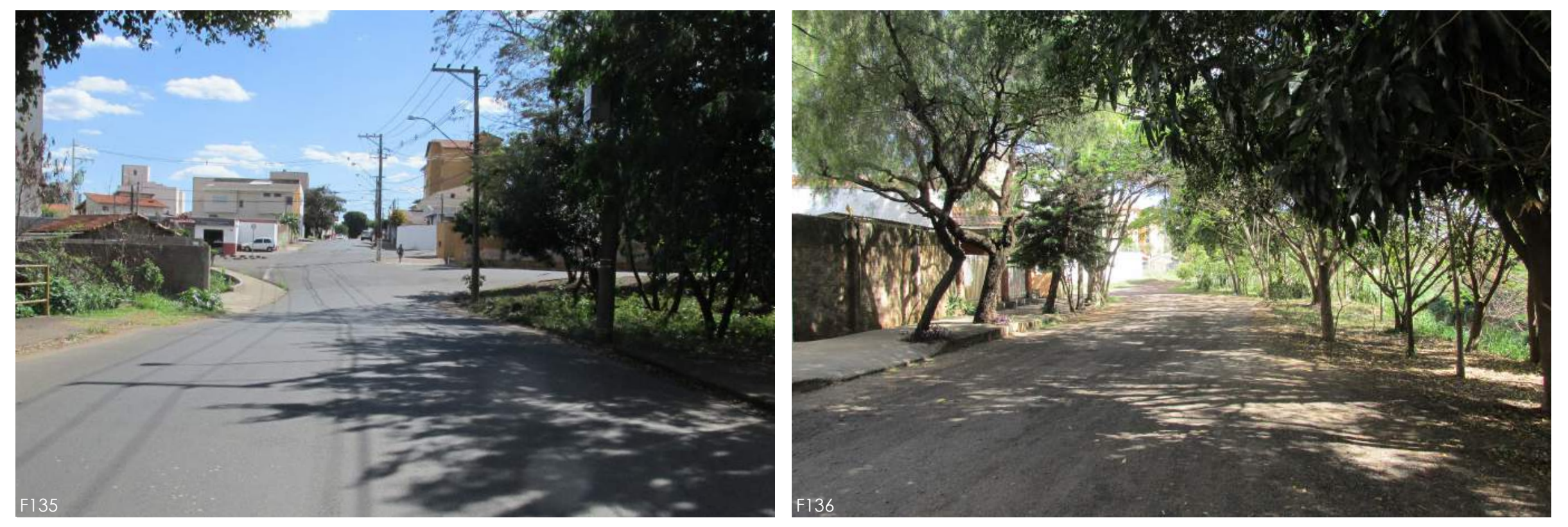



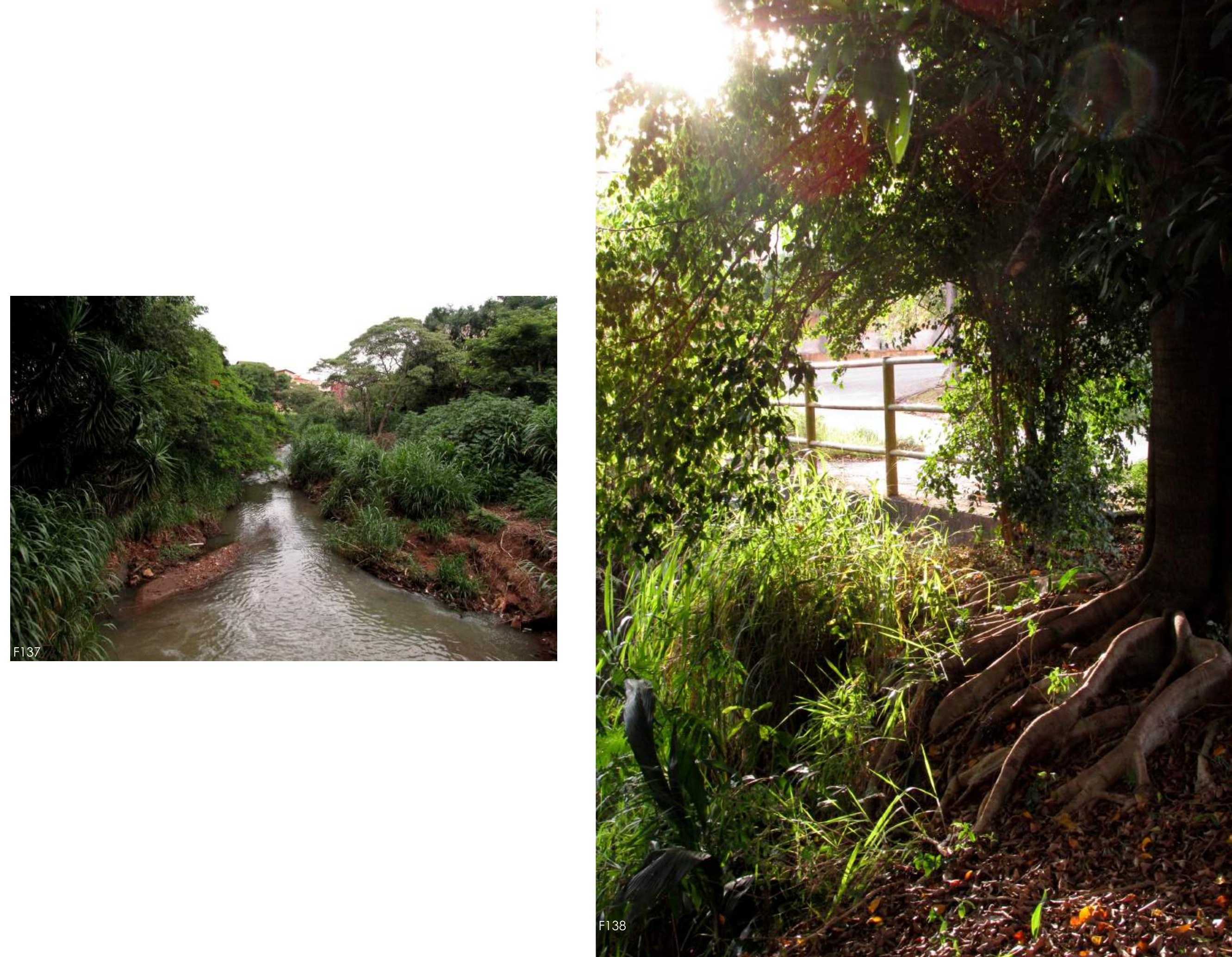


\section{Recorte 6: ponto de inflexão}

Na margem direita do córrego Monjolinho, existe o Parque do Kartódromo, espaço muito utilizado para exercícios físicos e outras formas de lazer. Nos finais de tarde de cada dia, quando parece haver a maior quantidade de pessoas no parque, surgem algumas viaturas para observar o local. Nas sextas feiras brinquedos infláveis e barracas são montadas, e uma música ao vivo anima o ambiente da feira.

Na mesma região, na margem esquerda do córrego Monjolinho, a paisagem é outra. Ao longo de um trecho sem travessias, não há asfalto, a vegetação sem o controle da poda se espalha por toda parte. Entre a folhagem das margens é possível visualizar a movimentação no parque do Kartódromo.

Um terreno público sem nenhum uso instituído recebe uma placa que sinaliza a ocorrência de alagamentos no local. A partir de suas cotas mais altas, revelam-se as duas margens contrastantes. Identifica-se uma potencial conexão física entre uma paisagem determinada e uma paisagem indeterminada. 


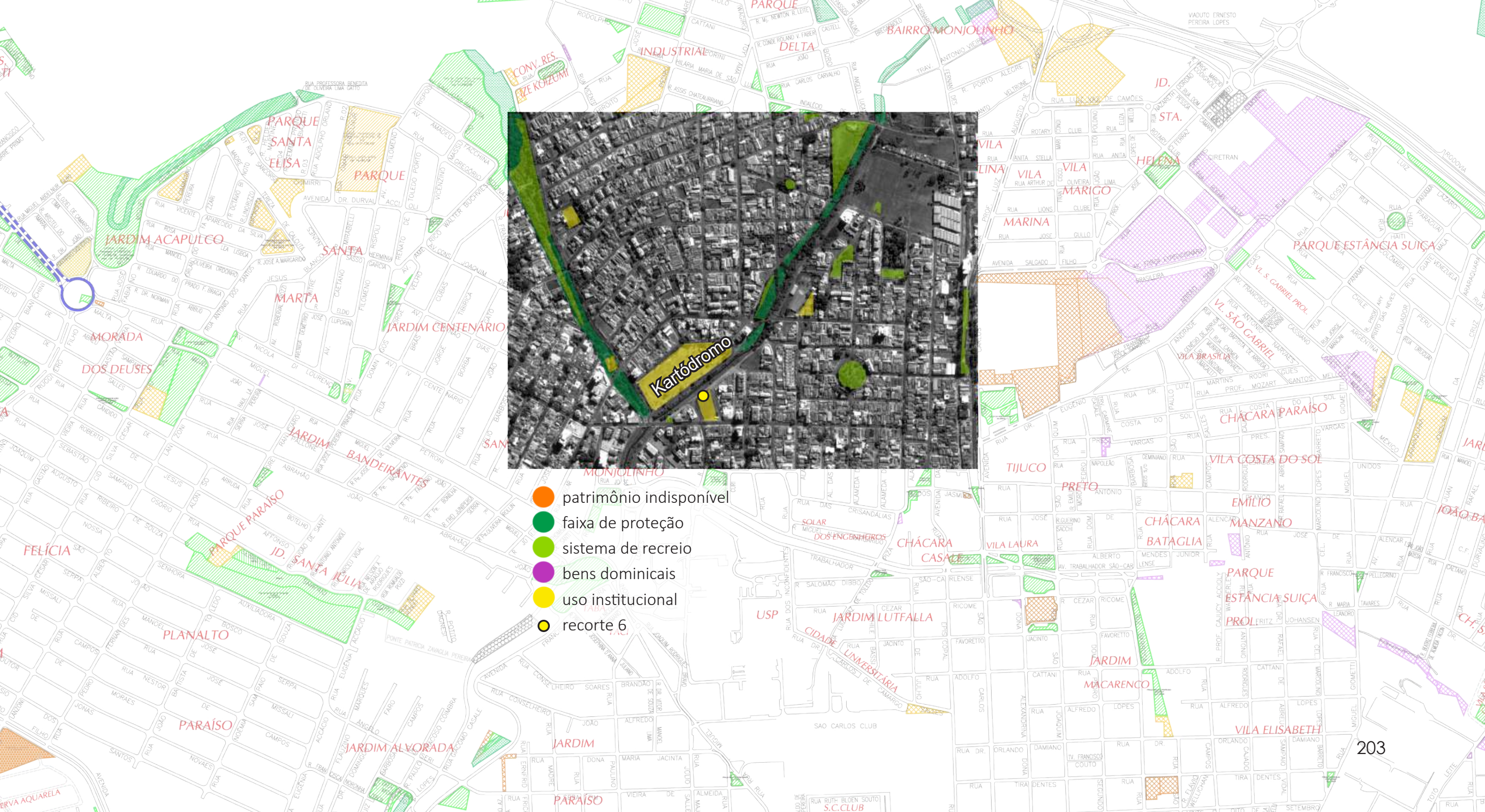



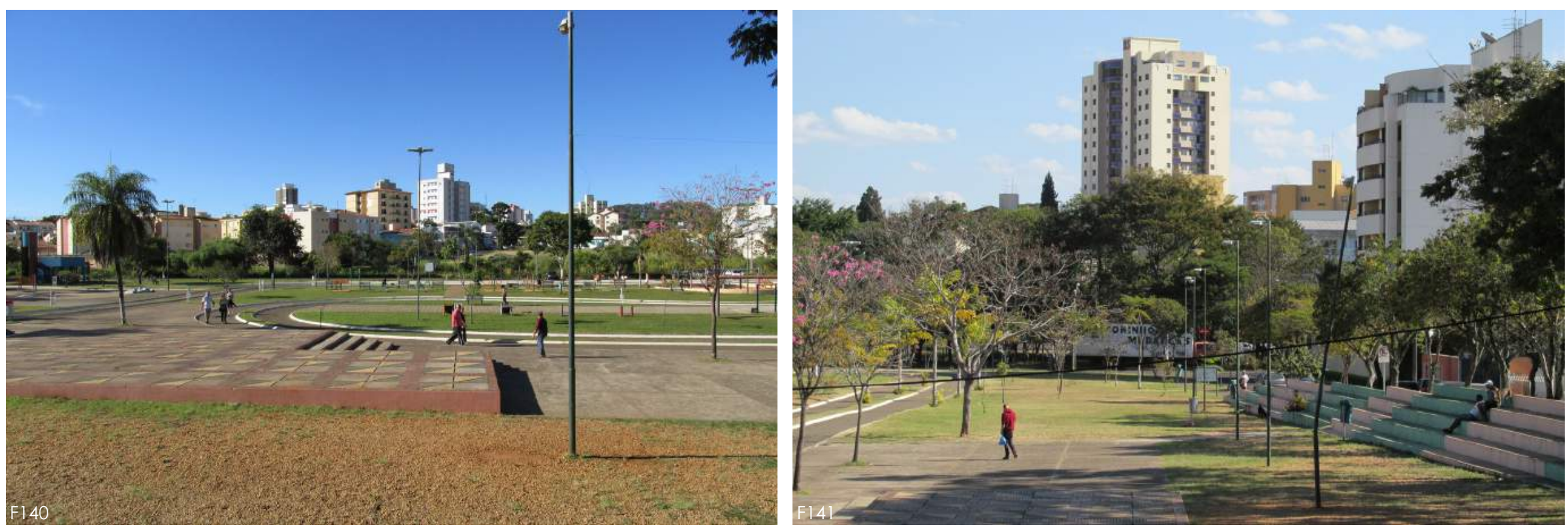

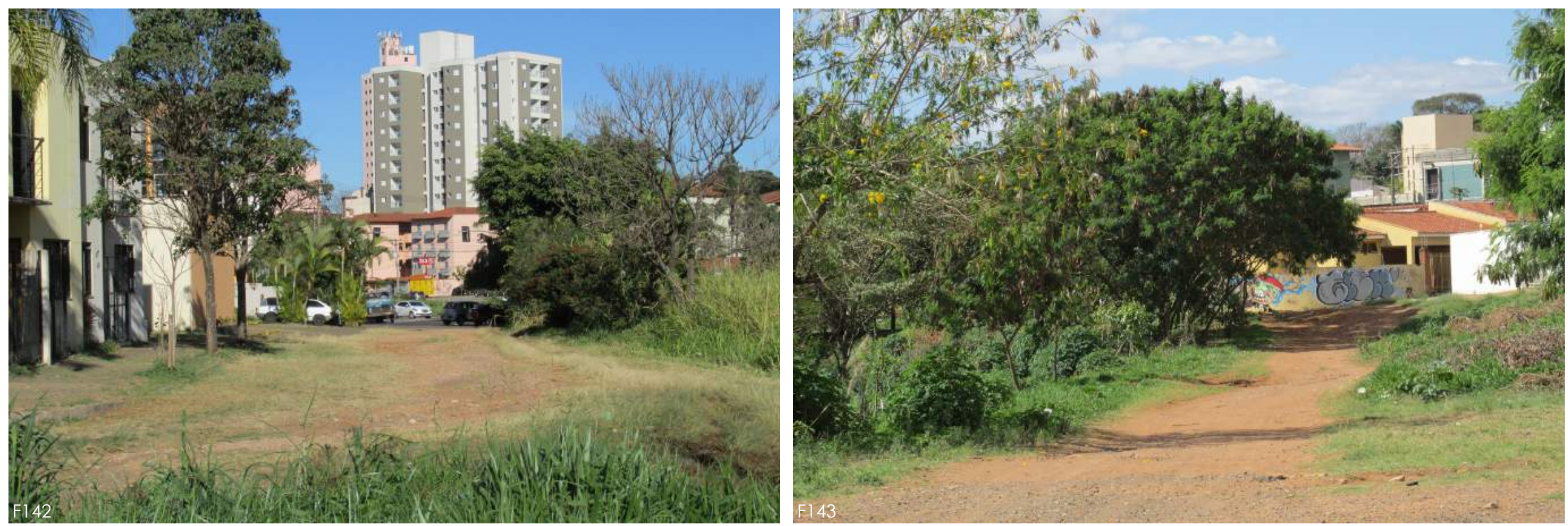


\section{Recorte 7: uma praça caminho}

A praça Prof. Miguel Carlos Stamato é repartida em três patamares que acompanham a declividade do terreno modelado pelo vale do Monjolinho e induz o caminhar a partir da Santa Casa até o córrego.

Esta praça é uma daquelas paisagens determinadas que não cumprem com as funções projetadas. As pessoas que a frequentam parecem usá-la apenas como encurtamento de distâncias, como lugar de passagem. Todo o seu piso em blocos de concreto deixa livre a vegetação que se desenvolve entre suas frestas, sem que seja contida por algum tipo de manutenção.

O primeiro patamar, localizado no ponto mais alto, margeia a rua Maestro João Seppe. Para o caminhante desatento, a praça se passa por terreno baldio atrás de um ponto de ônibus. Apenas com a aproximação é possível notar que, na verdade, trata-se de uma praça que se estende por mais três quadras.

O segundo patamar possui um playground, alguns bancos e fecha uma rua sem saída, criando uma estranha sensação de espaço interrompido. Ao direcionar o olhar para o playground, é possível enxergar o horizonte da cidade, o que remete à presença de um curso d'água que molda o território, possibilitando a visão desse panorama.

O terceiro patamar é configurado por uma forma quase circular com alguns bancos em sua borda. A partir desse último patamar, o relevo se torna ainda mais íngreme, ocultando o que existe adiante e instigando o caminhante a procurar o vale.

Observando a carta de espaços públicos de São Carlos, é possível reconhecer que esta praça, não apenas induz o caminhar até o córrego, como também apresenta o potencial de compor uma sequência de espaços livres públicos que se distribuem em ambas as margens do córrego Monjolinho e que podem ser conectados por vias e córrego.

F144: recorte 7

Fonte: elaborado a partir de imagem do Google Earth e carta de áreas públicas, SMHDU, 2015. 


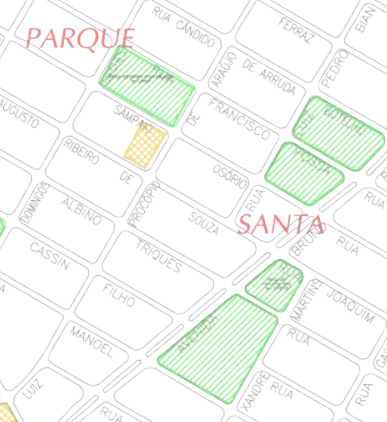

FELICIA

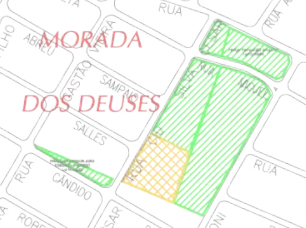

IARDHOS
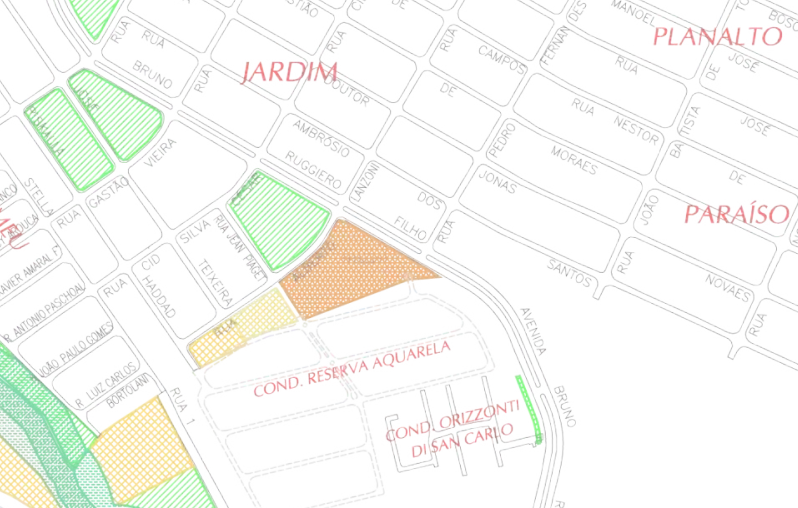

PARAISO
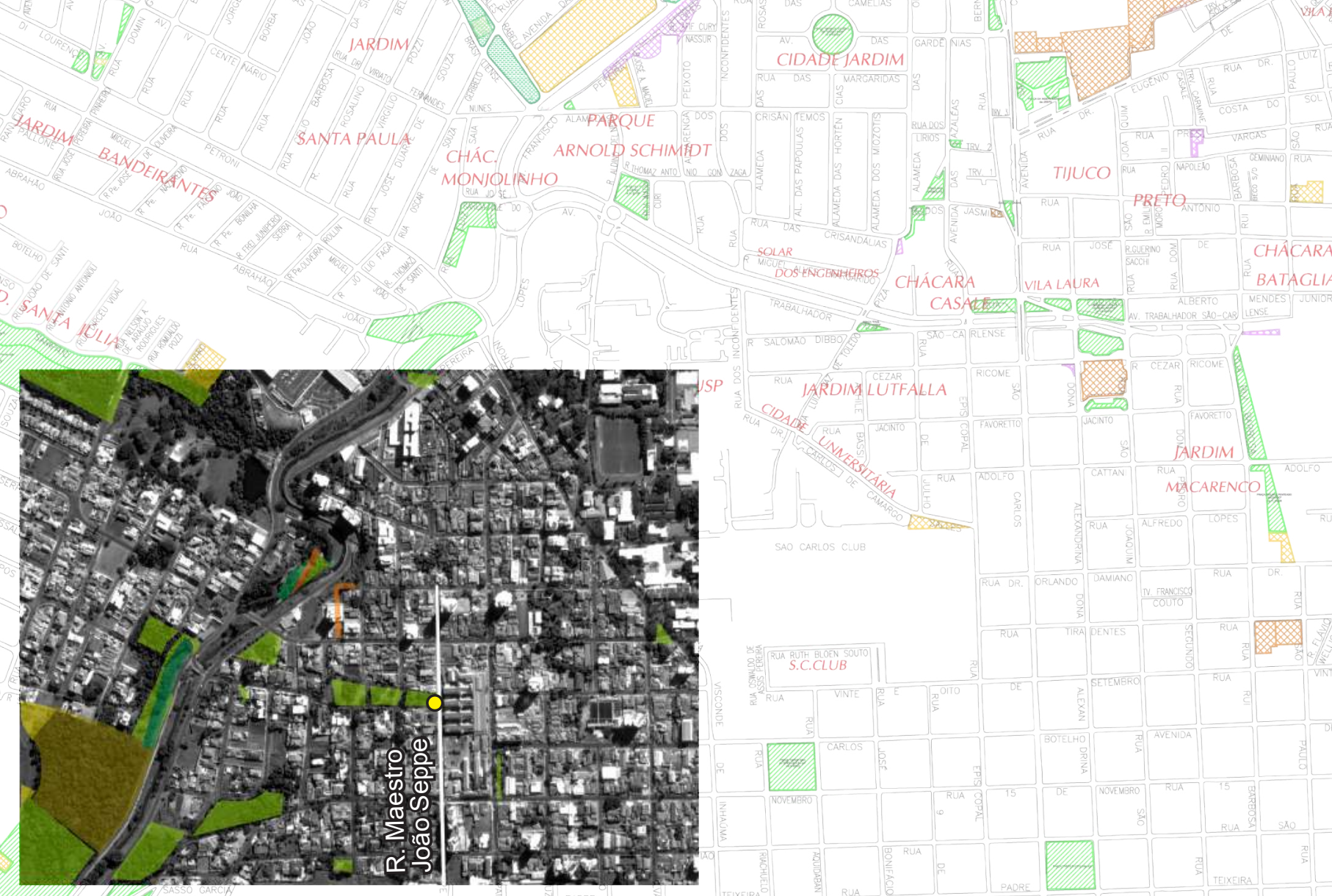

patrimônio indisponível

faixa de proteção

sistema de recreio

bens dominicais

PARQUE FATERE I

uso institucional

o recorte 7
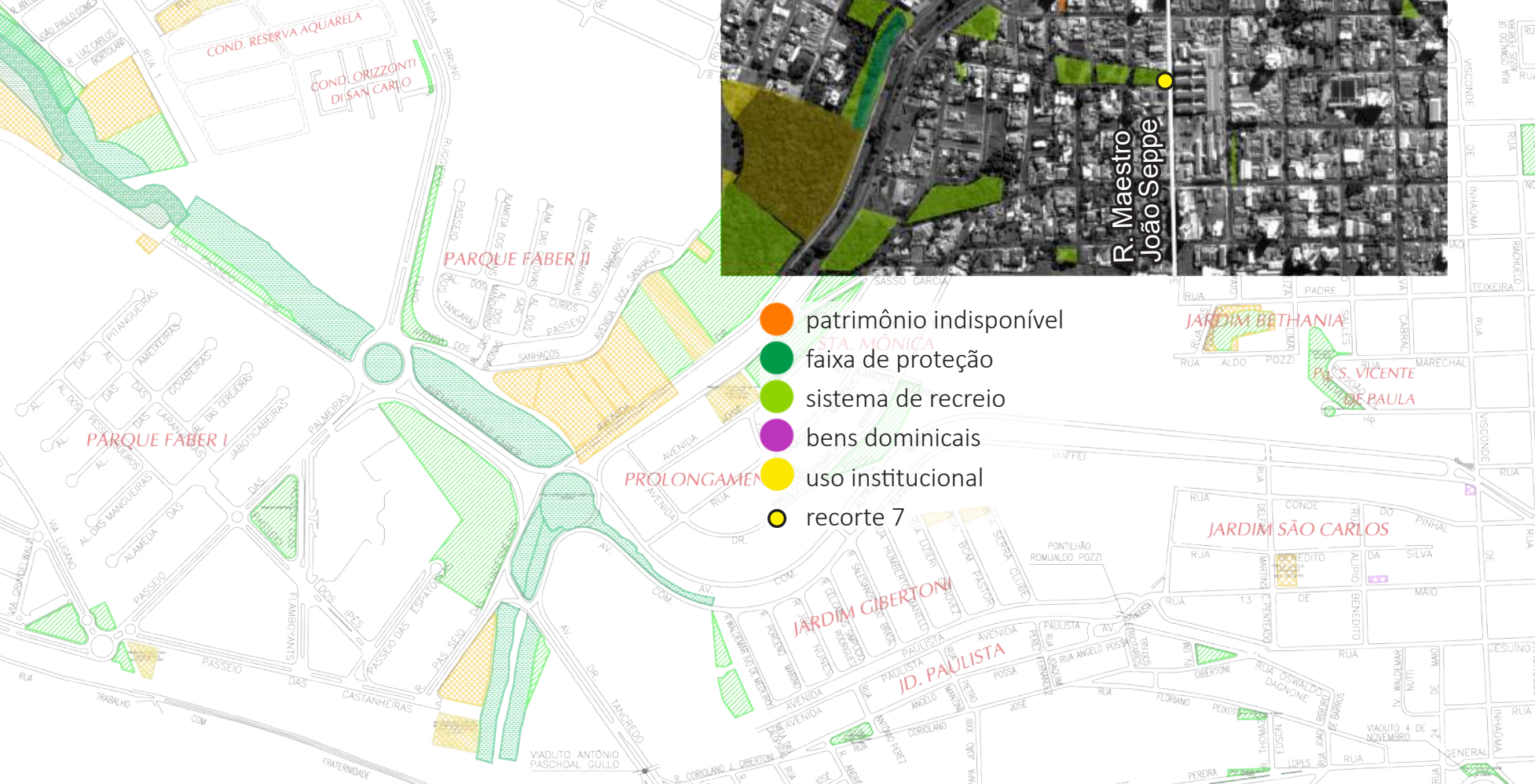

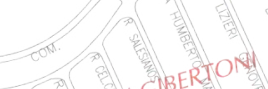




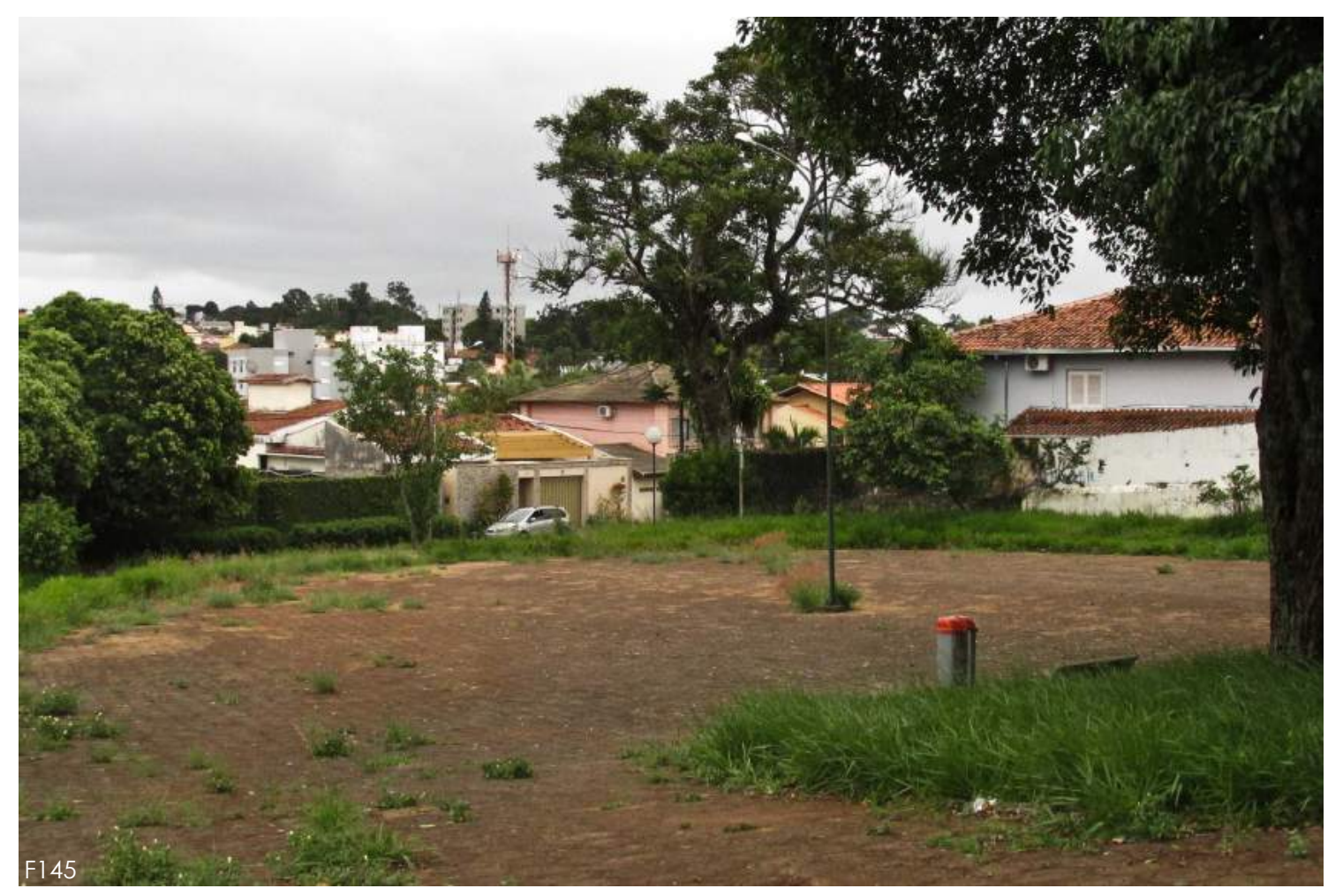




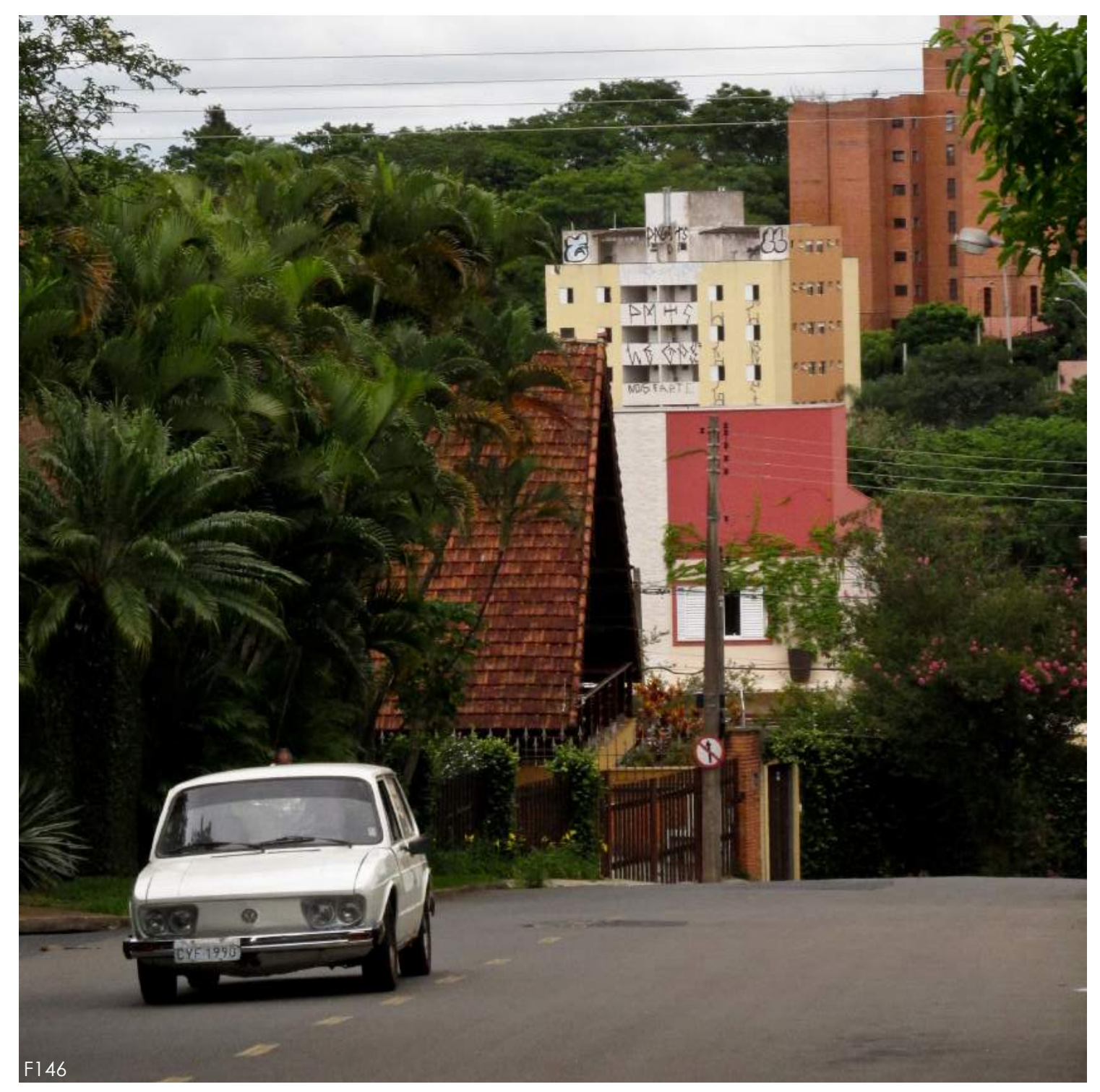




\section{Recorte 8: duas vertentes}

Duas áreas densamente arborizadas foram decretadas como Parques Urbanos de São Carlos e formam vertentes de inclinação acentudada, segmentadas pela Av. Dr. Francisco Pereira Lopes e limitadas por bairros residenciais de alto padrão.

Na margem esquerda do Monjolinho, o bosque é margeado pelas residências do Jardim Santa Mônica e as folhagens de distintos tamanhos e cores formam uma barreira entre o bairro e a movimentação da avenida Dr. Francisco Pereira Lopes logo abaixo. A barreira se consolida pela alta declividade do terreno, que impede o acesso ao bosque, frustrando a curiosidade do caminhante, que pode visualizar brevemente trechos de seu interior entre a vegetação lindeira à Av. José Gonçalves Carneiro.

Na margem direita, o bosque é limitado pela Avenida dos Sanhaços, via externa do condomínio fechado Parque Faber II, e se encontra cercado com arame, com o acesso ao seu interior restrito. Quando autorizada, a entrada nesse bosque permite o contato com aquilo que era imaginado. Seu interior revela um ambiente naturalizado, o chão coberto de folhas e galhos, árvores de distintos portes e troncos caídos e revestidos por uma camada verde de musgo. Mesclada à vegetação, uma ruína, uma pequena construção abandonada. 


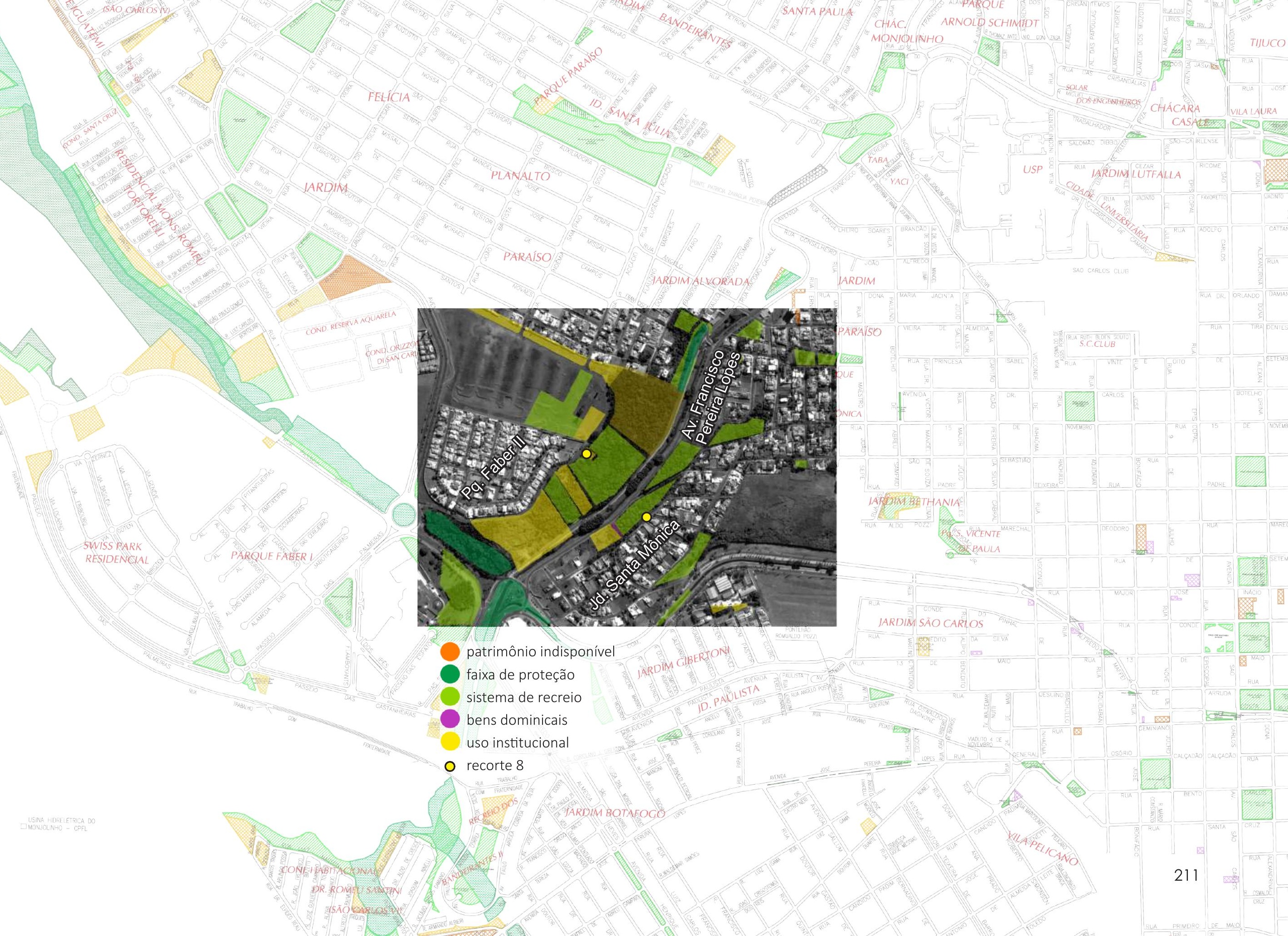



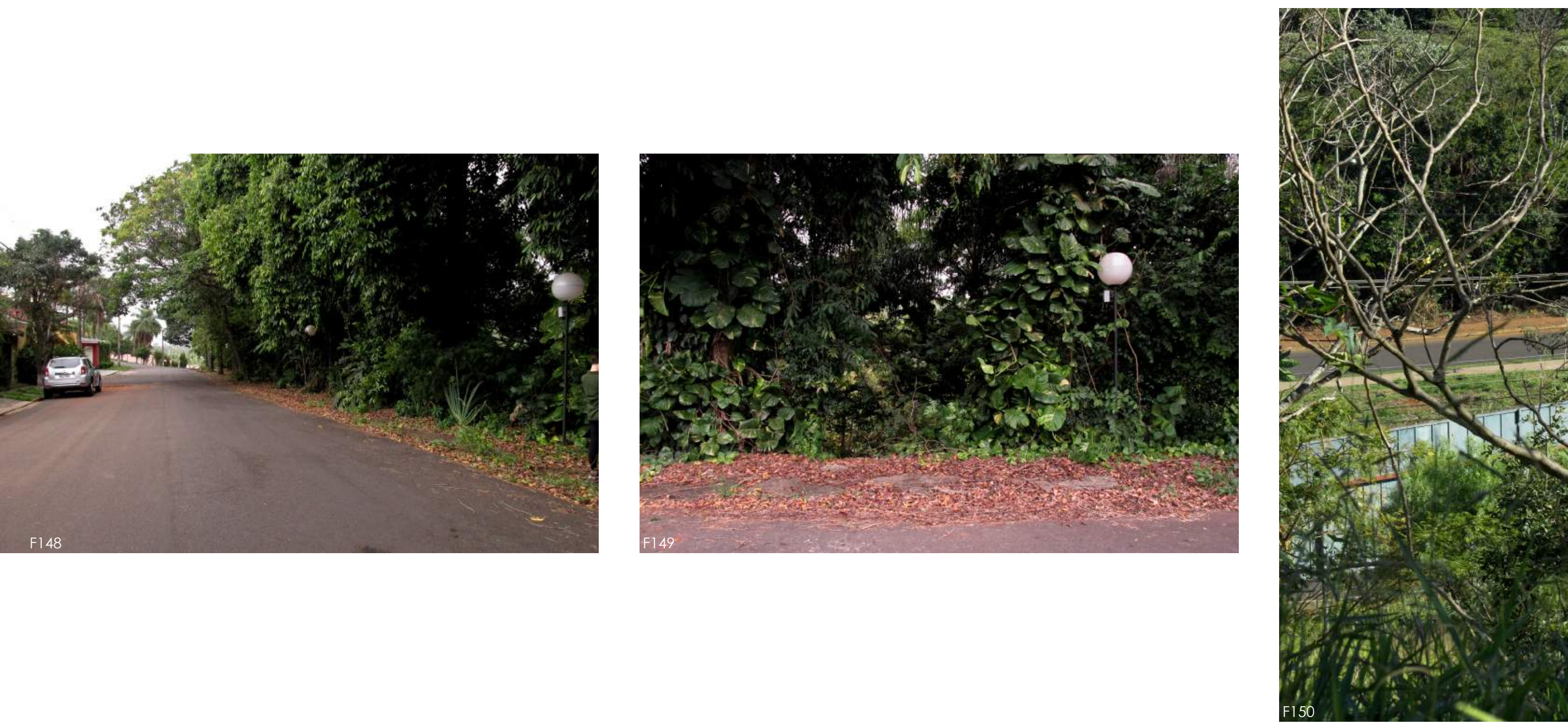

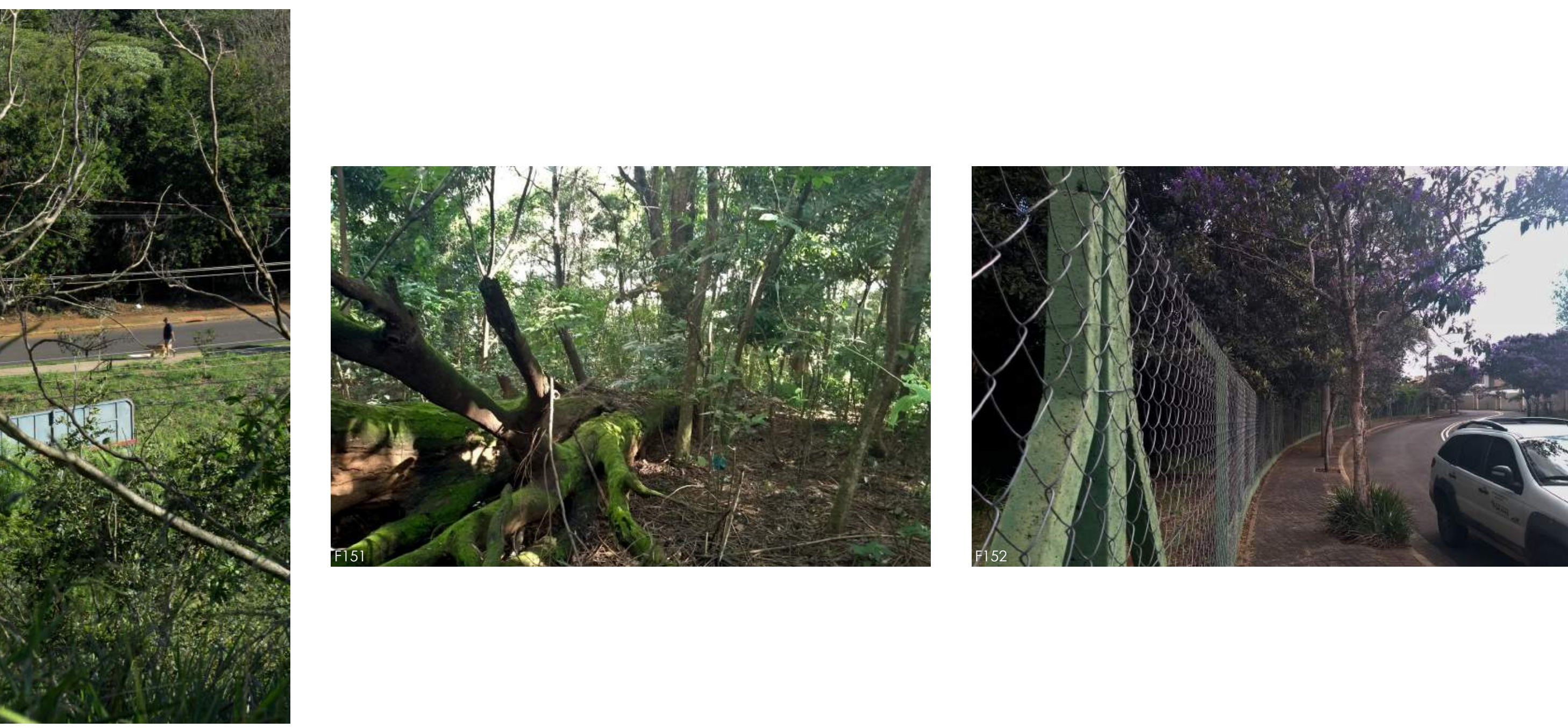


\section{Recorte 9: memória}

Nos limites do perímetro urbano, a cidade vai deixando de acompanhar as margens do córrego Monjolinho.

As bordas do Conjunto Habitacional Dr. Romeu Santini (ou São Carlos VI) são pontuadas por elementos discretos que sugerem o pertencimento dos moradores com relação àquele lugar: um caminho de pedras, um pequeno vaso, cercas. O caminhar por essa borda é arrematado pela visualização de uma barragem construída no Monjolinho, componente da usina hidrelétrica Monjolinho II, que se localiza a cerca de 1500 metros a jusante e resgata uma memória de São Carlos dos primórdios do século XX. Neste local, pode-se observar e escutar o córrego em forma de cascata ao longe.

A segunda porção do Conjunto Habitacional é conectada, para os pedestres, por uma pequena ponte sobre um córrego anônimo. O Monjolinho é revelado esporadicamente entre a vegetação, até a Rua Luiz Masson dobrar e se tornar Rua Geraldo dos Santos Triques. A partir daí, observa-se uma trilha de terra marcada no chão gramado que futuramente será ocupado por um novo loteamento e, como pano de fundo, um rastro vegetado que sinaliza a passagem do córrego Monjolinho em direção à usina Monjolinho II a oeste.

Futuro e passado convivem sutilmente nessa paisagem das bordas provisórias da cidade. O que antes era distante, fora do contexto urbano de 1907, vai se tornando cada vez mais próximo das formas contemporâneas de cidade. 


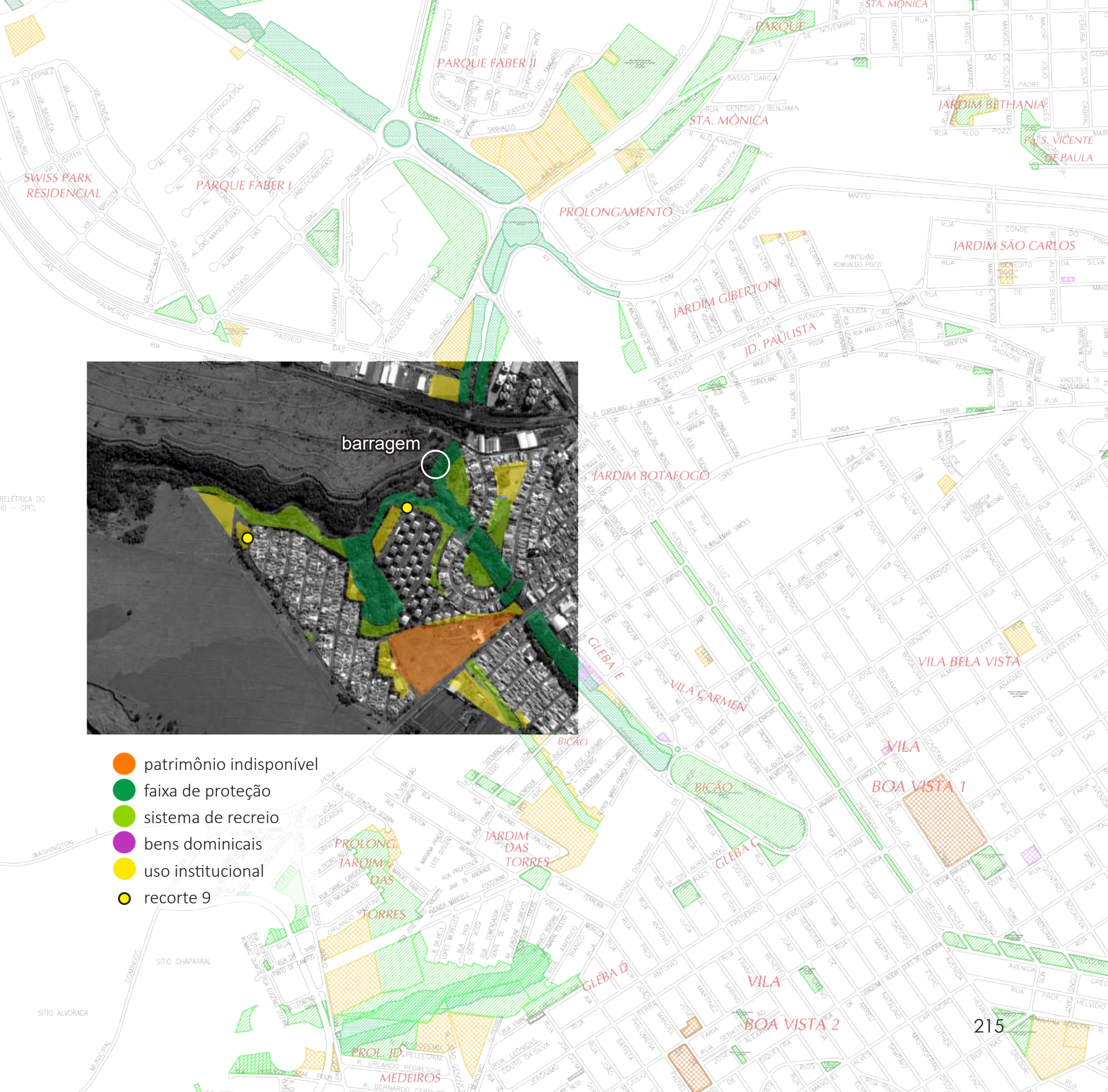




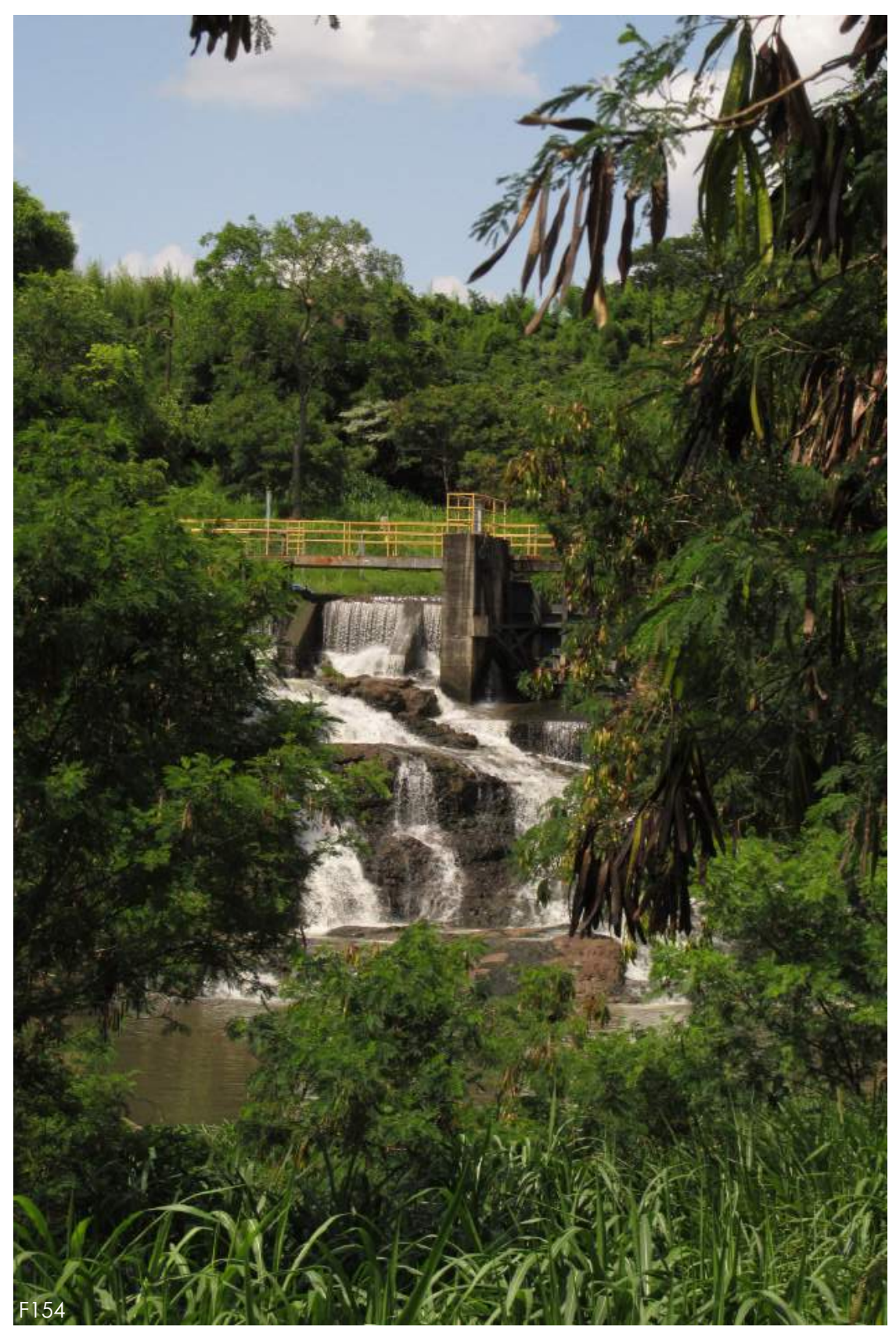



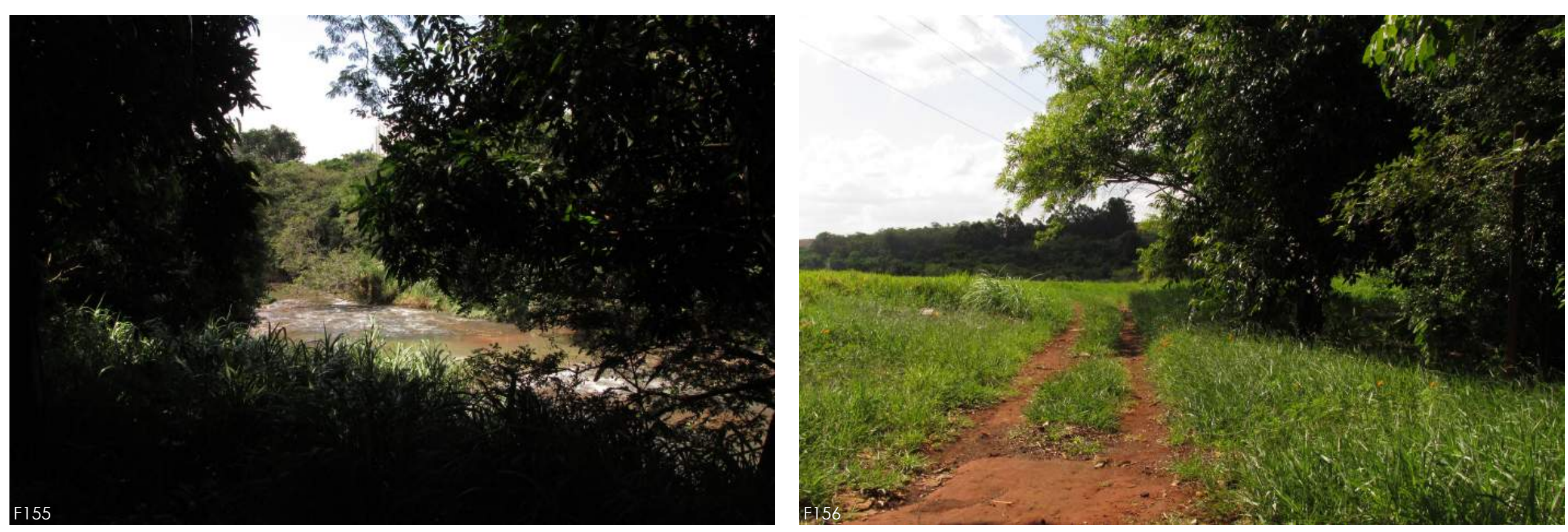


\section{CONSIDERAÇÕES FINAIS}

A noção de paisagem é tema discutido por várias disciplinas em consonância com seus repertórios, específicos de cada época. É possível que definições semelhantes coincidam entre alguns campos de acordo com a mentalidade vigente, embora seja frequente a divergência de abordagens.

Articulando reflexões presentes, sobretudo, na geografia, pode-se dizer que a paisagem transforma e é transformada pela sociedade humana e, nesse sentido, é construção cultural que, além de uma materialidade, refere-se a um conjunto de valores segundo os quais se interpreta o meio onde habita a sociedade. Segundo essa perspectiva, a paisagem traduz um modo de ver o mundo vinculado a uma época e seus valores, que definem concretamente e simbolicamente o território.

As contribuições da fenomenologia acrescentam que a paisagem é também a experiência resultante do contato direto entre ser humano e o mundo que antecede e suporta as elaborações científicas, constituídas por abstrações. A fruição da paisagem permite retomar o contato com uma base pré-existente, cujas manifestações ocorrem pelas frestas de um mundo construído e elaborado. Isso significa que a paisagem compreendida como experiência escapa aos esforços de controle do conhecimento consolidado por um discurso científico convencional que pretende abarcar o mundo enquanto totalidade. Segundo a perspectiva fenomenológica, a paisagem está presente naquilo que é efêmero e indeterminado; é um evento que existe somente em seu momento de realização e suas qualidades se tornam indisponíveis quando passam pela mediação da representação.

Propor uma definição sobre o que seria a paisagem para a Arquitetura da Paisagem consiste em tarefa complexa, pois esse campo lida essencialmente com o mundo vivido, que é constituído por interações permanentes e cambiantes entre o que há de objetivo e subjetivo na paisagem. Tendo em vista a multiplicidade da noção de paisagem, o arquiteto paisagista se depara com concepções historicamente consolidadas e com novas paisagens que se colocam no contexto da cidade contemporânea que geralmente não são reconhecidas 
pela cultura dominante. Pouco definidas, algumas paisagens se mantém invisíveis no cotidiano urbano, mesmo correspondendo à sua principal parte constituinte.

Ao observar o tema da paisagem através do campo projetual, identifica-se a necessidade de agenciar as distintas abordagens, o que tem sido feito por alguns profissionais da área como Bernard Lassus e James Corner. Entende-se que a elaboração de intervenções no território pela Arquitetura da Paisagem supõe confrontar aspectos objetivos (características físicas do território, como relevo, hidrografia, vegetação, tipos de uso), subjetivos (significados historicamente construídos ou identificados nas ações cotidianas e modos de representação) e experiências que se encontram entre essas duas dimensões.

O processo de projeto da paisagem deve reconhecer a existência de representações de uma cultura dominante, estando, ao mesmo tempo, atento àquilo que se mantém à margem e que aparentemente prescinde de função e significado, ou que não é objeto de interesse por parte de agentes produtores da cidade que se colocam em evidência. O processo de projeto deve ser capaz de identificar paisagens potenciais que passam despercebidas pelo olhar habitual, condicionado pelas interpretações hegemônicas.

Isso supõe captar o aspecto fugidio e intangível das paisagens de margem que, ao mesmo tempo em que provocam experiências efêmeras, dependem da presença permanente de uma base material original que, por mais que seja moldada pela ação humana, ainda se manifesta de forma independente das intenções de controle.

A identificação de um objeto de intervenção complexo, a paisagem, supõe uma estratégia projetual capaz de abarcar tal multiplicidade. Assim, esta pesquisa identifica a cartografia como estratégia metodológica que articula a dimensão histórica presente na paisagem, isto é, a sequência de ações que, vinculadas aos valores de uma época, determinaram sua configuração material e simbólica, à sua existência no presente, ou seja, as experiências desencadeadas pelo encontro ingênuo com o mundo.

Percorrendo as transformações que caracterizaram o fazer cartográfico ao longo do tempo, relacionadas aos vínculos constituídos ou dissolvidos entre ciência e arte, pode-se dizer que a cartografia é, ao mesmo tempo, representação, processo de leitura e de transformação da paisagem. Partindo das reflexões de Gilles Deleuze 
e Félix Guattari, autores compreendem a cartografia enquanto método, que supõe a inserção do pesquisador em seu campo, atento às distintas dinâmicas presentes e aos testemunhos de processos passados. O projeto paisagístico engendrado pela cartografia articula questões sistêmicas às singularidades de cada paisagem.

Esse modo de ler a paisagem foi experimentado em diversos momentos da história da arte, desde as vanguardas, especialmente pelo Dadaismo, até os artistas da Land Art. Esses movimentos artísticos exploraram a cartografia para além de sua tradicional concepção enquanto representação da superfície terrestre a partir de uma visão superior e instalaram um novo registro que distende a ideia original de representação cartográfica.

Considerando que a Arquitetura da Paisagem apresenta vínculos históricos com o discurso artístico e científico, esse aspecto expressivo da cartografia se mostra promissor para se pensar o processo de projeto. O contexto contemporâneo estabeleceu um modo de intervir no território que não se pauta mais em grandes projetos que dominam as paisagens e as transformam. As abordagens artísticas sobre a cidade contemporânea indicaram as bases para que o campo projetual apoiasse suas ações em um processo de conhecimento que imerge e experimenta as paisagens.

A cartografia enquanto método permite agenciar aspectos socioculturais, ambientais, políticos e econômicos, proporcionando um fazer projetual que não se apoia estritamente em uma visão de sobrevoo e não se limita a uma estrutura de diagnósticos e soluções. Essa estratégia de projeto leva em consideração a explicitação de paisagens, a quebra de leituras habituais, um dos fatores essenciais para a transformação de valores e de modos de ver e viver a paisagem e, portanto, a relação entre cidade e natureza.

O caminhar e a fotografia se colocam como operação e ferramenta que podem compor esse processo de conhecimento do território, sendo que, atreladas à linguagem poética, permitem o prolongamento de experiências passageiras que apresentam o potencial de ancorar diretrizes de projeto. Paisagens de margem geralmente não participam dos registros históricos e é com a frequentação pelo caminhar e pela fotografia que elas se tornam disponíveis. São essas paisagens que de fato compõem o cotidiano da cidade contemporânea, mais do que as representações da cultura dominante e é para elas que o projeto da paisagem deve voltar seu olhar. 
Para refletir acerca do projeto da paisagem no contexto contemporâneo, a relação entre natureza e cidade e, particularmente entre rios e cidade, se mostra representativa, pois torna patente a necessidade de articular aspectos múltiplos da paisagem. Não se trata de uma investigação que busca o retorno a um estado natural original do mundo. Busca, na verdade, apreender as relações estabelecidas entre o ser humano e suas práticas e uma base material pré-existente e os processos naturais que a caracterizam; em outras palavras, a apreensão das paisagens resultantes das interações entre fatores diversos que compõem o mundo vivido.

Este trabalho se voltou para a leitura da relação entre rios e cidade segundo o Método Cartográfico, articulando o processo histórico de constituição da paisagem às suas características no contexto contemporâneo e extrapolando os limites das abordagens estritamente ecológicas do projeto paisagístico. As noções da ecologia desempenham um importante papel nas reflexões sobre o projeto da paisagem, considerando os ambientes urbanos como participantes do funcionamento do ecossistema. Porém, entende-se que tal viés não é suficiente para se pensar o projeto em Arquitetura da Paisagem, tendo em vista a complexidade da questão.

Uma leitura historiográfica sobre a relação entre rios e cidade permitiu explicitar o modo como o planejamento urbano, as dinâmicas econômicas e a cultura dominante configuram a paisagem, entretanto, sem dar conta de todos os seus aspectos. A inserção do pesquisador no campo de estudo é essencial para revelar as paisagens de margem que não participam das narrativas históricas, mas que são expressão das relações cotidianas entre a cidade e seus rios.

Considerando o contexto da cidade de São Carlos, identificou-se um processo histórico que construiu predominantemente relações de conflito entre rede hídrica e cidade. Desde a origem da cidade, os cursos d'água foram gradualmente suprimidos da paisagem, seja por obras de canalização e tamponamento, seja por modos de construir a cidade que mantiveram esses elementos à margem dos processos urbanos. Uma mentalidade que relaciona a ideia de progresso ao controle da natureza pela técnica esteve presente em vários momentos do processo de urbanização de São Carlos, até que, no final do século XX o debate ambientalista ganhou visibilidade e participou do planejamento da cidade, objetivando transformar o conflito em congruência. 
Em conjunto a essa leitura historiográfica, realizou-se um estudo de campo, de modo a frequentar as paisagens que se manifestam nesses territórios relatados pelo olhar histórico e técnico. Trata-se de um ensaio metodológico que busca desvendar qualidades e gerar categorias durante o processo de frequentação.

A leitura que arremata esta pesquisa buscou acessar as paisagens caracterizadas pela indeterminação, ausentes nas narrativas históricas, mas fruto desse mesmo processo histórico. Buscou-se promover um ensaio sobre um potencial processo de projeto que acessa as qualidades da paisagem que geralmente estão ocultas pela indeterminação, dialogando com os significados construídos ao longo do tempo. A definição das categorias Paisagem Determinada e Paisagem Indeterminada consistiu em uma proposta de explicitar as paisagens que estão em constante transformação, de acordo com vários aspectos objetivos e subjetivos.

Assim, caminhar pelo território da bacia hidrográfica do córrego Monjolinho foi a atitude necessária para apreender os fenômenos que escapam aos significados dominantes, identificando manifestações que subvertem uma lógica global e especificam cada paisagem de margem. Trata-se de um movimento que permite a identificação de paisagens potenciais, articulando-as de modo a constituir um conjunto de espaços livres relevantes para se apreender a relação entre rios e cidade para além de seu aspecto de conflito.

As discussões realizadas em distintos campos disciplinares e épocas, que tiveram como foco a paisagem, deram suporte para que, no contexto contemporâneo, a Arquitetura da Paisagem fosse capaz de tratar do assunto de maneira ampla, abarcando as diversas dimensões que caracterizam a relação entre ser humano e mundo. Conforme argumenta Jean-Marc Besse, o arquiteto da paisagem seria o "operador da complexidade" (BESSE, 2014, p. 64) que agencia as distintas acepções do termo, concentrando sua reflexão e ação nos propósitos de intervenção no território.

O modo de conceber a contemporaneidade proposto por Deleuze e Guattari, que de certa forma permeia as reflexões de autores de diversos campos disciplinares, indica uma possível abordagem no campo da arquitetura da paisagem que concebe o projeto enquanto processo aberto, em constante criação, construído por múltiplos fatores e agentes. O papel do arquiteto da paisagem nessa realidade complexa seria identificar potencialidades e 
desconstruir leituras utilitaristas, sem a pretensão de controlar as maneiras pelas quais a paisagem é percebida, mas evidenciando o conteúdo poético do mundo vivido.

É necessário desenvolver estratégias metodológicas contemporâneas de projeto que promovam vínculos com as especificidades de cada contexto e que revelem paisagens ocultas pelos valores dominantes que interpretam o mundo. Aproximar-se do cotidiano e de seus praticantes, como defende Michel de Certeau, permite a revelação de outras lógicas e suas respectivas paisagens, ampliando as possibilidades projetuais. 0 processo de projeto que não se restringe à visão de sobrevoo e entra em contato com o que há de indeterminado, consegue captar a paisagem em sua multiplicidade, diversificando sua experiência. 


\section{REFERÊNCIAS BIBLIOGRÁFICAS}

AGOSTINHO, Larissa Drigo. O homem dos lobos: Deleuze, Guattari e a psicanálise. Revista Veritas. PUCRS: Porto Alegre, v. 62, n. 2, maio-ago. 2017, p. 377-406.

ALIATA, Fernando; SILVESTRI, Graciela. A paisagem como cifra de harmonia: relações entre cultura e natureza através do olhar paisagístico. Curitiba: Editora UFPR, 2008.

ALVAREZ, Johnny; PASSOS, Eduardo. Cartografar é habitar um território existencial. In PASSOS, Eduardo; KASTRUP, Virgínia; ESCÓSSIA, Liliana da. (Org.). Pistas do método da cartografia: pesquisa-intervenção e produção de subjetividade. Porto Alegre: Sulina, 2015.

ANELLI, Renato Luiz Sobral Recuperação de cursos d'água e nascentes associada à revisão da ocupação viária estrutural de Fundo de Vale em São Carlos/SP (2001-2005). In: APP Urbana 2007 - Seminário Nacional sobre o tratamento de áreas de preservação permanente em meio urbano e restrições ambientais ao parcelamento do solo. São Paulo: FAU USP, 2007.

Sistema Viário e Recuperação de Recursos Hídricos (córregos e nascentes) em São Carlos/SP. In: Águas Urbanas - I Seminário Nacional Sobre Regeneração Ambiental de Cidades. Rio de Janeiro, 2005.

BAGLIANI, Francesca (Org.) Paesaggio: un'esperienza multiculturle: scritti di Bernard Lassus. Edizioni Kappa: Roma, 2010.

BARTALINI, Vladimir. A paisagem em arquitetura e urbanismo: remontar às "nascentes" como opção metodológica. Paisagem e Ambiente, São Paulo, n. 32, p. 69-81, dez. 2013a. Disponível em <https://www.revistas.usp.br/paam/ article/view/88080>. Acesso em 14 ago. 2017. 
A trama capilar das águas na visão cotidiana da paisagem. Revista USP, São Paulo, n. 70, p. 88-97, junho/ agosto 2006. Disponível em <https://www.revistas.usp.br/revusp/article/view/13534/15352> Acesso em 14 ago. 2017.

Natureza, paisagem e cidade. Revista do Programa de Pós-Graduação em Arquitetura e Urbanismo da FAUUSP, São Paulo, v. 20, n. 33, p. 36-48, junho 2013b. Disponível em <https://www.revistas.usp.br/posfau/ article/view/80919>. Acesso em 14 ago. 2017.

Os córregos ocultos e a rede de espaços públicos urbanos. Arquitextos, São Paulo, n. 106.01, maio 2009. Disponível em <http://www.vitruvius.com.br/revistas/read/arquitextos/09.106/64> acesso em 8 set. 2015.

BARTHES, Roland. A câmara clara. Lisboa: Edições 70, 1980.

BERQUE, Augustin. Paisagem-marca, paisagem-matriz: elementos da problemática para uma geografia cultural. In CORRÊA, Roberto Lobato; ROSENDAHL, Zeny. Paisagem, tempo e cultura. Rio de Janeiro: EDUERJ, 2004.

Paysage, milieu, histoire. In BERQUE, A. (org.) Cinq propositions pour une théorie du paysage. Mayenne: Champ Vallon, 1994.

BESSE, Jean-Marc. O gosto do mundo: exercícios de paisagem. Rio de Janeiro: Eduerj: 2014.

Ver a terra: seis ensaios sobre a paisagem e a geografia. São Paulo: Perspectiva, 2006.

BISINOTTO, Dagmar A. Evolução urbana de São Carlos. Trabalho de iniciação científica. São Carlos: EESC/USP, 1988.

BORTOLUCCI, Maria Ângela P. C. S. Moradias urbanas construídas em São Carlos no período cafeeiro. Tese de doutorado. São Paulo: FAUUSP, 1991.

BRESCIANI, Maria S. Dimensões do estar no mundo/cidades: o público, o privado, o íntimo. In BRITTO, Fabiana D.; 
JACQUES, Paola B. (org.). Corpocidade: gestos urbanos. Salvador: Edufba, 2017.

CALDEIRA, Teresa P. do R. Cidade de muros: crime segregação e cidadania em São Paulo. São Paulo: Ed. 34; Edusp, 2000.

CARERI, Francesco. Walkscapes: o caminhar como prática estética. São Paulo: editora G. Gili, 2013.

Caminhar e parar. São Paulo: Gustavo Gili, 2017.

CARVALHO, Beatriz F. R. Caminhar na cidade: experiência e representação nos caminhares de Richard Long e Francis Alÿs; depoimentos de uma pesquisa poética. Dissertação de mestrado. São Paulo: FAUUSP, 2007.

CERTEAU. Michel de (1980). A invenção do cotidiano: artes de fazer. Petrópolis: Editora Vozes, 2007.

CLAVAL, Paul. A geografia cultural. Florianópolis: Ed. UFSC, 2001.

CLÉMENT, G. Manifeste du Tiers Paysage. 2004. Disponível em <http://www.gillesclement.com/fichiers/_ tierspaypublications_92045_manifeste_du_tiers_paysage.pdf>

CORNER, James. Ecology and landscape as agents of creativity. In: THOMPSON, George F.; STEINER, Frederick R. (Orgs.). Ecological design and planning. New York: John Wiley, 1997.

Eidetic operations and new landscapes. In: CORNER, James (Org.). Recovering Landscape: essays in contemporary landscape architecture. New York: Princeton Architectural Press, 1999.

The agency of mapping. In COSGROVE, Denis (Org.). Mappings. London: Reaktion Books, 1999.

COSGROVE, Denis. A geografia está em toda parte: cultura e simbolismo nas paisagens humanas. In CORRÊA, Roberto Lobato; ROSENDAHL, Zeny. Paisagem, tempo e cultura. Rio de Janeiro : EDUERJ, 2004.

. Introduction: mapping meaning. In COSGROVE, Denis (Org.). Mappings. London: Reaktion Books, 1999. 
Liminal geometry and elemental landscape: construction and representation. In CORNER, James (Org.). Recovering landscape: essays in contemporary landscape architecture. New York: Princeton Architectural Press, 1999.

COSTA, Lucia Maria Sá Antunes (Org.). Rios e paisagens urbanas em cidades brasileiras. Rio de Janeiro : Viana \& Mosle, 2006.

COSTA, Luiz Augusto Maia. O ideário urbano paulista na virada do século: o engenheiro Theodoro Sampaio e as questões territoriais e urbanas modernas (1886-1903). São Carlos: Rima, 2003.

CULLEN, Gordon (1961). Paisagem urbana. Lisboa: Edições 70, 2002.

DARDEL, Eric (1952). O homem e a terra: natureza da realidade geográfica. São Paulo: Perspectiva, 2011.

DARDOT, Pierre; LAVAL, Christian. A nova razão do mundo. São Paulo: Boitempo, 2016.

DELEUZE, Gilles; GUATTARI, Félix (1980). Mil Platôs - vol. 1. São Paulo: Editora 34, 1995.

DEVESCOVI, Regina C. B. Urbanização e acumulação: um estudo sobre a cidade de São Carlos. São Carlos: UFSCar, 1987.

DIDI-HUBERMAN, Georges. Casacas. São Paulo: Editora 34, 2017.

. Atlas ou a gaia ciência inquieta. Lisboa : KKYM, 2013.

DONOSO, Verônica Donoso. A paisagem e os sistemas de espaços livres na urbanização contemporânea do interior paulista: estudo de caso da área entre São Carlos, Araraquara e Ribeirão Preto. Dissertação de Mestrado. São Paulo: FAUUSP, 2011.

FEITOSA, Jardel P. Industrialização e urbanização em São Carlos nas décadas de 1930 a 1960. Dissertação de mestrado. São Carlos: IAUUSP, 2015. 
FOUCAULT, Michel (1975). Vigiar e punir: nascimento da prisão. Petrópolis: Editora Vozes, 2014.

FRANCO, Fernando M. A construção do caminho: a estruturação da metrópole pela conformação técnica das várzeas e planícies fluviais da Bacia de São Paulo. Tese de Doutorado. São Paulo: FAU USP, 2005.

GORSKI, Maria Cecília B. Rios e cidades: ruptura e reconciliação. São Paulo: Senac, 2010.

HERZOG, Cecília P. Cidade para todos. Rio de Janeiro: Mauad X: Inverde, 2013.

HERZOG, Cecília Polacow; ROSA, Lourdes Zunino. Infraestrutura Verde: Sustentabilidade e resiliência para a paisagem urbana. Revista LABVERDE, São Paulo, n. 1, p. 92-115, set. 2010. Disponível em: <https://www.revistas. usp.br/revistalabverde/article/view/61281/64217>. Acesso em 14 ago. 2017.

HOUGH, Michael (1984). Naturaleza y ciudad. Barcelona: GG, 1998.

JACOBS, Jane (1961). Morte e vida de grandes cidades. São Paulo: WMF Martins Fontes, 2013.

JACQUES, P. B.; BRITTO, F.D.; DRUMMOND, W. (Org.). Experiências Metodológicas para compreensão da complexidade da cidade contemporânea. Salvador: EDUFBA, 2015.

JACQUES, Paola Berenstein. Errâncias urbanas: a arte de andar pela cidade. Arqtexto, Porto Alegre, n. 7, p. 16- 25, 2005.

. O grande jogo do caminhar. In: CARERI, Francesco. Walkscapes: o caminhar como prática estética. São Paulo: editora G. Gili, 2013.

KASTRUP, Virgínia. O funcionamento da atenção no trabalho do cartógrafo. In PASSOS, Eduardo; KASTRUP, Virgínia; ESCÓSSIA, Liliana da. (Org.). Pistas do método da cartografia: pesquisa-intervenção e produção de subjetividade. Porto Alegre: Sulina, 2015.

LASSUS, Bernard. L'obligation de l'invention: du paysage aux ambiances successives. In BERQUE, A. (org.) Cinq 
propositions pour une théorie du paysage. Mayenne: Champ Vallon, 1994.

LEFEBVRE, Henri (1970). A revolução urbana. Belo Horizonte: Editora UFMG, 2002.

LIMA, Renata. P. Limites da legislação e do (des) controle da expansão urbana: São Carlos (1857-1977). São Carlos: EduFSCar, 2008.

LYNCH, Kevin (1960). A imagem da cidade. São Paulo: Martins Fontes, 2011.

MACEDO, Silvio S. e SAKATA, Francine G. Parques Urbanos no Brasil. São Paulo: EDUSP, 2003.

MACEDO, Silvio S. et al. Considerações preliminares sobre o sistema de espaços livres e a constituição da esfera pública. In TÂNGARI, Vera Regina; ANDRADE, Rubens de; SCHLEE, Mônica Bahia (Orgs.). Sistema de espaços livres: o cotidiano, apropriações e ausências. Rio de Janeiro: PROARQ, 2009, p. 60-83.

MACEDO, Silvio S. Lugares, espaços livres e contemporaneidade - características dos sistemas de espaços livres das cidades brasileiras contemporâneas. In RHEINGANTZ, Paulo Afonso; PEDRO, Rosa Maria Leite Ribeiro (Orgs.). Qualidade do lugar e a cultura contemporânea. Controvérsias e ressonâncias em coletivos urbanos. Rio de Janeiro, PROARQ FAU-UFRJ, 2012, p. 145-152.

MADERUELO, Javier. Maneras de ver el mundo: de la cartografía al paisaje. In MADERUELO, Javier (Org.). Paisaje y territorio. Madrid: Abada, 2008.

MARICATO, Ermínia. As ideias fora do lugar e o lugar fora das ideias: planejamento urbano no Brasil. In ARANTES, O.; VAINER, C.; MARICATO, E. A cidade do pensamento único: desmanchando consensos. São Paulo: Editora Vozes, 2000.

MARX, Murillo. Cidade no Brasil, Terra de Quem? São Paulo: Edusp/Nobel, 1991.

MCHARG, Ian (1969). Design with Nature. Jonh Wiley \& Sons Inc., 1992. 
MERLEAU-PONTY, Maurice (1945). Fenomenologia da percepção. São Paulo: Martins Fontes, 1994.

O olho e o espírito. São Paulo: Cosac Naify, 2013.

NOGUÉ, Joan. Al margen: los paisajes que no vemos. In MADERUELO, Javier (Org.). Paisaje y territorio. Madrid: Abada, 2008.

NORBERG-SCHULTZ, Christian (1976). O fenômeno do lugar. In NESBITT, Kate (Org.). Uma nova agenda para a arquitetura: antologia teórica (1965 - 1995). São Paulo: Cosac Naify, 2013.

OSEKI, Jorge Hajime; ESTEVAM, Adriano Ricardo. A fluvialidade em rios paulistas. In: COSTA, Lucia Maria Sá Antunes (Org.). Rios e paisagens urbanas em cidades brasileiras. Rio de Janeiro : Viana \& Mosle, 2006.

PASSOS, Eduardo; KASTRUP, Virgínia; ESCÓSSIA, Liliana da. (Org.). Pistas do método da cartografia: pesquisaintervenção e produção de subjetividade. Porto Alegre: Sulina, 2015.

PELLEGRINO, Paulo R. M. et al. A paisagem da borda: uma estratégia para a condução das águas, da biodiversidade e das pessoas. In COSTA, Lucia Maria Sá Antunes (Org.). Rios e paisagens urbanas em cidades brasileiras. Rio de Janeiro: Viana \& Mosley: PROURB, 2006, p. 57-76.

PERES, Renata. B. O Planejamento Regional e Urbano e a Questão Ambiental: Análise da relação entre o Plano de Bacia Hidrográfica Tietê-Jacaré e os Planos Diretores Municipais de Araraquara e São Carlos, SP. Tese de Doutorado. São Carlos: UFSCAR, 2012.

PROJETO ELETROMEMÓRIA. Relatório da 5 a expedição realizada pelos pesquisadores do Projeto Eletromemória, entre 21 e 24 de julho de 2014, na qual foram visitadas as usinas de Corumbataí, Capão Preto, Monjolinho, LiaMarmelos e Isabel. n.d.

ROGER, Alain. Breve tratado del paisaje. Madrid: Biblioteca Nueva, 2007. 
ROLNIK, Raquel. Guerra dos lugares: a colonização da terra e da moradia na era das finanças. São Paulo: Boitempo, 2016.

ROLNIK, Suely. Cartografia sentimental: transformações contemporâneas do desejo. Porto Alegre: Sulina; Editora da UFRGS, 2006.

ROMAGNOLI, Roberta C. A cartografia e a relação pesquisa e vida. Psicologia \& Sociedade, Belo Horizonte, v. 21 (2), $166-173,2009$.

SANTOS, Milton. A natureza do espaço: técnica e tempo, razão e emoção. São Paulo: EDUSP, 2002.

SÃO CARLOS. Plano Municipal de Saneamento de São Carlos. Relatório 05. PMSC. São Carlos, 2012.

SÃO CARLOS/SHS Ltda. Plano Diretor de Drenagem Urbana Ambientalmente Sustentável do Município de São Carlos. Volume 1- Bases cartográficas e formulação de cenários, diagnóstico e prognóstico. Contrato no 87/09PMSC/SHS Consultoria e Projetos de Engenharia Ltda. São Carlos, 2011.

SÃO CARLOS/FUSP. Revisão do Plano Diretor do Município de São Carlos. Produto I. Leitura Técnica do Município. Contrato nำ40/11- PMSC/FUSP. São Carlos, 2011.

SAUER, Carl. A morfologia da paisagem. In CORRÊA, Roberto Lobato; ROSENDAHL, Zeny. Paisagem, tempo e cultura. Rio de Janeiro: EDUERJ, 2004.

SCHENK, Luciana B. M. ; PERES, R. B. Agentes Produtores e Espaços Livres na Forma Urbana de São Carlos, SP. In: Forma Urbana Contemporânea Brasileira: Espaços Livres, Produção e Apropriação. IX Colóquio QUAPÁ- SEL, Vitória, 2014.

SCHENK, Luciana B. M.; PERES, Renata. B.; FANTIN, Marcel. A Revisão do Plano Diretor da Cidade de São Carlos e as Novas Formas Urbanas em Curso. In: Forma Urbana Contemporânea Brasileira: Espaços Livres, Produção e Apropriação. X Colóquio QUAPÁ- SEL, Brasília, 2015. 
SCHENK, Luciana. B. M. Arquitetura da paisagem: entre o Pinturesco, Olmsted e o Moderno. Tese de Doutorado. São Carlos: EESC/USP, 2008.

SCHUTZER, José G. Cidade e meio ambiente. São Paulo: Edusp, 2012.

SMITHSON, Robert. Um passeio pelos monumentos de Passaic, Nova Jersey. Arte \& Ensaios, Rio de Janeiro: Programa de Pós-Graduação em Artes Visuais, Escola de Belas Artes, UFRJ, n. 19, p. 162-167, dez. 2009. Tradução do texto: "The Monuments of Passaic", Artforum, December 1967, p.48

SPIRN, Anne W (1984). O jardim de Granito. São Paulo: Edusp, 1995.

The language of landscape. New Haven, Conn.: Yale University Press, 1998.

STRAUS, Erwin (1935). Le sens des sens. Contribution à l'étude des fondements de la psychologie. Grenoble: Jérôme Millon, 2000.

TIBERGHIEN, Gilles A. A cidade nômade. In: CARERI, Francesco (2002). Walkscapes: o caminhar como prática estética. São Paulo: editora G. Gili, 2013.

WYLIE, John. Landscape. New York: Routledge, 2007. 